PAULO ALAS

O FENÔMENO DOS SUPERCONDOMÍNIOS:

verticalização na metrópole paulistana

no início do século XXI

São Paulo

2013 

PAULO ALAS

\section{O FENÔMENO DOS SUPERCONDOMÍNIOS:}

verticalização na metrópole paulistana no início do século XXI

Dissertação apresentada à Faculdade de Arquitetura e Urbanismo da Universidade de São Paulo, para obtenção do título de Mestre em Arquitetura e Urbanismo.

Área de Concentração: Paisagem e Ambiente

Orientador: Silvio Soares Macedo

São Paulo/SP

2013

EXEMPLAR REVISADO E ALTERADO EM RELAÇÃO À VERSÃO ORIGINAL, SOB RESPONSABILIDADE DO AUTOR E ANUÊNCIA DO ORIENTADOR. 
AUTORIZO A REPRODUÇÃO E DIVULGAÇÃO TOTAL E PARCIAL DESTE TRABALHO, POR QUALQUER MEIO CONVENCIONAL OU ELETRÔNICO, PARA FINS DE ESTUDO E PESQUISA, DESDE QUE CITADA A FONTE.

Email autor:paulo_alas@yahoo.com

A323 Alas, Paulo
O fenômeno dos supercondomínios: verticalização na metrópole
paulistana no início do século XXI / Paulo Alas - São Paulo, 2013.
166p: II
.$s ;$
Dissertação (Mestrado - Área de Concentração: Paisagem e
Ambiente) - FAUUSP
Orientador: Silvio Soares Macedo
1. Mercado Imobiliário - São Paulo (SP) 2. Desenho urbano. 3.
Habitação. 4.Condomínio. 5. Condomínios Fechados. 6. Uso do solo.
CDU 332.72




\section{FOLHA DE APROVAÇÃO}

ALAS, PAULO. O fenômeno dos supercondomínios: verticalização na metrópole paulistana no início do século XXI. Dissertação apresentada à Faculdade de Arquitetura e Urbanismo da Universidade de São Paulo, para obtenção do título de Mestre em Arquitetura e Urbanismo.

Orientador Dr. Silvio Soares Macedo.

Aprovado em:

Banca examinadora

\begin{tabular}{llcl} 
Prof. $\mathrm{Dr}$ & Instituição: & Julgamento: & Ass: \\
\hline Prof. $\mathrm{Dr}$ & Instituição: & Julgamento: & Ass: \\
\hline Prof. $\mathrm{Dr}$ & Instituição: & Julgamento: & Ass:
\end{tabular}




\section{AGRADECIMENTOS}

Agradeço ao meu orientador, Prof. Dr. Silvio Soares Macedo, pelo apoio, pela confiança, e pela liberdade que me foram dados ao longo do desenvolvimento deste trabalho. Pela paciência e pela humildade durante as discussões calorosas, encorajando-me e me mantendo sempre instigado. Pelo acolhimento que me ofereceu, desde a graduação. Seu comprometimento com o ensino, com os alunos e com a "causa paisagística" será sempre motivo de orgulho para mim.

Aos professores Dra. Raquel Rolnik e Dr. Manoel Lemes da Silva Neto, pelos valiosos comentários e sugestões apresentados durante a banca de qualificação e aos professores Dr. Jonathas Magalhães Pereira da Silva e Dr. Eugenio Fernandes Queiroga, pelos valiosos comentários e sugestões apresentados durante a banca final. Aos professores Dra. Denise Dantas, Dr. Paulo Eduardo Fonseca de Campos e Dra. Cibele Haddad Taralli, de quem fui estagiário PAE, experiência esta que complementou a minha formação.

Ao Governo Holandês, por poder participar do Netherlands Fellowship Programme (NFP) e aos colegas e professores do Institute of Housing and Urban Development Studies - IHS, Universidade Erasmus, Rotterdam. À FAPESP, pela bolsa de estudos que recebi, ainda que por um breve período, para a realização deste mestrado. Ao Lincoln Institute of Land Policy, pela bolsa de estudos para finalização Tesis de Maestria, e aos economistas Dr. Ciro Biderman e Dr. Martim O. Smolka, membros da banca de avaliação do Lincoln, dos quais recebi importantes contribuições. 
À incorporadora e construtora Plano e Plano, em especial ao Luiz Armando Fairbanks de Sá e ao Rodrigo Uchoa Luna, pelas oportunidades que me foram dadas enquanto fui trainee e, posteriormente, coordenador de incorporação. Esta experiência foi de fundamental importância não apenas para a escolha do tema deste trabalho, mas para a minha formação como arquiteto. À Ana Cristina Nogueira, coordenadora de inteligência de mercado, e hoje amiga, pelas ajudas e por dividir sua visão aguçada por anos de trabalho no mercado imobiliário. À equipe da Secretaria Municipal de Habitação, da Prefeitura Municipal de São Paulo, onde trabalhei por um breve período, e em especial à Arq. Maria Lúcia Tanabe e ao Arq. Saulo Medeiros, pelas horas despendidas discutindo a legislação comigo. E, recentemente, à equipe do Departamento de Produção Habitacional, da Secretária Nacional de Habitação do Ministério das Cidades, onde trabalho. Em especial a Diretora do DHAB, Eng. Maria do Carmo Avesani, pelo suporte e compreensão nos meses finais da redação da dissertação.

Ao QUAPÁ, pelas portas sempre abertas e, é claro, pelas imagens cedidas, à ABECIP e à EMBRAESP pelas informações e dados disponibilizados.

Aos amigos que me ouviram, incansavelmente, discutir este trabalho. Em especial ao Arq. Fernando Renberg e à Arq. Fernanda Cristina Marques e ao Geógrafo Bruno Cruz.

Por fim, à minha família, Ofelia e Celia, pelo entusiasmo que mantiveram nas infindáveis leituras comentadas que realizaram, muito obrigado. 


\section{RESUMO}

ALAS, PAULO. O fenômeno dos supercondomínios: verticalização na metrópole paulistana no início do século XXI. 2013. Dissertação (mestrado) - Faculdade de Arquitetura e Urbanismo, Universidade de São Paulo, São Paulo, 2013.

Nesta dissertação analisa-se a ascensão do modelo de empreendimento residencial vertical com ampla oferta de espaços de lazer em condomínio - aqui denominado supercondomínio - ao longo da década de 2000, na Região Metropolitana de São Paulo. Não se restringindo às explicações mercadológicas, justificadas pelo estabelecimento de uma suposta "nova forma de morar", o trabalho busca, por meio da caracterização da produção, exposição da lógica financeira e análise do marco regulatório edilício, demonstrar como a reestruturação do processo produtivo no contexto do Boom imobiliário, levou à revisão das estratégias de atuação dos promotores imobiliários, consolidando os supercondomínios como um modelo de empreendimento a ser seguido.

Palavras-chave: 1. Mercado Imobiliário 2.Desenho urbano. 3.Habitação. 4.Verticalização.

5.Condomínios Fechados. 6.Uso do solo. 


\section{ABSTRACT}

ALAS, PAULO. The Supercondominium phenomenon: verticalization in São Paulo metropolis at the beginning of the XXI century. 2013. Dissertion (mestrado) - Faculdade de Arquitetura e Urbanismo, Universidade de São Paulo, São Paulo, 2013.

This dissertation investigates the ascension of multifamily building that offers a wide range of leisure facilities in condominium - here denominated supercondominium - in the São Paulo Metropolitan Area, during the 2000s. Looking beyond mere sales arguments, based in the establishment of a supposed "new way of living," this work seeks through the characterization of the housing production, presentation of the financial logic and the analysis of the building regulatory framework, to demonstrate how the revision of the developers strategies, due the restructuring of the real estate production process during the housing Boom, consolidated the supercondominium as a new model to be pursued.

Keywords: 1.Real estate. 2.Urban design. 3.Housing. 4.Verticalization. 5.Condominium. 6.Land use. 


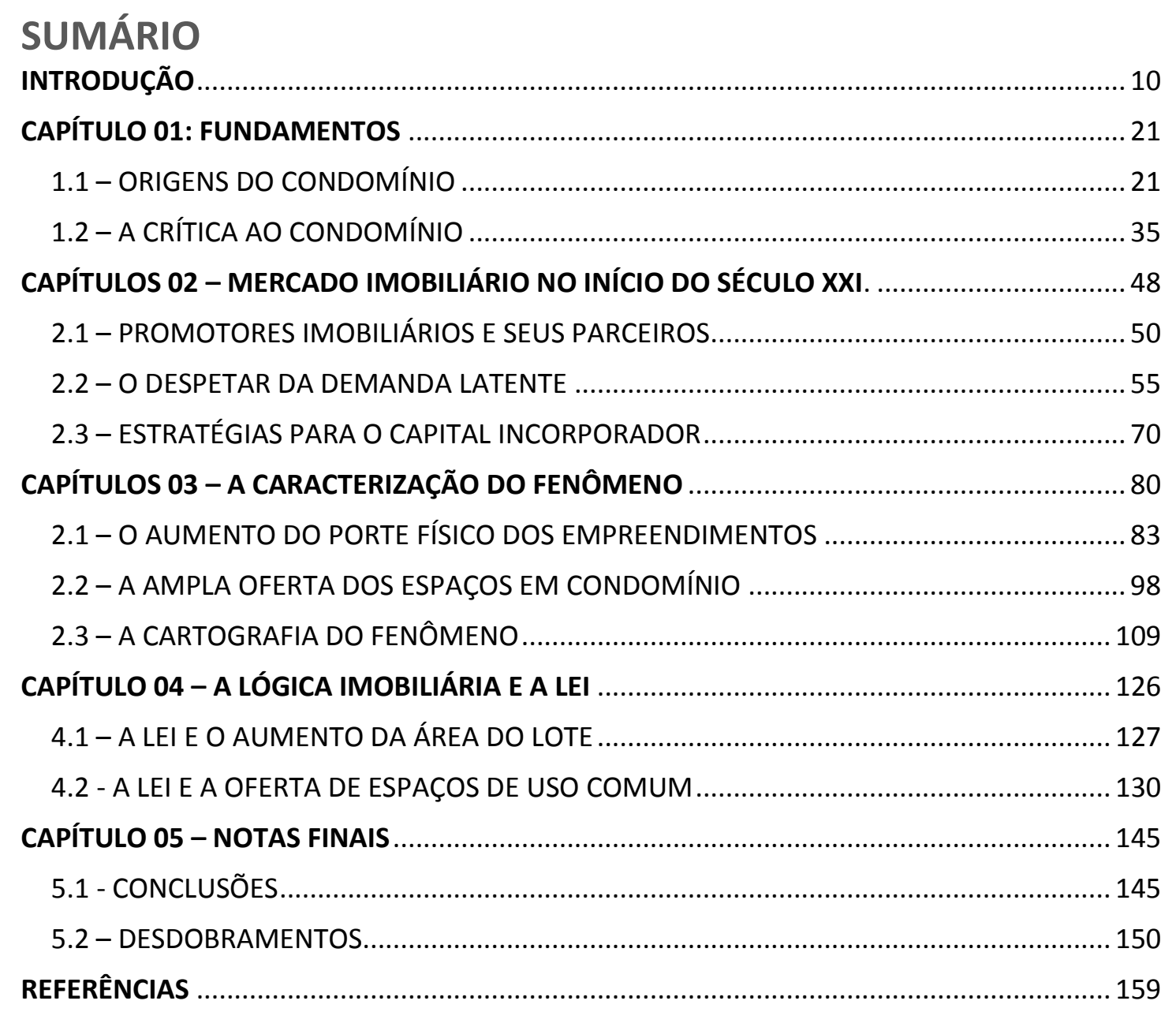




\section{APRESENTAÇÃO}

If you want to understand a development, it is no good standing outside the process; you have to wade into it. You have to allow yourself to be developed by the developments. From the outside, you see only the movements: what stands still, what shifts, what disappears. From the inside, you detect the transformations: what direction things are going in, what is changing and what new things are emerging ${ }^{1}$.

\section{Arjen Mulder}

Após a graduação, trabalhei cerca de dois anos desenvolvendo projetos em um escritório de paisagismo, sobretudo residenciais. Em parceria com importantes escritórios de arquitetura - Bernardes Jacobsen, Isay Weinfed, e Marcio Kogan - conheci o que acredito ser o melhor da produção arquitetônica contemporânea no Brasil (do ponto de vista formal), oculta atrás de grandes muros ou loteamentos fechados. Atendendo ao público de "altíssimo padrão", a prática se assemelhava à minha formação: não havia limites econômicos e as restrições legais eram pouco significativas.

A experiência seguinte foi no chamado "mercado imobiliário". Ouvi severas críticas à sua produção durante minha formação, mas curiosamente este era um agente muito pouco conhecido, apesar do seu protagonismo na (re)produção do espaço urbano. Naquele momento a estética neoclássica estava de moda em São Paulo e frequentemente escondia

\footnotetext{
${ }^{1}$ MULDER, 2002, p.7.
} 
soluções projetuais mal resolvidas. Para mim, a lógica deste desconhecido me fascinava, e o produto duvidoso só aumentava o meu fascínio. Em pleno "boom imobiliário", fui trainee na Incorporadora líder do setor. Para minha surpresa, fui encaminhado para uma joint-venture focada no segmento econômico, onde assisti na primeira fila os efeitos da crise imobiliária de 2008 e do plano habitacional Minha Casa Minha Vida. O dia-a-dia mostrava que o projeto de arquitetura era o resultado de uma equação complexa: interesses divergentes, limitações econômicas, jurídicas e financeiras. $\mathrm{O}$ arquiteto projetista tinha muito pouco da liberdade formal que eu havia conhecido na faculdade e no emprego anterior; as decisões de projeto eram justificadas e aprovadas somente depois de traduzidas em números e examinados em planilhas de viabilidade econômica.

Contraditoriamente, foi o conhecimento da "lógica do mercado", subestimado em minha formação, que me permitiu uma leitura mais clara da forma urbana produzida. É também o conhecimento desta lógica que me faz pensar sobre o papel periférico que tem sido desempenhado pelos arquitetos, teóricos, planejadores ou projetistas, na orientação do desenho urbano, questionamento que me motivou a desenvolver o trabalho a seguir. 


\section{INTRODUÇÃO}

Apontar o compromisso dos promotores imobiliários com o lucro tem sido uma conclusão recorrente no meio acadêmico para finalizar a discussão sobre a lógica morfológica da produção imobiliária, quando poderia ser apenas o seu início. Ainda que o lucro seja o objetivo maior da atividade imobiliária ${ }^{2}$ privada, a resposta formal-espacial para a obtenção deste lucro não é constante no espaço e no tempo. Bastaria uma rápida comparação da produção imobiliária atual entre metrópoles vizinhas como São Paulo, Buenos Aires e Bogotá, para verificar diferenças nos padrões de ocupação do lote, porte dos edifícios e estrutura dos espaços livres de uso comum, gerando diferentes níveis de inserção e interação dos empreendimentos com a cidade, ainda que submetidos à lógica valorização do capital incorporador. Isto ocorre pois, se por um lado a forma escolhida deve atender às necessidades do capital imobiliário, por outro está restrita às dinâmicas econômicas, sociais, culturais, tecnológicas.. e, sobretudo legais que operam sobre um determinado território. O capital imobiliário compõe e está submetido a este contexto. Para a escolha da forma ótima, o promotor imobiliário faz uma leitura das dinâmicas, traduzindo-as em oportunidades formal-espaciais, que são equacionadas para a maximização do lucro. Inversamente, o estudo da ascensão ou decadência de modelos formais específicos revela quais oportunidades formal-espaciais que são oferecidos ao capital imobiliário, ponto de partida desta análise.

\footnotetext{
${ }^{2}$ Como exceção, pode-se citar a produção subsidiada ou promovida pelo Estado, que faz parte da produção imobiliária e do mercado imobiliário, mas não está comprometida com o lucro.
} 
Na primeira década do sec. XXI, o Brasil viveu o chamado Boom imobiliário, período no qual a indústria imobiliária se fortaleceu, amplamente apoiada na retomada de uma política de crédito habitacional. A produção imobiliária, que por décadas havia se restringido às classes mais abastadas menos dependentes dos instrumentos de financiamento - tornou-se acessível a uma classe média ávida pela sonhada casa própria. O súbito aumento da demanda habitacional disponível exigiu uma rápida reestruturação da indústria imobiliária, adequando a produção ao seu novo público e, principalmente, a escala que ele exigia. As grandes cidades brasileiras viram o número de unidades habitacionais lançadas crescer vertiginosamente. Um marco desta transição foi o salto numérico observado entre os anos de 2006 e 2007, quando na Região Metropolitana de São Paulo (RMSP), centro do Boom, o número de unidades habitacionais lançadas em empreendimentos residenciais multifamiliares verticais aumentou de 31.839 para $54.822^{3}$, estabilizando-se em um novo patamar durante os anos seguintes.

Neste percurso, algumas dinâmicas físico-espaciais imobiliárias surgiram ou foram acentuadas, destacando-se: a expansão do perímetro de atuação do mercado imobiliário formal, com a intensificação da participação de bairros e municípios periféricos, paralela à redução da participação dos tradicionais bairros de elite; a diminuição da área privativa média dos apartamentos e a "comoditização" dos apartamentos e torres; o aumento do porte dos empreendimentos, em tamanho de lote e número de torres e sobretudo, a consolidação dos espaços de uso comum como atributo de distinção entre os

\footnotetext{
${ }^{3}$ Dados trabalhados pelo autor. FONTE: Base EMBRAESP.

${ }^{4}$ Freqüentemente empregado pelo marketing, o termo refere-se ao processo pelo qual os produtos oferecidos pelo mercado perdem a diferenciação entre uns e outros, aproximando-se à commodities. Para os bens considerados commodities, o único parâmetro de comparação utilizado pelo comprador é o preço, o que aumenta a concorrência e reduz as margens de lucro.
} 
empreendimentos. Dinâmicas que juntas apontam para a ascensão de um modelo específico de empreendimento residencial vertical multifamiliar - aqui chamados de supercondomínios - face mais evidente e controversa da produção imobiliária atual.

Popularmente chamados de "condomínios clube" ou "condomínios parque", caracterizam-se junto ao público pela ampla oferta de equipamentos de lazer nas áreas de uso comum. Ao programa básico usual - salão de festas, piscina e playground - adicionaram-se nas áreas internas, salão infantil e adulto, espaço gourmet, lounge, espaço mulher, espaço pet, garage band, atelier, "brinquedoteca", etc., interligadas por um extenso programa de espaços livres de lazer e circulação, como piscinas adulto e infantil, prainha, biribol, fontes, solarium, pomar, "redário", pet trail, etc., em combinações que ultrapassaram mais de 50 "itens de lazer" nos empreendimentos de maior porte ${ }^{5}$. Ainda que a ampla oferta de áreas de uso comum tenha sua origem em empreendimentos anteriores, a exemplo do Edifício Bretagne (1951) no bairro de HIgienópolis, marco da produção imobiliária na década de 1950 , os desafios que a produção presente traz residem na escala que o fenômeno alcançou.

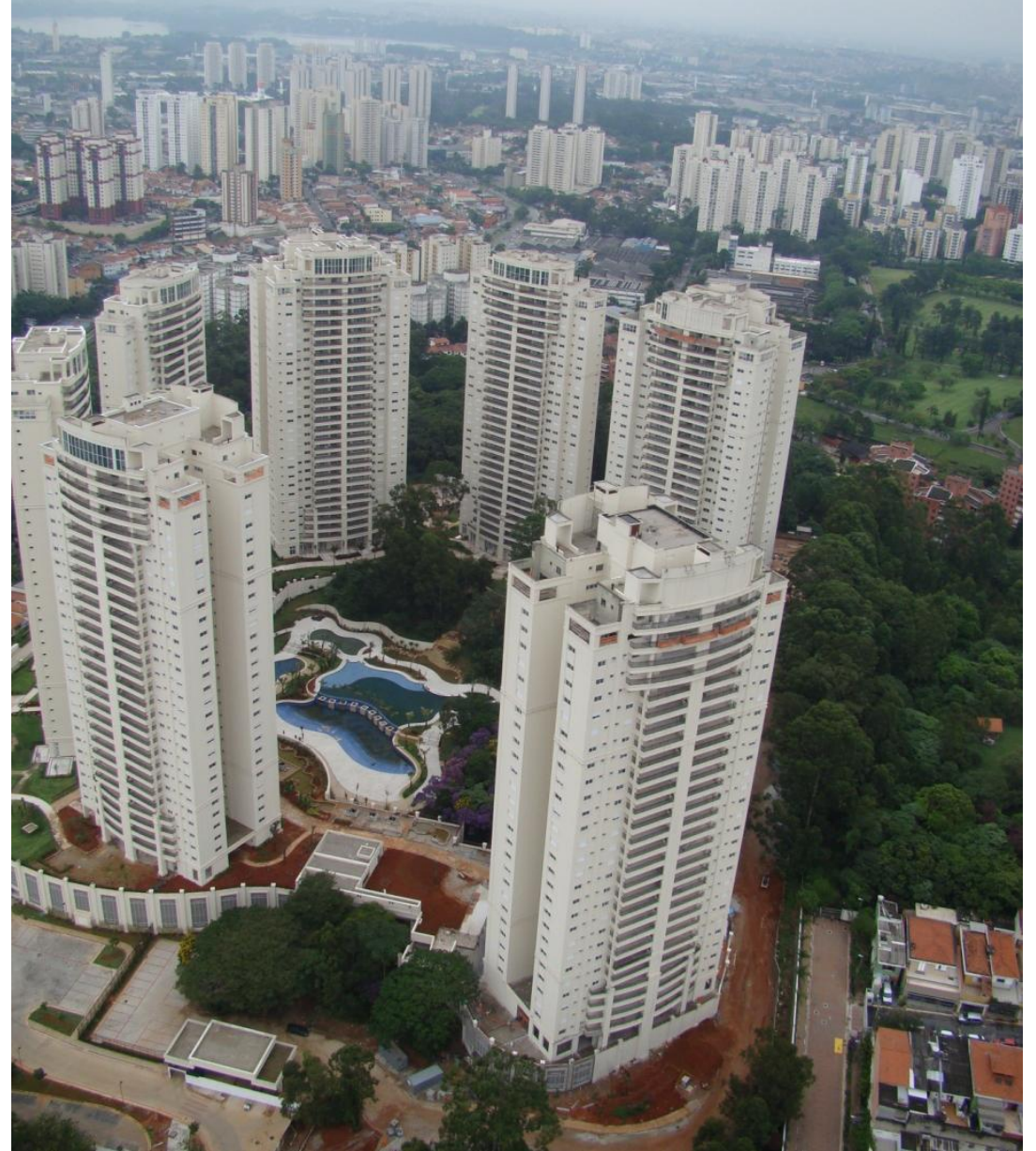

DOMÍNIO MARAJOARA (2007), Jardim Marajoara, São Paulo Sete torres; 594 apartamentos; lote $66.000 \mathrm{~m}^{2}$. Incorporação: Cyrela. Acervo Quapá.

${ }^{5}$ A exemplo do empreendimento Supera Guarulhos (2010), Guarulhos - Incorporadora Trisul. 
Ao longo da década consolidaram-se como a resposta recorrente do mercado imobiliário tendo, ao longo da década de 2000, configurado um modelo, senão "o" modelo, a ser seguido. Com pequenas variações, foram oferecidos não apenas às "elites" e à classe média, tendo sido a principal tipologia no programa de habitação social promovido pelo Governo Federal, Programa Minha Casa Minha Vida ${ }^{6}$ (PMCMV/2009) na faixa de habitação de mercado. Neste trabalho, entendemos este como um fenômeno singular, denominado o fenômeno dos supercondomínios.

Em arquitetura e urbanismo, o fenômeno dos supercondomínios desperta o interesse, pois confirma uma tendência específica de produção de espaço livre de uso comum na reprodução da cidade contemporânea: o espaço livre em condomínio. Entre as torres isoladas de apartamentos, os mais diversos equipamentos, como praças temáticas, bulevares e espelhos d'água recriam, intramuros, estruturas típicas de um possível espaço livre público "ideal”.

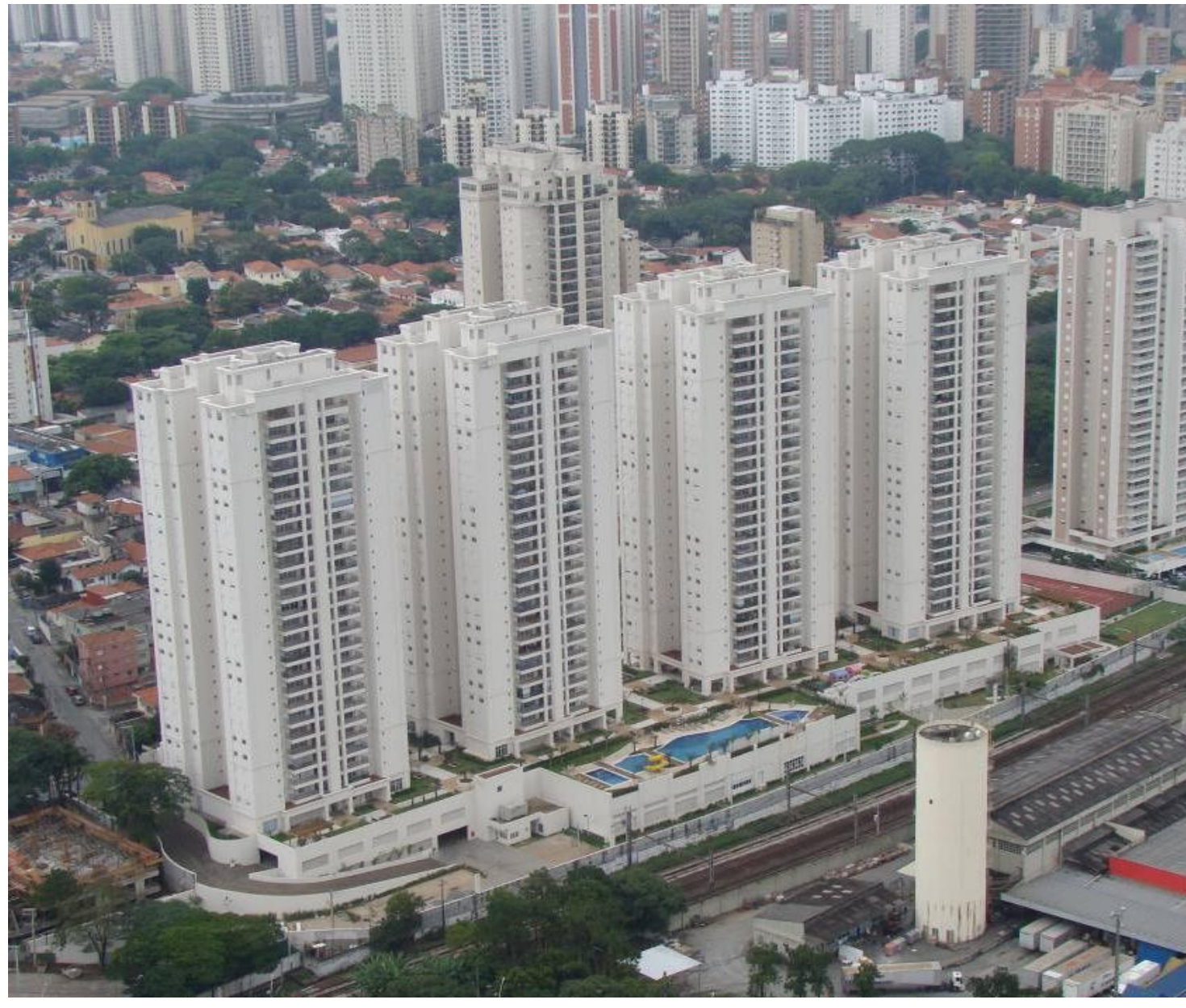

PODIUM (2008) Vila Leopoldina, São Paulo Quatro torres; 384 apartamentos; lote $17.2790 \mathrm{~m}^{2}$ Incorporação: Cyrela.

Acervo Quapá.

${ }^{6}$ Programa habitacional desenvolvido pelo governo federal, lançado em março de 2009 
dividindo o uso e a gestão dos espaços de uso comum, estabeleceram relações alternativas de vizinhança e convivência social, paralelas àquelas típicas dos espaços públicos, com consequências a médio e longo prazo ainda desconhecidas. Com lotes chegando a $74.000 \mathrm{~m}^{2}$ (Green Tamboré), questiona-se também a relação (ou a falta dela) deste modelo de ocupação com a cidade. Grandes lotes frequentemente apresentam grandes perímetros que, com acessos de veículos e pedestres concentrados, resultando em quadras inteiras muradas que, ao reduzir as possibilidades de interação, inibem o uso das calçadas e aumentam a sensação de insegurança.

Pese as críticas, ressaltando a sua condição "antiurbana", a engenhosidade do mercado imobiliário em transformar as suas características em qualidades - o

produto, em sonho - tem se mostrado astuta, e os supercondomínios tornaram-se hoje um objeto de desejo que reafirma uma suposta "nova forma de morar". Reforçando esta tônica, um aparato complexo para a comercialização dos empreendimentos foi estruturado, englobando o uso extremo de perspectivas ilustradas, maquetes, apartamentos modelos decorados, stands de vendas e anúncios em jornais, sempre com ênfase no duo bem-estar/espaços livres de uso comum, com destaque para os elaborados projetos de paisagismo.

Diante deste fato, a pergunta que este trabalho pretende responder é: Por que a produção dos supercondomínios intensificou-se fortemente na Região Metropolitana de São Paulo ao longo da década de 2000? Isto é, quais as causas do fenômeno dos supercondomínios? Questão que dentro da 
área de paisagem e ambiente ${ }^{7}$ ganha uma nova dimensão e se insere em uma reflexão maior: a da produção dos espaços livres na São Paulo Metrópole no início do século XXI.

As análises realizadas focaram nas relações estabelecidas entre a produção imobiliária e o marco regulatório edilício, norteadas pela hipótese inicialmente levantada - e corroborada pelos resultados encontrados - segundo a qual o aumento da produção imobiliária, necessário para o atendimento da demanda latente que emergiu ao longo da década de 2000, baseou-se em estratégias de ganho de escala. Incentivadas pelo marco regulatório edilício, o ganho de escala operacional alcançado pelas grandes empresas do setor, ocorreu por meio do desenvolvimento de projetos progressivamente maiores - em receita, área de terreno e número de torres e de apartamentos - onde as exigências legais de espaços livres e de áreas de uso comum (em condomínio) são potencializadas, viabilizando a oferta de equipamentos e programas de lazer complexos.

A ênfase dada ao marco regulatório edilício nesta proposição fundamenta-se no papel soberano que a legislação desempenha no processo de produção imobiliária formal. Em A Cidade e a Lei, Rolnik vai além e afirma que a lei, ao determinar formas de apropriação de espaço permitidas ou proibidas, "gerando noções de civilidade e cidadania diretamente correspondentes ao modo de vida e à micropolítica familiar dos grupos que estiverem mais envolvidos em sua formulação. [...] funciona como uma espécie de molde da cidade ideal, ou desejável." (2003, p.13). Retomando a questão do lucro imobiliário, ao definir parâmetros, o marco regulatório edilício delimita, intencionalmente ou não, as

\footnotetext{
${ }^{7}$ Paisagem e Ambiente é uma das áreas de concentração do programa de Pós-Graduação da Faculdade de Arquitetura e Urbanismo da Universidade de São Paulo (FAUUSP), que tem entre as linhas de pesquisa Paisagem e Sociedade, englobando projetos de pesquisa com o tema políticas públicas para a paisagem e espaços livres.
} 
oportunidades de lucro oferecidas ao capital imobiliário, apontando a direção a seguir. Por decorrência, este trabalho parte da premissa que o sucesso formal-espacial dos supercondomínios, vide sua recorrência, é a materialização de um ideal de cidade previsto na legislação. Nesta formulação, a justificativa usual do desejo de segregação ou de "exclusividade" - forma pela qual é abordada no discurso de vendas e repetida no meio acadêmico - recebe um papel acessório, entendido, a priori, como uma ideologia criada pelo próprio mercado para ratificar a forma mais lucrativa. A respeito do "capital produtor de moradias", Villaça demonstra clareza quando afirma que "em qualquer caso, ele desenvolve uma ideologia (a venda de um novo estilo de vida, mais moderno e seguro) em torno da 'nova' forma de morar." (2005, p.184.)

Como a observação dos supercondomínios frequentemente suscita um questionamento estético, cabe ressaltar que o trabalho não tem como objetivo realizar uma análise dos projetos dos espaços livres, ou categoriza-los, ainda que por vezes seja mostrada a falta de critérios de dimensionamento ou de qualidade arquitetônica e paisagística dos empreendimentos. Tarefa realizada por vários pesquisadores, entre eles Aragão (2005) e Gavião (2012). A ênfase é dada à sua estrutura formal.

O fenômeno dos supercondomínios pode ser observado, com suas particularidades, nas principais metrópoles brasileiras, mas é no Município de São Paulo (MSP), responsável por, aproximadamente, 40\% do mercado imobiliário formal nacional ${ }^{8}$, que a disponibilidade de dados e o volume de lançamentos oferecem um panorama mais claro. A opção pela análise da RMSP como um todo, e não apenas a capital,

${ }^{8}$ Pesquisa inédita realizada pelo Departamento de Inteligência de Mercado da Imobiliária Lopes no ano de 2010. Segundo este estudo, a RMSP respondeu por 76.000 das 202.000 unidades lançadas, de uso residencial e comercial. Disponível em: < http://blogdemercado.lopes.com.br/2011_02_01_archive.html>. Acesso em 02 de fevereiro de 2012. 
se justifica pela dinâmica imobiliária que se estabeleceu entre a capital, concentrando os lançamentos de padrão médio e alto, e as cidades vizinhas, concentrando os lançamentos de padrão médio e econômico. O período definido abrange a década de 2000 (2001-2010), e visa estabelecer um comparativo da produção pré- Boom (2001-2005) e durante o Boom, (2006-2010).

O método de pesquisa empregado abrange: (i) a caracterização da produção imobiliária de empreendimentos residências verticais $\operatorname{lançados}^{9}$ na RMSP no intervalo acima definido, por meio de avaliação quantitativa, tendo como principal fonte os dados coletados pela Empresa Brasileira de Estudos de Patrimônio (EMBRAESP) ${ }^{10}$; (ii) a espacialização destes dados por meio de software GIS ${ }^{11}$ e; (iii) a análise marco regulatório edilício, em específico as leis de parcelamento e de uso e ocupação do solo, relacionando-o as tendências formais que caracterizam a produção dos supercondomínios.

No primeiro capítulo, Fundamentos, será discutida a produção do mercado imobiliário como tema de estudo acadêmico, apresentando quais as diferentes abordagens que tem sido feitas nas diferentes áreas de pesquisa, particularmente, em arquitetura e urbanismo, onde a ênfase dada à

\footnotetext{
${ }^{9}$ Como critério de análise foi utilizada a data de lançamento do empreendimento, que inaugura o início de sua comercialização. Como o período entre o lançamento, construção e efetiva ocupação das UHs pelos compradores dura cerca de três anos, muitos dos empreendimentos aqui estudados ainda não foram concluídos.

${ }^{10}$ Desde 1985, a EMBRAESP realiza uma pesquisa sistemática dos lançamentos imobiliários em São Paulo. Atualmente há um consenso no meio acadêmico que se dedica ao estudo do mercado imobiliário a respeito de sua confiabilidade, sendo amplamente referida em trabalhos recentes, conduzidos pelo Núcleo de Real Estate da Poli e pela Faculdade de Arquitetura e Urbanismo da USP, entre outras, pois dispõe de um banco de dados para São Paulo com uma profundidade única e praticamente inexistente em outras regiões.

${ }^{11}$ Os dados foram espacializados segundo o código postal do empreendimento. Programa utilizado para geo-referenciamento: Google Fusion Tables + Google Earth. Programa utilizado para a espacialização: Arcgis.
} 
questão social tem encoberto uma análise econômica-financeira deficiente. Discute-se o condomínio enquanto objeto de estudo, e como as leituras que foram feitas na década de 1980 e 1990 sobre os loteamentos fechados, então chamados de "condomínios", acabou por descaracterizar o termo e favorecer a difusão de uma crítica generalista também aos condomínios residências verticais, apesar das profundas diferenças formais.

No segundo capítulo, Mercado imobiliário no início do século XXI, são apresentados os fundamentos que explicam o Boom imobiliário, desde sua origem, no despertar da demanda latente, à nova lógica de reprodução do capital incorporador, relacionando-a ao estabelecimento de tendências formais específicas - aumento do tamanho do lote e do número de apartamentos por empreendimento e a ampla oferta de espaços - que orientaram o desenvolvimento do produto imobiliário e contribuíram para o fenômeno dos supercondomínios.

No terceiro capítulo, A caracterização do fenômeno, é feita uma avaliação quantitativa da produção imobiliária atual. Serão analisados não apenas aspetos formais desta produção, mas também as ideologias que ela envolve, entendidas aqui como parte da proposta de valor que caracteriza estes empreendimentos.

No quarto capítulo, A lógica imobiliária e a lei, é feita a avaliação do marco regulatório edilício sob a óptica do promotor imobiliário - leis federais, estaduais e municipais - destacando a sua influencia no fenômeno dos supercondomínios.

No quinto capítulo, Notas finais, são apresentadas as conclusões deste trabalho, seguido pelos desdobramentos que estas implicam na reflexão sobre o desenho urbano. 

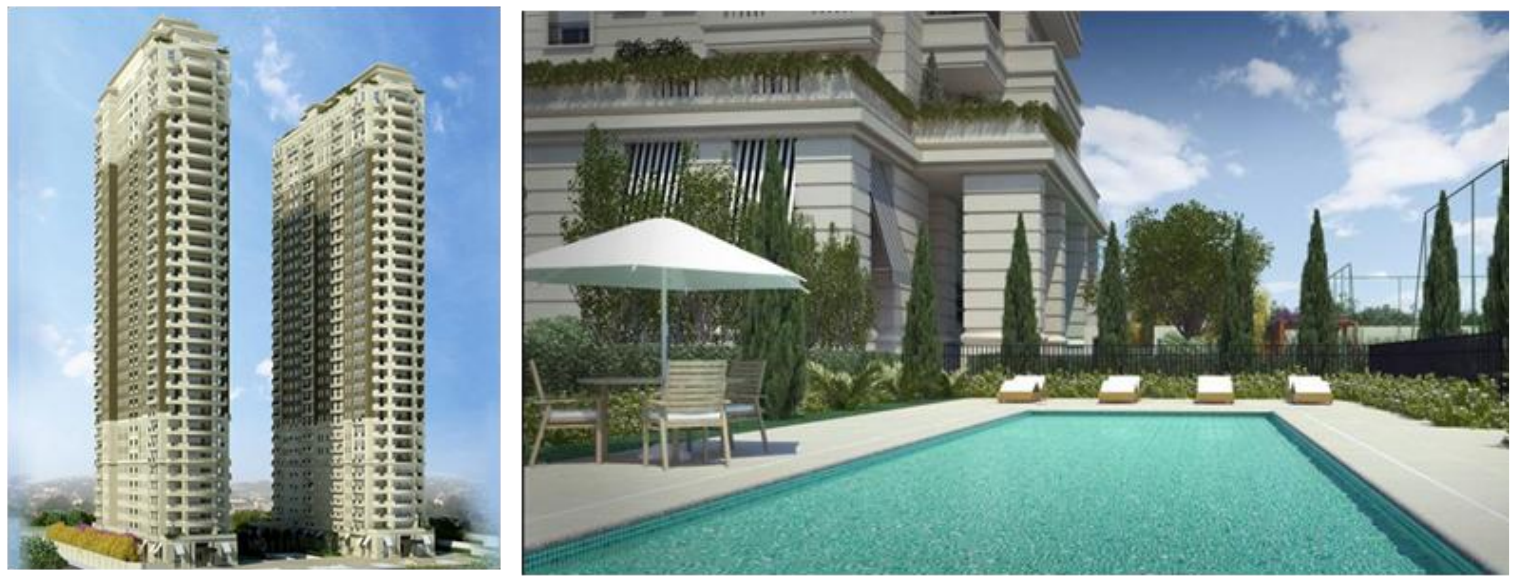

SERIDÓ 106 (2009), Jardim Europa, São Paulo

Ocupando área de $12.683,24 \mathrm{~m}^{2}$, totaliza 132 apartamentos, com metragem a partir de $405 \mathrm{~m}^{2}$ dotados de 4 ou 5 suítes.

Nos espaços livres: academia, piscina,

quadra de tênis e Spa "L'Occitane".

ncorporação: Incorporação JHSF.

Web JHS

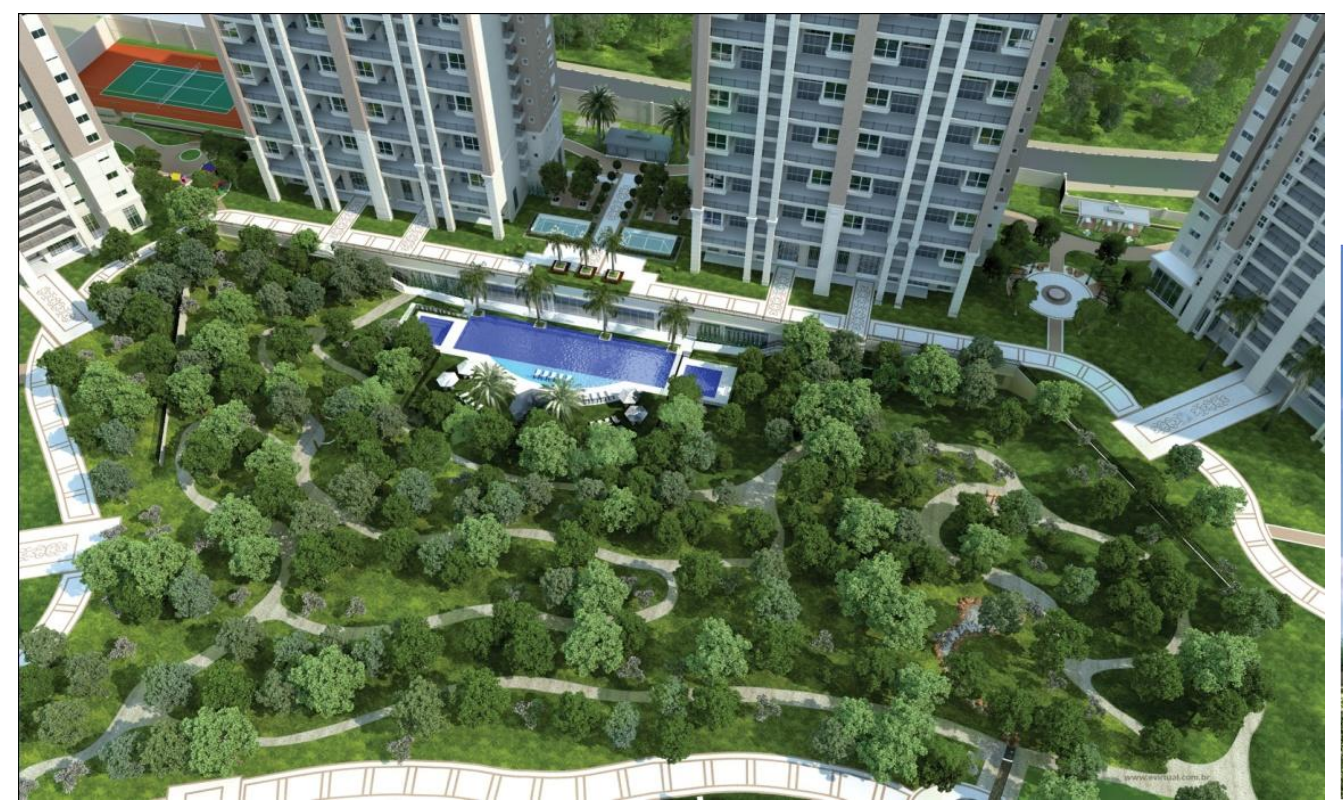

CENTRAL PARK PRIME TATUAPÉ (2007) - Tatuapé, São Paulo

Oito torres: 532 apartamentos; lote 35.246,90 m²

Incorporação: Incorporação Cyrela

Web Cyrela

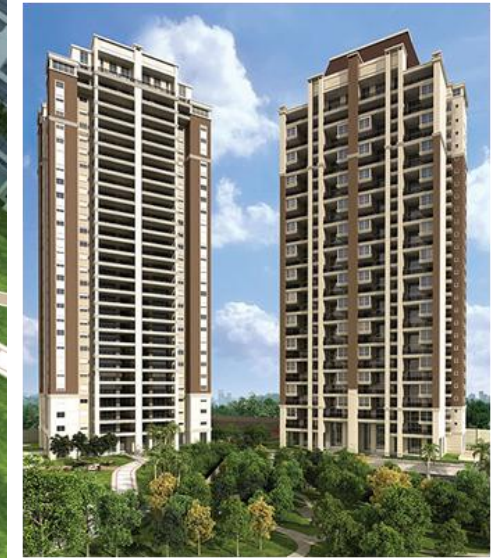




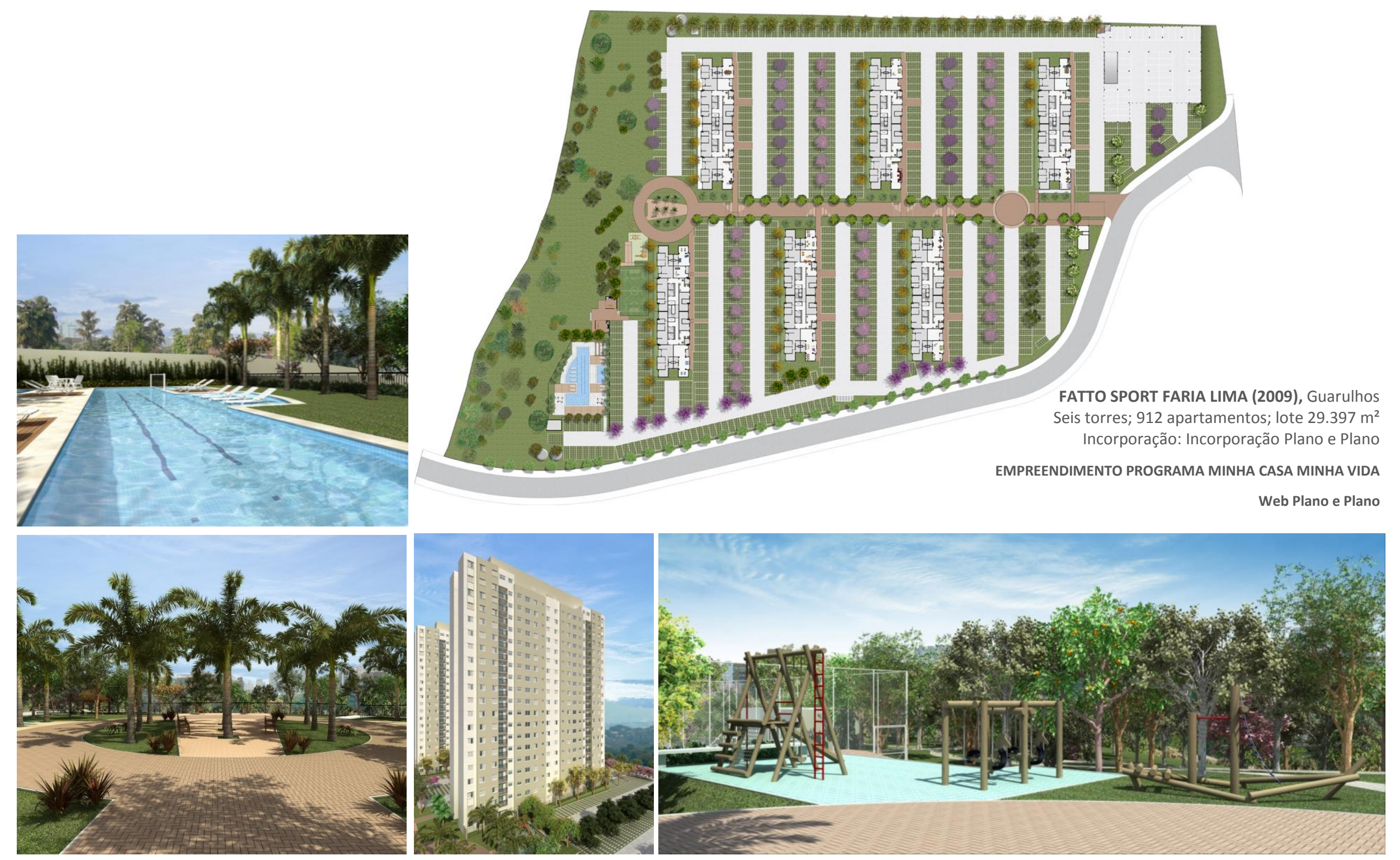




\section{CAPÍTULO 01: FUNDAMENTOS}

\section{1 - ORIGENS DO CONDOMÍNIO}

O significado original do termo condomínio se refere ao modo de propriedade, a posse em condomínio, e caracteriza a relação de domínio compartilhado de um bem - no caso dos imóveis, do terreno e das áreas de uso comum. Regulamentada no contexto da verticalização em São Paulo, no final da década de 1920, tinha por objetivo viabilizar, juridicamente, a comercialização individualizada dos apartamentos e escritórios. A transição para o seu sentido atual, empreendimentos residenciais multifamiliares com ampla oferta espaços de uso comum, ocorreu à medida que as áreas em condomínio deixaram de ser acessórias à área privativa, antes reduzida a pequenas áreas de hall e corredores, e se tornaram protagonistas na qualificação dos edifícios, como já sugeriam projetos de traços modernistas nas décadas de 1940 e 1950.

Com os empreendimentos ganhando em porte físico e o programa dos espaços de uso comum, em complexidade e extensão, a função lazer passou a ser comunicada pelos promotores imobiliários equiparada à função habitar e, na década de 1990, "subcategorias" como Condomínio Clube e Condomínio Parque foram cunhadas e difundidas pelo mercado, para expressar uma "nova forma de morar". 
Neste processo histórico de ganhos de significados econômicos e sociais, o movimento "anticondomínios" ganha força na academia, paradoxalmente, não com a expansão dos condomínios, mas dos loteamentos fechados, que recorrentes na periferia paulistana na década de 1980 , eram comunicados pelas empresas de vendas, de forma equivocada, como 'condomínios' horizontais, mesmo que os espaços livres oferecidos fossem de propriedade pública (ainda que restrita) e não em condomínio, propriamente ditos.

Ao adotar este mesmo conceito genérico, a crítica feita aos condomínios pela academia foi estendida a um grupo heterogêneo de modelos empreendimentos. Com características singulares, o fenômeno dos supercondomínios apresenta uma ruptura e a crítica existente, a exemplo da realizada por Teresa Caldeira (2008), como apresentada adiante, não é suficiente para explicá-lo.

\section{O CONDOMÍNIO E A VERTICALIZAÇÃO}

No Brasil, a propriedade em condomínio de bens imóveis foi inicialmente regulamentada pelo Decreto Federal № 5.481/1928, que criou as bases necessárias à alienação parcial dos edifícios e teve como objetivo a expansão do mercado imobiliário por meio da verticalização. Até então, não havia lei que diferenciasse a propriedade da residência à do edifício, o que significava que a cada edifício correspondia um único proprietário, independente do seu número de apartamentos ou escritórios. Estes eram uma forma alternativa de investimento que permitia às famílias ricas, responsáveis tanto pelo projeto quanto pela construção, obter renda por meio de aluguel. Não por acaso os primeiros edifícios levavam os nomes de famílias tradicionais da elite paulistana, respectivas proprietárias, modismo que acabou sendo continuado mesmo nos edifícios em condomínio, para conferir-lhes status.

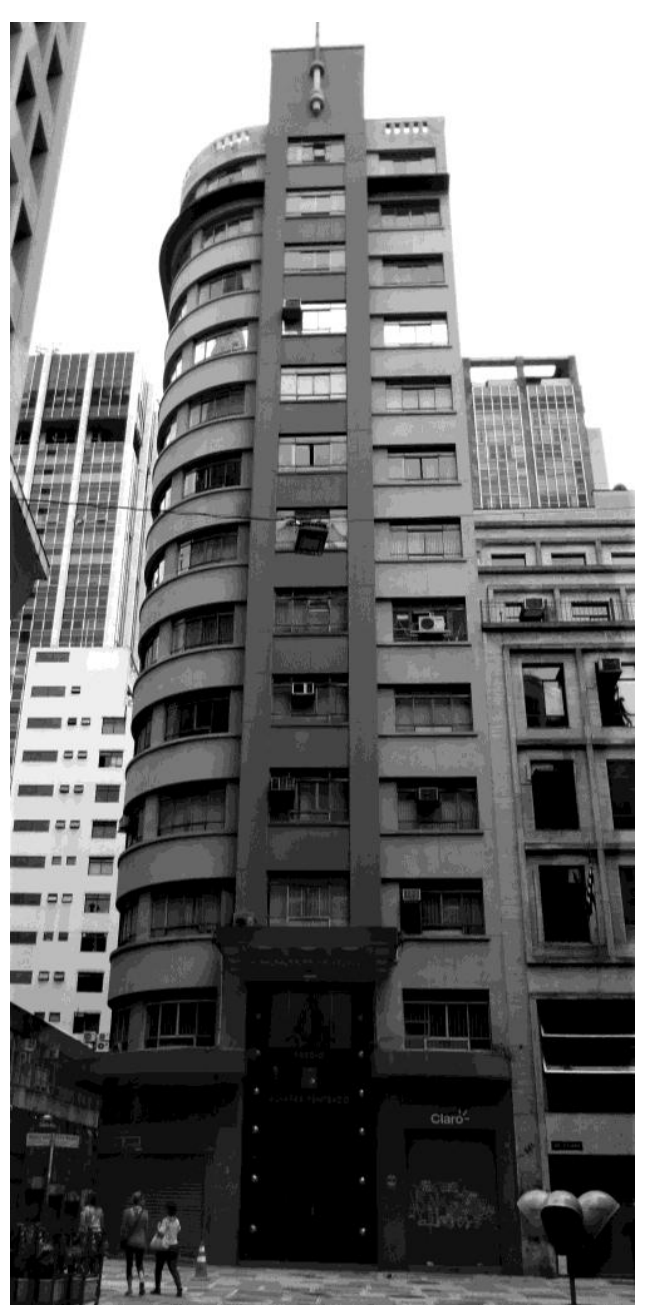

ED. ALVAREZ PENTEADO(1937) Centro, São Paulo Exemplo de edifício com nome referenciando a família proprietária, sem propriedade em condomínio. 22 
A impossibilidade de comercialização dos apartamentos representava uma limitação para classe média crescente, obviamente incapaz de adquirir um edifício todo, mas, sobretudo, um entrave para indústria imobiliária que começava a se estruturar: o apartamento tinha preços mais baixos em relação às casas em um mesmo bairro, mas esta vantagem era anulada pela impossibilidade de adquiri-los individualmente. Um grande mercado em potencial, condicionado a capacidade limitada de imobilização do capital das famílias ricas no mercado locatício. Florenzano (1966) refere-se à Lei Federal № 4.591/ 1964, que deu nova redação ao Decreto 5.481/28, como: “a lei de estímulo à construção civil”"12, deixando claro qual era o seu objetivo principal.

Na prática, o Decreto apenas criou o aparato legal, não sendo suficiente para tornar o produto "edifício em condomínio" acessível. As linhas de financiamento que possibilitariam a aquisição do imóvel à classe-média não estavam presentes em 1928 e o aluguel ainda apresentava vantagens aos locatários. Tardou aproximadamente uma década para que este mercado tomasse forma. Segundo Rolnik (2003, p.192.), com a elevada oferta de crédito no período de 1937 a 1945, ocasionada pelo superávit da balança comercial no período de guerra, dirigiram-se os investimentos para a atividade imobiliária, que, na ausência de um mercado de capitais, apresentava maior rentabilidade e liquidez financeira. Somado a este fato temos a aprovação do Decreto № 1.749, em 1937 , regulamentando “a aquisição de prédios destinados a moradia dos associados dos Institutos e Caixas de Aposentadoria e Pensões" (IAPs) ${ }^{13}$ e em 1946 o Decreto-Lei № 9.218, instituindo a Fundação da Casa Popular (FCP) dedicada "a proporcionar a brasileiros ou estrangeiros com mais de dez anos de residência no país ou com filhos brasileiros a

\footnotetext{
${ }^{12}$ FLORENZANO, 1966 - Livro: Condomínio e Incorporações: Comentários à Lei de Estímulo à Construção Civil.

${ }^{13}$ Oferecendo taxas de juros de $6 \%$ a $8 \%$ e prazos de até 25 anos para amortização.
} 
aquisição ou construção de moradia própria, em zona urbana ou rural”"14. Em 1942, o Decreto-Lei Federal № 4.598 (Lei do Inquilinato) institui o congelamento dos aluguéis, medida que inibiu o mercado locatício, gerando o desaquecimento da produção e redução da oferta de apartamentos para aluguel. Souza (1944, p. 98.) pontua o ano de 1947 como o início da incorporação de edifícios na cidade de São Paulo, devido às desvantagens do mercado de aluguel ${ }^{15}$.

\section{A INFLUÊNCIA DO PROJETO MODERNISTA}

Foi quando os edifícios passaram a ser concebidos para a comercialização individualizada dos apartamentos para as classes média e alta, que o advento das áreas de uso comum em condomínio ganhou uma nova dimensão. Se no início do processo de verticalização a habitação verticalizada era "altamente rejeitada pelo gosto popular e pela classe média, que associava os edifícios multifamiliares a cortiços de pobres" (LEME, 1979), a introdução e valorização das áreas de lazer e contemplação foi protagonista para a mudança desta percepção negativa ao proporcionar uma "nova forma de morar". Solução alinhada com os ideais modernistas que se popularizavam entre os arquitetos brasileiros no período e tão bem atendiam os interesses dos promotores imobiliários.

A estética modernista - redução da ornamentação, o emprego do concreto e plantas de apartamentos compactas (influências dos projetos das unidades mínimas) - era ratificada pelos arquitetos e atendia os interesses dos promotores imobiliários da época. "De modo geral, a

\footnotetext{
${ }^{14}$ Oferecendo taxas de juros semelhantes e prazos de até 30 anos para amortização.

${ }^{15}$ Segundo Bonduki (2004), a Lei do Inquilinato alterou permanentemente a forma de provisão habitacional, sendo o Estado e os próprios trabalhadores responsáveis pela produção de moradias. Reforçando a relação entre promotores imobiliários e atendimento aos interesses da elite que passou a caracterizar o mercado imobiliário paulista.
} 
modernização na arquitetura também ocorreu muito mais por uma necessidade de o capital se reproduzir mais rapidamente, por isso a perda dos ornamentos, e ainda por uma contingência: a mão de obra especializada ou era cara ou estava desaparecendo." (SOMEKH, 1994, p. 161).

O repertório modernista chegou ao Brasil antes que ele pudesse ser exercido enquanto manifestação social. Aquela que é considerada a primeira obra de linhas modernistas no Brasil, a Casa da Rua Santa Cruz (1928), em São Paulo, comprovava que os arquitetos no Brasil estavam a par da discussão que estava sendo feita na Europa, bem como desejavam introduzir este novo vocabulário em suas obras, apesar do contexto adverso: "era uma casa que aparentava ter uma geometria própria para

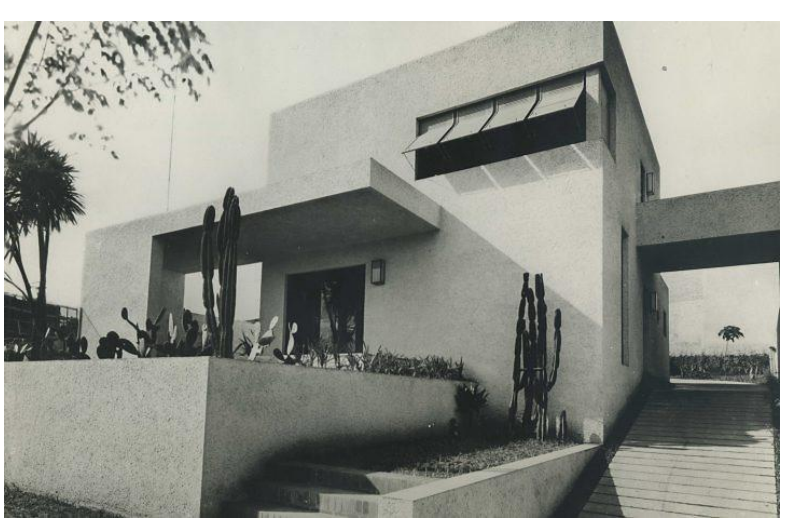

CASA DA RUA STA. CRUZ (1928) São Paulo racionalização da construção, mas era toda de tijolo revestido e não empregava o concreto armado, tampouco componentes pré-fabricados." (SEGAWA, 2002, p. 46). O autor, Gregori Warchavchik (18961972) percebia o papel social da arquitetura modernista, tendo chamado a atenção para a importância da estandardização para o barateamento da obra, já em artigo de 1925 (FERRAZ, 1965, p. 39.).

Mas o modernismo europeu, em referência a prática alemã, estava apoiado em um Estado que tendia ao socialismo ${ }^{16}$, voltado para a provisão de habitação social, e uma indústria da construção que havia amadurecido junto com o movimento modernista ${ }^{17}$, conjuntura bastante diversa da observada no Brasil, onde o desenvolvimento da arquitetura era dependente de uma elite provinciana que, ainda

\footnotetext{
${ }^{16} 70 \%$ dos projetos (habitacionais) de Berlin foram desenvolvidos pela GEHAG, empresa fundada em 1924 controlada majoritariamente por sindicatos socialistas. (BRUNA, 2010, p.91.)

17 "A indústria local, bem que em estado de incessante progresso, ainda não fabrica as peças necessárias, estandardizadas, de bom gosto e de boa qualidade, como sejam: portas, janelas, ferragens, aparelhos sanitários etc." Warchavchik 1928 in SEGAWA, 2002, p. 47.
} 
apegada à estética da residência da elite europeia, conforme atestam as revistas de arquitetura e as de decoração da época ${ }^{18}$, era progressivamente seduzida por uma estética modernista (difundida também pelos arquitetos, que freqüentavam os mesmos círculos de relacionamento), capaz de travesti-la com a modernidade desejada. Assim como Warchavchik, responsável pela organização da exposição "Casa Modernista", evento de inauguração de uma moradia patrocinada pela loteadora Cia. City, responsável pela realização de loteamentos para a classe alta, muitos serão os arquitetos que, antes de dedicarem-se à arquitetura comprometida com o bem social, exercitariam o “modernismo" em casas e edifícios para a elite. A reflexão modernista sobre os espaços de lazer próximos a habitação será chave para a consolidação dos espaços livres em condomínio no edifício de ares de "modernismo".

A visão do espaço livre modernista ganhou destaque na Charte d'Athènes ${ }^{19},(1943)$, publicação idealizada após a o IV Congresso sobre Habitação e Lazer (1933), promovido pelo CIAM. A versão de Le Corbusier tornou-se a mais conhecida ${ }^{20}$, apresentando uma síntese ${ }^{21}$ do ideário modernista, por meio de postulados agrupados em quatro princípios: habitar, trabalhar, recrear-se (nas horas vagas) e circular. $\mathrm{O}$

\footnotetext{
${ }^{18}$ A exemplo da Revista Acrópole, publicada desde 1939.

${ }^{19}$ Publicada no Brasil como "Carta de Atenas".

${ }^{20}$ A "Carta de Atenas é o resultado dos trabalhos desenvolvidos no IV CIAM, em 1933. Há diferentes relatos a respeitos dos pontos discutidos no Congresso. As conclusões dos trabalhos foram organizados e anonimamente publicados por Le Corbusier. "acrescentando tópicos e ênfases que refletiam a sua maneira de encarar as questões." Tendo sido publicadas posteriormente outras versões nos EUA e na Holanda. (SCHERER, 1986: s/n- In Le Corbusier)

${ }^{21}$ “Muitas das soluções propostas (...) Já eram realidade há anos; é o caso do zoneamento funcional, do planejamento regional, dos conjuntos habitacionais provido de eficiente equipamento coletivo, etc. ( As ideias apresentadas já eram conhecidas." (SCHERER, 1986: s/n- In Le Corbusier)
} 
autor enfatiza a importância de atentar ao programa da habitação de forma conjunta com as construções de uso coletivo, sugerindo a dotação de equipamentos de lazer, como "pistas de corrida e piscinas" ${ }^{22}$, de

forma integrada e indica a verticalização para "liberar o solo para amplas superfícies verdes" ${ }^{23}$. Sobre os espaços de lazer Le Corbusier afirmou:

(...) Eles podem ser prolongamentos diretos ou indiretos da moradia; diretos se cercam a própria habitação, indiretos se estão concentrados em algumas grandes superfícies menos

imediatamente próximas. Em ambos os casos, sua destinação será a mesma: acolher as atividades coletivas da juventude, propiciar um espaço favorável às distrações, aos passeios ou aos jogos das horas de lazer. (LE CORBUSIER, 1993, postulado 30)

Orientação também dada por Gropius, em 1956:

Na escolha da forma de habitação, cumpre saber com clareza que se faz necessário comparar não só os custos de produção, mas também as despesas administrativas em tempo e dinheiro. Estas últimas, em particular, são muito maiores na casa unifamiliar (...). O prédio de muitos andares, em contrapartida, é mais ventilado, insolado, e distanciado. Assegura o máximo em áreas verdes, onde principalmente as crianças podem dar largas a seu impulso de brincar e fazer barulho. Também é vantajoso no que tange a repartição dos custos das instalações centrais de ordem administrativa e higiênica. GROPIUS (1997, p. 163-164).

\footnotetext{
${ }^{22}$ LE CORBUSIER, 1993, postulado 37.

${ }^{23}$ LE CORBUSIER, 1993, postulado 29.
} 
O primeiro número da revista de arquitetura Acrópole, de maio de 1938, dedicou 13 páginas ao projeto do Edifício Esther (1936), projetado por Vital Brazil (1909 - 1997) e Adhemar Marinho (1909 1997). O edifício de linhas modernistas, projetado para as classes média e média alta, sobre pilotis e com grandes fachadas envidraçadas, contrastava com os outros projetos apresentados na mesma revista. 0 aproveitamento da cobertura, ainda que tímido, já propunha uma nova relação com os espaços livres, apresentando uma laje ajardinada gramada, com vista para a Praça da República. Os jardins, ainda que restritos aos apartamentos da cobertura anunciavam uma "nova forma de morar" no edifício residencial.

O Conjunto Residencial Anchieta (1943), na região da Avenida Paulista, está entre os primeiros conjuntos residenciais a apresentar espaços livres de uso comum "generosos". Empreendido pelo Instituto de Aposentadoria e Pensões dos Comerciários (IAPC), o projeto empreendido em terreno de $3.000 \mathrm{~m}^{2}$, apresentava 72 apartamentos, com área privativa média da ordem de $100 \mathrm{~m}^{2}$, distribuídos em 10 pavimentos, totalizando $12.900 \mathrm{~m}^{2}$ de área construída (C.A.:4,30 e T.0.: 0,44). Destinado às famílias de renda mais alta, destaca-se da produção característica dos IAPs, voltadas às famílias de perfil médio (BRUNA, 2010, p. 219.). Apresentava um grande jardim de entrada, projeto de Burle Marx (hoje não mais existente devido ao alargamento da Avenida Paulista) além de sala de lareira, salão de jogos e de estar na cobertura ajardinada, playground e quadra. De estética modernista, o projeto foi feito pelo renomado escritório carioca M.M.M. Roberto, considerado um dos principais expoentes do modernismo brasileiro ${ }^{24}$.

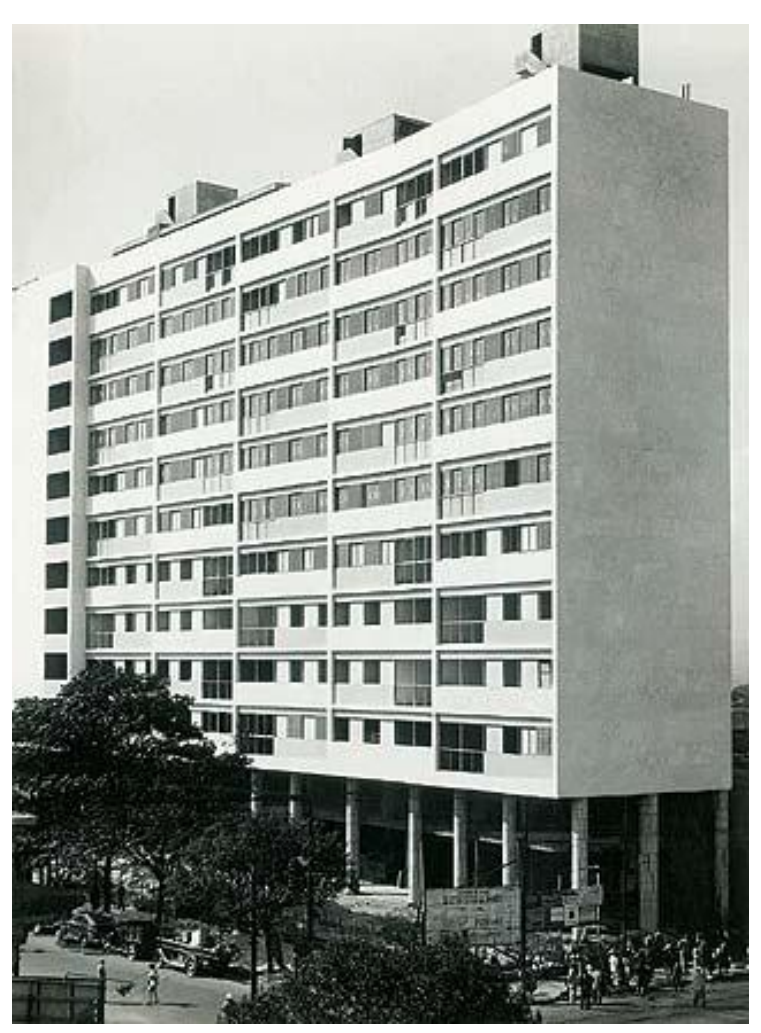

CONJUNTO RESIDENCIAL ANCHIETA (1943) Av Paulista, São Paulo Web Arcoweb

\footnotetext{
${ }^{24}$ O escritório M.M.M. Roberto foi autor, entre outros, dos projetos dos seguintes edifícios: Sede da Associação Brasileira de Imprensa (1935), Aeroporto Santos Dumont (1937) e o Edifício do Instituto de Resseguros do Brasil (1941), todos localizados na cidade do Rio de Janeiro.
} 
Em 1946 foi construído o Edifico Louveira, em Higienópolis. Projeto do arquiteto Vilanova Artigas (1915-1985) de linhas modernistas, com fachada contínua e pilotis, propôs, ainda que timidamente, um conjunto de espaços livres de uso comum. Fez-se valer da localização privilegiada, em frente à Praça Vilaboim, criando uma integração entre esta e um jardim central em meio às duas torres residenciais. $A$ entrada se dá por uma rampa sinuosa que leva aos dois edifícios. Ainda que não configure área de estar, este projeto é representativo sob o ponto de vista dos espaços livre, pois sugeriu uma integração entre espaço público e espaço privado inexistente, e colocou como protagonista, o espaço livre. No ano seguinte, o edifício de classe média Tejereba $(1947)^{25}$, na praia da Enseada, no Guarujá, projeto do arquiteto de Gregori Warchavchik, previa um grande terraço coberto dotado de bar no térreo, integrando os espaços livres ajardinados na frente do edifício com os espaços privados internos.

\section{A OBRA DE JOÃO ARTACHO JURADO}

A obra de João Artacho Jurado (1907-1983), empreendedor imobiliário, "arquiteto" autodidata e proprietário da Monções Construtora e Imobiliária, agrupa elementos de conforto que serão emblemáticos na concepção dos empreendimentos tipo condomínio clube. A despeito da crítica severa que recebiam por parte dos arquitetos de formação, os edifícios de Jurado eram muito bem aceitos pela classe média alta em ascensão, que conforme depoimentos descritos por Franco (2008, p.78) "eram tudo com que se pode sonhar"; "um edifício para o corpo e para o espírito".

\footnotetext{
${ }^{25}$ Revista Acrópole 111 - 1947, julho p. 80.
} 
O Edifício Piauí (1948), localizados em um dos bairros mais desejados de São Paulo na época, Higienópolis, será o primeiro dos característicos edifícios residenciais de Jurado a fazer uso das áreas comuns como mote mercadológico (Jurado anunciava na mesma revista, Acrópole no 151(1950), o Edifico Piauí e a construção de 260 casas unifamiliares em lotes individuais no então distante bairro do Brooklin futuro bairro Monções, nome de sua construtora - em padrão econômico bastante mais baixo, sem fazer uso dos espaços coletivos).

No Edifício Piauí, uma rampa ascendente percorre um estreito jardim chega a um hall em pilotis (elemento que seria recorrente em sua obra) introduzindo um componente cenográfico no percurso da rua à porta de entrada. O Hall Nobre abrange quase todo o térreo e, com móveis de linhas modernas, cria situações de estar. Além dos elevadores, o hall dá acesso ao Jardim de Inverno e um Salão Bar no térreo. Completa a infraestrutura de lazer de uso comum o terraço ajardinado no 11 을

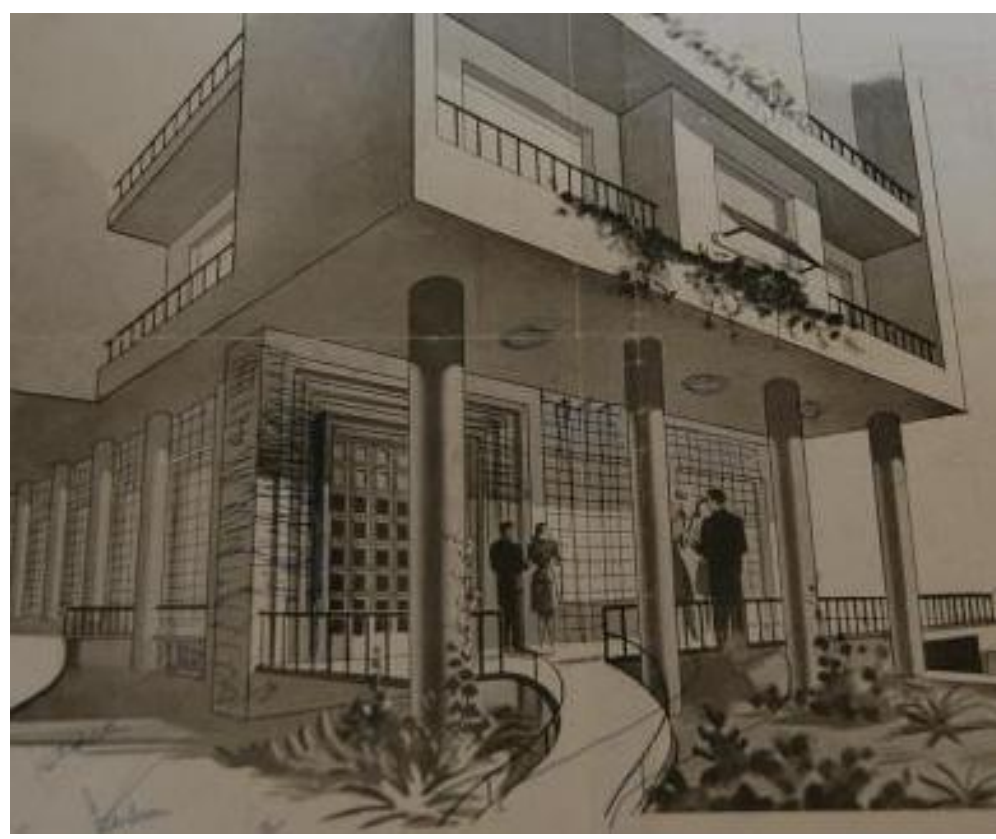

EDIFÍCIO PIAUÍ (1948), Higienópolis Material gráfico utilizado para a comercialização do edifício.

andar. De estética lúdica "americanizada", com uso de pastilhas de vidro coloridas, elementos vazados a aplicação do vocabulário modernista na proposição de amplas áreas privativas de uso comum para interação dos moradores. Como atesta a ênfase dada aos espaços de uso comum no material publicitário, eles são uma extensão dos apartamentos e agregavam valor, no sentido amplo, seja pela infraestrutura de lazer em si, seja pelo status, que a generosidade e sofisticação destes comunicavam aos seus moradores: 
Com a planta do térreo livre das lojas comerciais e de unidades habitacionais, Jurado devolve esse espaço ao condomínio, atribuindo-lhe, de forma pioneira, o uso para lazer e convívio social, em boa parte, porque o bairro de Higienópolis apresentava um viés amplamente residencial, diferente do Centro, que comportava edifícios de apartamentos com lojas comerciais no térreo. FRANCO (2008, p. 149)

Nos próximos anos Jurado lançará uma série de empreendimentos, a exemplo do Edifício Cinderela, Saint Honoré, etc. sendo o Edifício Bretagne (1951) o mais significativo exemplo de sua obra: localizado na Av. Higienópolis, 938, no bairro de

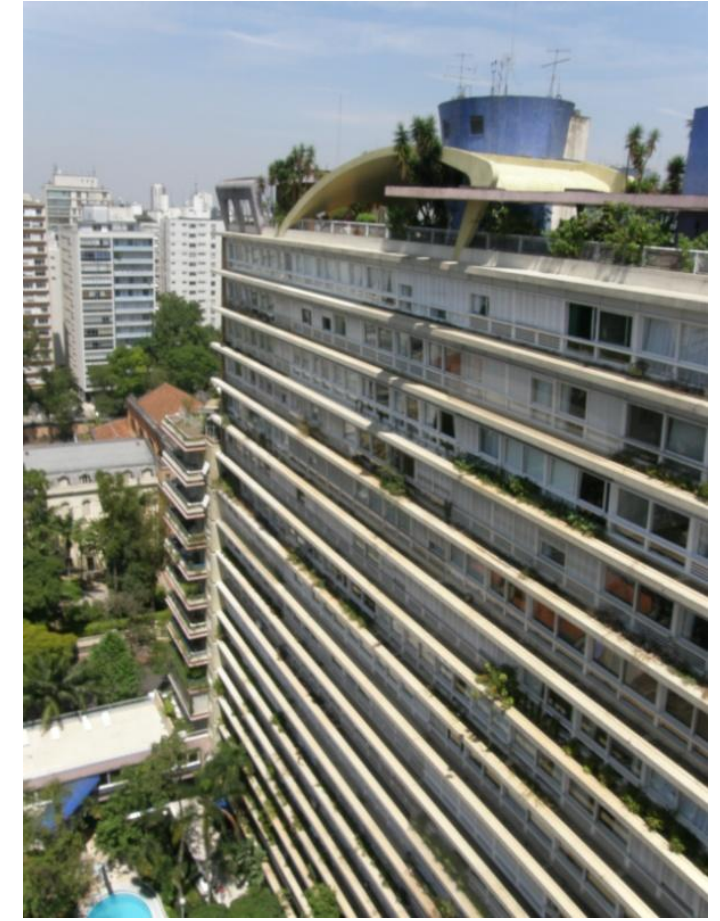

Higienópolis, o edifício de 180 apartamentos - de metragens variadas - distribuídos em 18 andares, 10 por andar, totaliza $25.000 \mathrm{~m}^{2}$ de área total construída em um terreno de $4.000 \mathrm{~m}^{2}($ C.A. $=6,25)$ e, aproximadamente, de $2.500 \mathrm{~m}^{2}$ de espaço livre no térreo (T. O. =0,4).

A torre mais alta do bairro em sua inauguração, o Edifício Bretagne propôs uma revolução dentro do programa de espaços do edifício residencial, oferecendo diversos equipamentos nas áreas comuns. A sua entrada é marcada por um grande volume construído sobre pilotis, que abriga o salão de festas paralelo a rua, forma uma espécie de pórtico de entrada e dá maior privacidade às áreas comuns que prosseguem. O edifício em "L", além de propiciar iluminação natural e um conforto visual, garantindo o

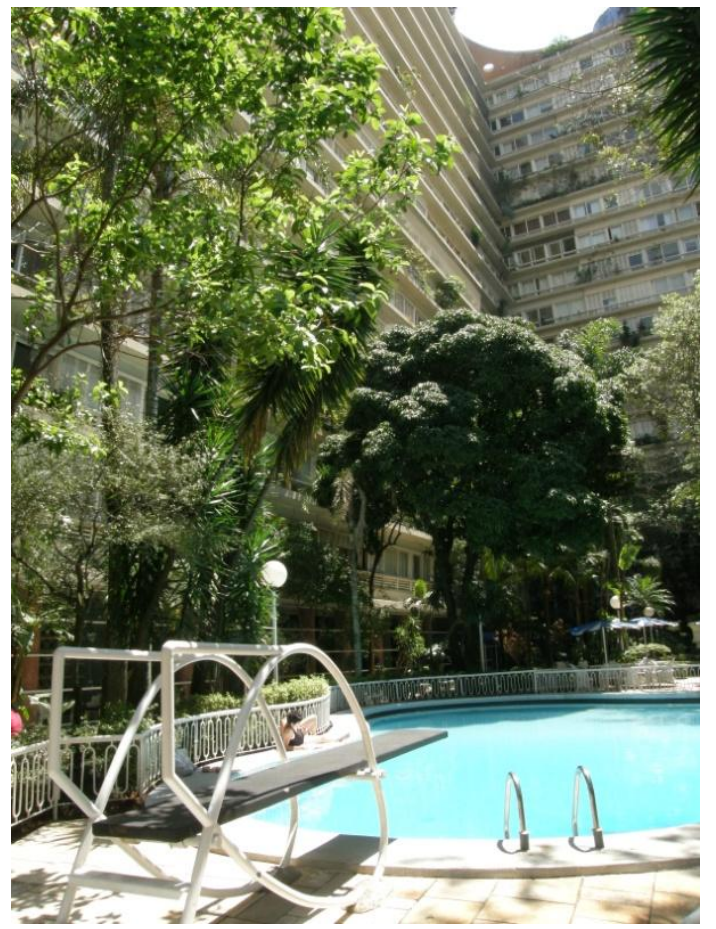

EDIFÍCIO BRETAGNE (1951), Higienópolis Paulo Alas 
afastamento de outras possíveis construções, permitiu a criação de uma grande praça com jardim tropical com espaços de estar, piscina adulto/infantil e playground. Ao redor da praça, um caminho para carros define o percurso onde se acessa os halls dos elevadores (um conjunto de cinco ao total) - Uma via puramente cenográfica, uma vez que a entrada da garagem é feita por um corredor lateral. Um grande hall linear de entrada se estende no térreo, acompanhando a planta em "L", oferecendo um segundo acesso, coberto, aos halls dos elevadores, ao salão de música (com piano de cauda), ao amplo salão bar, salão de recreação infantil (decorado com motivos Disney) e à sala de ginástica.

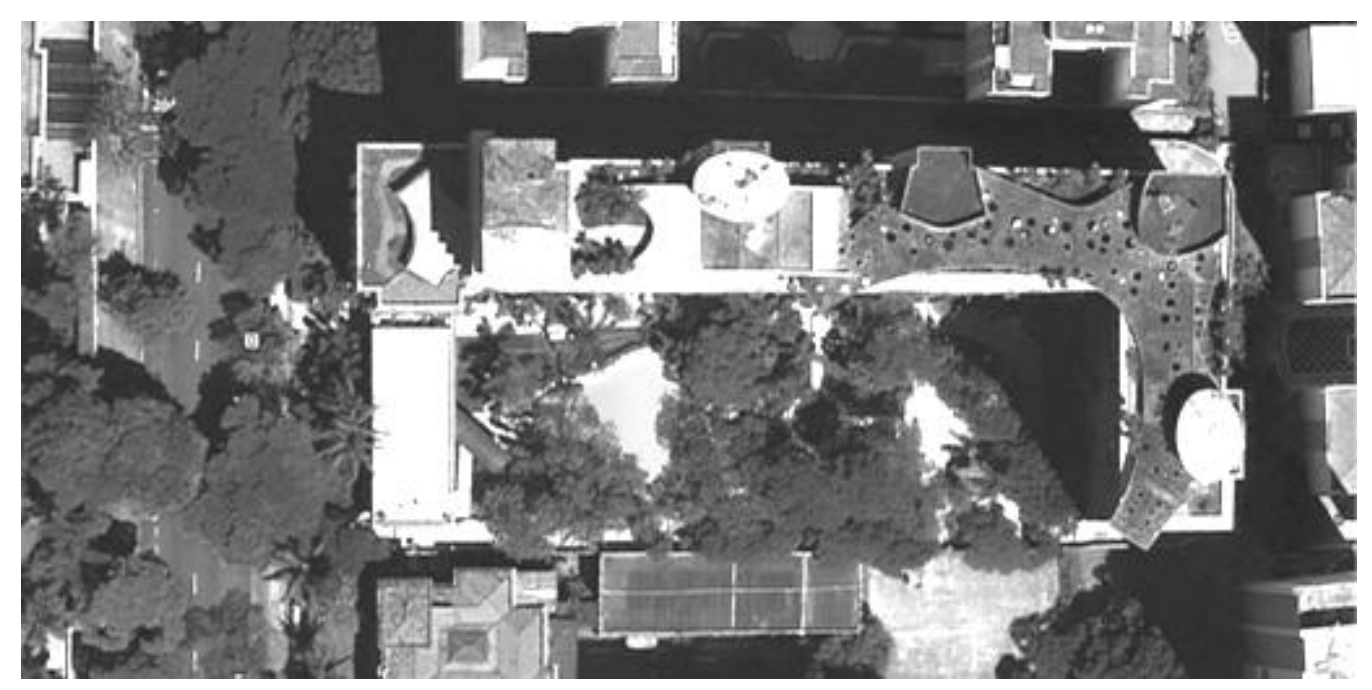

A cobertura ajardinada, no 20 - pavimento, com, aproximadamente, $1.500 \mathrm{~m}^{2}$, oferece uma vista EDIFÍCIO BRETAGNE (1951), Higienópolis Detalhe praça central em " $\mathrm{L}$ ". panorâmica, e inédita na época, da cidade. Ainda que a vegetação na cobertura seja predominantemente rasteira e arbustiva, a vegetação no pátio central do térreo possui árvores de grande porte, a exemplo da mangueira e coqueiros, fato inédito e ainda hoje desafiador, considerando que é este era um jardim sobre laje (abaixo da área de lazer estão dois subsolos com vagas de estacionamento) provavelmente o primeiro significativo em São Paulo. O estacionamento, também inovador, oferecia a opção de apartamentos com duas vagas - inclusive diz-se que os proprietários poderiam no futuro alugar estas aos edifícios vizinhos que muitas vezes sequer tinham uma vaga por apartamento ${ }^{26}$. Acredita-se que

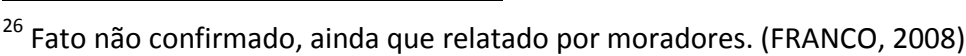


uma série de itens, que não são objeto deste estudo, também foram introduzidos de forma pioneira: o uso do apartamento decorado, a entrega das áreas comuns decoradas e mobiliadas, material de venda primoroso, anúncio de folha dupla em jornal de grande circulação, estudo de mercado para validação do projeto de arquitetura.

Um olhar atento verá que, apesar dos ornamentos e pastilhas coloridas - ao gosto dos edifícios de Miami - principal ponto criticado pelos arquitetos ditos modernos da época, o vocabulário arquitetônico empregado, como bem destaca Franco, é modernista: edifício sobre pilotis, térreo livre com espaços de uso comum, habitação densa e vertical abrindo amplos espaços verdes, integrando ainda que apenas visualmente - o jardim à rua, fachadas continuas, com caixilho piso teto, e cobertura teto jardim, reservada para o uso comum.

Ainda que a inspiração do programa das áreas de uso comum dos primeiros edifícios em condomínio tenha sido o viver da habitação da elite - a casa isolada no lote, com amplos jardins contemplativos, jardins de inverno, salão de festas, salão de música e piscina, que a partir dos anos 40 e 50 "populariza-se entre as elites e torna-se padrão de status possuí-la em casa" (MACEDO, 1999, p. 58.) é o recurso modernista, que no contexto da verticalização trabalha "no lugar de indivíduos isolados, padrões genéricos de comportamento social" (BRUNA, 2010, p. 72.) e introduz a propriedade coletiva.

O projeto do Bretagne é uma leitura de preceitos claramente modernistas, a serviço de uma classe média carente de sofisticação. Ele deu uma nova dimensão à moradia em condomínio, oferecendo espaços que estimulam a interação entre os moradores, seja compartilhando as horas de 'lazer cotidiano', seja pela necessidade da administração compartilhada que estas áreas criam. Ainda que o 
público alvo seja a classe média alta, isto é, o discurso social modernista seja esvaziado (fato comum a praticamente todos os edifícios construídos na região pelos renomados arquitetos modernistas) a posse compartilhada viabilizou a introdução de equipamentos antes inacessíveis a esta classe social, contribuindo para a melhor qualidade de vida de seus moradores.

Não é o caso de fazer uma descrição exaustiva sobre a história do produto imobiliário ou da evolução do programa dos edifícios condomínio tipo "clube". Embora os projetos de edifícios em condomínio produzidos nas décadas seguintes terem maior área e número de unidades, a exemplo do empreendimento residencial Ilhas do Sul (1973) projeto do engenheiro Yojiro Takaoka, ou do Portal do Morumbi (1977), projeto do arquiteto João Henrique Rocha, entende-se que o passo para um novo programa habitar $x$ recrear dentro do espaço privado já foi dado. A antecipação do programa do condomínio clube na obra de

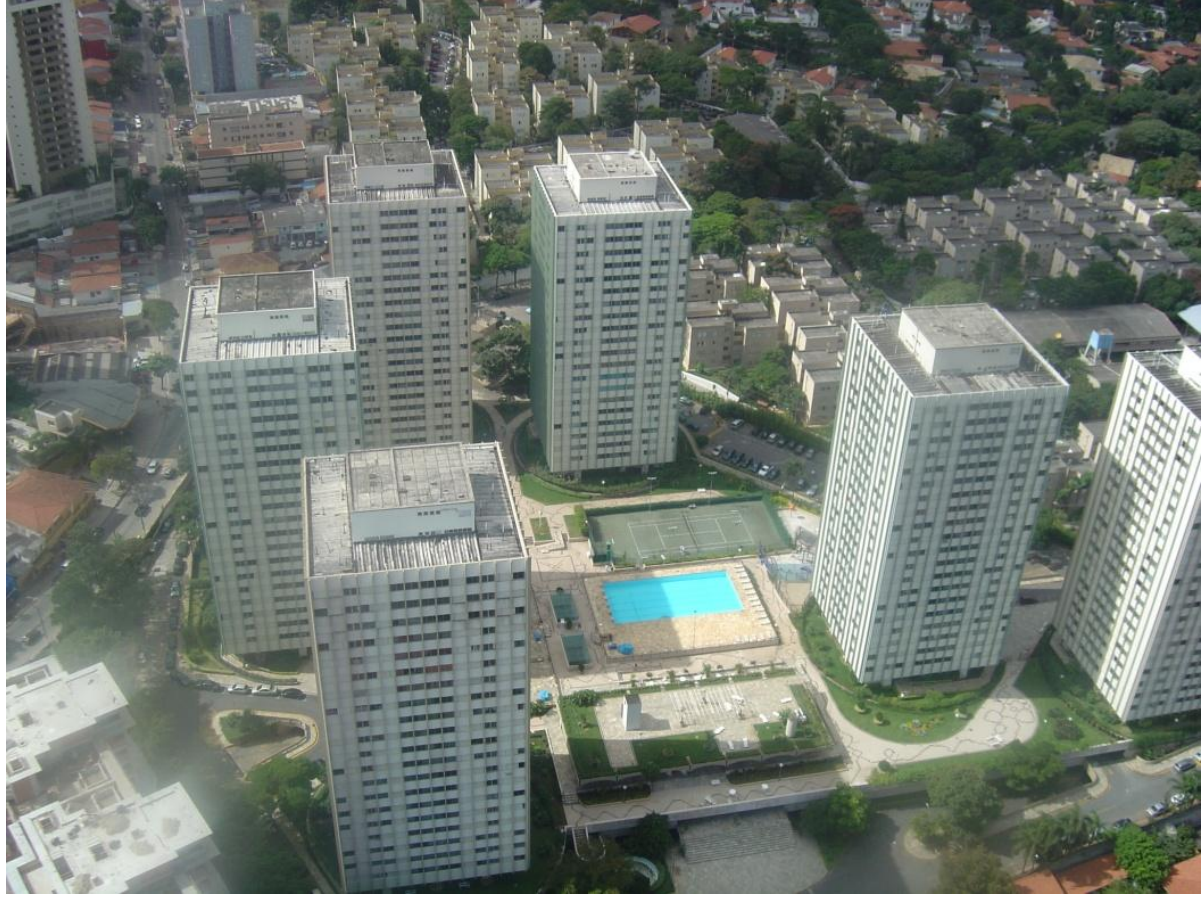

CONDOMÍNIO PORTAL DO MORUMBI (1977), Morumbi, São Paulo Acervo Quapá Artacho Jurado, particularmente no Edifício Bretagne é espantosa, e surpreende o quão pouco

(re)conhecida ela é, tanto no mercado imobiliário como na história da arquitetura brasileira. De forma simbólica, representa o ponto de partida onde, progressivamente, os empreendimentos imobiliários passaram a abrigar em meio urbano amplas áreas de lazer e múltiplas torres, chegando a área de até $80.000 \mathrm{~m}^{2}$. As experiências seguintes não invertem a dialética dos espaços livres de uso privado nos empreendimentos tipo condomínio "clube". Ao contrário, ela será levada ao extremo, no início do século XXI. 


\section{2 - A CRÍTICA AO CONDOMÍNIO}

No Brasil, o estudo do mercado imobiliário formal em urbanismo ainda é pouco desenvolvido e a reflexão crítica sobre a lógica formal-espacial desta produção, escassa. Após décadas de um mercado imobiliário formal incipiente e déficit habitacional crescente, é natural que os estudos em arquitetura e urbanismo no Brasil tenham se concentrado na produção encabeçada pelo Estado, seja na reurbanização e regularização da ocupação informal, seja na provisão de habitação de interesse social (HIS).

A limitação da base teórica existente tornou-se mais evidente no início da década de 2000, com o papel crescente dado aos promotores imobiliários na viabilização das políticas habitacionais e de renovação urbana. Desde a retomada do mercado imobiliário ao longo da década, estes assumiram o posto de principal agente transformador das cidades - diretamente, pela própria produção, e indiretamente, por meio das parcerias e compensações exigidas junto aos órgãos públicos. Da outorga onerosa às operações urbanas, dos Termos de Compensação Ambiental (TCAs) às medidas mitigadoras estabelecidas nos Relatórios de Impacto de Trânsito (RITs), a participação do Estado no desenho da cidade tem se apoiado cada vez mais na produção do mercado imobiliário.

A análise formal-espacial da produção imobiliária em urbanismo focou nas suas consequências, mas limitou o entendimento das suas causas. Enquanto as áreas de economia e engenharia concentraram seus estudos nos fundamentos financeiros do mercado imobiliário e da indústria da construção, arquitetura e urbanismo focaram nas questões sociais, onde a produção imobiliária formal servia mais como contraponto para destacar a crescente disparidade social presente na questão da habitação no 
Brasil. Por décadas a serviço das camadas mais abastadas, não raro a análise da produção formal serviu para crítica dos hábitos de consumo de uma elite dominante, visão que predominou também na discussão dos "condomínios".

\section{O CONDOMÍNIO ENQUANTO UMA GENERALIZAÇÃO}

Confirmando o viés sociológico, os chamados "condomínios" ${ }^{27}$ são exemplos recorrentes nos numerosos textos sobre a segregação social na cidade brasileira, onde nos oferecem um panorama de como estes têm sido percebidos dentro do meio acadêmico. No entanto, cabe destacar que, tanto no meio acadêmico, quanto no mercado imobiliário, o termo "condomínio" desvirtuou-se do seu sentido original, e tem sido utilizado de forma equivocada para identificar empreendimentos de diferentes tipologias. Mesmo com a constatação da inconformidade jurídica nos textos recentes, o termo continuou a ser empregado por força de uso nos textos acadêmicos. O problema deste conceito genérico de "condomínio" - aqui identificado por aspas - está em saber a que tipo de empreendimento o autor esta se referindo, já que engloba edifícios residências verticais, horizontais (de fato condomínios) e também loteamentos fechados (que não são condomínios).

Entre as décadas de 1980 à 2000, a dispersão dos "condomínios" na RMSP foi utilizada para confirmar um novo processo de urbanização, que se opunha ao modelo de urbanização "centroperiferia", característico do período entre as décadas de 1940 e 1980 (CALDEIRA, 2008, p.211.), e apresentava as classes mais abastadas vivendo nas áreas centrais, dotadas de infraestrutura básica,

\footnotetext{
${ }^{27}$ A utilização de aspas alerta para a definição popular mais abrangente do termo, englobando loteamentos residenciais fechados, condomínios residenciais verticais e condomínios residenciais horizontais.
} 
comércio e serviços, e pobres relegados à periferia (espacial), desprovida de infraestrutura básica e à margem da lei. A separação, responsável por evitar o conflito de classes, se daria pelo distanciamento físico garantido pela ocupação dispersa e a dinâmica econômica, por um sistema de transporte público estruturado (CALDEIRA, 2008, p.218.), ainda que precário, garantindo a oferta de mão de obra barata nas áreas centrais.

No novo processo de ocupação, o aparecimento dos "condomínios" de casas para a alta renda em municípios vizinhos como Barueri (Alphaville, Tamboré) e Cotia (Granja Viana) junto a consolidação de cortiços e favelas nas regiões centrais da cidade $^{28}$, a partir do fim da década de 1970, indicava uma mudança no processo de urbanização, denominada "urbanização fragmentada", onde a aparente heterogeneidade na ocupação, com diferentes classes sociais dividindo os mesmos bairros, seria viabilizada à custa de uma arquitetura de muros altos e cercas, estabelecendo-se como uma nova face da segregação.

Para Meyer, Grostein e Biderman a existência de edifícios de alto padrão e favelas ocupando espaços urbanos próximos indicam o fenômeno de "proximidade física e distância social'” (2004, p.220.). Para Arantes, "as novas paisagens de poder e exclusão", onde se incluem os condomínios residenciais, abrem espaço para um "novo código de relacionamento da desigualdade." (2000, p.149. Grifo do autor.) Esta nova dinâmica concede menos a entrada dos pobres da periferia à região central (onde permanecem

\footnotetext{
${ }^{28}$ A região do bairro Morumbi talvez seja o exemplo mais emblemático deste processo, onde os edifícios de alto padrão fazem vista à favela Paraisópolis.
} 
na informalidade), do que cria novos territórios de atuação para o capital imobiliário em locais antes ignorados, estendendo-se como novos bairros da classe média e alta.

A tese de doutorado de Teresa Caldeira (1992), que deu origem ao livro "Cidade de Muros", justamente trabalha sob a idéia de que os "cercamentos" são os responsáveis por permitir a convivência pacífica entre as diferentes classes, uma vez que respondem as questões de segurança e isolamento desejados pelas classes mais altas. O porte e a autonomia de serviços dos "condomínios", atendidos por um sistema viário adequado, permitiriam que estes se localizassem em qualquer contexto - um modelo de habitação imune as adversidades do entorno imediato.

Para Caldeira os "condomínios" - "o tipo mais desejável de moradia para as classes altas" (2008, p.259.), - seriam “enclaves fortificados" ${ }^{29}$, termo semelhante a "fortalezas", empregado por Rolnik $(2003$, p.77.), justificados pelo medo do crime violento. Para Caldeira (2008), fazem parte do mesmo grupo os conjuntos de escritórios, shopping centers, etc.. que tem como características básicas "a propriedade privada para uso coletivo, enfatizam o valor do que é privado e restrito ao mesmo tempo que desvalorizam o que é público e aberto a cidade, são voltados para o interior e não para a rua (...) são controlados por guardas armados e sistemas de segurança" e "aqueles que escolhem habitar esses espaços valorizam viver entre pessoas seletas (...) e longe das interações indesejadas, movimento, heterogeneidade, perigo e imprevisibilidade das ruas."

\footnotetext{
${ }^{29}$ O termo "urban enclaves" foi amplamente utilizado pela sociologia e sociologia urbana desde a década 1980, por autores como Mark Abrahamson, Akel Ismail Kahera e Min Zhou, para referir-se as aglomerações de grupos homogêneos no território, seja por características culturais, econômicas, religiosas, etc.. Não há, necessariamente, um aspecto negativo prévio no conceito.
} 
A independência em relação ao espaço público, ou negação do mesmo, é a perspectiva freqüente na bibliografia. Para Pereira, os grandes "condomínios" se encaixariam na categoria "megaprojetos", "negando o espaço público e urbano ao buscar auto-suficiência privada em relação à cidade. [...] Uma tendência à fragmentação que caracterizaria o momento atual de transformação urbana na América Latina" (PEREIRA, 2006, p.45-46.) que para o autor são um indício das mudanças estruturais, decorrentes de processos locais e globais, devendo ser adequadamente chamada de reestruturação imobiliária.

Macedo já alertava em sua tese de doutorado sobre a verticalização na cidade de São Paulo [1988] para a falta de discussão sobre o que estava sendo produzido, para quem o mercado imobiliário estaria "criando, elaborando e difundindo padrões de ocupação do solo verticalizados que são aceitos, consumidos e muito pouco discutidos" $(1988$, p.15.) e, portanto, interferindo no sistema de espaços públicos da cidade:

O padrão de usos de espaços da cidade abandona o espaço da rua como entidade múltipla em favor da função única - circulação de veículos, como cria outras relações de espaço livre disponível para atender à nova população abrigada nas torres, seus veículos e filhos relações estas baseadas em padrões de adensamento quantificado e nunca qualificado. (MACEDO, 1988, p.14.)

Na afirmação de Macedo, podemos ainda inferir que a falta de qualificação da produção derivaria também da falta de discussão e, conseqüentemente, de critérios para avaliar a nova produção - situação que 25 anos depois permanece semelhante.

O surgimento de um novo modo de vida também é levantado por De Marchi. A respeito dos empreendimentos imobiliários lançados nas antigas áreas industriais da Zona Leste na década de 2000, a 
autora afirma que, "o distanciamento da cidade proposto por estes novos padrões de morar tem demonstrado uma 'cidade dentro da cidade' rejeitada por ela." (2007, p.257). Para a autora, a questão da violência urbana seria a explicação dada por incorporadoras e construtoras para o sucesso dos grandes condomínios, onde estariam protegidos por muros e câmeras: "Dentro destas áreas privativas, protegidos por altos muros e sistemas de vigilância, novos espaços de gentrification estão sendo construídos não as bordas da cidade, mas em seu tecido interior, delimitando novas barreiras urbanas." (Ibidem, p.251.). Ela destaca que a possibilidade de se ganhar tempo "trocando o deslocamento horizontal pelas vias da cidade, pelo vertical dos elevadores de acesso no acesso às facilidades do mundo urbano tem moldado (...) um novo modo de viver dentro e protegido da cidade". Nesta justificativa, no entanto, a autora não cita as economias de escala que os supercondomínios oferecem aos moradores - como divisão de custos de portaria e manutenção dos espaços livres - argumento explorado pelas incorporadoras.

Em artigo de 1993, entitulado “O papel da rua na urbanização paulista”, Meyer mostra um ponto de vista diferente. Para a autora "a evidente erosão do espaço público transferiu as atividades urbanas para novos 'territórios', produzidos segundo novos valores e utilizando obrigatoriamente novos instrumentos. Os condomínios fechados, os shoppings centers, os edifícios são exemplos emblemáticos da nova organização física das atividades urbanas, em que a rua é desinvestida de suas funções e papéis." (1993, p.26.). Desta forma, o “condomínio" seria também conseqüência de um esfacelamento do espaço público, e estaria armado um círculo vicioso, onde há uma progressiva perda dos usos típicos dos espaços públicos, para estes novos espaços privados de uso comum. 
A obra de Caldeira talvez seja aquela que se debruçou sobre o tema "condomínios" com maior profundidade e permanece como a principal referência dentro do meio acadêmico. Há, no entanto, generalizações que, duas décadas depois, não são suficientes para explicar a proliferação dos supercondomínios verticais na década de 2000.

Em sua tese, a autora não faz distinção entre os loteamentos ilegais de alta renda na periferia, para os condomínios verticais e horizontais nas áreas centrais, chamando-os todos de "condomínios", forma pela qual são apresentados pelo mercado. Apesar de citar exemplos de empreendimentos no Morumbi, o seu principal objeto de estudo é o primeiro grupo (que, juridicamente, não são condomínios). Sendo a popularização dos condomínios residenciais verticais com ampla oferta de lazer - os chamados condomínios clubes - mais recentes que o dos loteamentos fechados de alto padrão, é normal que a crítica ao "condomínio" tenha sido construída sobre esses. Mas a diferença de público, de representatividade ${ }^{30}$, localização, de área de terreno por habitante (ou fração ideal), de forma de propriedade da terra e legislação incidente impedem uma análise conjunta da lógica econômica presente nos diferentes modelos de ocupação.

\footnotetext{
${ }^{30}$ Não foi possível acessar dados atuais sobre a produção de casas em condomínios na região de Alphaville, contudo, segundo a revista veja São Paulo de 12 de março de 1997 (p.10), posterior à tese de Caldeira, Alphaville tinha 7 mil residências e 12 prédios de apartamentos, o que, considerando 24 anos passados da inauguração do loteamento, é pouco e não representa um movimento dominante da elite paulista. Segundo o CENSO 2000, o distrito de Jardim Paulista, um dos principais bairros de elite tinha mais de 32 mil domicílios.
} 
O QUADRO 01 apresenta uma comparação entre os diversos tipos de empreendimento que o termo "condomínios", usado de forma simplista, buscou abranger: loteamento fechado ${ }^{31}$, condomínio horizontal e condomínio vertical. Observa-se que, do ponto de vista conceitual, as três formas de ocupação são bastante distintas. O loteamento fechado é característico da periferia das cidades, onde o custo reduzido do solo viabiliza a aquisição de lotes maiores. O condomínio vertical, via de regra, apresenta-se em áreas urbanas - fato reforçado uma vez que, segundo a lógica imobiliária vigente, a verticalização só se justifica quando o custo do solo é alto: a verticalização leva ao adensamento (construtivo e populacional) e o valor do terreno é diluído. Os loteamentos fechados estão pautados no uso do carro, inclusive internamente, e a distância dos centros urbanos é um fator positivo. Os condomínios verticais ambicionam oferecer o "oásis urbano", com rápido acesso a serviços e transporte público, dentro dos centros urbanos.

\footnotetext{
${ }^{31}$ Como referência de loteamento fechado, utilizou-se o Tamboré I, em Alphaville, Barueri - por ser exemplo recorrente nos textos aqui discutido.
} 


\begin{tabular}{|c|c|c|c|}
\hline & LOTEAMENTO FECHADO (TAMBORÉ I) & CONDOMÍNO HORIZONTAL & $\begin{array}{l}\text { CONDOMÍNIO VERTICAL (base } \\
\text { amostragem RMSP - 2001-2010) }\end{array}$ \\
\hline OCUPAÇÃO & horizontal & horizontal & vertical \\
\hline ÁREA & 1,86 milhões de $\mathrm{m}^{2}$ & de 2.500 a $74.000 \mathrm{~m}^{2}$ & de 2.500 a $74.000 \mathrm{~m}^{2}$ \\
\hline DENSIDADE POPULACIONAL & baixa ( 702 lotes - 370 residências) & média & alta \\
\hline DENSIDADE CONSTRUIDA & baixa & alta & alta \\
\hline TERRENO POR HABITAÇÃO & de 1.000 a $5.000 \mathrm{~m}^{2}$ & $62 m^{2}$ (fração ideal MSP) & de 30 a $60 \mathrm{~m}^{2}$ (fração ideal MSP) \\
\hline REALIZAÇÃO & loteadora & incorporadora & incorporadora \\
\hline COMERCIALIZAÇÃO & lotes & casas/sobrados & apartamentos \\
\hline REGIME DE CONSTRUÇÃO & construção assistida & produção industrializada & produção industrializada \\
\hline PÚBLICO & principalmente classe alta & todas as classes & todas as classes \\
\hline $\begin{array}{l}\text { LOCALIZAÇÃO (NO MOMENTO DO } \\
\text { LANÇAMENTO) }\end{array}$ & distante do entorno urbano & distante e dentro no meio urbano & dentro no meio urbano \\
\hline ESPAÇOS E EQUIPAMENTOS DE LAZER & $\begin{array}{l}\text { predominantes privados } \\
\text { (piscina, churrasqueira, etc..) }\end{array}$ & $\begin{array}{l}\text { de uso comum } \\
\text { (piscina, churrasqueira, etc..) }\end{array}$ & $\begin{array}{l}\text { de uso comum } \\
\text { (piscina, churrasqueira, etc..) }\end{array}$ \\
\hline $\begin{array}{l}\text { SITUAÇÃO JURÍDICA DOS ESPAÇOS LIVRES } \\
\text { DE USO COMUM }\end{array}$ & propriedade pública de acesso restrito & propriedade privada em condomínio & $\begin{array}{l}\text { propriedade privada em } \\
\text { condomínio }\end{array}$ \\
\hline
\end{tabular}

ELABORAÇÃO: Autor

A produção do condomínio horizontal concentra-se em pequenos lotes urbanos, onde a verticalização não é possível (exemplo destes são, principalmente, as novas vilas aprovadas no MSP), ou em áreas periféricas, onde o custo do solo é reduzido, neste caso, atendendo principalmente o segmento de padrão econômico.

Por fim, os espaços livres criados nos condomínios verticais e nos horizontais, são de propriedade em condomínio (privada), e os equipamentos visam atender as necessidades coletivas. Nos loteamentos 
fechados, há uma apropriação do espaço público, cercado e controlado. Com lotes maiores, piscinas, churrasqueiras, e outras amenidades são de uso individual de cada família. A interação social é "opcional", estando os espaços públicos voltados, sobretudo, para o atendimento das necessidades de circulação.

A generalização do termo teve algumas consequências graves para a discussão acadêmica. Por exemplo, a similaridade de Alphaville com o modelo de atuação do mercado imobiliário americano tem favorecido a discussão acadêmica dos "condomínios", com base na crítica estrangeira feita às edge cities, gated communities e suburban district americanos, inclusive quando se referem aos condomínios residências verticais.

A conclusão de que "à medida que as elites se retiram para seus enclaves e abandonam os espaços públicos para os sem-teto e para os pobres, o número de espaços para encontros públicos para pessoas de diferentes grupos sociais diminui consideravelmente" (CALDEIRA, 2008, p.301.) parece não ser válida nos condomínios verticais e dos bairros centrais ${ }^{32}$, já que, no caso da RMSP, não há dados que comprovem essa retirada em massa da elite dos bairros tradicionais, ou mesmo uma mudança significativa de comportamento restrita a este grupo. A aparente "crise" do sistema de espaços livres da

\footnotetext{
${ }^{32}$ Caso a segurança dos loteamentos estudados pela autora fosse uma necessidade de tal ordem para as classes média e alta, poderia ser observado uma fuga dos bairros tradicionais de elite para estas localidades, em proporções que levariam à redução do preço das propriedades e dos apartamentos nos bairros centrais tradicionais - o que, de fato, não ocorreu. Pelo contrário, ainda hoje um apartamento ou casa em Alphaville, se comparados com opções semelhantes nos bairros tradicionais de São Paulo (Jardins, Vila Madalena, Pinheiros, Higienópolis), serão consideravelmente mais baratos, apesar de dotados de sistemas de segurança mais sofisticados. É preciso lembrar que a necessidade básica de segurança, tem sido questionada na atualidade pelas agências de publicidade para orientar a compra de novos produtos pelo consumidor nos mais diversos segmentos: carros mais seguros, trabalhos mais seguros, relacionamentos mais seguros e casa mais seguras.
} 
cidade levantada pela autora e também por Regina Meyer (2001), e que ainda pode ser observada, permitiria levantar outros fatores determinantes que não a criação dos "enclaves fortificados", a exemplo do surgimento de novas formas de lazer, como vídeo games, computadores e internet, novos espaços de lazer, como academias, assim como alteração na rotina de trabalho, o trânsito e outras atividades que direta ou indiretamente concorrem pelas horas livres que poderiam ser despendidas nos espaços públicos. Possibilidades estas que também justificariam o uso reduzido das infraestruturas de lazer encontradas nos próprios condomínios estudados por Caldeira. Ainda assim, exemplos como o do Parque do Ibirapuera, do Parque Villa Lobos e da Avenida Paulista em São Paulo serviriam de contra exemplo, sendo palco da mais intensa mistura de classes e conservando em suas redondezas alguns dos maiores preços de imóveis da capital.

Pesquisas de uso e ocupação realizadas na década de 2000 têm colocado em dúvida o "abandono" da cidade pelos moradores dos condomínios, bem como a expressão "cidade dentro da cidade", como colocam De Marchi (2007, p.257.) e Fix (2007). Em sua tese de doutorado Moura analisa os "condomínios" horizontais encontrados na periferia de Goiânia e conclui que "as mesmas pessoas que decidem habitar os condomínios transitam nas cidades para trabalhar, fazer compras se divertir, estudar e fazer tratamentos médicos." (2003, p.19.). Isto é, o "condomínio" não eliminaria a dependência com o espaço da cidade, mesmo no que se refere ao lazer. Em pesquisa junto a moradores de loteamentos fechados em Belo Horizonte, Andrade (2006, p.311.) conclui que: 
O que se extrai das falas destes moradores é que já vinham experimentando nos bairros das grandes cidades, onde antes residiam, modos de vida segregados. Assim, identificam mudanças em suas vidas, mas não exatamente uma ruptura. Este aspecto é importante para se pensar os condomínios não como exceções, mas como radicalizações de formas de morar e de conviver também presentes nos espaços centrais das cidades.

Parte da interpretação dada por Caldeira, compartilhada por outros autores ${ }^{33}$, se explica pela postura que adota em sua pesquisa, que, segundo ela, concentra-se na "análise sobretudo no que essas residências expressam publicamente no espaço da cidade"(CALDEIRA, 2008, p.265.). Desta maneira, a autora opta por interpretar o aparecimento dos "condomínios" dentro da descrição formal que faz da cidade e não investiga a opção dos promotores imobiliários por este modelo de negócios.

O fator subestimado mais claro é o papel do marketing imobiliário na difusão de uma ideologia. A análise que autora apresenta, com bases nas propagandas veiculadas pelo mercado imobiliário, dá a entender que a estrutura formal dos condomínios, propagandeados como "fortalezas" auto-suficientes, seria resultado de uma arquitetura concebida para responder aos desejos de segurança de seus moradores. Isto é, os argumentos de vendas "segurança" e "segregação" - este último apresentado como "lazer exclusivo", "parque privativo" e "ambientes sofisticados" - teriam levado os promotores imobiliários a elaborar um produto que tivesse como característica principal espaços de uso comum privativos e murados: conclusão que poderia explicar, talvez, o fechamento dos loteamentos encontrados de Alphaville e Granja Vianna, mas que nesta reflexão discute-se não ser uma das causas preponderante

\footnotetext{
${ }^{33}$ Como dito anteriormente, o trabalho de Caldeira é a principal referência no tocante aos condomínios. Há mais 650 citações em livros e artigos encontrados por busca virtual (Google acadêmico) (data: 01/12/2011).
} 
para explicar o fenômeno dos supercondomínios, ainda que, formalmente, configurem "fortalezas" e possam ser interpretados como símbolos da segregação. É interessante destacar que a segregação, por mais que seja condenada de forma unânime nos textos acadêmicos, é uma característica que qualifica, confere status ao empreendimento imobiliário e, por adicionar valor, vem sendo utilizada de forma recorrente pelas agências publicitárias, mesmo quando não é um partido adotado na concepção original do produto. 


\section{CAPÍTULOS 02 - MERCADO IMOBILIÁRIO NO INÍCIO DO SÉCULO XXI.}

Se a primeira década de 2000 foi um momento histórico ímpar para o mercado imobiliário brasileiro, também o foi, por efeito, para as cidades brasileiras. Na mídia, o momento ficou conhecido como o Boom imobiliário. Na RMSP, centro do Boom, o número de UHs lançadas aumentou vertiginosamente a partir da segunda metade da década (QUADRO 01). Mesmo já mostrando sinais de desaceleração, especialmente após 2009, quando a retração dos números refletiu a insegurança provocada pelo Bust $^{34}$ do mercado imobiliário americano, o mercado brasileiro tem permanecido aquecido $^{35}$.

Para aquele que se ateve a tipologia dos empreendimentos lançados, surpreendeu a repetição dos conjuntos residências verticais apresentando uma suposta "nova forma de morar", expressada pela ampla oferta de espaços de lazer, livres e cobertos, em condomínio. Na prática os supercondomínios, enquanto modelo de empreendimento, já eram conhecidos no mercado habitacional - como mostrado anteriormente - ainda que tenham tido programa de espaços atualizado. A novidade ficou pela sua recorrência e pelo ganho de porte físico. O que poderia ser apenas uma nova roupagem, um argumento de vendas sem fundamento real, ou apenas reflexo da maior exposição que os empreendimentos

\footnotetext{
${ }^{34}$ Em referência ao termo empregado por Sowell (2010) em seu livro The housing boom and bust.

${ }^{35}$ Em referência ao ano de 2012, quando da redação desta dissertação.
} 
imobiliários ganharam na mídia - a exemplo das infindáveis anúncios de jornal ${ }^{36}$, bandeiras, homenssetas e panfletos distribuídos nas ruas - mostrou-se ser o sinal de uma transformação profunda do produto imobiliário, de um novo fenômeno, onde o processo acelerado de produção e reprodução do solo urbano apresentou novas formas de ocupação que vêm descrevendo uma nova paisagem urbana metropolitana.

GRÁFICO 1: EVOLUÇÃO DO NÚMERO DE UNIDADES HABITACIONAIS LANÇADAS NA RMSP ENTRE 2001-2010

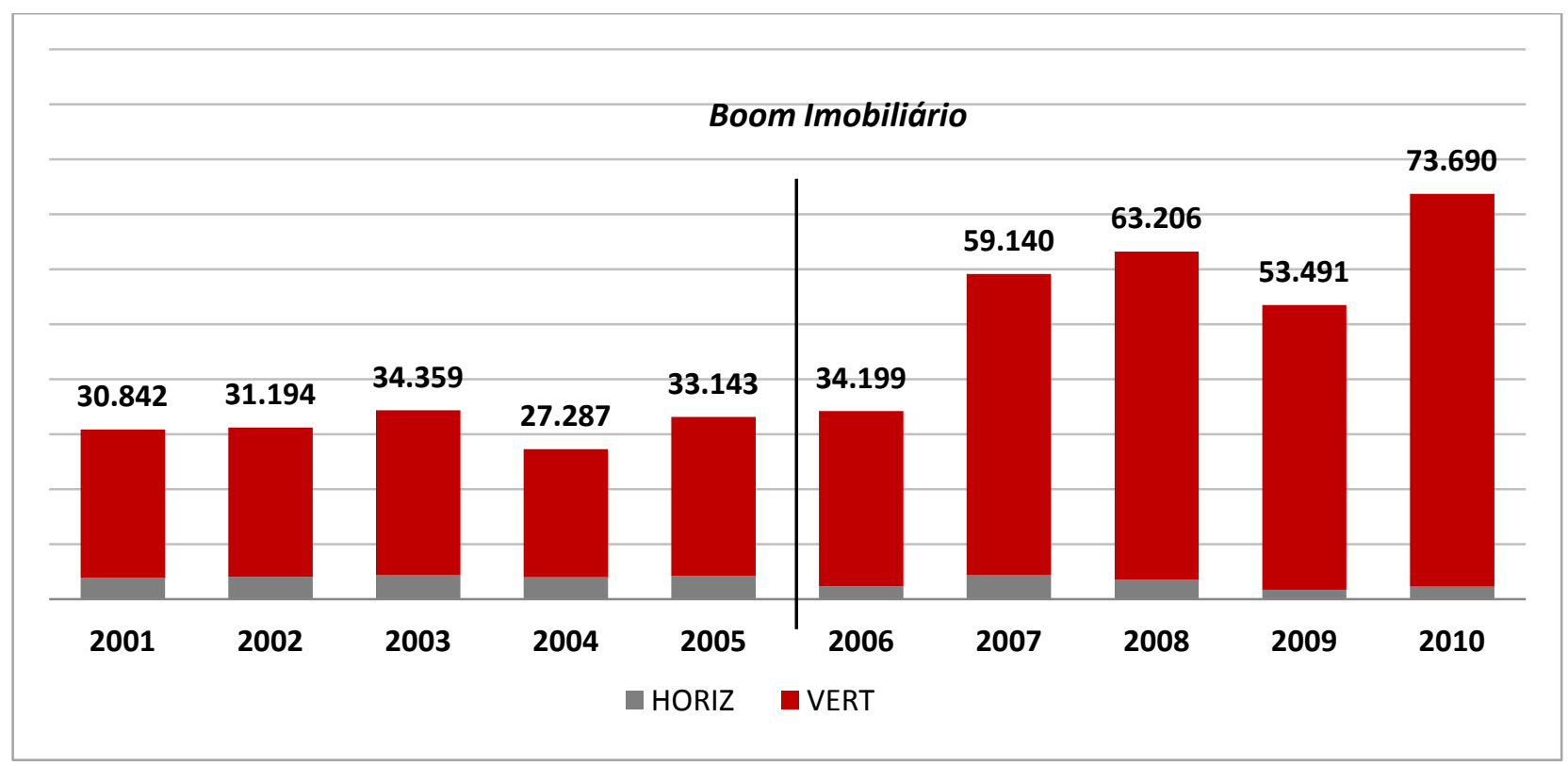

ELABORAÇÃO: Autor. FONTE: Base EMBRAESP

\footnotetext{
${ }^{36}$ Segundo Pesquisa Ibope, o mercado imobiliário foi responsável por $71 \%$ dos anúncios de jornal em 2009. (Fonte: Revista meio e mensagem/ Ibope Monitor)
} 
Partindo da apresentação dos principais agentes envolvidos na atividade imobiliária, buscaremos contextualizar esta nova dinâmica imobiliária, do despertar da demanda habitacional latente - origem do Boom -, passando pela capitalização e a revisão das estratégias de atuação dos promotores imobiliários, com a consolidação dos supercondomínios como o modelo de empreendimento a ser seguido.

\section{1 - PROMOTORES IMOBILIÁRIOS E SEUS PARCEIROS ${ }^{37}$}

Tipicamente, são quatro os principais agentes que participam da realização de um empreendimento imobiliário: o agente incorporador, também denominado promotor imobiliário, responsável pela montagem e gestão do negócio imobiliário; o agente construtor, responsável pela construção física da edificação; o agente "comercializador", responsável por intermediar a venda das UHs entre comprador final e o incorporador e; o agente financeiro, responsável pela disponibilização de capital, sob forma de linhas de crédito, tanto para o incorporador, para a construção do empreendimento (financiamento a produção), como para o comprador final, para que este financie o valor do imóvel (financiamento a pessoa física). Usualmente estes seriam representados pelas empresas incorporadoras, empresas construtoras, empresas imobiliárias e bancos, públicos e privados, respectivamente. A este quadro poderiam adicionar ainda, escritórios de arquitetura e engenharia, consultores, agências de publicidade, donos de terra, grupos financeiros, etc..

\footnotetext{
${ }^{37}$ Em referência ao título do terceiro capítulo do livro escrito por MILLES (2007).
} 
QUADRO 2: ORGANOGRAMA DO MERCADO IMOBILIÁRIO FORMAL.

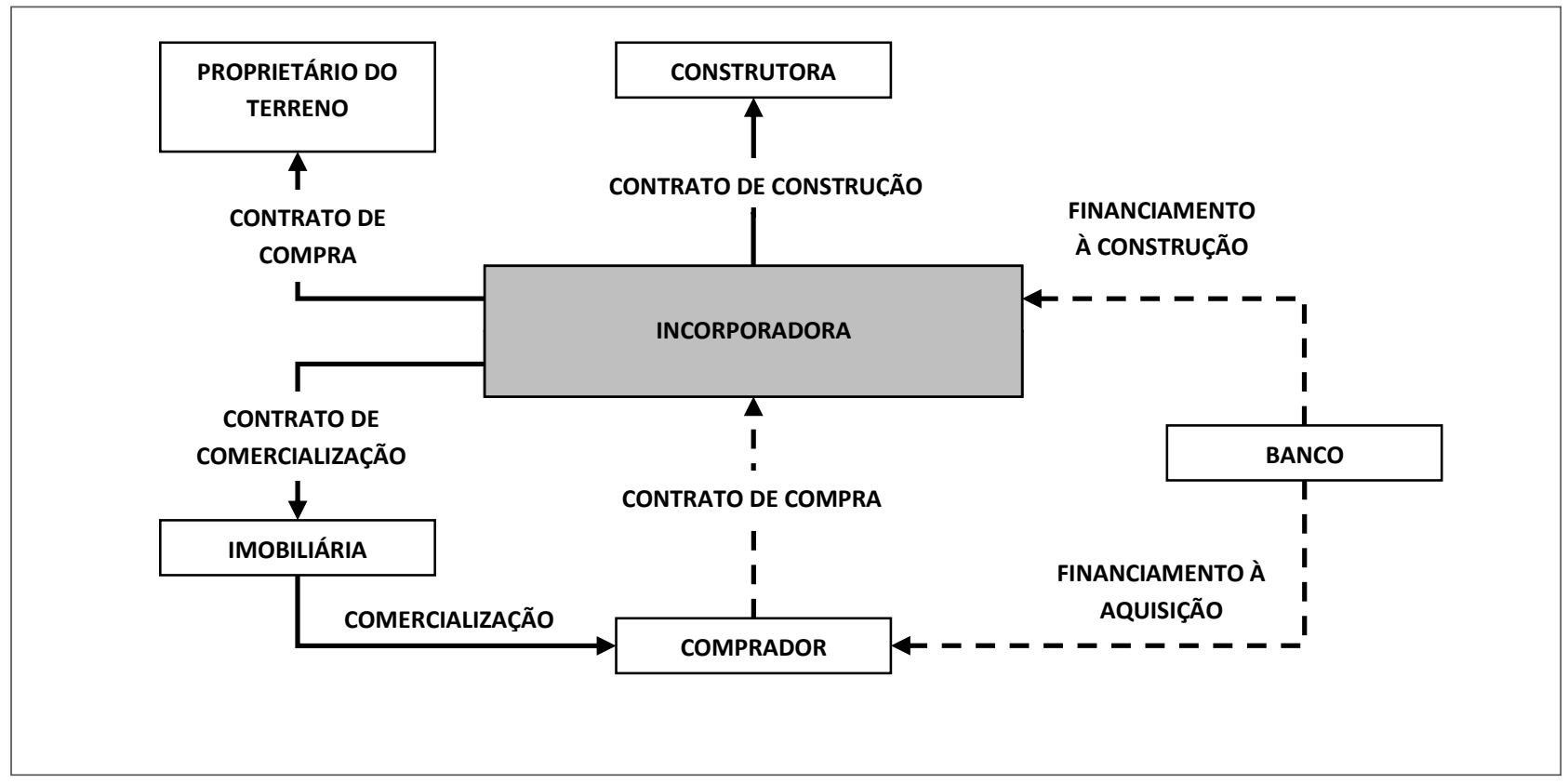

ELABORAÇÃO: Autor.

Com exceção do agente financeiro, costumeiramente estes agentes são abordados de maneira simplista, como "construtoras". Em parte, esta generalização se deve ao fato de que na maioria das vezes uma mesma empresa desempenhe o papel de dois ou mais agentes. Empresas construtoras geralmente se tornam incorporadoras e vice-e-versa. Exemplo destas são Cyrela, Gafisa, Rossi, Mrv, Trysul, PDG, etc.. Já na década de 1990, tornou-se comum que a empresa incorporadora também exercesse o papel de agente financeiro, frente a indisponibilidade de crédito imobiliário, oferecendo o financiamento do imóvel direto ao comprador. Recentemente, durante o Boom imobiliário, incorporadoras criaram suas 
próprias empresas de vendas (ou houses, como são conhecidas no setor) focadas na comercialização de seus produtos: a Cyrela criou a Seller (segmento de padrão alto) e a Selling (segmento econômico).

Estes agentes não só desempenham papéis diferentes como têm interesses divergentes. Enquanto o incorporador sempre buscará a construtora que construa a edificação pelo menor preço, a construtora buscará oferecer o seu serviço pelo maior valor, garantindo uma margem de lucro maior. $\mathrm{Na}$ prática, convém analisá-los de forma individualizada, como sugere Smolka (1987, p.47), entendendo o agente incorporador enquanto o promotor imobiliário, e os outros agentes, enquanto terceirizados deste. Desta forma, quando uma empresa construtora decide por montar o negócio imobiliário, mobilizando os outros agentes e assumindo os riscos da operação, ela estará atuando como agente incorporador, e não como agente construtor, mesmo que esta seja a sua natureza.

O termo promotores imobiliários é geralmente utilizado de forma abrangente para indicar o grupo de agentes privados que promovem a atividade imobiliária. Ainda que o termo não encerre um grupo rígido, variando segundo o contexto, o autor e do enfoque da análise ${ }^{38}$, o termo se refere, em sua essência, ao agente incorporador ou developer ${ }^{39}$, seu equivalente em língua inglesa - sentido que adotaremos neste trabalho.

\footnotetext{
${ }^{38}$ Fix (2007), referenciando Topalov (1974), utiliza o termo promotores imobiliários para denominar os "agentes econômicos voltados a produção do meio ambiente construído, que procuram influir no funcionamento do mercado, no valor dos imóveis, nas decisões sobre os investimentos públicos e privados." (p.24), sugerindo um grupo que inclui desde as empresas incorporadoras, aos donos de terra, grupos financeiros, aos fundos de investimentos imobiliários, aos fundos de pensões, às empresas de consultoria, etc..

${ }^{39} \mathrm{O}$ termo developers é mais abrangente que o termo incorporador, ao contemplar as diferentes modalidades de promoção imobiliária. O termo incorporador deriva de "incorporação imobiliária", instrumento legal necessário apenas para
} 
Neste trabalho, o enfoque recai sobre os promotores imobiliários, "responsáveis pelo espaço criado e como este funcionará durante a vida de um projeto" (MILLES, 2007, p.40, tradução nossa). É o agente originador. Dispondo de equipes "enxutas", mobilizam e atendem os diversos atores envolvidos (públicos e privados). São aqueles que definem o produto imobiliário, desde a escolha do terreno, aos projetos de arquitetura, de paisagismo e de decoração, segundo a lógica financeira que os norteia. Cabe a eles identificar e explorar as oportunidades que o mercado apresenta e traduzi-las em empreendimentos que ofereçam oportunidades de valorização do capital incorporador ${ }^{40}$ (próprio ou de terceiros).

Durante o Boom, foram responsáveis por canalizar os recursos disponibilizados pelo mercado de capitais no mercado imobiliário. Medida que exigiu a reestruturação destas e dos seus agentes parceiros. Tiveram seu porte financeiro aumentado exponencialmente, verificado pelo surgimento das empresas incorporadoras bilionárias. E, com isso, a concentração do poder de produção do espaço construído nas mãos de um grupo relativamente reduzido. Em última análise, definiram as estratégias que levaram a revisão do produto imobiliário e, a consolidação dos supercondomínios como um modelo de empreendimento a ser seguido.

empreendimentos onde a comercialização das unidades se dá antes de sua construção. Desta definição, não participariam as empresas que comercializam unidades após construídas e as empresas loteadoras.

${ }^{40}$ Smolka (1987, p.47) define o capital incorporador como "aquela fração do capital que se valoriza pela articulação destes diversos serviços contratados" ou, alternativamente, como o capital utilizado para a aquisição do terreno [ matéria- prima] "com a finalidade de valorizá-lo na alteração do uso, ou seja, capital que investe nas bases em que rendas fundiárias são formadas". 
QUADRO 3: PRINCIPAIS INCORPORADORAS, CONTRUTORAS E IMOBILIÁRIAS ATUANTES NA RMSP, entre 2008 e 2011.

\begin{tabular}{lll}
\hline INCORPORADORAS & CONTRUTORAS & IMOBILIÁRIAS \\
Agra & Brookfield & Abyara Brokers \\
Brookfield & Company & Avance \\
Camargo Correa & Cury & Coelho da Fonseca \\
Cyrela & Cyrela & DelForte \& I.Price \\
Even & Even & Elite Brasil \\
EzTec & Ez Tec & Even \\
Gafisa & Gafisa & Exclusiva \\
Goldfarb & Goldfarb & Fernandez Mera \\
Helbor & ISO & Habitcasa \\
Klabin Segall & Klabin Segall & Iprice \\
MAC & MAC & Itaplan \\
MRV & MRV & Lopes \\
PDG Realty & PDG Realty & Plus \\
Rossi & Tecnisa & Tenda \\
Tecnisa & Tenda & \\
Tenda & Tibério & \\
Tibério & Trisul & \\
Trisul & & \\
ELABORAÇÃO: Autor. FONTE: Ranking Prêmio Top Imobiliário (15a, 16ミ, 17a e e 18a edições). &
\end{tabular}




\section{2 - O DESPETAR DA DEMANDA LATENTE}

A origem do boom imobiliário residencial observado no Brasil a partir da segunda metade da década de 2000 está no despertar de parte da demanda habitacional latente, viabilizando o acesso ao produto imobiliário para setores um pouco mais amplos da sociedade. O cenário econômico-financeiro favorável inseriu no mercado residencial formal uma classe média ávida pela casa própria que, da noite para o dia, ganhou título de "consumidor potencial". A este despertar estão associados três fatores principais: (I) o aumento da renda e a diminuição da desigualdade econômica; (II) revisão do marco jurídico imobiliário, com a introdução do patrimônio de afetação e da alienação fiduciária; e (III) o crescimento do crédito habitacional , com a progressiva flexibilização dos parâmetros de financiamento.

Enquanto o aumento da renda e a diminuição da desigualdade econômica aumentaram a capacidade de compra da população, a flexibilização dos parâmetros de financiamento aplicados pelas instituições financeiras e a revisão do marco jurídico imobiliário aumentaram a sua capacidade de endividamento (o segundo ao reduzir os riscos assumidos pelo credor), movimentos que juntos qualificaram parte da demanda habitacional latente e promoveram um maior acesso ao mercado imobiliário formal. 


\section{O AUMENTO DA RENDA E A DIMINUIÇÃO DA DESIGUALDADE ECONÔMICA}

As leituras positivas da década de 2000, especificamente da gestão Lula (2003 - 2010), têm sido favorecidas pelo contraste que guardam com as décadas de 1980 e 1990 - a primeira recordada como a década perdida ${ }^{41}$ para os países da América Latina. Em grande parte, por que o crescimento econômico observado foi acompanhado de uma redução na desigualdade econômica, isto é, o crescimento da renda dos mais pobres esteve acima da elevação da renda média da população, o chamado crescimento própobre ${ }^{42}$, como mostra a série histórica do coeficiente de $\mathrm{GINI}^{43}$.

Entre as principais causas associadas à redução da desigualdade econômica estão a valorização da mão de obra de base e o crescimento do mercado de trabalho. Na RMSP, a Taxa de Ocupação (percentual da População Economicamente Ativa (PEA) empregada), alcançou 94,7\% em dezembro de 2010 contra 85\% em outubro de 2003. O crescimento dos trabalhadores com carteira assinada superou em cerca de $18 \%$ o crescimento da População Ocupada (P.O.) entre 2004 e 2010. No mesmo período, o salário mínimo teve um crescimento real ${ }^{44}$ de aprox. $59 \%$.

\footnotetext{
${ }^{41}$ Curiosamente, o termo lost decade tem sido freqüentemente utilizados para referir-se a economia americana na década de 2000.

${ }^{42}$ Terminologia utilizada pelo IPEA e conceituada por Son em "A note on pro-poor groth"(2004).

${ }^{43}$ O Coeficiente de GINI, é acompanhado pelo Programa das Nações Unidas para o Desenvolvimento (PNUD) e no Brasil, é apurado em parceria com o IBGE e com o IPEA, desde 1976. Ao contrário do PIB per capita, que não pondera a diferença de ganhos entre a população, o coeficiente apresenta o grau da eqüidade na distribuição de renda, sendo "0", quando não há desigualdade, a "1", quando a desigualdade é máxima (um único indivíduo concentra toda a renda). No Brasil, o coeficiente atingiu o auge em $1989(0,636)$ e manteve-se estável ao longo da década de 1990 ao redor de 0,60. A partir da década de 2000 descreveu uma curva descendente constante, indo de 0,596 em 2001 a 0,530 em 2010, retornando aos valores de $1960(0,536)$.

${ }^{44}$ Salário mínimo deflacionado pelo INPC. Fonte: IPEA
} 
GRÁFICO 2: EVOLUÇÃO (\%) TAXA DE OCUPAÇÃO * NA RMSP.

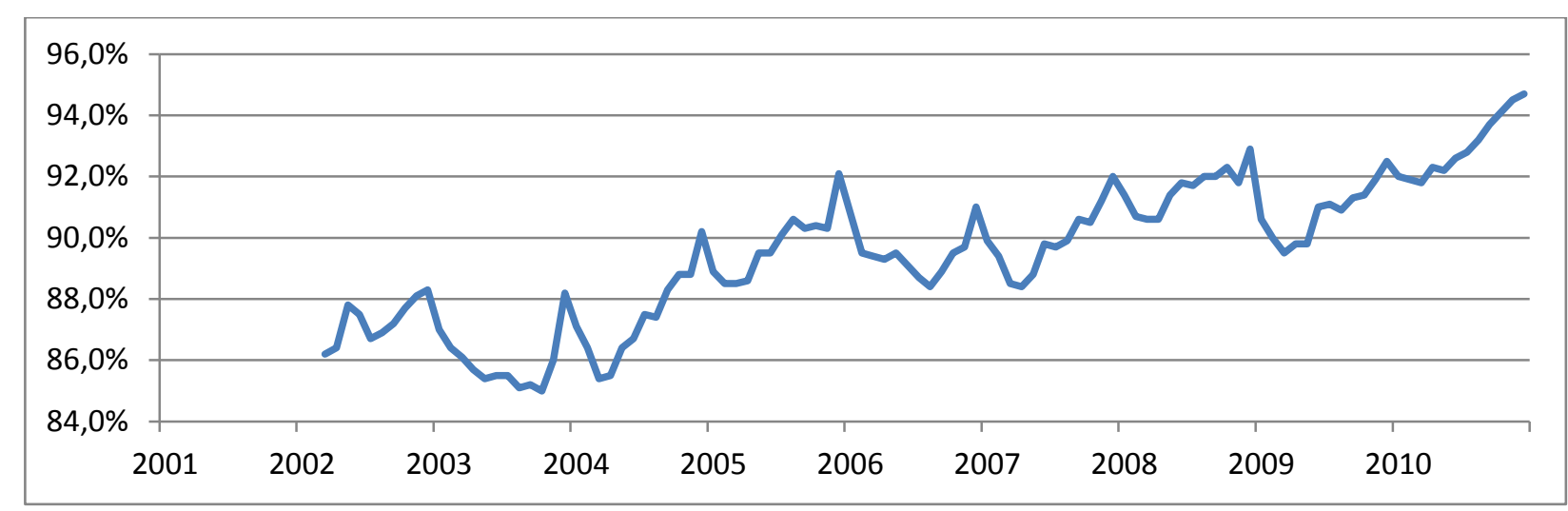

(* Taxa de Ocupação = População Ocupada (P.O.)/ População Economicamente Ativa (P.E.A.) Fonte: IBGE.

Elaboração: Autor Fonte: IPEA

GRÁFICO 3: PIB per capita (preços 2011) - série histórica/ US\$ de 2011 (mil)

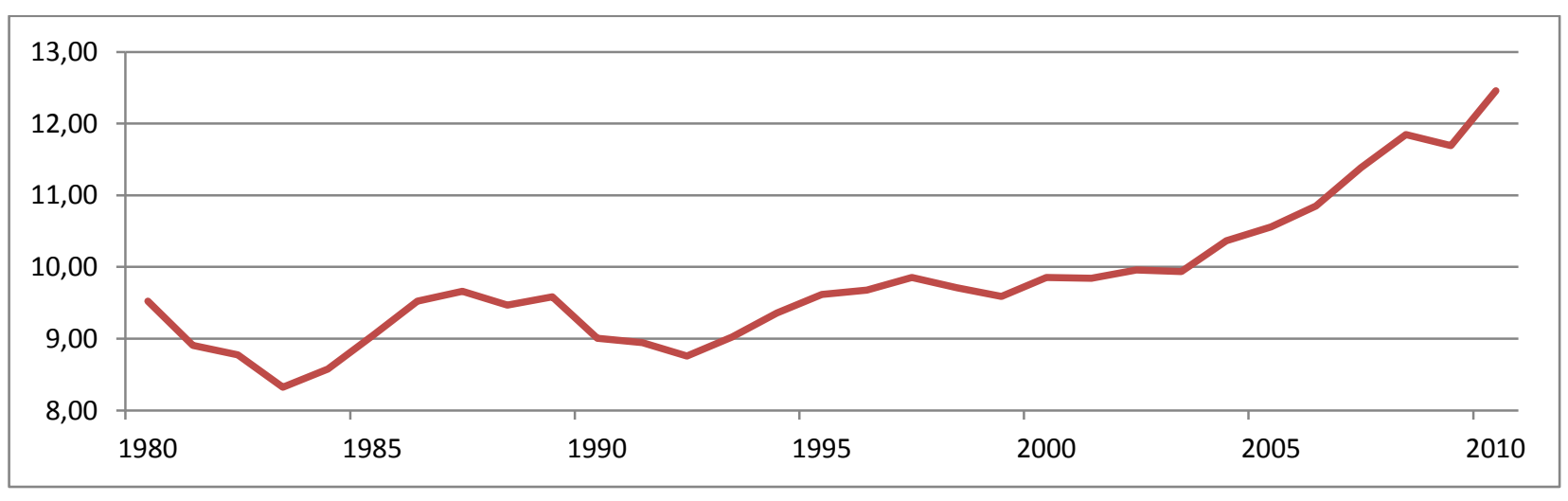

Elaboração: Autor Fonte: IPEA 
Os programas de transferência de renda desenvolvidos pelo poder público, a exemplo do Bolsa Família ${ }^{45}$, também têm sido considerados importantes neste processo. Entretanto, análises quantitativas recentes têm colocado em dúvida a sua efetividade, e tem apontado o crescimento do grau de instrução da população como uma das causas do crescimento pró-pobre (MARINHO; LINHARES; CAMPELO; 2011).

A respeito da redução da desigualdade econômica, o economista Marcelo Neri, do Centro de Políticas Sociais da Fundação Getúlio Vargas (FGV), mostra que entre 2001 e 2009, os 10\% mais pobres da população tiveram um aumento de renda em $69,08 \%$ enquanto os $10 \%$ mais ricos um aumento de 12,80\%. Em "De volta ao País do Futuro", título aludindo à célebre frase de Zweig ${ }^{46}$, o autor discute o contexto macroeconômico brasileiro nesta última década. O autor finaliza o texto concluindo que enquanto a década de 1990 pode ser lembrada como a década da estabilidade, em razão do equilíbrio financeiro alcançado após o Plano Real (1994), a década de 2000 será lembrada como a década da redução das desigualdades sociais.

\footnotetext{
${ }^{45}$ Criado no governo Lula, em 2003 e integrado ao programa Brasil sem Miséria em 2011, o Bolsa Família é um programa de transferência de renda que beneficia famílias em situação de pobreza e extrema pobreza. Em contrapartida as famílias devem garantir que os filhos mantenham-se na escola e vacinados.

${ }^{46}$ O bordão "Brasil, país do futuro", título do livro escrito em 1941 pelo austríaco exilado no Brasil Stefan Zweig, tornou-se popular ao expressar um sentimento nacionalista e de progresso que envolvia o país na época.
} 
GRÁFICO 4: VARIAÇÃO PERCENTUAL DA RENDA ACUMULADA NO PERÍODO (2001-2009)/ POR DÉCIMOS DA POPULAÇÃO

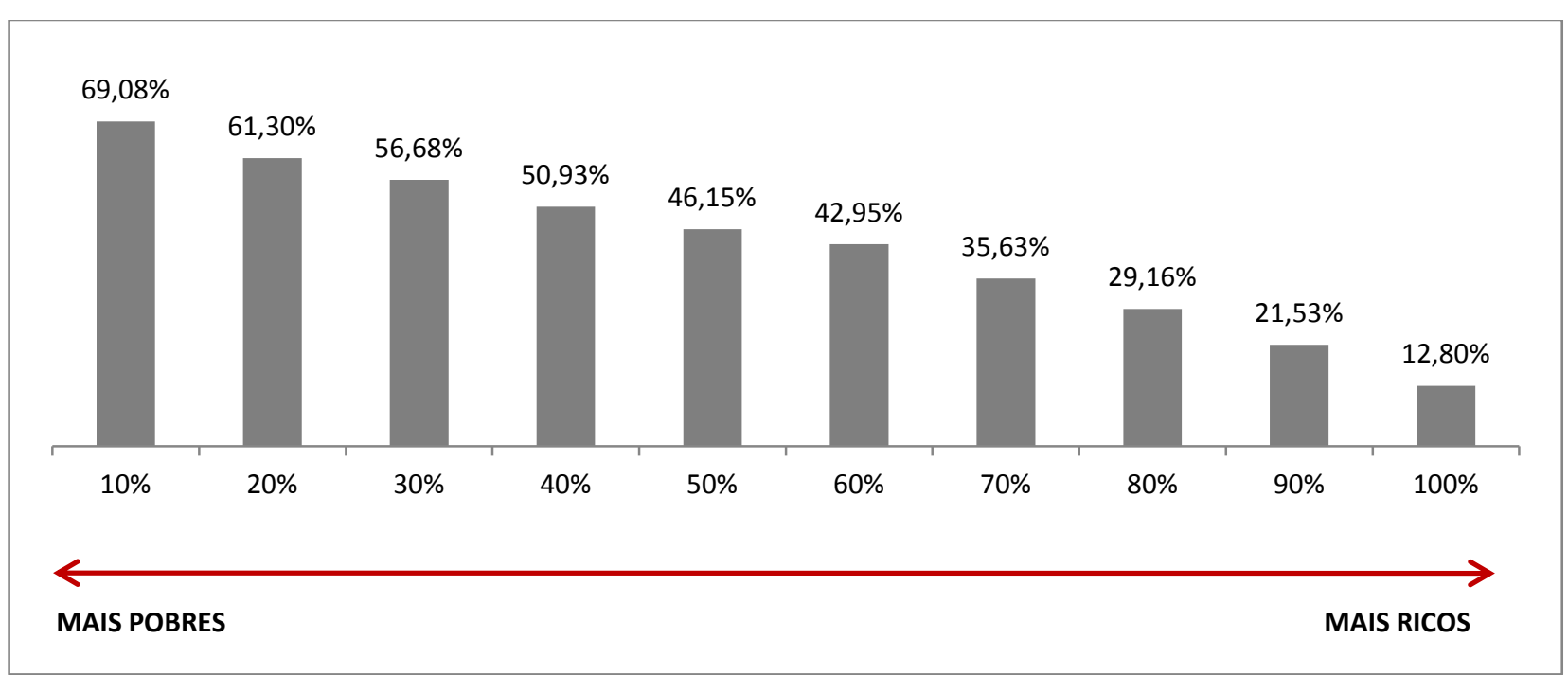

FONTE: CPS/ FGV a partir dos microdados dados PNAD/ IBGE

Na mídia, o assunto tem sido abordado como o crescimento da classe $C$, representada pela população com renda familiar entre $\mathrm{R} \$$ 1.126,00 e R\$ 4.854,00 (Outubro de 2010 - estratificação da FGV), que entre 2003 e 2009 cresceu 34,32\%, e alcançou 50,5\% da população brasileira. Em abril de 2008, a revista Veja estampou na capa a frase "A classe dominante: com 86 milhões de brasileiros, a classe C torna-se a maior do país. Saiba como esse fenômeno populacional e de mercado vai revolucionar o Brasil” (grifo nosso), inaugurando uma série de publicações populares tratando de desvendar os padrões 
de consumo da nova classe média: "A classe média que você precisa conhecer", (Época Negócios, nov. 2009), “A classe C cai na rede” (Exame, Nov. 2010), “Nunca fomos tão felizes” (Istoé, ago. 2010), etc..

Apesar do alarde, para o mercado imobiliário formal, a capacidade de financiamento da maior parte da classe $C$ ainda é insuficiente para permitir aquisição de imóveis e configura demanda latente. Este cenário mudou temporariamente com a introdução do PMCMV em 2009, que na RMSP, reverteu-se em uma onda de lançamentos imobiliários "econômicos", principalmente na zona leste de São Paulo e na região do $A B C$, Guarulhos, e Cotia, onde se encontravam os terrenos mais baratos.

QUADRO 4: POPULAÇÃO POR FAIXA DE RENDA, BRASIL

\begin{tabular}{lcccc}
\hline & \multicolumn{2}{c}{2003} & 2009 \\
\hline CLASSE A (ACIMA R\$ 6.329,00) & 6.345 .080 & $3,62 \%$ & 9.598 .716 & $5,10 \%$ \\
\hline CLASSE B (DE R\$ 4.854 À R\$ 6.329,00) & 6.977 .329 & $3,98 \%$ & 10.369 .023 & $5,51 \%$ \\
\hline CLASSE C & 65.871 .283 & $37,56 \%$ & 94.934 .828 & $50,45 \%$ \\
\hline CLASSE D & 46.884 .477 & $26,73 \%$ & 44.453 .034 & $23,62 \%$ \\
\hline CLASSE E & 49.319 .851 & $28,12 \%$ & 28.838 .782 & $15,32 \%$ \\
\hline TOTAL & $\mathbf{1 7 5 . 3 9 8 . 0 2 0}$ & $\mathbf{1 0 0 , 0 0 \%}$ & $\mathbf{1 8 8 . 1 9 4 . 3 8 3}$ & $\mathbf{1 0 0 , 0 0 \%}$
\end{tabular}

FONTE: CPS/ FGV a partir dos microdados dados PNAD/ IBGE.

Menos divulgado foi o crescimento das classes A e B, principal segmento de atuação dos promotores imobiliários. Representando uma minoria da população, o crescimento destas faixas indica efetivamente o novo mercado que se apresentava aos promotores imobiliários. Entre 2003 e 2009, a 
participação da classe A, com renda familiar acima de $\mathrm{R} \$$ 6.329,00, (aproximadamente U\$ 3.000,00 em DEZ/2012) cresceu 40,99\% (3,25 milhões) e da classe B, com renda familiar entre $R \$ 4.854,00$ e $R \$$ $6.329,00$, cresceu $38,51 \%$ (3,39 milhões). Isto significa que em população (considerando o crescimento populacional) o mercado para os segmentos das classes "A"e "B" cresceu 49,88\% em apenas 7 anos.

Em março de 2008, a pesquisa Lar, doce lar, parte da pesquisa O Observador Brasil 2008, realizada pela Cetelem com o Instituto de Pesquisa Ipsos, procurava associar hábitos de moradia, segundo as classes sociais. Atestando o positivismo que marcou o mercado no período, a pesquisa apurou que $38 \%$ das famílias das classes A/B e $28 \%$ da classe C tinham interesse em adquirir um imóvel. Posteriormente, pesquisa IBOPE realizada em 2010 afirmava que 19\% da classe C brasileira [o que naquele momento correspondia a mais de $50 \%$ da população] planejavam adquirir um imóvel nos próximos seis meses. ${ }^{47}$

\section{A REVISÃO DO MARCO JURÍDICO DA PROPRIEDADE IMOBILIÁRIA: A ALIENAÇÃO FIDUCIÁRIA E O} PATRIMÔNIO DE AFETAÇÃO

Com o objetivo de "promover o financiamento imobiliário em geral, segundo condições compatíveis com as da formação dos fundos respectivos" (Art. 1), a promulgação da Lei 9.514 em 1997 (posteriormente alterada pela M.P. 2.223/01 e pela Lei 10.931/04) instituiu a alienação fiduciária para bens imóveis, instrumento que deu maior segurança jurídica às instituições financeiras. Para estas, disponibilizar contratos de financiamento imobiliário representava um grande risco uma vez que o imóvel

\footnotetext{
${ }^{47}$ Agência Estado, 6 de outubro 2010: Ibope corrige: 19\% da Classe C planeja comprar uma casa.(CASTRO, 2010)
} 
hipotecado, lastro do contrato de financiamento, só poderia ser recuperado pelo banco no caso de inadimplência após a apreciação do Poder Judiciário: processo custoso e demorado, durante o qual o proprietário original, ainda que devedor, gozava de pleno direito sobre a propriedade. Na alienação fiduciária a venda ocorre com a reserva de domínio, isto é, o vendedor conserva a propriedade até que a dívida tenha sido quitada, dispensando a adoção da hipoteca. No caso de inadimplência, a reintegração de posse ocorre através de procedimento extrajudicial, cabendo ao oficial do Cartório Imobiliário dar andamento ao processo, reduzindo para poucos meses a reintegração de posse. A introdução da alienação fiduciária beneficiou as instituições financeiras, que se viram maior dispostas a oferecer novas linhas de financiamento mais acessíveis, e também a população de média e baixa renda, que oferecendo riscos reduzidos, passou a integrar o mercado consumidor de financiamentos imobiliários.

Além da progressiva substituição da hipoteca pela alienação fiduciária, a edição da Medida Provisória no 2.221/01, que instituiu o patrimônio de afetação, posteriormente revogada pela Lei 10.931/04 (Patrimônio de Afetação) foi fundamental para modernizar o marco regulatório do setor. Segundo a lei:

Art. 31-A. A critério do incorporador, a incorporação poderá ser submetida ao regime da afetação, pelo qual o terreno e as acessões objeto de incorporação imobiliária, bem como os demais bens e direitos a ela vinculados, manter-se-ão apartados do patrimônio do incorporador.

Ao isolar o patrimônio do empreendimento ao do incorporador, a lei evita que os recursos de uma obra sejam redirecionados a outra, causando uma dívida futura ou mesmo impedindo a sua entrega. 
O patrimônio de afetação só será extinguido quando a obra for entregue aos seus proprietários finais. Em contrapartida, as incorporadoras que sujeitarem seus projetos ao regime de afetação recebem incentivos tributários, justificados também pela redução dos riscos das operações.

Em parte a lei procurou evitar que casos como o da incorporadora e construtora Encol voltassem a ocorrer. Uma das maiores empresas do setor na década de 1990 foi à falência em 1999 após uma crise de inadimplência. Como não havia separação entre os patrimônios, 796 empreendimentos foram paralisados, deixando 42 mil mutuários em todo o Brasil aguardando a entrega dos respectivos $a_{\text {apartamentos }}^{48}$. A situação se estendeu por anos na justiça, penalizando os proprietários e também o mercado residencial como um todo, ao rotular negativamente a venda de imóveis antes que fosse iniciada a construção, a chamada venda do "imóvel na planta", principal forma de comercialização de imóveis no Brasil.

A exemplo da CEF, que no início de 2005 oferecia prazos de financiamento máximos de 17 anos para os que optassem pela garantia hipotecária e 20 anos para os contratos sob regime de alienação fiduciária, a revisão da legislação reduziu o risco assumido pelo credor, permitindo que as instituições financeiras, reduzissem os pré-requisitos exigidos para pleitear um financiamento imobiliário e abriu possibilidades para o desenvolvimento de novos produtos financeiros, estimulando a entrada dos bancos no segmento econômico, antes evitado devido à crença na maior inadimplência.

\section{O CRESCIMENTO DO CRÉDITO HABITACIONAL}

$\overline{48}$ Folha de São Paulo, 24 de Maio de 1997: Encol tenta acordo para terminar prédios. (ESPOSITO, 1997). 
Desde $1964^{49}$, a política habitacional brasileira vem sendo conduzida pelo Governo Federal através do Sistema Financeiro da Habitação (SFH). Com operações lastreadas nos recursos do Sistema Brasileiro de Poupança e Empréstimo (SPBE) e do Fundo de Garantia do Tempo de Serviço (FGTS), a atuação do Banco Nacional da Habitação (BNH) - que permaneceu como órgão central até 1986 - dividiuse em duas frentes: oferecer linha de crédito aos empresários e construtores, responsáveis por comercializar as unidades habitacionais e repassar os contratos de financiamento ao banco e com recursos do FGTS, construir casas de interesse social. Entre 1972 e 1982 o SFH respondeu pelo financiamento de $80,8 \%$ dos edifícios residenciais lançados (SALGADO, 1987, p.58). No período de auge, entre 1976 e 1982, financiou cerca de 400 mil unidades por ano (SANTOS, 1999, p.17).

Em meados da década de 1980, o modelo de política habitacional baseado no SFH entrou em colapso. A aceleração da inflação, o aumento da inadimplência, e o exercício de um sistema de correção monetária incapaz de cobrir os juros dos saldos devedores existentes, mostraram que o sistema não conseguia o retorno de caixa que the permitisse conceder novos financiamentos em volume expressivo (SIMONSEN, 1991, p.28). Em 1988 o BNH foi extinto e suas responsabilidades repassadas a Caixa Econômica Federal (CEF).

Com o fim do $\mathrm{BNH}$, perdeu-se uma estrutura de caráter nacional que, mal ou bem, tinha acumulado enorme experiência na área, formado técnicos e financiado a maior produção habitacional da história do país. [...] A Caixa Econômica Federal - um banco de primeira linha - tornou-se o agente financeiro do SFH, absorvendo precariamente algumas das atribuições, pessoal e acervo do agora antigo BNH. A regulamentação do crédito habitacional passou para o Conselho Monetário Nacional, tornando-se, de modo

\footnotetext{
${ }^{49}$ Lei no 4.380 de 21 de agosto de 1964.
} 
definitivo, um instrumento de política monetária, o que levou a um controle mais rígido do crédito, dificultando e limitando a produção habitacional. O financiamento minguou, ao mesmo tempo em que os problemas de moradia da população urbana se tornaram dramáticos, agravados pelo empobrecimento que marcou as décadas de 80 e 90. BONDUKI (2008, p.75-76)

A insuficiência da política habitacional do Brasil foi relatada pelo governo federal nos documentos da Política Nacional de Habitação (1996), advertindo que, durante trinta anos o SFH proveu apenas 5,6 milhões do total de 31,6 milhões de novas moradias produzidas no país. (SANTOS, 1999, p.22). O descompasso entre a produção de habitação e a demanda habitacional pôde ser observado pela explosão do mercado imobiliário informal na RMSP: "a população da área metropolitana cresceu 22,9\% entre 1980 e 1991 e neste mesmo período, a população favelada cresceu 120,64\%" (MEYER, GROSTEIN \& BIDERMAN, 2004, p.58).

No período seguinte, a escassez do crédito habitacional limitou a atividade imobiliária. Algumas empresas procuraram compensar a ausência dos bancos oferecendo elas próprias linhas de financiamento a seus compradores. A construtora e incorporadora Rossi destacou-se por lançar em 1992 o "Plano 100", oferecendo 100 meses para que o comprador amortizasse sua dívida diretamente com a construtora. Contudo, as taxas e prazos oferecidos pelos promotores imobiliários contrastavam com a capacidade financeira da maior parte da população. Enquanto a demanda habitacional latente crescia, os promotores concentram-se no desenvolvimento de empreendimentos para a classe alta, menos dependente dos instrumentos de financiamento, situação que perdurou até meados da década de 2000.

Este descompasso entre a necessidade por habitação e a inviabilidade econômica em oferecê-la ao 
consumidor potencial fez com que, por décadas, o número de unidades habitacionais produzidas pelo mercado formal fosse sequer suficiente para promover a renovação do estoque existente (SMOLKA \& BIDERMAN, 2010).

A retomada do crédito imobiliário veio sob forma de novas linhas de financiamento lançadas no mercado, inovando ao ampliar o percentual financiável do valor do imóvel, reduzir as taxas de juros e alargar os prazos para a quitação; ampliando o valor máximo financiável ao mutuário.

No início de 2005, após 13 anos de sobreaplicação, a CEF retomou a concessão de crédito imobiliário com recursos do SBPE. Na época, o banco foi proibido de realizar esse tipo de empréstimo pelo Conselho Monetário Nacional (CMN), que considerou alto o nível de endividamento da Caixa. (GANDRA, 2005). Como os financiamentos com recursos do FGTS estavam limitados a mutuários com renda familiar máxima de $R \$ 4.900$ e imóveis de até $R \$ 130.000,00$, a medida beneficiava diretamente a classe média. Segundo Jorge Mattoso, presidente da CEF daquele momento, a linha de crédito atendia um espaço "que os outros bancos privados vêm crescentemente ocupando". Com taxas de juros reduzidas (10\% a.a. a 12\% a.a.+ T.R.), a linha também inovava no prazo, estendido de 15 para 20 anos, e no percentual financiável, $80 \%$ do valor do imóvel, contra 70\% dos bancos privados. Em 2006, Bradesco, Santander Banespa, e Nossa Caixa também já ofereciam 20 anos.

A entrada da CEF no segmento da classe média entrava em atrito com os bancos privados que, com a progressiva redução das taxas de juros (SELIC, de 26,5\% (mar/2003) para 8,75\% (jul/2009), e redução dos riscos contratuais, interessavam-se cada vez mais pelo crédito imobiliário. Trabalhando também com recursos do SFH, os bancos privados começaram também uma progressiva redução das 
taxas de juros e prolongamento dos prazos. O crescimento das aplicações de recursos do FGTS e da caderneta de poupança, que saltaram de $\mathrm{R} \$ 5,8$ bilhões, em 2004, para $\mathrm{R} \$ \mathbf{8 3 , 1}$ bilhões, em 2010, garantiram, por hora, a sanidade do SFH e estimularam a "abertura" de mercado.

Em março de $2009^{50}$ foi lançado o programa habitacional do Governo Federal Programa Minha Casa Minha Vida (PMCMV). Com a finalidade de "criar mecanismos de incentivo à produção e à aquisição de novas unidades habitacionais pelas famílias com renda mensal de até 10 (dez) salários", teve como meta inicial de um milhão de unidades habitacionais (posteriormente revista para dois milhões até final de 2014). Desenvolvido em colaboração com representantes da indústria da construção (lê-se incorporadores, a exemplo de Cyrela, Rossi e MRV) a estratégia consistiu em mobilizar os agentes do mercado imobiliário formal, já estabelecidos e estruturados, na provisão de habitações econômicas.

Sob coordenação do banco público $\mathrm{CEF}^{51}$, dois foram os principais mecanismos criados para aumentar a capacidade de compra da população de baixa renda: subsídios e taxas de juros reduzidas, distribuídos gradativamente segundo os níveis de renda. Foram alocados $\mathrm{R} \$ 26$ bilhões para os subsídios, que chegaram a $\mathrm{R} \$ 23.000,00$ por imóvel, segundo localização e renda familiar.

Dividido em três segmentos de renda - "0 a 3", "3 a 6" e "6 a 10" salários mínimos - o programa definiu diferentes graus de participação dos promotores imobiliários. Na faixa de "0 a 3" salários mínimos, coube aos promotores imobiliários a prospecção dos terrenos e a construção das unidades, enquanto os governos municipais mobilizavam a demanda e promoviam a comercialização das unidades.

\footnotetext{
${ }^{50}$ Medida Provisória no 459, de 25 de março de 2009, convertida em Lei no 11.977 de 07 de julho de 2009.

${ }^{51}$ Bancos privados não foram diretamente envolvidos no programa Posteriormente o Banco do Brasil inaugurou a sua atuação no PMCMV por meio do empreendimento Marcco Sorocaba, incorporadora e construtora Plano e Plano (2010).
} 
Nesta faixa os principais beneficiados foram as construtoras. Nas faixas de "3 a 6" e "6 a 10" salários mínimos, o modelo de atuação seguiu o padrão de oferta e comercialização do mercado privado, desde a compra do terreno, a incorporação, comercialização e venda, beneficiando também incorporadoras e imobiliárias.

A criação do PMCMV foi declaradamente uma medida anticíclica, estimulando a demanda e o emprego. O final de 2008 foi marcado pelo impacto da crise americana no Brasil, paralisando o setor imobiliário. As ações das incorporadoras, que nos anos anteriores tinham proporcionado gigantescos lucros aos investidores, perderam $72 \%{ }^{52}$ de seu valor em poucos meses, processo seguido por demissões em massa nas grandes empresas ${ }^{53}$ do setor. Os segmentos de médio e alto padrão, foco da atuação, foram os principais afetados pelo clima de insegurança que envolvia crise. A criação do programa habitacional no início de 2009 serviu com um salva-vidas: "'Foi exatamente como pleiteamos', disse Rubens Menin, presidente da mineira MRV"54. Para a baixa renda, os benefícios oferecidos foram de tamanha ordem, que anularam possíveis receios decorrentes da crise global que se instalava.

Após dois anos, o PMCMV colecionava grandes números: mais de 933 mil unidades inscritas, $\mathrm{R} \$$ 29 bilhões em financiamentos comprometidos e margem de lucro das principais companhias do setor beirando 16\% ${ }^{55}$. Entretanto, em 2011 a efetividade e sustentabilidade do programa passou a ser questionada. Apesar do grande envolvimento das incorporadoras em 2009 e 2010, as dificuldades em se

\footnotetext{
${ }^{52}$ Folha Online, 29 de dezembro de 2008. Crise mundial gera perda de R\$ 871 bilhões na Bolsa brasileira. (FOLHA ONLINE, 2008).

${ }^{53}$ Folha Online, 06 de Novembro de 2008: Setor de construção civil começa a demitir. (WIZIACK, 2008).

${ }^{54}$ Valor Econômico, 26 de Março de 2009: Construtoras já projetam crescimento maior este ano. (AMBROSIO, 2009).

${ }^{55}$ Percentual estabelecido com base nos balanços das empresas de capital aberto do setor. Fonte: Website Fundamentos.
} 
manter as margens de lucro praticadas face aos preços limites estabelecidos pelo programa junto ao reaquecimento do segmento de padrão médio e alto, levaram as mesmas empresas a reduzirem em $50 \%{ }^{56}$ a participação dos produtos econômicos em seus portfólios para 2011.

A retomada do crédito habitacional pode ser observada pelo crescimento do número de unidades financiadas a partir de 2006. Historicamente, o Brasil conservou volumes de crédito imobiliário muito baixos em relação ao seu PIB. Segundo o Banco Central (2011), mesmo com o crescimento exponencial observado nesta década, o valor saltou de 1,2\% em 2001 para 4,1\% em abril de 2011. Porcentagem ainda muito inferior a de países desenvolvidos, como Holanda $(66,1 \%)$, Estados Unidos (70,3\%), e França $(39,8 \%)$, ou mesmo de vizinhos na América Latina, como Argentina e Chile.

GRÁFICO 5: EVOLUÇÃO NO № DE MORADIAS FINACIADAS* COM RECURSOS DO SBPE.

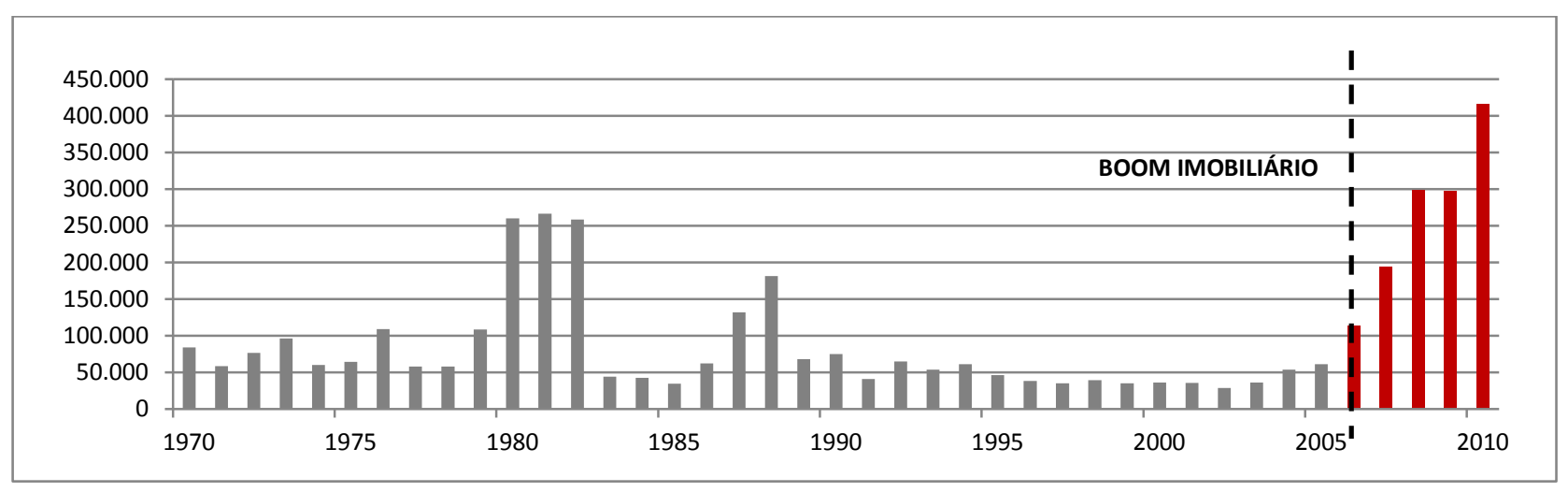

$\left(^{*}\right)$ Soma dos financiamentos para a Aquisição de Imóveis (novos e usados) e para a Construção

${ }^{56}$ Valor Online, 23 de março de 2011: Ex-vedete, segmento de baixa renda perdeu espaço no fim de 2010. (VALOR ONLINE, 2011). 
(que a partir 1998 inclui também Materiais de Construção, Reforma e Ampliação).

Elaboração: Autor Fonte: CBIC, Banco Central, ABECIP e CAIXA.

\section{3 - ESTRATÉGIAS PARA O CAPITAL INCORPORADOR}

Apesar do gigantesco potencial que o crescimento da demanda habitacional qualificada representou, o volume a ser ofertado contrastava com a capacidade produtiva limitada dos promotores

imobiliários, justificada por anos concentrados no segmento restrito de alta renda. Condição esta agravada pela vulnerabilidade do novo contexto: se por um lado, a expansão da demanda abriu uma janela de oportunidade, por outro, a dependência do sistema de financiamento habitacional e a grande sensibilidade da nova demanda a pequenas variações de preço no imóvel tornaram imprevisível a sustentabilidade deste novo mercado. Os promotores imobiliários sabiam que o desafio não era apenas produzir mais, mas produzir mais rápido.

Coube às incorporadoras, agente originador do negócio imobiliário, associar-se ao mercado financeiro que, ciente dos lucros potenciais (e superestimando a capacidades gerencial das empresas), rapidamente forneceu os recursos necessários para alavancar o setor.

\section{O SURGIMENTO DAS EMPRESAS BILIONÁRIAS}

A primeira empresa a debutar na Bovespa e ter as ações negociadas em pregão foi a Cyrela, captando R\$ 902 milhões em setembro de 2005. Em fevereiro de 2006, Rossi e Gafisa captaram $\mathrm{R} \$ 1,012$ bilhões e R\$ 927 milhões, respectivamente e, no mês seguinte, foi a vez da Company captar aproximadamente R\$ 209 milhões. No final de 2007 já eram 24 as empresas com as ações listadas na 
Bovespa, destacando-se a mineira MRV que, em julho de 2007, captou R\$ 1,193 bilhão, a maior captação do setor na Bovespa.

A procura foi liderada pelo capital estrangeiro. Segundo estimativas do mercado financeiro, ele representou $62 \%{ }^{57}$ para a Cyrela e $70 \%$ para a Rossi. Nas palavras de Walter Lafemina, presidente da Company, onde a participação do investidor estrangeiro aproximou-se de 60\%, "o mundo [havia eleito] o Brasil como o país da vez em termos de potencial imobiliário" ${ }^{58}$.

Este potencial de crescimento e de valorização dos imóveis no Brasil já era conhecido pelo mercado financeiro internacional no setor de serviços desde a década de 1990, quando os fundos de private equity estrangeiros investiram na criação do eixo de escritórios ao longo da Marginal do rio Pinheiros, processo investigado por FIX (2007) e HEPNER (2010).

No segmento residencial, onde a presença do credito habitacional é fundamental, a entrada do capital estrangeiro veio tardia, inicialmente vinculada a investidores já conhecidos do mercado imobiliário mundial. Em 1993, George Soros se associou a Elie Horn, proprietário daquela que viria a ser a construtora e Incorporadora Cyrela, por meio da empresa de investimentos Irsa. Para combater a ausência de crédito no país, o investidor participou ativamente na captação de recursos estrangeiros, considerado um dos principais fatores para que a incorporadora chegasse a líder do setor em 2008. Em 2005 foi a vez de Samuel Zell, gigante do mercado imobiliário americano. Por meio da Equity

\footnotetext{
${ }^{57}$ Valor Econômico, 7 de fevereiro de 2006: A nova onda imobiliária. (VALOR ECONÔMICO, 2006)

${ }^{58}$ O Globo, 30 de outubro de 2006: Brasil é o mercado de imóveis da vez. (D’ERCOLE, 2006)
} 
International Properties, desembolsou R\$ 135 milhões ${ }^{59}$ por $32 \%$ da construtora Gafisa. Naquele momento, Luiz Claudio Nascimento, presidente da Gafisa, justificou a venda: "Agora estamos com uma estrutura de capitais mais adequada para fazer a companhia crescer". Com a ajuda do investidor, em 2007, a Gafisa tornou-se a primeira empresa a ter ações comercializadas na Bolsa de Nova York (NYSE), arrecadando cerca de $\mathrm{R} \$ 1$ bilhão (somando cerca $R \$ 2$ bilhões com o valor captado em 2006): "Conseguimos alcançar um número maior de investidores estrangeiros de altíssima qualidade que não investem em empresas brasileiras listadas apenas na Bovespa", comemorou Duilio Caciolare, diretor de Relações com Investidores. "Foi num clima de febre, otimismo exagerado e desconhecimento de um setor ainda imaturo que 22 companhias levantaram R\$ 11 bilhões, numa primeira rodada" ${ }^{60}$.

A animação foi reforçada pela liquidez e valorização que as ações das incorporadoras apresentavam. Em outubro de 2005, as ações da Cyrela eram cotadas a R\$ 6,46; em dezembro de 2006 chegaram a R\$16,00 - um ganho de 140\% em um ano. A relevância das empresas do mercado imobiliário no mercado de capitais foi tamanha que, em janeiro de 2009, a BM\&F iniciou a divulgação e cálculo do novo índice IMOB (índice imobiliário) que tinha por base as empresas do setor.

No final de 2010, as sete maiores empresas do setor totalizavam R\$ 24 bilhões em patrimônio líquido. A PDG, líder do setor, fechou 2010 com patrimônio líquido de $\mathrm{R} \$$ 6,13 bilhões, valor nove vezes maior que em dezembro de 2006. A Cyrela, segunda maior empresa do setor, fechou 2010 com

\footnotetext{
${ }^{59}$ Valor Econômico, 10 de maio de 2005: Megainvestidor paga R\$ 135 milhões por 32\% da Gafisa. (MANDL, 2005).

${ }^{60}$ Valor Econômico, 18 de maio de 2011: Investidores estão de olho no caixa das construtoras. (D'Ambrósio, 2011).
} 
patrimônio líquido de $\mathrm{R} \$ 4.39$ bilhões, valor nove vezes maior que em março de 2005. Em 2010, as incorporadoras brasileiras representam 7 das 10 empresas de construção mais lucrativas na América. ${ }^{61}$

\footnotetext{
${ }^{61} \mathrm{G1}$, 2010, 6 de abril de 2010: Construtoras brasileiras têm 7 dos 10 maiores lucros das Américas em 2010 (G1, 2010)
} 
GRÁFICO 6: EVOLUÇÃO (R\$ BILHÕES) DO PATRIMÔNIO LÍQUIDO DAS SETE MAIORES INCORPORADORAS LISTADAS NA BOVESPA, EM 2012.

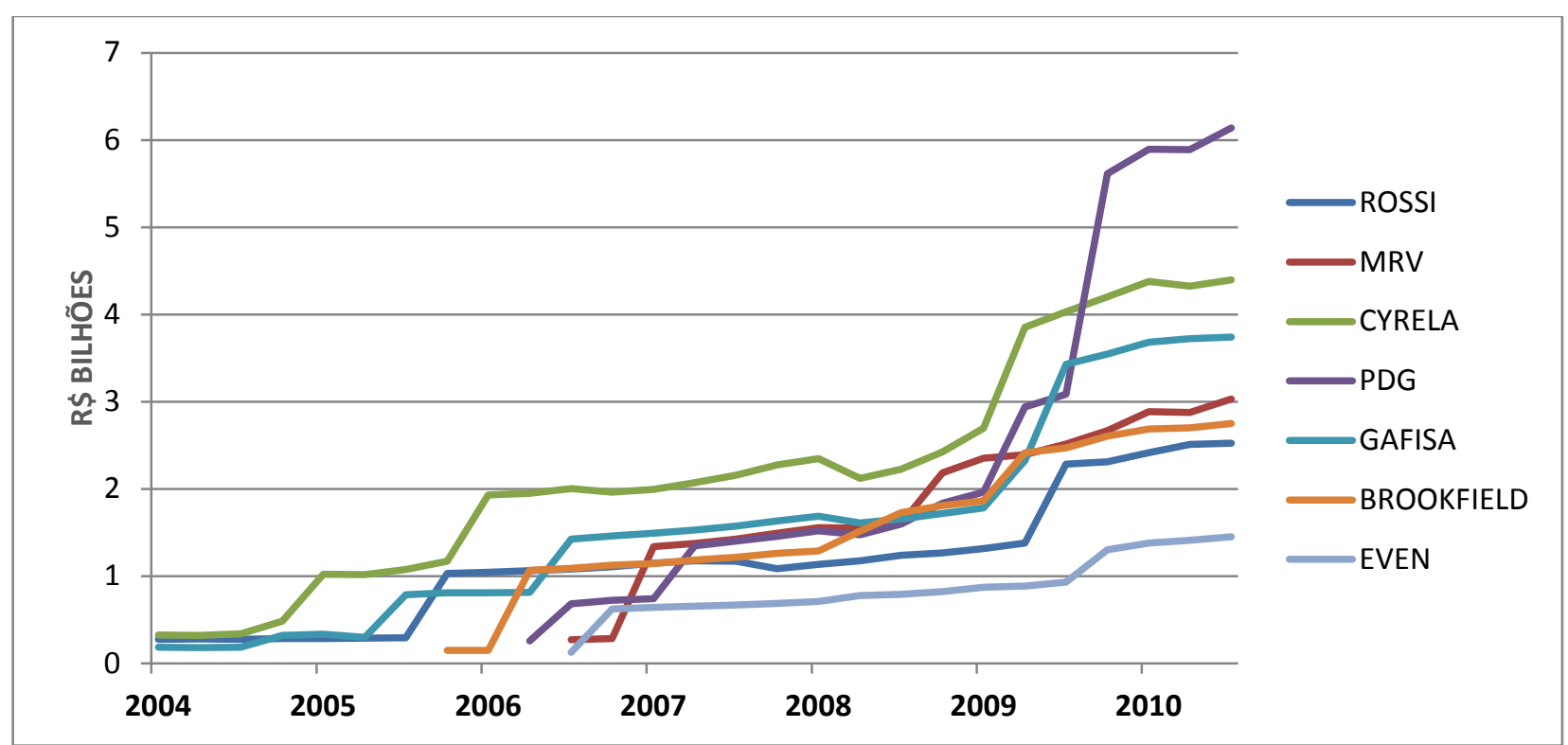

ELABORAÇÃO: Autor. FONTE: BOVESPA e website Fundamentus.

O movimento de abertura de capital, liderado pelas incorporadoras paulistas favoreceu a concentração do mercado: “Dos R\$ 1,2 bilhão que todo o setor lucrou em 2007, R\$ 902 milhões ficaram com [...] seis empresas (Abyara, Brascan, Company, Cyrela, Gafisa e Rossi.)" (BOECHAT, 2008), com destaque para Cyrela, Gafisa e Rossi, que juntas lucraram R\$ 666 milhões, pouco mais de $50 \%$ de todo o setor. Justificadas pela necessidade de crescimento rápido, distribuição geográfica, segmentação e apropriação da expertise, a capitalização inaugurou uma rodada de fusões, aquisições e joint ventures, acelerando ainda mais o processo de concentração do mercado. Deficiências na cadeia produtiva e 
conflito de interesses também levaram as incorporadoras a assumir internamente o papel desempenhado por outros agentes. Tradicionalmente, empresas que nasciam incorporadoras desenvolviam construtoras próprias, e vice-versa. A novidade ficou pela criação das empresas de comercialização ${ }^{62}$ (ou imobiliárias) e financeiras próprias.

A disponibilidade de capital incorporador deu início a uma corrida para a montagem dos estoques de terrenos: os chamados landbanks. O terreno é a matéria-prima do negócio imobiliário. Para as empresas, montar um landbank é necessidade primária, pois dele depende o volume de negócios futuros $^{63}$. Consequentemente, é medida utilizada pelo mercado para avaliar a saúde financeira da empresa. Entre o final de 2006 e o final de 2007, o landbank das 21 empresas incorporadoras listadas na Bovespa cresceu de R\$ 70 bilhões para R\$ 160 Bilhões de VGV potencial, um aumento de $130 \%$. (VEDROSSI, 2008, pag. 02)

A maturação do mercado levou a reestruturação do setor. Empresas de vendas (imobiliárias), agências de publicidade, escritórios de arquitetura e paisagismo, ajustaram-se e especializaram-se para

\footnotetext{
${ }^{62}$ A Cyrela criou as empresas de venda Seller e Selling para atuar nos segmentos de alta e baixa renda, respectivamente.

${ }^{63} \mathrm{~A}$ cada terreno comprado se associa uma receita esperada, isto é um VGV potencial. No mercado estima-se que o custo do terreno corresponda entre $5 \%$ e $20 \%$ do VGV do empreendimento (VEDROSSI, 2008, pag. 04), dependendo do segmento econômico. A viabilidade financeira que compõe o estudo de compra simula, com base nos dados do estudo de massa, as receitas, custos e despesas do negócio imobiliário que definem o VGV potencial do empreendimento, levando em consideração taxas de juros, velocidade de vendas, margem de lucro esperada, etc.. O potencial do terreno não é intrínseco ao terreno, mas uma leitura subjetiva da empresa que o avaliou, utilizada como parâmetro para precificar o terreno: "VGV de lanbank é medida, mas não é indicador de qualidade" (LIMA JR. 2008, pag. 1). A competição entre as incorporadoras favoreceu enormemente os donos dos terrenos e não raro levou a compras baseadas em premissas que não se confirmaram, "inflacionando determinadas contas das projeções de resultado, para alcançar os múltiplos desejados" (LIMA JR. 2008, pag. 1).
} 
atender os novos clientes. Na prática, para as incorporadoras que abriram o capital, a governança corporativa foi pré-requisito legal para que tivessem as ações comercializadas na Bolsa de Valores brasileira. A prestação de contas periódica e a cobrança de resultados por parte dos acionistas enfraqueceram a figura do dono de empresa empreendedor, que marcou a atuação do mercado imobiliário brasileiro na década de 1980 (LEITE, 2006). Ainda que permanecessem como “CEOs" de suas empresas, a exemplo de Cyrela, Rossi e Tecnisa, a tomada de decisão deveria ser balizada por dados financeiros, relatórios e análises de mercado, enfatizando o desenvolvimento dos empreendimentos sob a lógica do lucro.

\section{OS MEGAPROJETOS}

Capitalizadas e com demanda disponível, o grande desafio que se apresentou às incorporadoras foi de como aumentar as receitas rapidamente e assegurar os níveis de crescimento planejados. A solução dada a este dilema teve impacto decisivo na expressão forma-espacial na produção a partir da segunda metade da década de 2000: concentrar a operação em terrenos que apresentassem receitas potenciais maiores: "Evidencia-se a estratégia traçada por algumas empresas em empreender somente em áreas que permitam gerar grandes VGVs (Valor Geral de Vendas), podendo ser essa a premissa determinante para aquisição de áreas". (VEDROSSI et al., 2010). Estratégia esta observada tanto no segmento residencial, como no comercial.

Ao comparar a evolução do VGV médio por empreendimento na RMSP, verifica-se um crescimento real de $52 \%$ entre os intervalos analisados, atingindo R\$ 41 milhões por empreendimento
GRÁFICO 7: PARTICIPAÇÃO EMPREENDIMENTOS RESIDENCIAS VERTICAIS LANÇADOS NA RMSP, SEGUNDO VGV* (R\$ MILHÕES).

RMSP / 2001-2005

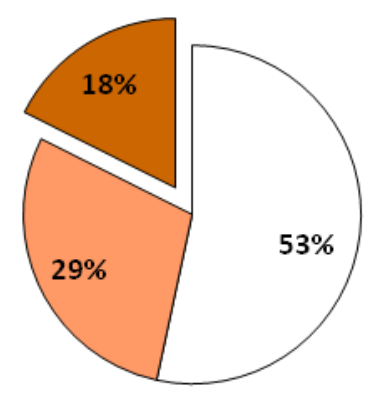

CONJUNTOS: 1.608

RMSP / 2006-2010

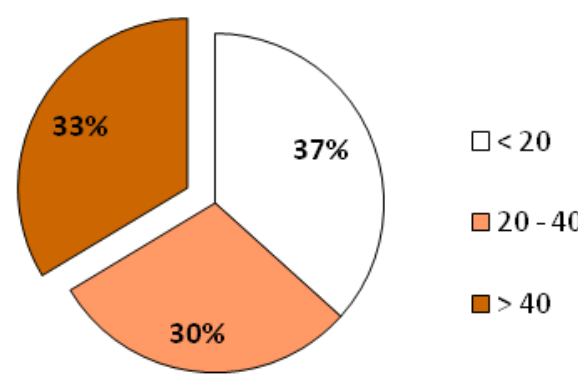

CONJUNTOS: 1.957

ELABORAÇÃO: Autor. FONTE: Base EMBRAESP * Valores constantes, base $03 / 2009$. Taxa de desconto: INCC. 
em 2006-2010. No intervalo 2001-2005, empreendimentos com VGV acima de R\$ 40 milhões correspondiam a 18\% e alcançaram 33\% no intervalo seguinte (GRÁFICO 8).

Nas décadas de 1970 e 1980 a realização de grandes VGVs encontrava dois empecilhos principais: o capital necessário e o risco envolvido. Primeiramente, a realização de um empreendimento exige a imobilização do capital próprio do incorporador necessário para a compra do terreno, para o lançamento do produto e para a construção do edifício, até que seja feito o repasse ao banco, e o dinheiro reintroduzido em caixa. Este investimento é diretamente proporcional ao porte do empreendimento, e corresponde de $25 \%$ e $30 \%$ do VGV, concentrados nos 12 primeiros meses (VEDROSSI, 2008, p.5) ou mais, dependendo da velocidade de vendas; uma disponibilidade financeira pouco comum em mercados restritos. Em segundo lugar, quanto maior o empreendimento, maior o risco de uma baixa aceitação por parte do público resultar em grandes estoques não vendidos. Caso isso ocorra, o incorporador, que imobilizou boa parte do capital de sua empresa em um único projeto, poderá abrir à falência.

Exemplo disto foi o empreendimento Ilhas do Sul (1973), de autoria de Albuquerque \& Takaoka. Totalizando 480 UHs em $28.473 \mathrm{~m}^{2}$ de área de lote, trazia, entre os conceitos inovadores, uma ampla área de lazer - entre as maiores até então - incluindo quatro piscinas, ginásio de esportes, restaurante, teatro, cinema, etc.. Apesar de ter se tornado uma referência, teve baixa aceitação do público e colocou a incorporadora em situação de risco: “O prazo total de 18 meses para vender as unidades não era usual (em geral se vendia em um mês), onerando a construtora com os juros do financiamento obtido para a execução da obra. [...] O aperto financeiro foi muito grande." (LEITE, 2006, p. 183) 
No contexto analisado, estes riscos não estavam mais presentes: as empresas estavam capitalizadas, a demanda era excedente e, por isso mesmo, o risco reduzido (a escassez de imóveis fez com que mesmo produtos não tão bem formatados fossem vendidos rapidamente, a exemplo dos empreendimentos realizados dentro do PMCMV).

Ao priorizar o desenvolvimento de VGVs maiores, as empresas se concentraram no desenvolvimento de um número relativamente reduzido de empreendimentos e alcançaram mais rapidamente as metas estabelecidas. A opção se justifica também, uma vez que, entre as etapas que constituem o ciclo de desenvolvimento do produto imobiliário, a negociação do terreno, caminho crítico $^{64}$ do processo, tem pouca variação de duração em relação ao porte financeiro do empreendimento ${ }^{65}$.

Os altos VGVs também permitiram ganhos de escala na estratégia de comercialização. Alguns artifícios já conhecidos foram aperfeiçoados, tornando-se praticamente indispensáveis para a atração do comprador: stand de vendas, apartamento decorado, maquete, imagens e campanhas, ganharam ares "hollywoodianos" e as premiações aos corretores que mais vendessem incluíram sorteios de viagens e carros. Com verbas de marketing e de vendas calculadas sobre porcentagens fixas do VGV, de $3 \%$ a $6 \%$, a utilização destes recursos não esteve condicionada ao padrão do empreendimento, viabilizando stands gigantescos e propagandas em rede de televisão aberta também para produtos econômicos.

Sob o ponto de vista da obra, empreendimentos com maior VGV no segmento econômico levaram à maior número de apartamentos e torres construídas, o que viabilizou o emprego de técnicas

${ }^{64}$ Caminho crítico: conjunto de etapas que condicionam a duração total mínima do projeto.

${ }^{65}$ Comprar um terreno de $2.000 \mathrm{~m}^{2}$ pode ser tão complexo como comprar um de $10.000 \mathrm{~m}^{2}$. 
industrializadas no canteiro. Em palestra ministrada na Faculdade de Arquitetura e Urbanismo (FAUUSP),

Ronaldo Cury, relações públicas da incorporadora e construtora Cury, especializada no padrão econômico, destacou que a realização de grandes empreendimentos viabilizou a introdução de novas tecnologias, a exemplo do uso de lajes e esquadrias de concreto fabricadas in loco, possibilitando redução do prazo de obras. Foi feito o uso intensivo de formas metálicas na construção de casas populares em concreto, seguindo os passos de mercados já aquecidos, como o mexicano. 


\section{CAPÍTULOS 03 - A CARACTERIZAÇÃO DO FENÔMENO}

Não por acaso o "boom" dos supercondomínios na metrópole paulistana coincide com o Boom imobiliário. Estes são expressão da reestruturação do processo produtivo, necessária à magnitude que o mercado habitacional alcançou no início do século XXI.

Para caracterizar o fenômeno, mas não encerrar a definição de supercondomínios declaradamente genérica - em quantidade mínima de UHs, torres, área do lote ou áreas de uso comum oferecidas, já que estes não são definitivos ${ }^{66}$, caracteriza-se o fenômeno, por meio de três tendências formais específicas que anunciam o aparecimento deste tipo de empreendimento: o aumento do tamanho do lote, o aumento do número de unidades por empreendimento e a ampla oferta de espaços de uso comum. Da mesma forma, o marco regulatório edilício será avaliado pela forma como contribuiu para reforçar estas tendências.

\footnotetext{
${ }^{66}$ No desenvolvimento deste trabalho propusemos limites quantitativos na tentativa de quantificar exatamente o número de supercondomínios e o seu crescimento: área mínima de lazer ofertada, mínimo de 200 apartamentos, mínimo de 3 torres, lote mínimo de $5.000 \mathrm{~m}^{2}$ e mesmo a combinação destes. No entanto, ficou claro que sempre haveria empreendimentos que fugiriam à regra (alguns $\mathrm{m}^{2}$ ou apartamentos a menos), fragilizando as conclusões realizadas. Neste sentido, percebemos que ao pesquisar as tendências formais que estão diretamente relacionadas com a expansão dos supercondomínios, cobriríamos um campo maior da discussão, pois tanto o capital imobiliário, como o marco regulatório edilício (e até a ideologia "da nova forma de morar") relacionam-se e definem tendências formais e não uma forma única e específica.
} 
Delimitou-se o campo de estudo, no espaço e tempo: empreendimentos imobiliários residenciais verticais $^{67}$ desenvolvidos por promotores imobiliários, na região da Região Metropolitana de São Paulo (RMSP), lançados ${ }^{68}$ entre 2001 e $2010^{69}$. A brevidade do período, apenas uma década, também ajuda a comprovar que os contrastes encontrados não são resultado de um processo de longo prazo, ou de mudanças culturais ou comportamentais de longa data, mas que expressam o novo mercado imobiliário que se delineou.

Ao comparar os dados entre os intervalos, considerou-se as novas dinâmicas territoriais que se delinearam durante o Boom para a leitura do fenômeno. A mudança no perímetro de atuação dos promotores imobiliários e a alteração dos municípios e distritos focos da atuação - tanto da capital em direção aos municípios vizinhos (GRÁfICo 08 - MAPAS 01/02/04), como dentro da capital, dos bairros

\footnotetext{
${ }^{67}$ Mínimo de 3 andares, com propriedade em condomínio. Optou-se por estabelecer um recorte na produção, subtraindo os condomínios horizontais, devido à dinâmica própria destes empreendimentos e à participação reduzida destes dentro da dinâmica imobiliária na RMSP: período de 2001-2010 os empreendimentos horizontais corresponderam a 7,9\% do total de unidades lançadas na RMSP.

${ }^{68}$ A data considerada é aquela do lançamento do empreendimento (início do período de comercialização) e não da conclusão da obra ou Habite-se ${ }^{68}$ - que tarda até três anos mais, uma vez que o imóvel é normalmente comercializado "na planta".

${ }^{69}$ Foram utilizadas duas fontes secundárias de dados: os dados coletados e organizados pela consultoria imobiliária Empresa Brasileira de Estudos de Patrimônio (EMBRAESP) e os dados de aprovação disponibilizados pela Secretaria de Habitação da PMSP. O período analisado foi dividido em dois intervalos de igual duração, 2001-2005 e 2006-2010, o primeiro representa a produção antes e o segundo durante o Boom imobiliário. Desde 1976, a EMBRAESP realiza uma pesquisa sistemática dos lançamentos imobiliários na RMSP São Paulo, acompanhando o mercado e as aprovações na prefeitura, aqui utilizada. Os dados apresentados, cruzando valores $x$ área $x$ localização já tabelados, são únicos. Atualmente, há um consenso no meio acadêmico que se dedica ao estudo do mercado imobiliário a respeito de sua confiabilidade, sendo amplamente referida em trabalhos recentes, conduzidos pelo Núcleo de Real Estate da Poli e pela Faculdade de Arquitetura e Urbanismo da USP, entre outras.
} 
tradicionais em direção àqueles de classe média - fizeram com que o fenômeno se apresentasse com diferentes intensidades nos diferentes territórios. Para isso, optou-se por observar a dinâmica metropolitana, comparando dois grupos geográficos: o Município de São Paulo (MSP) e os outros municípios que compões a região metropolitana (RMSP (-) MSP) e, em seguida, a dinâmica intramunicipal, no $\mathbf{M S P}^{70}$.

Para estabelecer uma possível relação entre os as tendências formais e o porte financeiro dos empreendimentos, o VGV dos empreendimentos foram considerados. Como o período analisado abrange 10 anos, os preços foram trazidos a valores constantes para a data de 03/2009 (quando o PMCMV foi lançado). A taxa de desconto utilizada foi o Índice Nacional da Construção Civil (INCC): referência amplamente utilizada para atualização dos contratos do mercado imobiliário, o índice mensal acompanha a variação dos custos de construção.

\footnotetext{
${ }^{70}$ A opção pela análise aprofundada apenas do MSP explica-se também pela limitação da base de dados utilizada.
} 


\section{1 - O AUMENTO DO PORTE FÍSICO DOS EMPREENDIMENTOS}

Como os promotores imobiliários buscaram maior eficiência operacional priorizando empreendimentos de maior VGV - tendo sido observado um aumento real de 52\% no VGV médio por empreendimento entre 2006-2010, em relação ao intervalo anterior - e a nova demanda qualificada se apresentou nos segmentos de padrão médio e econômico, o que se observou durante o Boom foi a realização de empreendimentos de maior porte, em número de unidades e área do lote.

A primeira informação que se destaca ao analisar a produção de empreendimentos residenciais verticais lançados na RMSP durante o Boom é a desconexão entre o aumento percentual do no de UHs e o no de empreendimentos lançados entre 2006-2010 (durante o Boom), em relação ao intervalo anterior (2001-2005, pré Boom) (QUADRO 05). Enquanto o primeiro cresceu 98\%, o segundo cresceu apenas $22 \%$. Com isso, a média de UHs por empreendimento variou 49\%, passando de 85 para 138 UHs.

O crescimento no número de UHs por empreendimento foi acompanhado pelo crescimento em $72 \%$ do porte do lote incorporado, passando de $3.051 \mathrm{~m}^{2}$ para $5.258 \mathrm{~m}^{2}$, evidenciando que o salto quantitativo observado no período do Boom deu-se por meio da adoção de uma nova tipologia de empreendimento residencial: os supercondomínios.

Confirmando a participação, ainda que indireta, do mercado financeiro no fenômeno, juntas, as sete maiores incorporadoras com ações negociadas na Bovespa em 2010, capitalizadas por meio da emissão de ações durante o período do Boom, tiveram área média de lote incorporado de $8.000 \mathrm{~m}^{2}$ no 
intervalo de 2006-2010, responderam por 35\% do total de unidades lançadas, $25 \%$ do total de empreendimentos lançados e por $45 \%$ dos empreendimentos lançados em lote superior a $10.000 \mathrm{~m}^{2}{ }^{71}$.

\section{QUADRO 5: EMPREENDIMENTOS RESIDENCIAIS VERTICAIS LANÇADOS NA RMSP}

\begin{tabular}{|c|c|c|c|c|c|c|c|c|c|}
\hline & \multicolumn{3}{|c|}{ MSP } & \multicolumn{2}{|c|}{ RMSP (-) MSP } & \multicolumn{4}{|c|}{ RMSP } \\
\hline INTERVALO & $2001-2005$ (A) & $2006-2010$ (B) & B/A\% & 2001-2005 (A) & $2006-2010$ (B) & B/A\% & 2001-2005 (A) & $2006-2010$ (B) & B/A\% \\
\hline UNIDADES & 107.855 & 167.724 & $56 \%$ & 28.492 & 101.807 & $257 \%$ & 136.347 & 269.531 & $98 \%$ \\
\hline EMPREENDIMENTOS. & 1.292 & 1.346 & $4 \%$ & 316 & 611 & $93 \%$ & 1.608 & 1.957 & $22 \%$ \\
\hline$\Sigma$ LOTES $\left(\mathrm{m}^{2}\right)$ & 3.764 .278 & 6.300 .129 & $67 \%$ & 1.142 .085 & 3.990 .249 & $249 \%$ & 4.906 .363 & 10.290 .377 & $110 \%$ \\
\hline UNID./ EMPREND. & 83 & 125 & $49 \%$ & 90 & 167 & $85 \%$ & 85 & 138 & $62 \%$ \\
\hline ÁREA LOT/ EMP. $\left(\mathrm{m}^{2}\right)$ & 2.914 & 4.681 & $61 \%$ & 3.614 & 6.531 & $81 \%$ & 3.051 & 5.258 & $72 \%$ \\
\hline
\end{tabular}

ELABORAÇÃO: Autor. FONTE: Base EMBRAESP

O fenômeno se manifestou de forma mais acentuada na RMSP(-)MSP, onde a média do lote incorporado passou de $3.614 \mathrm{~m}^{2}$ para $6.531 \mathrm{~m}^{2}$, e o número de UHs por empreendimento de 90 para 137. A maior intensidade coincidiu com uma maior participação destes na dinâmica imobiliária da RMSP (GRÁFICO 9).

\footnotetext{
${ }^{71}$ Para este cálculo, foram considerados também aqueles empreendimentos realizados por meio de parcerias com outras incorporadoras.
} 
Entre 2001-2005, RMSP(-)MSP respondeu por 21\% das UHs lançadas na RMSP e, no intervalo seguinte, por $40 \%$. Durante o boom imobiliário o número de UHs lançadas na capital cresceu cerca de $60 \%$, enquanto que na RMSP(-)MSP o crescimento foi de cerca de $260 \%$, dados que confirmam o processo de descentralização da atividade imobiliária na metrópole paulistana na segunda metade da década. O grande volume se concentrou em municípios vizinhos À capital (MAPAS 01/02/04). Entre 2006 e 2010, cinco dos 39 municípios que compõem a região - Santo André, São Bernardo do Campo, São Caetano, Guarulhos e Barueri - responderam por 68\% das UHs lançadas na RMSP( $\neg$ )MSP e por 25\% das UHs lançadas na RMSP.

Com empreendimentos com número de UHs e tamanho de lote médios significativamente maiores que os lançados no MSP, os dados revelam que, além da mudança de "foco" do mercado para os municípios vizinhos da capital que compõe a RMSP, esta foi feita à custa de empreendimentos de maior porte físico (MAPAS 02/03), que garantiam sua atratividade mercadológica ao oferecer aos promotores imobiliários volumes financeiros cada vez mais próximos àqueles alcançados por empreendimentos realizados na capital. O MAPA 04 mostra que, ainda que a capital continue concentrando os maiores empreendimentos residências verticais em porte financeiro (VGV), entre 2006-2010, a região do $A B C$, Guarulhos e Barueri apresentaram um grande salto em relação ao porte financeiro dos empreendimentos lançados. Enquanto o VGV médio por empreendimento teve um crescimento de 47\% no MSP, na RMSP(JMSP alcançou 134\% (GRÁFICO 10).
GRÁFICO 8: PARTICIPAÇÃO (\%) UHs EM EMPREENDIMENTOS RESIDENCIAIS VERTICAIS LANÇADOS NA RMSP.

\section{UU1-2UUS}

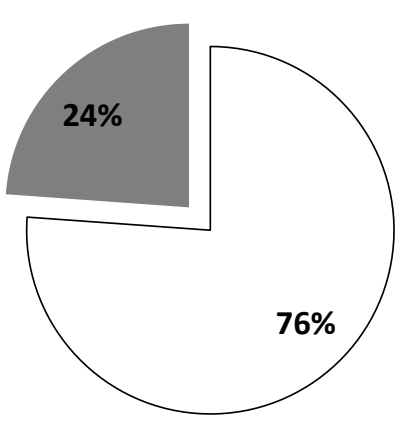

2006-2010

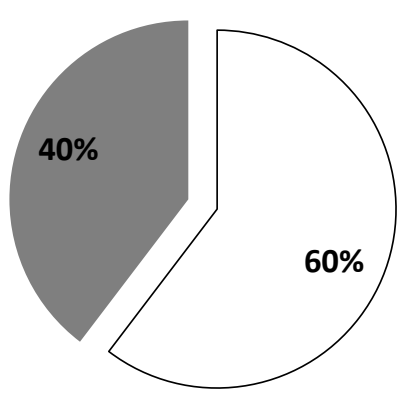

$\square$ MSP RMSP - MSP 
GRÁFICO 9: EMPREENDIMENTOS RESIDENCIAIS VERTICAIS LANÇADOS NA RMSP - EVOLUÇÃO VGV* MÉDIO POR EMPREENDIMENTO (R\$̦ MILHÕES)

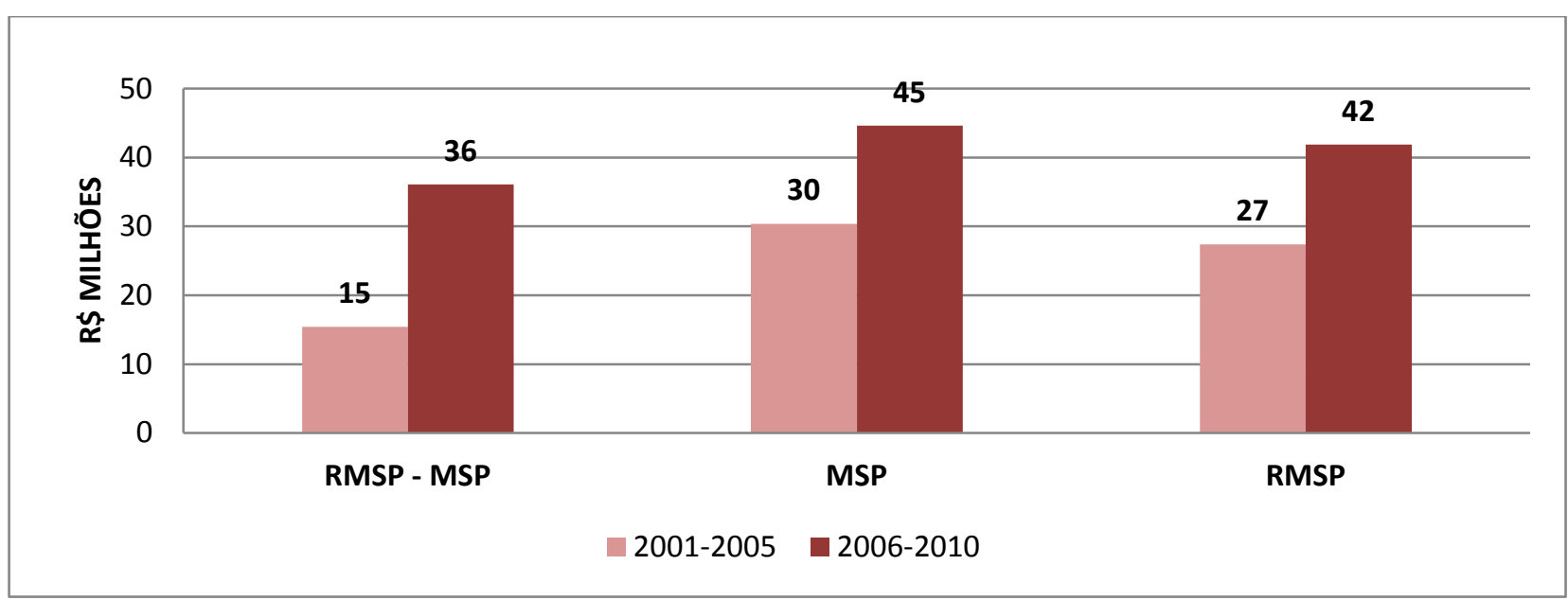

ELABORAÇ̃̃: Autor. FONTE: Base EMBRAESP

* Valores constantes, base 03/2009. Taxa de desconto: INCC.

Em UHs, o município de Guarulhos manteve-se como o segundo maior mercado da região metropolitana, atrás apenas da capital. Entre 2001-2005, respondeu por 4\% da RMSP e por 18\% da RMSP (-) MSP e, no intervalo seguinte, 2006-2010, por $8 \%$ e $20 \%$, respectivamente. O porte médio do lote incorporado passou de $5.032 \mathrm{~m}^{2}$ para $8.494 \mathrm{~m}^{2}$, sendo um dos principais mercados dos supercondomínios e, em área total incorporada, o município passou de aproximadamente $195.000 \mathrm{~m}^{2}$ para $740.000 \mathrm{~m}^{2}, \mathrm{um}$ crescimento de $280 \%$. 
No entanto, em área média de lote, Cotia $\left(19.024 \mathrm{~m}^{2}\right)$, Carapicuíba $\left(15.697 \mathrm{~m}^{2}\right)$, Suzano $\left(12.618 m^{2}\right)$, Mogi das Cruzes $\left(9.339 m^{2}\right)$ e Barueri $\left(9.234 m^{2}\right)$ superaram Guarulhos, o que se explica-se pela abundancia de terrenos vagos e, no caso de Cotia, pelo processo de urbanização dispersa que caracterizou a sua ocupação. Em sentido, contrário, contribuindo para a redução desta média na RMSP(IMSP tem-se São Bernardo do Campo $\left(4.697 \mathrm{~m}^{2}\right)$, Santo André $\left(3.794 \mathrm{~m}^{2}\right)$ e São Caetano do Sul $\left(2.446 \mathrm{~m}^{2}\right)$, municípios densamente ocupados, com terrenos grande escassos na mancha urbana principal.

A exemplo de Diadema, que teve um crescimento de $900 \%$ no total de UHs lançadas ( $262 \rightarrow 3.099$ UHs), outros municípios, ainda que com pouca expressão, apresentaram grandes saltos em relação ao intervalo anterior, caso de Santana de Parnaíba $(0 \rightarrow 2.195$ UHs), Cotia $(320 \rightarrow 3.327$ UHs), Cajamar $(480 \rightarrow 2.894$ UHs) e Taboão da Serra ( $539 \rightarrow 3.453$ UHs), mostrando um novo foco de atuação do mercado imobiliário. O crescimento observado nestes municípios foi impulsionado pelas disponibilidade de lotes livres, em área dotada de infraestrutura, marcada pela urbanização dispersa. Barueri (1.935 $\rightarrow 9.546$ UHs), mostrou um processo de intensa verticalização e, assim com Santana do Parnaíba e Cotia, se estabeleceu como destino da classe média.

Entre as justificativas para essa investida dos promotores imobiliários nos municípios vizinhos, destaca-se o custo menor do terreno em comparação com o MSP, viabilizando a criação de empreendimentos nos moldes dos lançados na capital, mas com preços reduzidos. Fato reforçado uma vez que o grande mercado que se apresentou durante o Boom, foi o dos segmentos de padrão médio e econômico, característico destes municípios. Entretanto, o crescimento de mercado observado na RMSP(-)MSP, sugere (já que não há dados disponíveis para quantificar este movimento) que a demanda 
não se restringiu aos mercados locais: ao oferecer também menores custos de vida e facilidade de acesso, estas localidades foram "marketizadas" pelos promotores imobiliários como alternativa economicamente viável, ainda que como cidade dormitório, ao restrito mercado habitacional da capital.

A ampliação do raio de atuação do mercado imobiliário foi também

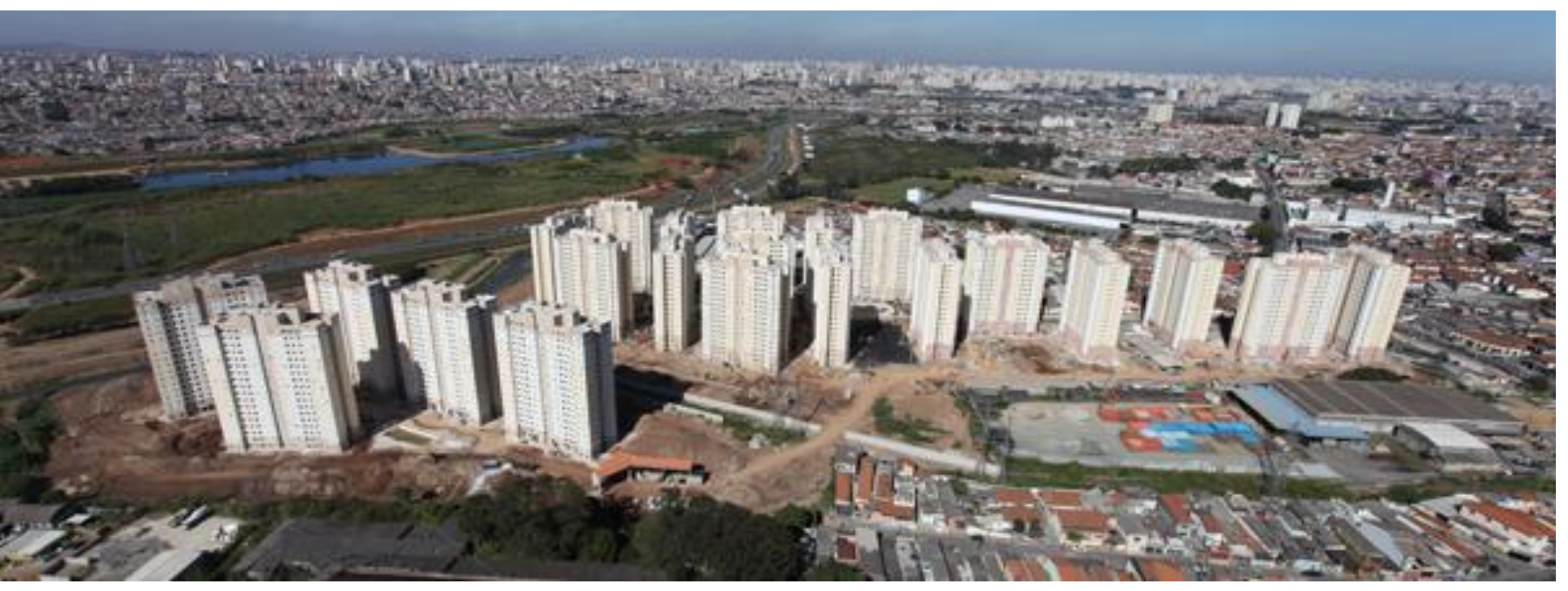

O município de Guarulhos recebeu dois impulsionada pelo programa habitacional do Governo Federal, Programa Minha Casa Minha Vida (PMCMV-mar/09). Em busca de terrenos "baratos" que viabilizassem o desenvolvimento de unidades adequadas ao programa, as incorporadoras paulistas rumaram para bairros da zona leste e municípios vizinhos (onde os limites de preço final máximo estabelecidos pelo PMCMV mantiveram-se iguais aos da capital). Entre 2009 e 2010 foram lançados 192 empreendimentos, num total de cerca de 44.000 unidades, com as características necessárias para integrar o programa ${ }^{72}$. A RMSP(-)MSP respondeu por cerca de $57 \%$ das unidades.

dos maiores lançamentos do PMCMV na RMSP, o Único e o Máximo (a frente) Incorporadora Cury/Living:

Único

Terreno de $72.094 \mathrm{~m}^{2}$ № de torres: 17

№ de andares: 17 pavimentos Número de unidades por andar: 8 Total de unidades: 2.380 Máximo Terreno de $26.025 \mathrm{~m}^{2}$ № de torres: 5 № de elevadores por torre: 2

${ }^{72}$ Para esta análise considerou-se apenas o enquadramento da unidade de menor preço do empreendimento no valor teto estabelecido pelo programa (R\$ 130.000,00 na RMSP), definido para a modalidade FGTS (renda de 3 a 10 salários mínimos). Este número diz respeito apenas àqueles empreendimentos lançados por incorporadoras no período de 2009 e 2010 e que, podem 
Ao aprofundar a análise do aumento da área média do lote incorporado na RMSP, (GRÁFICO 11), observa-se que o aumento do porte do lote incorporado não corresponde a um processo contínuo. Iniciou-se em 2006 e acentuou-se em 2007, quando responderam por 38\% das UHS lançadas na RMSP, e manteve-se neste novo patamar nos anos seguintes. A mudança brusca durante o Boom reforça a tese de que a alteração tipológica está diretamente ligada à alteração do contexto sócio econômico, e enfraquece o senso comum de que este seria apenas um modismo motivado pela mudança do gosto do público.

GRÁFICO 10: EMPREENDIMENTOS RESIDENCIAIS VERTICAIS LANÇADOS NA RMSP - PARTICIPAÇÃO POR PORTE DO LOTE INCORPORADO $\left(\mathrm{m}^{2}\right)$

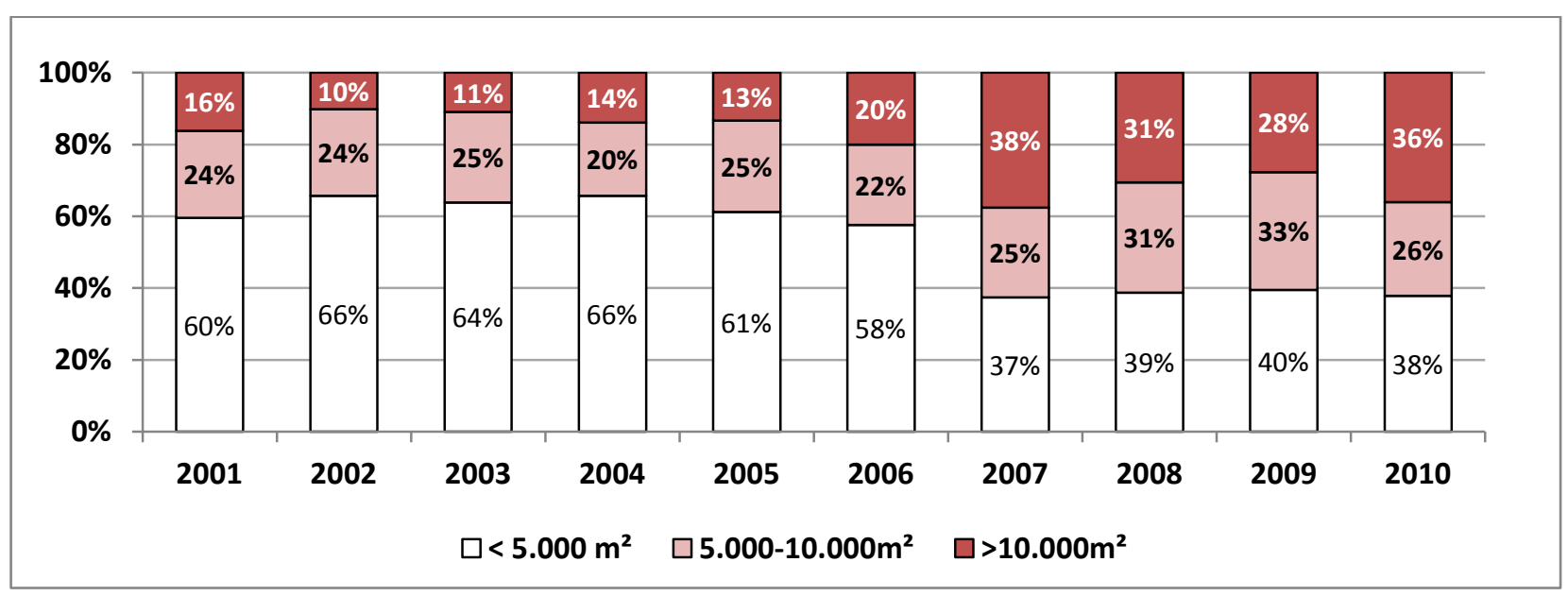

ELABORAÇÃO: Autor. FONTE: Base EMBRAESP

ter sido motivados pelo advento do programa. O programa também admite a participação de unidades que tenham sido lançadas anteriormente, desde que satisfizessem as exigências legais, aumentando significativamente. 
Dando seqüência a este enfoque, O GRÁfICO 12 evidencia que, em número de empreendimentos, aqueles com área de acima de $10.000 \mathrm{~m}^{2}$, apresentam uma pequena participação percentual de mercado. Contudo, respondem por uma parcela significativa das UHS lançadas e da área em lote incorporada. $\mathrm{Na}$ RMSP, no intervalo de $2001-2005$, $4 \%$ dos empreendimentos responderam por $13 \%$ das UHs lançadas. Percentual que subiu para $13 \%$ e $32 \%$, respectivamente, no intervalo seguinte. De forma simplificada, o dado mostra que $32 \%$ das famílias que adquiram um imóvel neste segundo período irão morar em empreendimentos com área de lote acima de um quarteirão "padrão" $\left(100 \mathrm{~m} \times 100 \mathrm{~m}=10.000 \mathrm{~m}^{2}\right)$. Em valores absolutos, isto é, considerando o crescimento do mercado, o número de UHs em empreendimentos acima de $10.000 \mathrm{~m}^{2}$ passou de 17.509 para 85.376 - um crescimento real de cerca de $400 \%$. Como será observado adiante, o porte do lote será um fator determinante para o surgimento dos supercondomínios. Ainda que não tenha sido definida uma área mínima para que isto ocorra, fica claro que para lotes com área acima de $10.000 \mathrm{~m}^{2}$, este modelo será, na prática, imperioso.

Mais uma vez esta mudança foi acentuada na RMSP (-) MSP. Entre 2001-2005, apenas 5\% dos empreendimentos lançados ocupavam lote superior a $10.000 \mathrm{~m}^{2}$, percentual que subiu para $20 \%$ no intervalo seguinte, passando a responder por $44 \%$ das UHs lançadas e, em valores absolutos, aproximadamente $45.000 \mathrm{UHs}$. Mesmo respondendo por apenas $40 \%$ do total de UHs lançados na RMSP, entre 2006-2010, a RMSP(-)MSP recebeu mais de 50\% das UHs em empreendimentos com área acima de $10.000 \mathrm{~m}^{2}$. 
GRÁFICO 11: EMPREENDIMENTOS RESIDENCIAIS VERTICAIS LANÇADOS NA RMSP - PARTICIPAÇÃO POR PORTE DO LOTE INCORPORADO $\left(\mathrm{m}^{2}\right)$, RMSP, NO MSP E NA RMSP(-)MSP

\section{RMSP}

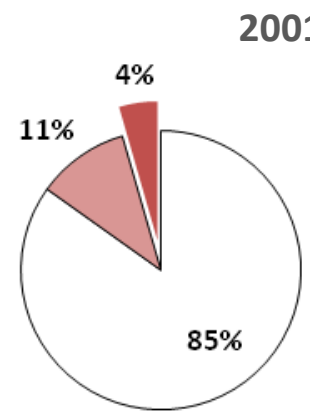

EMPREEND.: 1.608

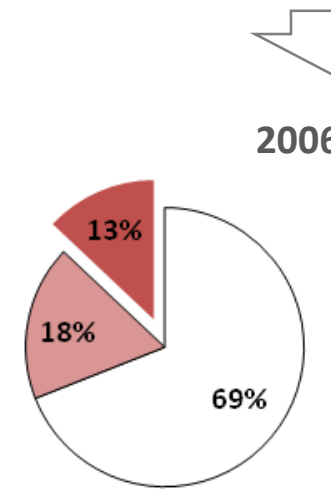

EMPREEND.: 1.957

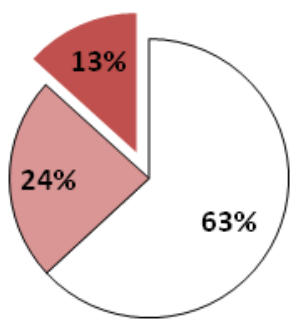

UHs: 136.347

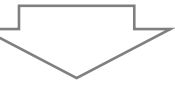

2006-2010

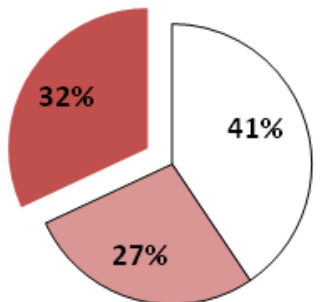

UHs: 269.531
MSP

2001-2005

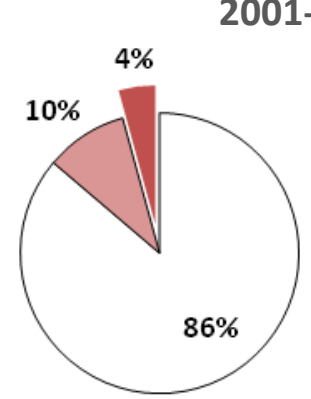

EMPREEND.: 1289

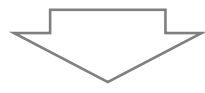

2006-2010

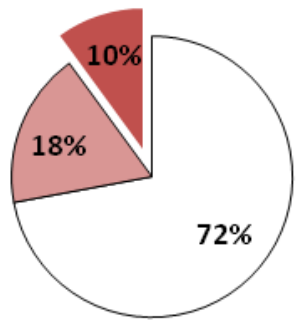

EMPREEND.: 1.321

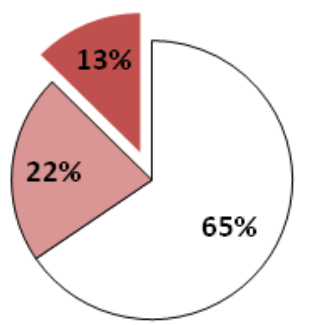

UHs: 107.535

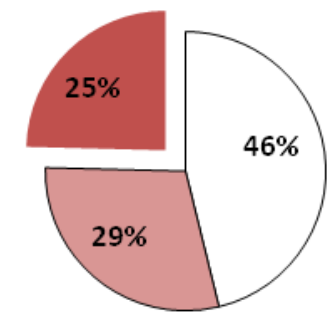

UHs: 162.621
RMSP (-) MSP

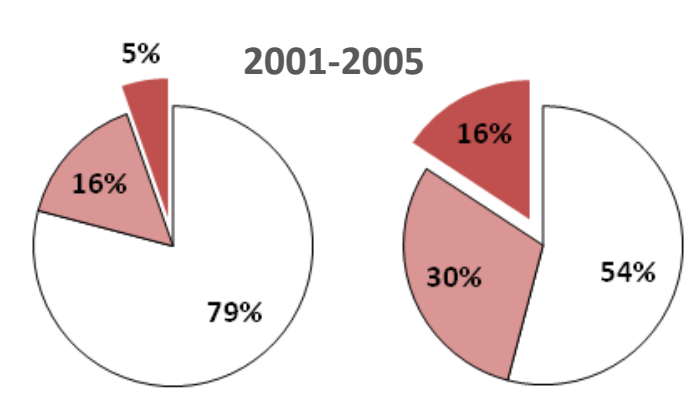

EMPREEND.: 319

UHs: $\mathbf{2 8 . 8 1 2}$

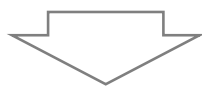

2006-2010

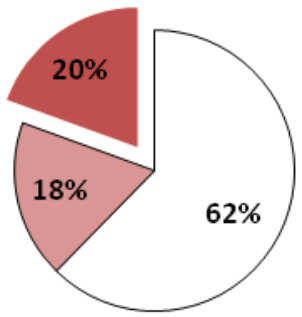

EMPREEND.: 636

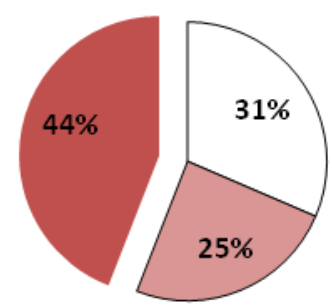

UHs: 106.860 
O fenômeno dos supercondomínios também pode ser notado pela evolução do ranking anual dos maiores empreendimentos residenciais verticais, por tamanho do lote, lançados na RMSP. (QUADRO 6). Após 2005, mesmo excluindo o ano atípico de 2007 (pré-crise), os maiores empreendimentos em área de lote alcançaram portes significativamente maiores que aqueles no início da década. Desde então, o Green Tamboré (2006), em Barueri foi o maior produto lançado, com $79.100 \mathrm{~m}^{2}$, seguido pelo Anima Clube Parque Condomínio (2007), em São Bernardo do Campo, com $67.200 m^{2}$ e pelo Domínio Marajoara (2006), no bairro de Interlagos, São Paulo, com $66.000 \mathrm{~m}^{2}$.

QUADRO 6: EMPREENDIMENTOS RESIDENCIAIS VERTICAIS LANÇADOS NA RMSP - RANKING POR PORTE DE LOTE INCORPORADO ( $\left.\mathrm{m}^{2}\right)$

\begin{tabular}{|c|c|c|c|c|c|c|c|c|c|c|c|}
\hline ANO & 10 & 20 & 3o & 40 & 5o & 6o & 70 & 80 & 9o & 10 - & TOTAL \\
\hline 2001 & 51.000 & 26.500 & 19.200 & 18.300 & 18.000 & 13.900 & 13.600 & 12.900 & 12.500 & 11.900 & 197.800 \\
\hline 2002 & 20.300 & 19.100 & 18.600 & 15.600 & 15.600 & 15.600 & 15.400 & 15.000 & 13.500 & 12.600 & 161.200 \\
\hline 2003 & 23.300 & 18.700 & 17.500 & 16.900 & 15.600 & 15.600 & 14.700 & 13.600 & 13.100 & 11.600 & 160.500 \\
\hline 2004 & 23.300 & 18.700 & 17.500 & 16.900 & 20.000 & 18.800 & 16.500 & 15.000 & 11.600 & 11.400 & 169.700 \\
\hline 2005 & 63.800 & 47.400 & 36.400 & 21.500 & 18.000 & 17.600 & 15.600 & 15.500 & 14.000 & 13.700 & 263.500 \\
\hline 2006 & 79.100 & 51.400 & 43.800 & 36.000 & 29.700 & 20.000 & 19.200 & 17.700 & 17.000 & 16.700 & 330.700 \\
\hline 2007 & 67.200 & 66.000 & 57.200 & 52.200 & 47.900 & 47.200 & 45.500 & 43.500 & 43.300 & 40.400 & 510.400 \\
\hline 2008 & 58.100 & 48.600 & 37.100 & 34.900 & 33.600 & 30.900 & 29.500 & 28.900 & 28.700 & 27.600 & 357.900 \\
\hline 2009 & 59.400 & 50.700 & 35.800 & 33.900 & 33.900 & 32.600 & 27.300 & 26.700 & 18.700 & 16.700 & 335.700 \\
\hline 2010 & 49.700 & 39.500 & 29.400 & 26.000 & 25.000 & 25.000 & 24.200 & 24.100 & 24.000 & 23.900 & 290.900 \\
\hline
\end{tabular}




\section{A DINÂMICA INTRAMUNICIPAL}

Na capital, o fato de que o número de empreendimentos lançados entre 2006-2010 cresceu apenas $4 \%$ em relação ao intervalo anterior, enquanto que o número de UHs por empreendimento cresceu 47\% (QUADRO 5) - confirma que o Boom não se expressou pelo volume de empreendimentos lançados, mas pelo volume de unidades lançadas, ou, por conseqüência, pelo aumento do porte físico dos empreendimentos.

No MSP, a difusão dos supercondomínios durante o Boom, coincide com a mudança de eixo de atuação dos promotores imobiliários, do centro para a "periferia", descrevendo fluxo semelhante ao observado entre a capital e os municípios vizinhos da RMSP, (MAPAS 05/06/07). Destacaram-se três dinâmicas espaciais principais: (i) a redução da participação, em UHs e VGV dos tradicionais bairros de elite no mercado paulistano; (ii) a mudança de foco para os bairros tradicionais de classe média, com a intensificação naqueles de passado industrial e de armazenamento; (iii) a expansão do perímetro de atuação, agregando a área de atuação bairros na periferia antes ignorados.

Historicamente, os distritos que concentraram a atividade imobiliário no MSP eram aqueles onde vivia a elite, explicado pela própria dedicação do mercado ao segmento de alta. Ainda que este perímetro varie conforme a época avaliada, este tem se concentrado no eixo sudoeste da cidade, antes da travessia do rio Pinheiros. Para facilitar uma comparação quantitativa, definimos o seguinte grupo, Alto de Pinheiros, Perdizes, Consolação, Pinheiros, Jardim Paulista, Vila Mariana, Moema, Itaim Bibi, Liberdade e Saúde. 
Entre 2001-2005, este conjunto de 10 distritos recebeu 30.559 UHs e, entre 2006-2010, 19.322 UHs, uma queda de aproximadamente $36 \%$. No mesmo intervalo o no de UHs lançadas no MSP cresceu $51 \%$, o que fez com que a participação deste grupo no total de UHs lançadas na capital fosse reduzida de $28 \%$ para $12 \%$. Ainda que isoladamente alguns destes tenham apresentado crescimento positivo, todos tiveram desempenho abaixo da média do mercado (MAPAS 11 E 12).

A redução da atividade nestes é explicada pela escassez de lotes com as características necessárias - fato agravado pela competição de que os poucos lotes disponíveis sofrem para o uso comercial, que geralmente permite a prática de preços de terreno maiores que como local de moradia privilegiado - e não pela diminuição do prestígio destes que, ao contrário, conservaram os maiores valores por $\mathrm{m}^{2}$ de área privativa. Em média, estes distritos tiveram uma redução de $20 \%$ no acumulado de área incorporada (MAPAS 13 E 14).

Mesmo tendo recebido apenas $12 \%$ das UHs lançadas, estes respondem por cerca $24 \%$ do VGV lançado na capital, pouco, em relação aos $44 \%$ no intervalo anterior, mas muito, em relação ao porte financeiro do mercado imobiliário paulistano. Considerando o VGV lançado por distrito, o eixo sudoeste continuou sendo o foco financeiro da atividade imobiliária. O que se viu é que, enquanto antes os distritos de Jardim Paulista, Vila Mariana Moema, Itaim Bibi e Vila Andrade (este último, pela disponibilidade avantajada de lotes vagos) receberam os maiores investimentos, este perímetro se expandiu para a Zona Sul, englobando Campo Belo, Santo Amaro e Campo Grande (MAPAS 15 E 16). 
A redução da participação dos distritos de elite não significou uma crise do mercado imobiliário de alto padrão, mas, mais uma vez uma expansão deste segmento no território. No recente período analisado, novos distritos adquiriam o mesmo status. Esta constatação é confirmada quando se verifica quais bairros receberam os apartamentos mais caros. Dividiram espaço com os distritos tradicionais de elite o Morumbi, a exemplo do empreendimento Parque Cidade Jardim (2006 - apartamentos a partir de R\$ 6 milhões) e do The Park (2004 - apartamentos a partir de R\$ 4 milhões); o Tatuapé, a exemplo do empreendimento Gaus Anália Franco (2008 - apartamentos a partir de R\$ 1,2 milhões) e do Mont Blanc (2008 - apartamentos a partir de R\$ 1,2 milhões) e Lapa (2008 - apartamentos a partir de R\$ $627.000,00)$.

Pela dificuldade em se encontrar lotes de grandes proporções nestes distritos, ou formá-los, por meio de remembramento, a média do lote incorporado deste grupo está bastante abaixo da média da capital de $4.500 \mathrm{~m}^{2}$. Entre 2001-2005, 1.950m² e, entre 2006-2010, 2.100m². Assim como nos MAPAS 06 e 07, onde a espacialização dos maiores empreendimentos em porte físico descreve um anel ao redor da deste conjunto de distrito, o fato demonstra que a ocorrência dos supercondomínios nos tradicionais distritos de elite é pouco significativa. Foram a segunda e a terceira dinâmicas que expressaram o fenômeno dos supercondomínios no MSP.

Se a carência de lotes vagos nos distritos tradicionais os tornou inacessíveis ao comprador de classe média, estes definiram os centros dos novos vetores de atuação do mercado: do Itaim Bibi para o Campo Belo, Santo Amaro e Campo Grande; do Alto de Pinheiros e Perdizes para à Barra Funda (MAPA 11 e 12). Acentua-se, em total de UHs lançadas, a participação dos distritos Centro/Zona Leste: Tatuapé, 
Carrão, Vila Formosa, Água Rasa, Mooca, Belém e Vila Maria; e, daqueles vizinhos à Vila Mariana e à Saúde: Cursino e Sacomã.

Mas foi o eixo ao longo do rio Pinheiros que concentrou os supercondomínios (MAPAS 6 E 7). Observaram-se dois perfis de distritos: aqueles que apresentavam disponibilidades de lotes vagos ainda não ocupados: exemplo de Vila Sônia, Vila Andrade e Morumbi; e aqueles de passado industrial e de galpões: Vila Leopoldina $\left(9.200 \mathrm{~m}^{2}\right)$, Jaguaré $\left(6.300 \mathrm{~m}^{2}\right)$ e Santo Amaro $\left(5.100 \mathrm{~m}^{2}\right)$ e Campo Grande $\left(16.400 \mathrm{~m}^{2}\right)$.

No segundo grupo, destaca-se o caso do distrito da Vila Leopoldina. Desde o início da década de 2000, o local passou a ser foco dos lançamentos imobiliários. Com um passado de galpões industriais, a disponibilidade de grandes lotes, em área bem localizada, vizinha do Bairro City Lapa, e de fácil acesso às áreas centrais. O distrito apresentou as características ideais para a realização de grandes empreendimentos e, por conseqüência, grandes VGVs. Ao total entre 2001-2010, foram lançados 43 empreendimentos no distrito da Vila Leopoldina. Destes, 19 entre 2006-2010, dos quais seis ocuparam lote maior que $10.000 \mathrm{~m}^{2}$, totalizando $110.000 \mathrm{~m}^{2}$.

Cabe lembrar que a maior participação da RMSP(-)MSP na dinâmica imobiliária na RMSP também se explica pela disponibilidade de grandes lotes industriais e de galpões subutilizados que os municípios vizinhos da capital apresentavam. Grupo que, no MSP, também abrange Barra Funda $\left(5.400 \mathrm{~m}^{2}\right)$ e Mooca $\left(4.600 \mathrm{~m}^{2}\right)$, na Zona Central. 
Por fim, a expansão do perímetro de atuação, agregando à área de atuação bairros na periferia antes não explorados, foi impulsionada pela disponibilidade de lotes vagos. Por se concentrarem do segmento de padrão médio e, principalmente, econômico, os maiores lotes se explicariam, mais uma vez, pela necessidade de desenvolver negócios imobiliários de porte financeiro que acompanhasse àqueles lançados nos distritos centrais. Exemplo destes são os distritos de Cangaiba $\left(8.700 \mathrm{~m}^{2}\right)$, São Lucas $\left(8.300 \mathrm{~m}^{2}\right)$, São Mateus $\left(8.100 \mathrm{~m}^{2}\right)$ e Itaim Paulista $\left(7.200 \mathrm{~m}^{2}\right)$, na Zona Leste; Jaraguá $\left(13.000 \mathrm{~m}^{2}\right)$ e Cachoeirinha $\left(5.500 \mathrm{~m}^{2}\right)$, na Zona Norte; Raposo Tavares $\left(15.000 \mathrm{~m}^{2}\right)$; e Morumbi $\left(7.000 \mathrm{~m}^{2}\right)$, Vila Sônia $\left(7.500 \mathrm{~m}^{2}\right)$ na Zona Oeste e, Vila Andrade $\left(5.700 \mathrm{~m}^{2}\right)$ e Campo Limpo $\left(11.000 \mathrm{~m}^{2}\right)$ na Zona Sul, sendo esta zona mais representativa, em quantidade de UHs lançadas. 


\section{2 - A AMPLA OFERTA DOS ESPAÇOS EM CONDOMÍNIO}

Praça de entrada principal, praça contemplativa, praça de apoio ao espaço gourmet, praça de apoio ao salão de festas juvenil, praça central de acesso aos blocos, praças de convivência sob pergolados, redário sob pergolado de madeira, praça das palmeiras, estares sob pergolados, praça das mamães, praça dos tabuleiros sob pergolado, praça dos aromas, praça teen, praça mirante sob deck de madeira, praça de leitura, piscina infantil, playground para crianças de 7 a 12 anos, piscina recreativa, piscina recreativa adulto com raia de $25 \mathrm{~m}$, piscina de biribol, spa com hidromassagem, deck de madeira, solarium, prainha (deck molhado), playground infantil para crianças de 0 a 6 anos, trilha de cooper e caminhada, estações de minigolf, quadra oficial de tênis, quadra gramada, equipamentos de ginástica, churrasqueira (com espaço para mesas, forno de pizza e lavabo), pomar, jardins, bichos de madeira, orquidário, salão de festas adulto com copa e lavabos, espaço gourmet com lavabos, salão de festas infantil com copa e lavabos, salão de festas juvenil com copa e lavabos, sala de jogos adultos, fitness, espaço cultural, sports lounge, piscina climatizada e coberta com raia de $15 \mathrm{~m}$, sala de massagem, quadra coberta, "brinquedotecas" 0 a 4 anos e 5 a 7 anos, atelier infantil, salão de jogos juvenil, games, espaço hobby, spa e sauna com ducha e sala de descanso, atelier de artes - adulto, cinema com foyer e lounge cafeteria com lavabos. Itens de lazer do Podium Vila Leopoldina (2008), Vila Leopoldina, São Paulo - Incorporadora Cyrela.

A terceira tendência que caracteriza os supercondomínios e os diferencia dos ditos empreendimentos residenciais verticais "convencionais" seria a ampla oferta de espaços de lazer livres e cobertos, oferecidos em condomínio, compondo uma suposta "nova forma de morar". Velhos conhecidos no mercado habitacional, a inovação deu-se pela atualização do programa destes espaços e pela maior abrangência do mercado consumidores, em especial da classe média.
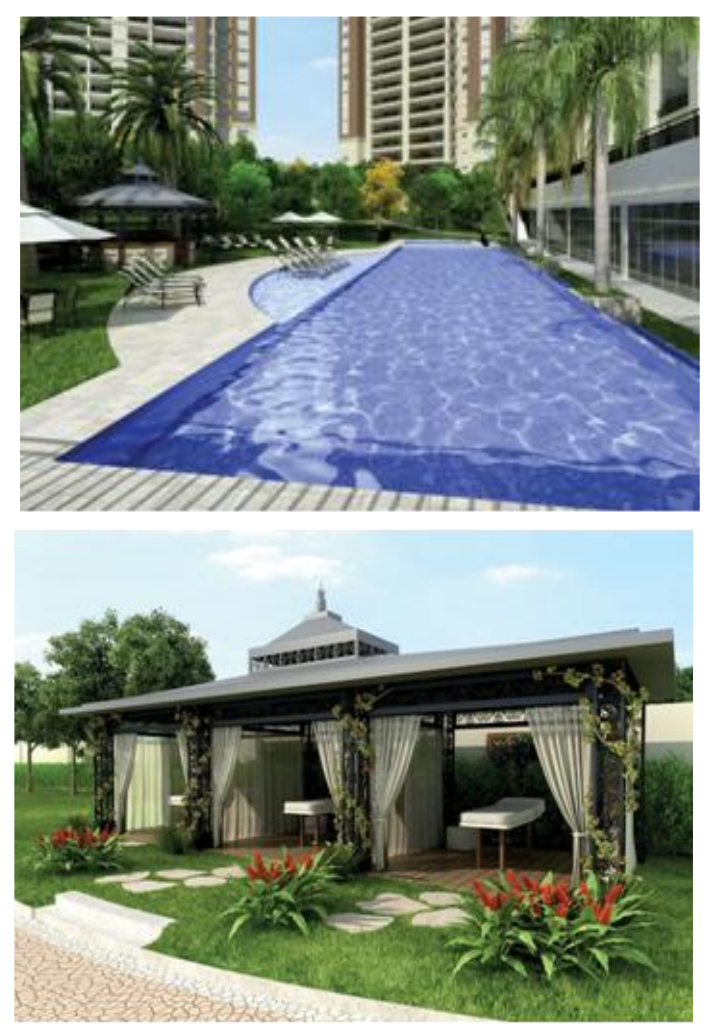

Referência áreas externas em condomínio no segmento de padrão médio e alto 
Em primeiro lugar, por oferecer um espaço livre privado de uso comum, generoso, seguro, acolhedor e revigorante, em contraposição ao espaço público, precário, inseguro, opressor e estressante, percepção comum aos moradores de áreas urbanas brasileiras.

Em segundo lugar, com a atual tendência à produção de apartamentos de pequenas dimensões na RMSP, com a redução da área construída sem a redução do programa a ser abrangido, as áreas de uso comum ganharam também status de extensão do espaço privado (GAVIÃO, 2012 e ARAGÃO,2005). Este partido projetual é observado nos novos itens de lazer que vem sendo oferecidos. Enquanto alguns espaços são projetados para promover o convívio social entre os moradores, a exemplo de piscinas, quadras, jardins e praças, outros são de uso agendado, para que o morador receba seus amigos: a inviabilidade de se receber os amigos para o jantar em casa, devido à área restrita do apartamento, é superada pelo advento do salão gourmet. Na mesma categoria encontram-se a pequena oficina, o escritório, o bangalô de massagem e a lavanderia.

Entretanto, as avaliações pós-ocupação (APOs) realizadas em condomínios indicam que estas áreas são subutilizadas pelos seus moradores, colocando em dúvida os argumentos de vendas fundamentados nos benefícios materiais. Em Muito além do pavimento térreo. As áreas de lazer no mercado imobiliário em São Paulo, Gavião (2012) faz uma análise tipológica dos espaços em condomínios dos empreendimentos residenciais verticais. Por meio de entrevistas em profundidade, a autora realizou uma pesquisa de satisfação junto aos moradores de alguns edifícios. Apesar da amostragem limitada (inclusive, focada apenas no segmento de classe média) a autora fez interessantes constatações.

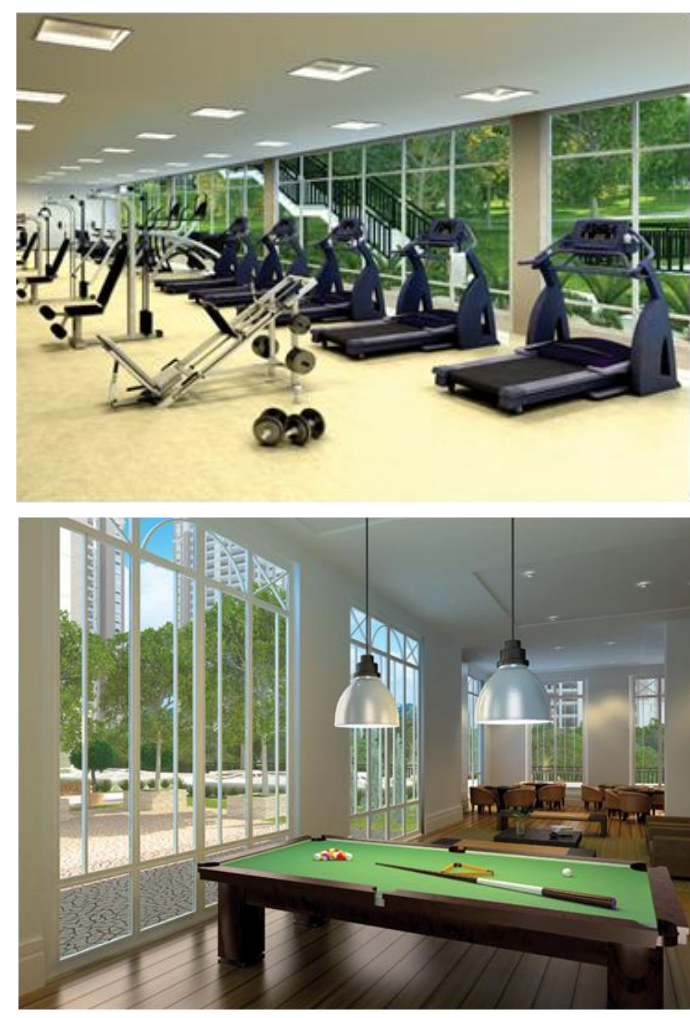

Referência áreas internas em condomínio no segmento de padrão médio e alto 
Os moradores quase não freqüentam as áreas em condomínio e os equipamentos são usufruídos principalmente pelas famílias com crianças, que tem o tempo livre necessário. Ainda assim, o uso intenso é restrito apenas aos itens mais convencionais, como playground e piscina.

Também foi constatado que o custo de manutenção destes espaços subutilizados, onerando o condomínio, tem, inclusive, levado à sua supressão. Com base nos estudos realizados pelo Eng. Marcio Kawashima, do Núcleo de Real Estate da Poli, em fevereiro de 2009, o jornal a Folha de São Paulo estampou a matéria “Condomínios cortam 'diferenciais' de lazer"73, onde apresentava o fracasso de equipamentos de lazer que incorriam em grandes custos para serem mantidos, como piscinas aquecidas, ou que causavam problema de gestão, como lan house e home theather para adolescentes. Espaços e equipamentos que foram "marketizados" no momento da compra, mas que se mostraram um estorvo no dia-a-dia.

O fato das avaliações consultadas indicarem que, do ponto de vista prático, estes espaços não são plenamente usados e, por isso, levariam a custos de manutenção desnecessários, não nega a validade do conforto psicológico que estes conferem. Conforme verificado por Gavião "[os moradores] gostam de saber que contam com piscina, churrasqueiras e outras áreas de lazer à disposição, mesmo que não as usem." (2012, p. 48)
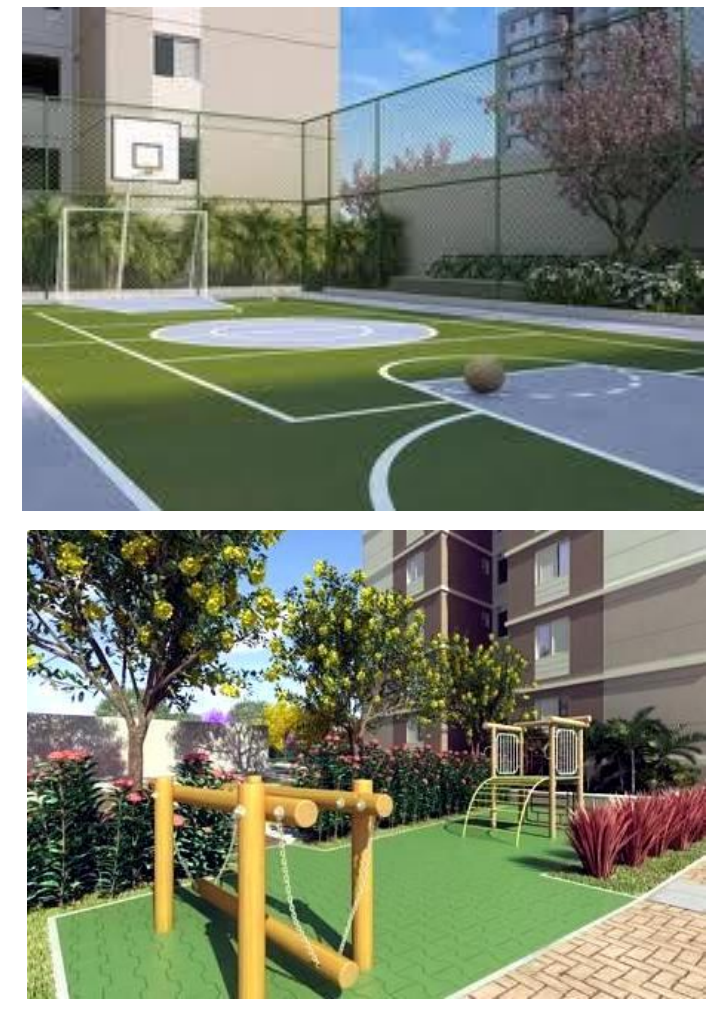

Referência áreas externas em condomínio no segmento de padrão econômico

${ }^{73}$ Folha Cotidiano. Condomínios cortam "diferenciais" de lazer - Vinícius Queiroz Galvão. Fevereiro de 2009. 
Significaria dizer que, independente do uso ou não, pelo seu valor simbólico, a disponibilidade e propriedade destes espaços e equipamentos oferece um conforto imaterial, o atendimento das necessidades sociais e de autorrealização.

Em terceiro lugar, está a capacidade de tornar tangível o produto empreendimento (intangível) e auxiliar a concretização da venda. Uma função que passa despercebida do comprador, mas é muito valorizada pelo promotor imobiliário.

Segundo estudo sobre o comportamento do consumidor realizados em marketing (KOTLER, 2000) (JACOB \& KAPLAN, 1972), o processo de compra de bens duráveis, a exemplo da casa própria, é denominado de alto envolvimento. Como são compras que ocorrem esporadicamente, que tem um alto custo e que exigem um comprometimento por longo prazo, envolvem alto risco - funcional, financeiro, físico, social e psicológico - caso a compra não se comprove acertada. O que faz com que a efetivação da compra tarde para ocorrer e seja permeada de insegurança.

Tipicamente, o alto risco percebido nas compras de bens duráveis, e compensado, pelo vendedor, com a disponibilização do máximo de informações possíveis do produto em questão, além de garantias e assistência técnica. Contraditoriamente, o modelo conduzido pelos promotores imobiliários no Brasil está fundamentado na chamada venda na planta, quando o imóvel é comercializado antes que ele seja construído. O que o comprador adquire é um compromisso de que, no futuro, ele receberá o apartamento desejado, trazendo ainda mais insegurança ao comprador. A frase "Não vendemos casas, vendemos sonhos" adquire um sentido muito mais pragmático. 
Mas como a venda do imóvel na planta oferece grandes vantagens ao promotor imobiliário, entre elas, a menor exposição de caixa (como apresentado), é preciso que este crie formas alternativas para tornar o projeto compreensível para o público leigo e transmitir a seriedade da operação. Stands de vendas suntuosos, apartamentos modelo-decorado, maquetes e, principalmente, as perspectivas ilustradas são ferramentas correntes utilizadas para preencher este vazio.

Neste contexto, a 'maquiagem' das áreas em condomínio ganha importância e oferece maior liberdade a arquitetos e paisagistas. Com os custos de construção ditando cada vez mais a forma da unidade habitacional e das torres, os espaços livres, pelas características de cada terreno, e as áreas em condomínio, são utilizados para conferir identidade e agregar valor ao empreendimento.

Mas o arquiteto está longe de ser aquele que define o projeto a ser realizado. Nas palavras de Forty (2007), fazer uma análise do "design", descontextualizada, sugere que "os designers, desempenham o papel principal na produção, uma concepção errônea, que corta efetivamente a maioria das conexões entre design e os processos da sociedade." (2007, p.13). Os projetos desenvolvidos são orientados segundo a sua adequação comercial: de um lado, equipes de engenharia realizando o controle de custos, do outro, os autodenominados especialistas no comportamento do consumidor, consultorias, empresas de marketing e empresas de comercialização - e, por vezes, o escritório de arquitetura - a fim de garantir que as inovações propostas estejam alinhadas com os gostos já identificados daquele público alvo a que se dirige o empreendimento. Submetidos ao briefing das empresas de vendas, agências de publicidades e consultorias, volta e meia, o projeto de arquitetura e paisagismo passa a ter como objetivo principal, a criação de subsídios para a montagem do material de promoção. A supervalorização da 
imagem, sendo os espaços livres o principal tema explorado, chega ao ponto de inverter a lógica do projeto paisagístico, onde o projeto submete-se à imagem, ao invés da imagem submeter-se ao projeto. $\mathrm{E}$ o atendimento das necessidades de uso e manutenção destes espaços pelos futuros moradores fica em segundo plano. As áreas externas poderão compor um grande jardim contemplativo com vegetação nativa, ao gosto modernista, ou pequenos jardins conectados de uso ativo com vegetação exótica, de estilo neoclássico, e nas áreas internas, um grande e avantajado salão de festas, ou uma coleção de pequenos espaços "contemporâneos" como salão mulher, salão gourmet e lounge.

Apesar disto, na prática, a avaliação qualitativa indicou que a "ampla" oferta de espaços de uso comum uma questão relativa. Se a avaliação mostra que durante o Boom o porte físico dos empreendimentos aumentou consideravelmente, o mesmo parece não ter ocorrido, em termos proporcionais, em relação à oferta de espaços livres por UH. O dado que sugere esta interpretação é a evolução da área do lote por apartamento, isto é, o resultado da divisão da área do lote, pelo total de UHs. Enquanto que, na década analisada, a área do lote aumento consideravelmente após 2006, a área de lote por apartamento sofreu um leve aumento até 2007, e se reduziu nos anos seguintes, descrevendo movimentos sem relação aparente. 
GRÁFICO 12: EMPREENDIMENTOS RESIDENCIAIS VERTICAIS LANÇADOS NA RMSP - COMPARATIVO EVOLUÇÃO ÁREA DO LOTE MÉDIO INCORPORADO X UHS.

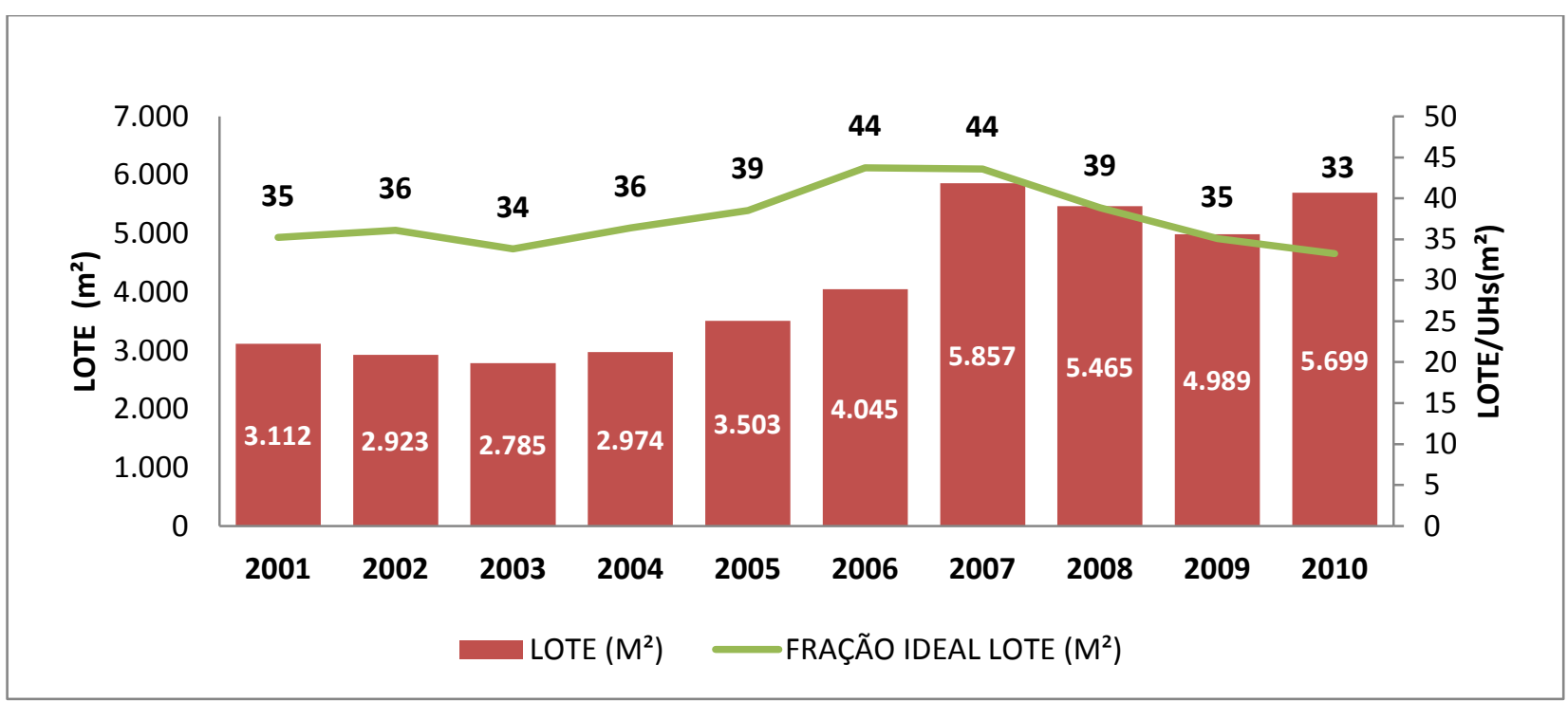

ELABORAÇÃO: Autor. FONTE: Base EMBRAESP

Ao avaliar os projetos, observou-se que, o que explica a variedade de espaços deuso comum são as potencialidades projetuais advindas do aumento do porte do lote, entre elas, o ganho de eficiência dos espaços livres e a ausência de critérios de dimensionamento.

No primeiro caso, ao definir a implantação de lotes maiores, as torres de apartamentos podem ser dispostas de forma que favoreçam o aproveitamento dos espaços livres. A exemplo da ILUSTRAÇÃO 1, ao aglutinar os espaços livres existentes e reduzir os espaços livres residuais, aumentam-se as possibilidades para compor o programa de espaços livres. Por exemplo, eliminando corredores de 
circulação estreitos e áreas sombreadas junto aos muros que não possuem a dimensão mínima necessária para instalação de um equipamento. O uso das áreas verdes também é potencializado. Quando contiguas, as áreas verdes viabilizam a formação de maciços e a opção por espécies arbóreas de maior porte, oferecendo o espaço necessário para o desenvolvimento das copas.

ILUSTRAÇÃO 1: AUMENTO DO LOTE X GANHO DE EFICIÊNCIA NO USO DOS ESPAÇOS LIVRES
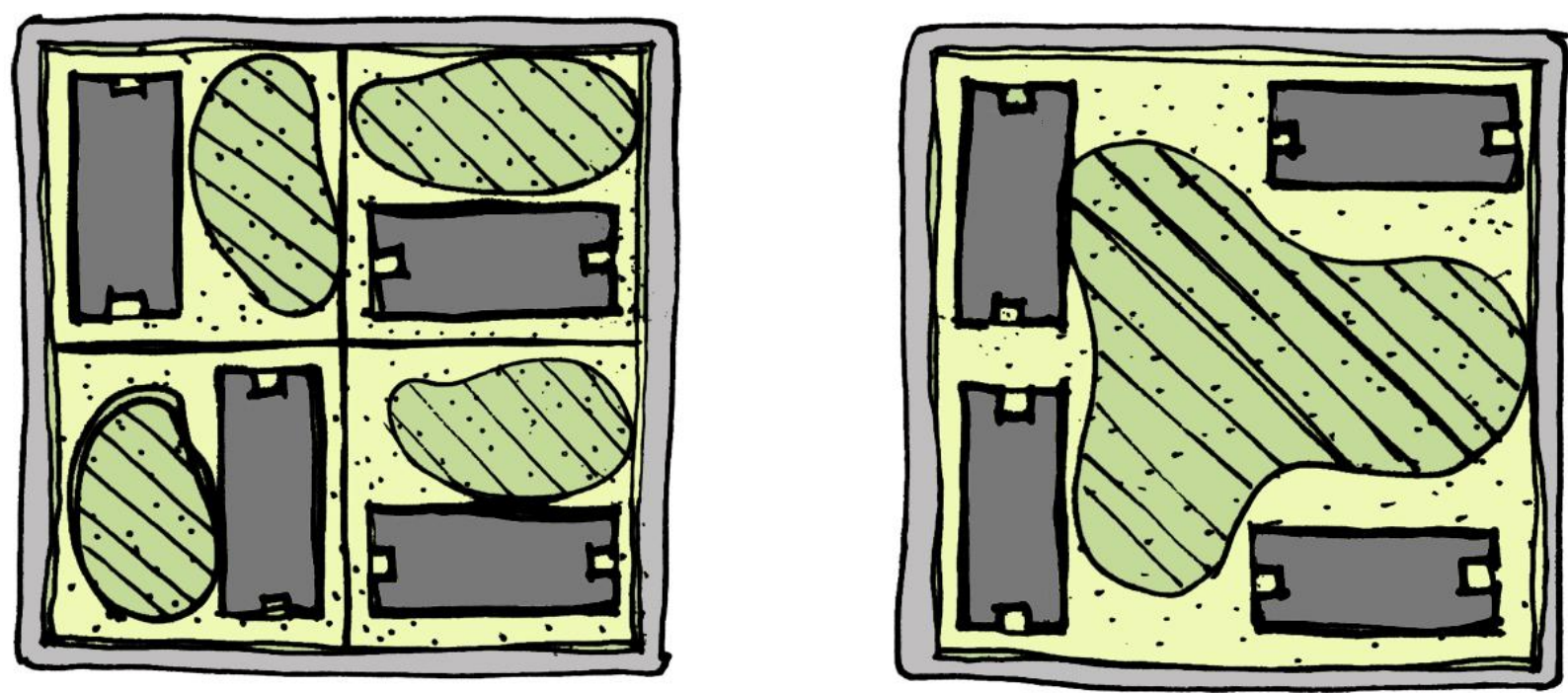

ELABORAÇÃO: Autor.

Da mesma forma, em lotes de menor porte, o programa de espaços e equipamentos de lazer oferecidos tende a ser reduzido pela indisponibilidade de área; via de regra restringindo-se ao básico: piscina, playground, churrasqueira e salão de festas, independentemente do número de futuros moradores. O programa se torna ainda mais restrito pois existe uma dimensão ou quantidade mínima 
que cada espaço ou equipamento deverá ocupar. Desta forma, a medida que o lote aumenta, aumenta a eficiência do projeto, equilibrando a demanda e a oferta dos espaços condominiais, evitando o superdimensionamento.

No segundo caso, a ausência de critério leva a falta de proporcionalidade entre a quantidade dos itens de lazer oferecidos e o total de futuros usuários. Uma vez que as imagens dos espaços livres são importantes ferramentas para a comercialização dos empreendimentos, e que nestas, o apelo emocional se sobrepõe ao funcional (usual em qualquer propaganda), os espaços e equipamentos propostos parecem ser os mínimos necessários para compor os ângulos das perspectivas ilustradas, numa equação em que quanto mais imagens e maior o número de itens de lazer, melhor. Como o uso e a manutenção destes espaços e equipamentos será feitos pelos futuros moradores, estes critérios se tornam secundários.

Esta situação é mais grave nos empreendimentos de padrão econômico, onde se supõe que os equipamentos de uso comum serão mais utilizados face ao acesso limitado à infraestruturas similares fora do condomínio. Tomando por exemplo o empreendimento popular Máximo (2010), em Guarulhos, com 700 apartamentos. As churrasqueiras são oferecidas em três unidades. Considerando que as famílias conseguem utilizar as churrasqueiras, efetivamente, nos fins de semana, cada churrasqueira poderá ser usada 100 vezes ao ano. Como a relação de churrasqueiras é de uma para cada 230 famílias, cada família terá o direito de usá-las a cada dois anos, caso todas as famílias assim o desejem (o mesmo ocorre com o único salão de festas infantil existente, a área da piscina, etc..). 
A ausência de critérios de dimensionamento dos espaços livres em condomínio na legislação foi destacada por Aragão (2005, p.73):"Para o cálculo dos espaços livres necessários à aeração e insolação dos compartimentos internos [o Código de obras de 1992], introduziu uma nova fórmula, sem excluir as determinações da Lei de Parcelamento, Uso e Ocupação do solo de 1972. Mas em nenhuma de suas seções ou artigos, prescreveu normas referentes à insolação e ventilação dos próprios espaços livres."

ILUSTRAÇÃO 2: POTENCIALIDADES DO AUMENTO DO LOTE
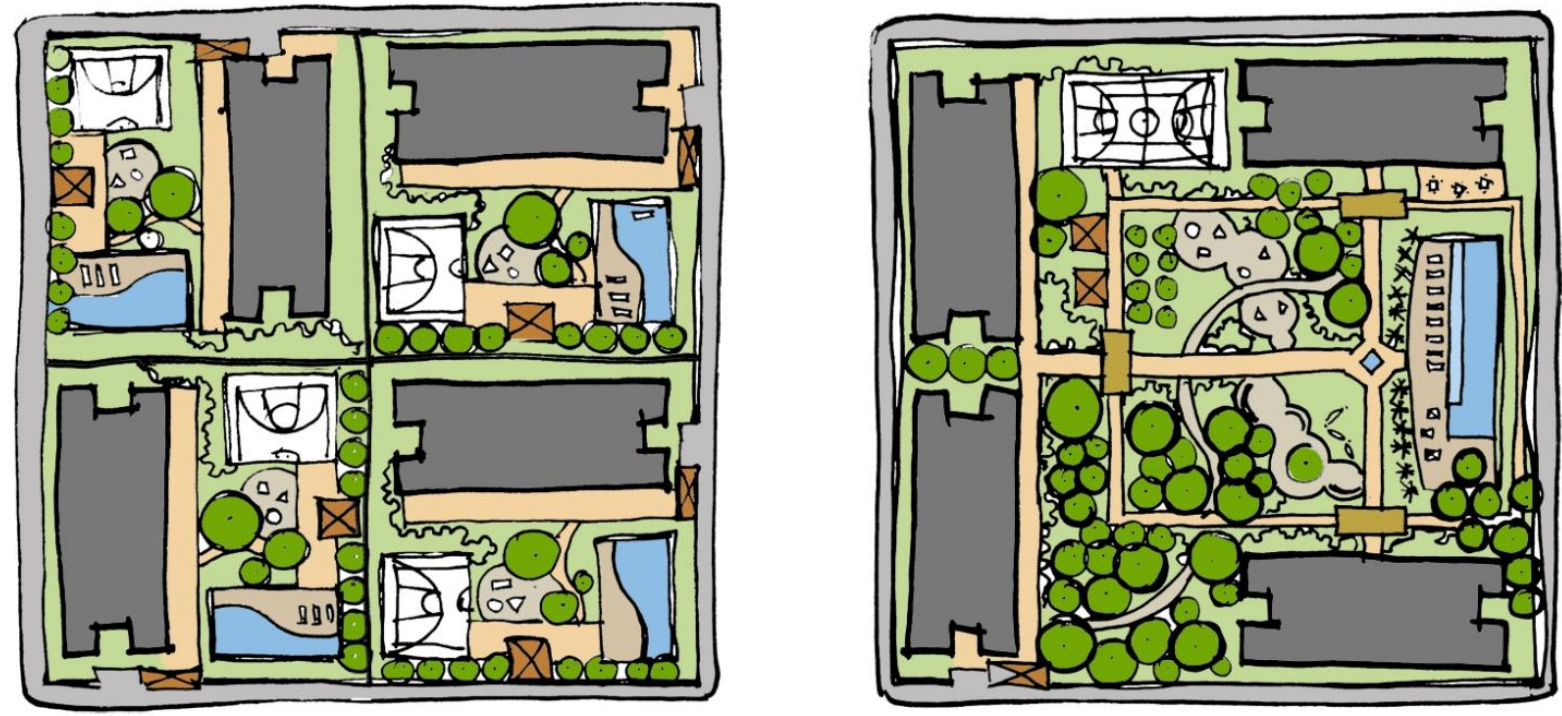

ELABORAÇÃO: Autor.

A ILUSTRAÇão 2 esclarece como o ganho de eficiência e ausência de critérios de dimensionamento, somados, contribuem para explicar a "ampla" oferta de espaços livres. Ambas as imagens apresentam a mesma dimensão e quantidade de torres e, por decorrência, o número de apartamentos. Na primeira 
imagem, a cada torre corresponde um empreendimento e um condomínio. Devendo atender um programa mínimo, todas dispõem de uma pequena piscina, um pequeno playground e uma meia quadra.

As árvores são de pequeno porte, para que não impeçam o uso destes espaços, ou sombreiem os lotes vizinhos.

$\mathrm{Na}$ segunda imagem, as quatro torres compõem um único empreendimento, um único condomínio. A redistribuição das torres em "U”, a gosto do mercado, levou à formação de uma grande praça central, o que viabilizou a proposição de um pequeno bosque, caminhos variados com pérgulas, praças e playground variados. Conta também com uma quadra oficial. Um caminho central que chega a uma fonte e, atrás, uma piscina com raia de $25 \mathrm{~m}$, prainha, guarda-sóis e espreguiçadeiras, é emoldurada por fileira de palmeiras.

Comparando as duas imagens, observa-se que, a área de superfície de piscina dos quatro empreendimentos juntos é maior que a área de superfície da piscina do empreendimento da segunda imagem. Juntos, os quatro empreendimentos totalizam quatro quiosques com churrasqueira, contra dois na segunda imagem e, as quatro meias quadras, que correspondem a duas completas, na primeira imagem, deram lugar a apenas uma quadra completa na segunda imagem.

Entretanto, a simplicidade dos espaços ofertados na primeira imagem indica que se trata de quatro condomínios residenciais verticais "convencionais", e a "ampla" oferta de espaços em condomínio da segunda imagem indica que se trata de um único supercondomínio, a exemplo daqueles que se multiplicaram durante o Boom. 


\section{3 - A CARTOGRAFIA DO FENÔMENO}

Para a melhor avaliar o fenômeno dos supercondomínios, foram realizados mapas temáticos, destacando as tendências que expressaram o aumento dos supercondomínios durante o Boom Imobiliário. Os empreendimentos residências verticais lançados foram destacados segundo três características: total de UHs por empreendimento, porte do lote e VGV, revelando no território a concentração daqueles de maior porte, físico e financeiro.

Os mapas se dividem em três grupos:

Os MAPAS 01, 02, 03 e 04, abrangem a RMSP.

Os MAPAS 05, 06, 07 e 08, focam no MSP. Nestes foi destacado, além dos empreendimentos, as médias de UHs por empreendimento, porte do lote e VGV, por distrito.

Os MAPAS $09,10,11,12,13,14,15$, e 16 , apresentam os resultados acumulados por distrito, apresentando as novas estratégias de atuação dos promotores imobiliários no território. 


\section{1-2005}

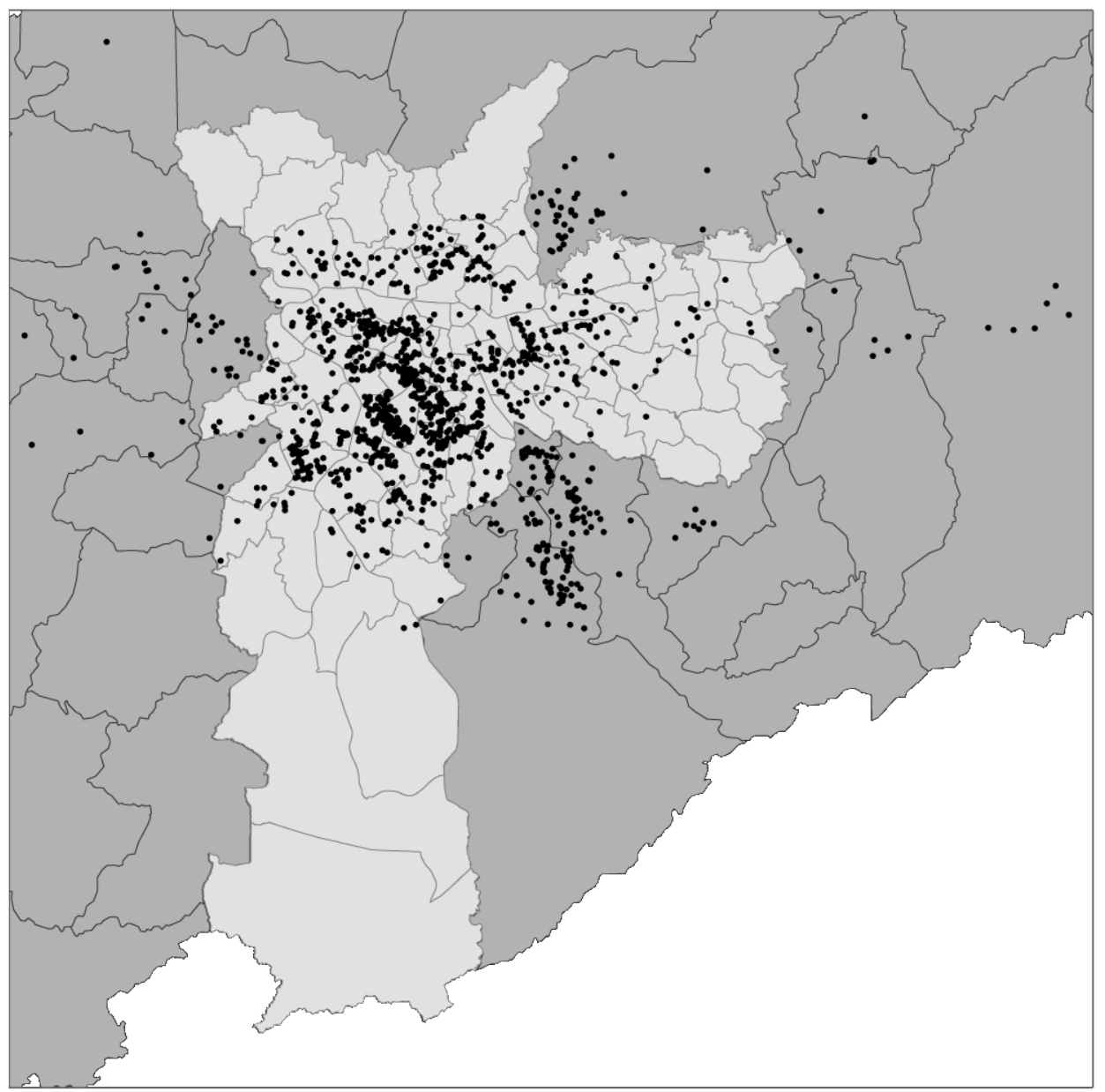

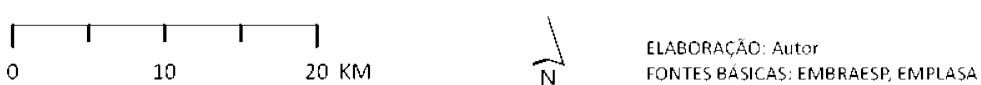

$2006-2010$

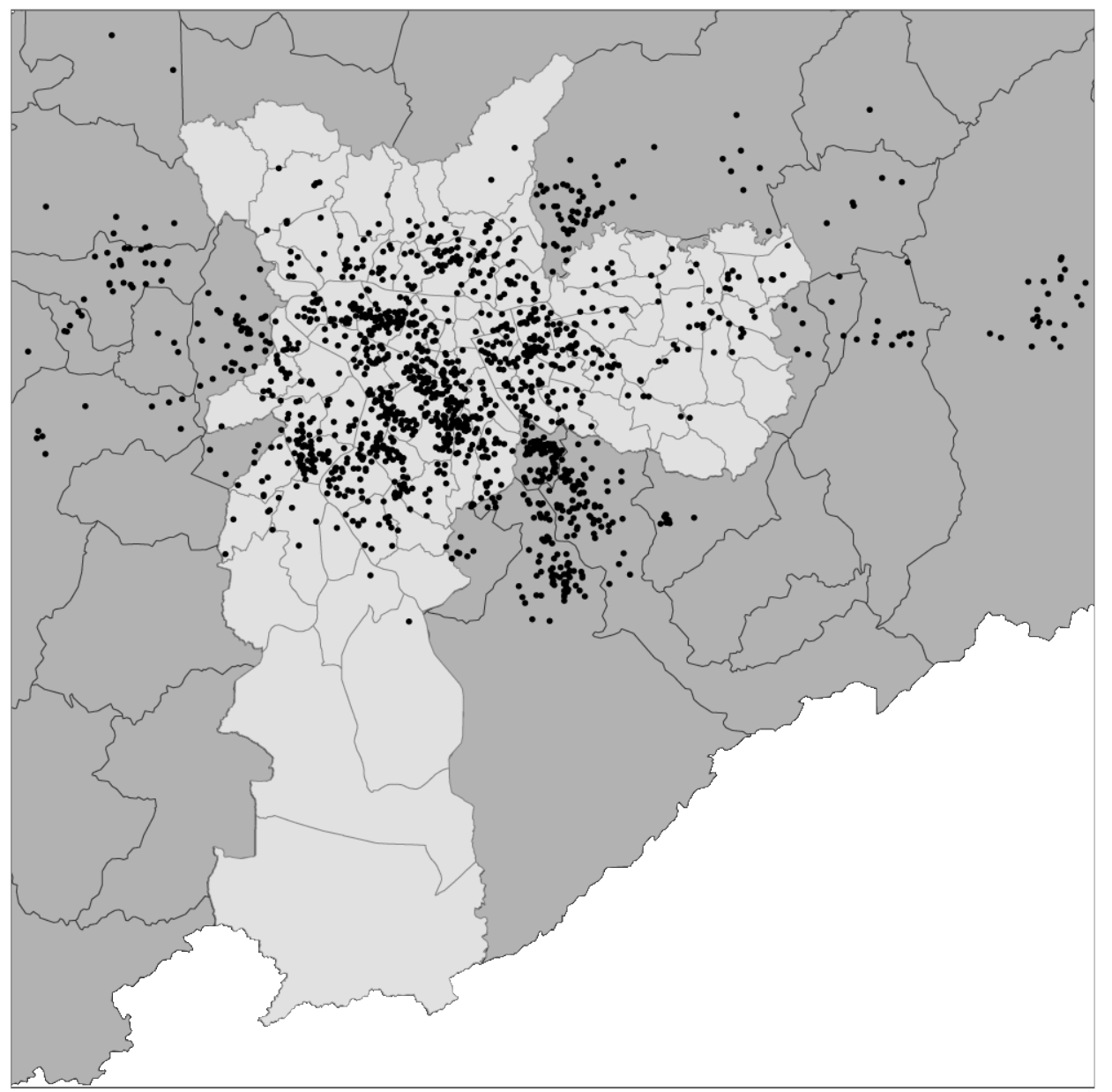

UHS/ EMPREENDIMENTO

- 1

MSP_Distritos

RMSP_Municípios 


\section{1-2005}

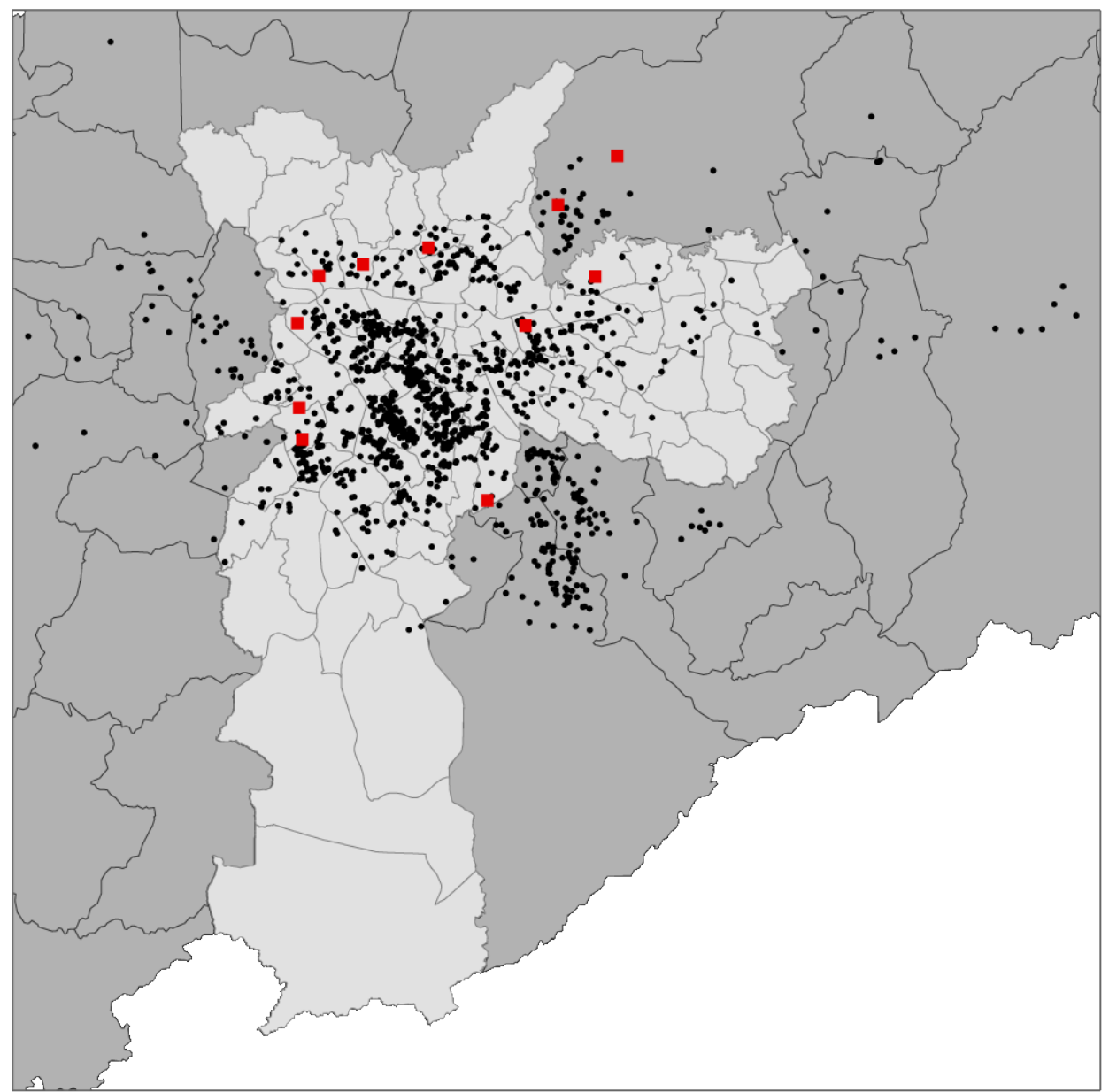

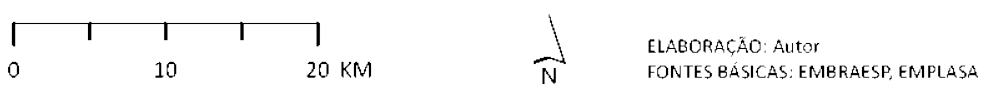

\section{6-2010}

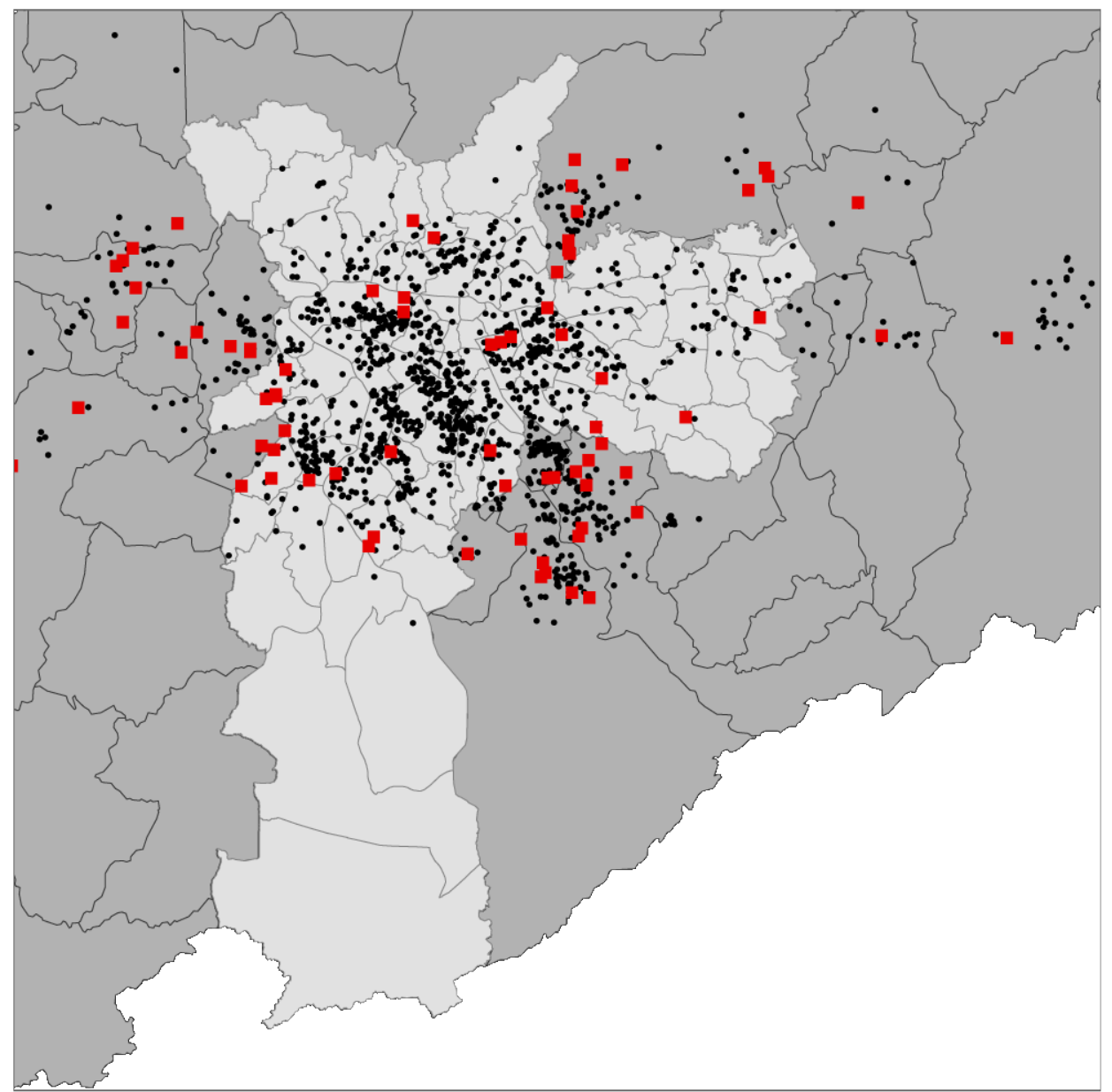

UNIDADES HABITACIONAIS (UHS)/ EMPREENDIMENTO

- $<400$

- $>=400$

MSP_Distritos

RMSP_Municípios 


\section{1-2005}

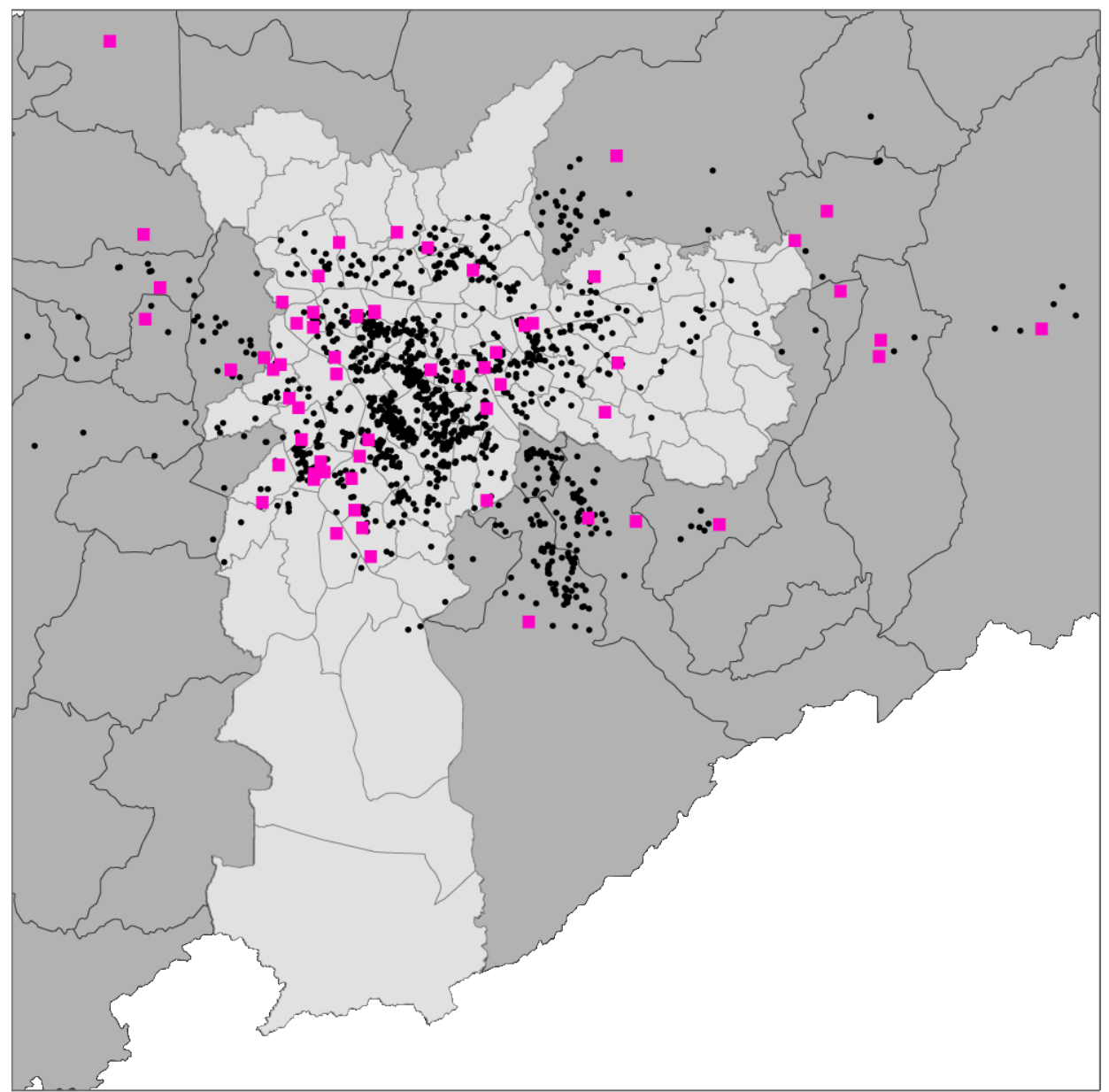

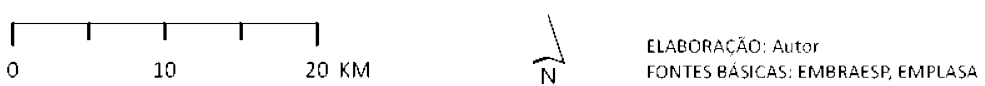

\section{6-2010}

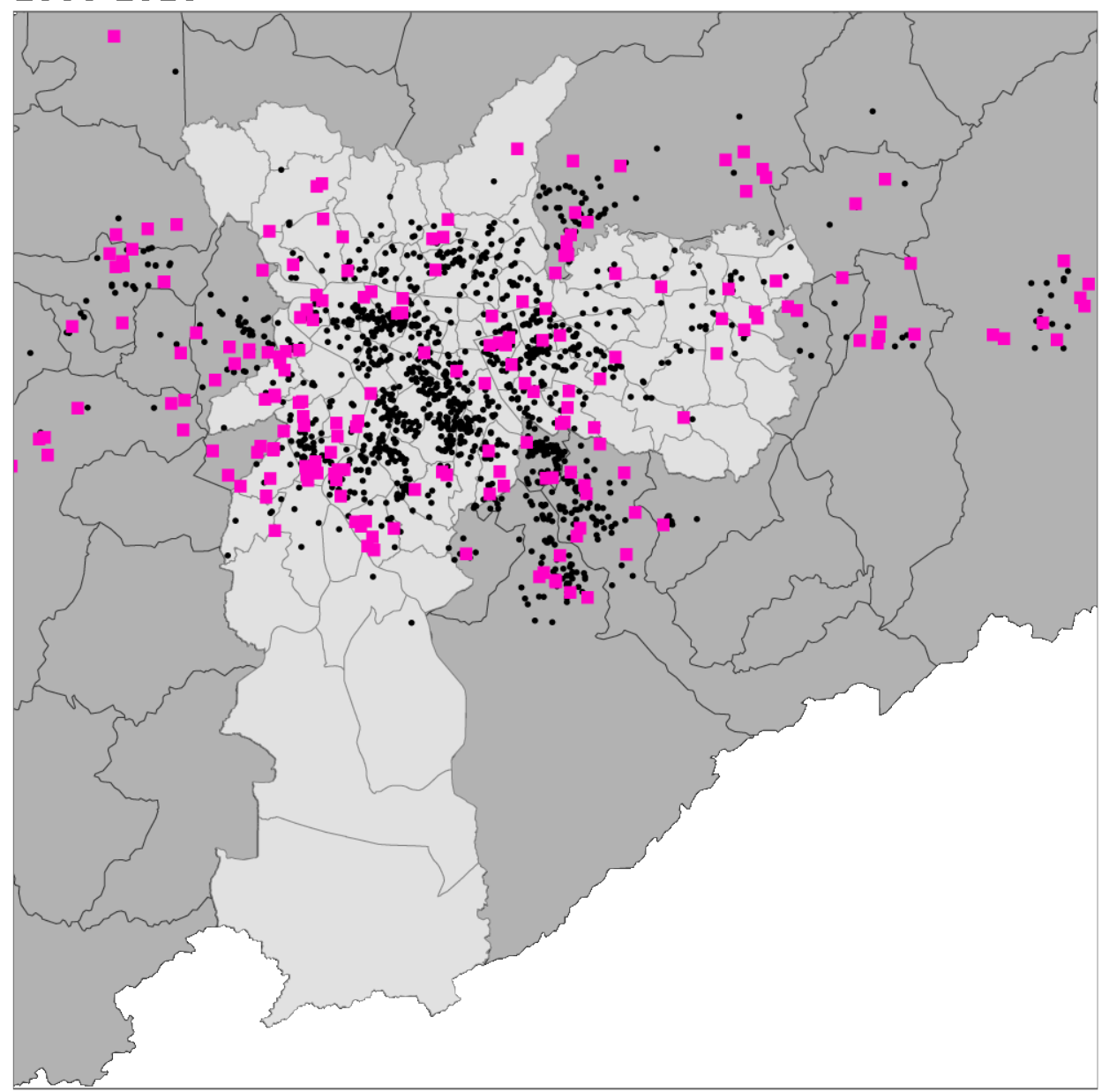

LOTE $\left(\mathrm{M}^{2}\right)$ / EMPREENDIMENTO

$\cdot<10.000$

- $>=10.000$

MSP_Distritos

RMSP_Municípios 


\section{1-2005}

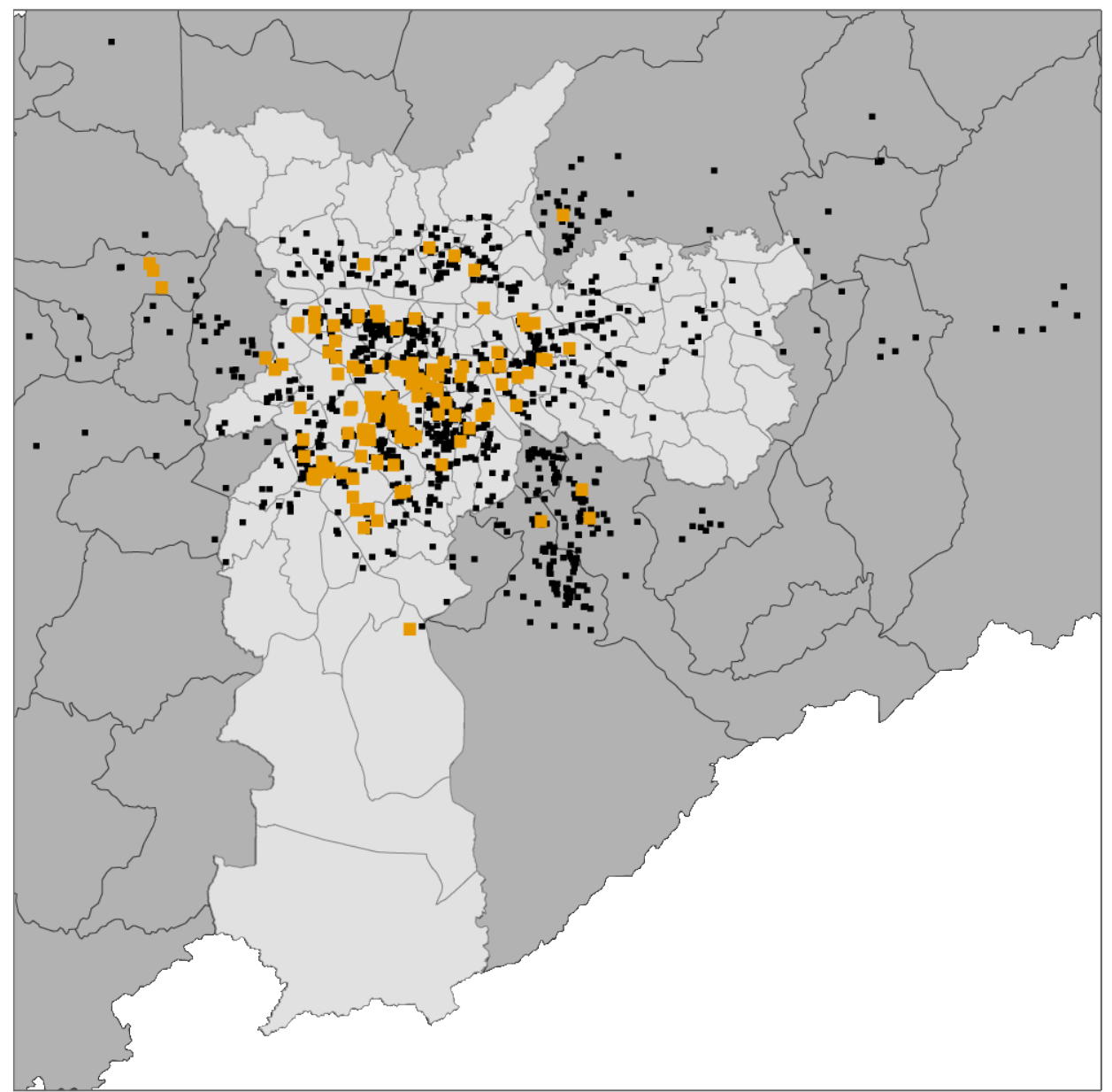

\begin{tabular}{l|l|l}
1 & 1 & 1 \\
0 & 10 &
\end{tabular}
ELABERACĀA: AUtOO

-Valor Geral de Vendas: semelhante a receita bruta.

" Os valores foram trazidos.

Valor Presente (NP) para março/2009

taxa de desconto utili ar toce

\section{6-2010}

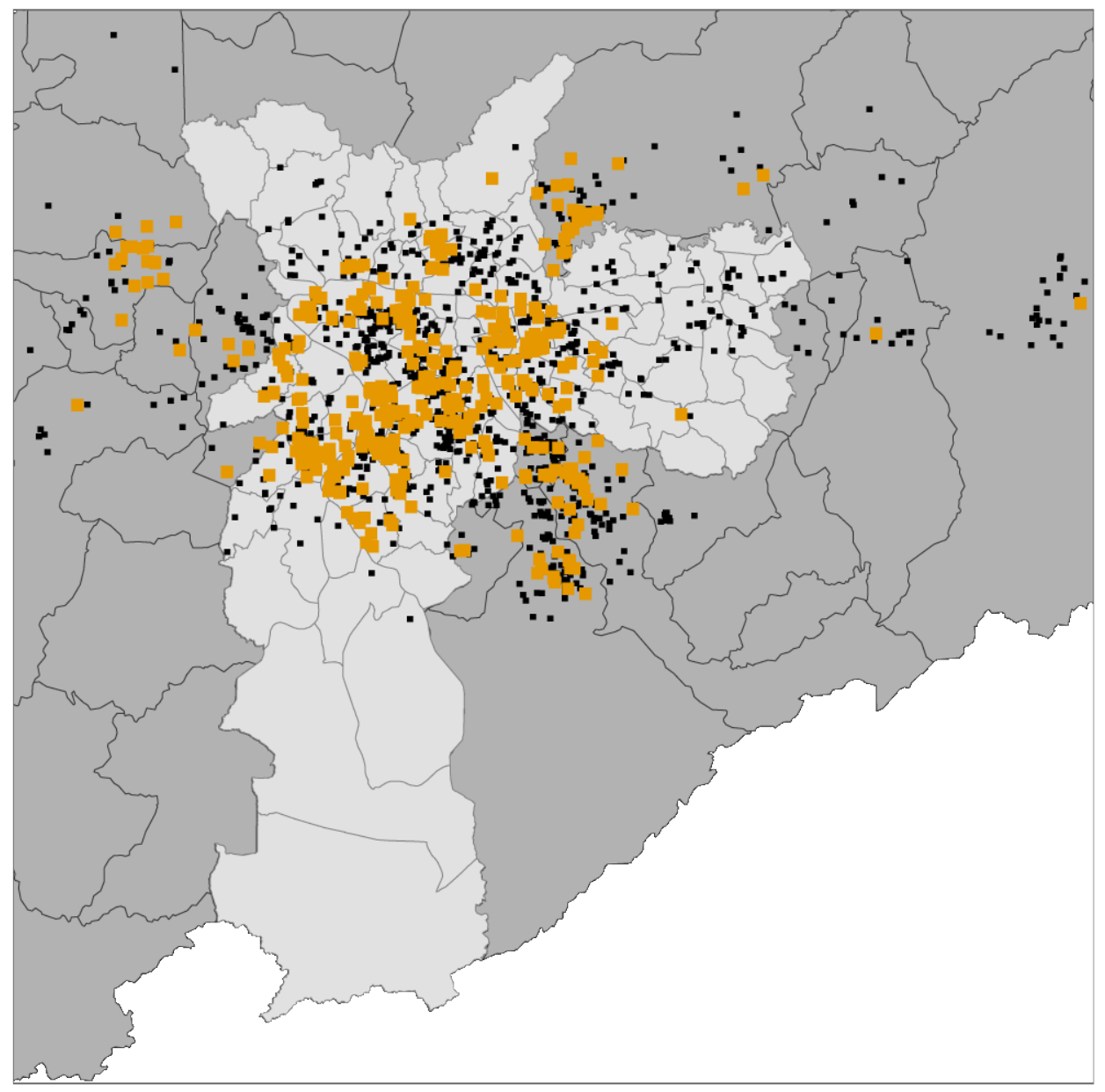

VGV (R\$ MILHÕES)/ EMPREENDIMENTO

- $\quad<50$

- $>=50$

MSP_Distritos

RMSP_Municípios 


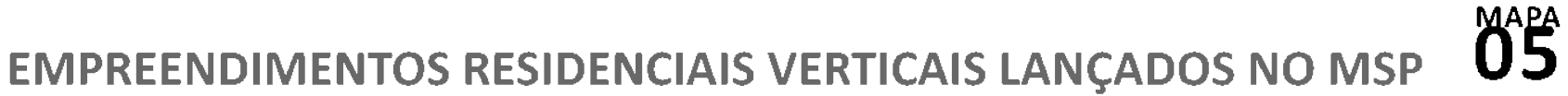

2001-2005

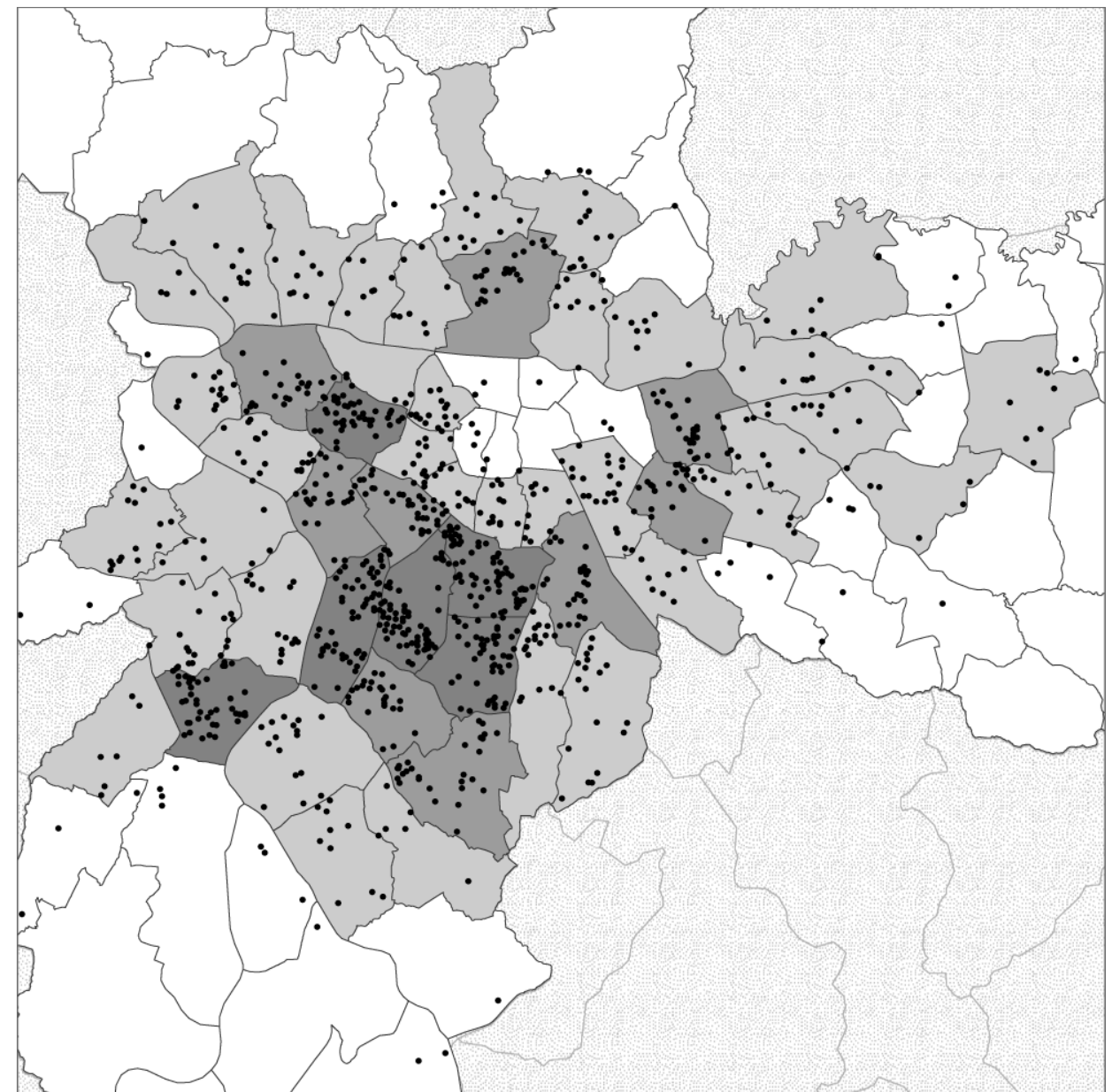

2006-2010

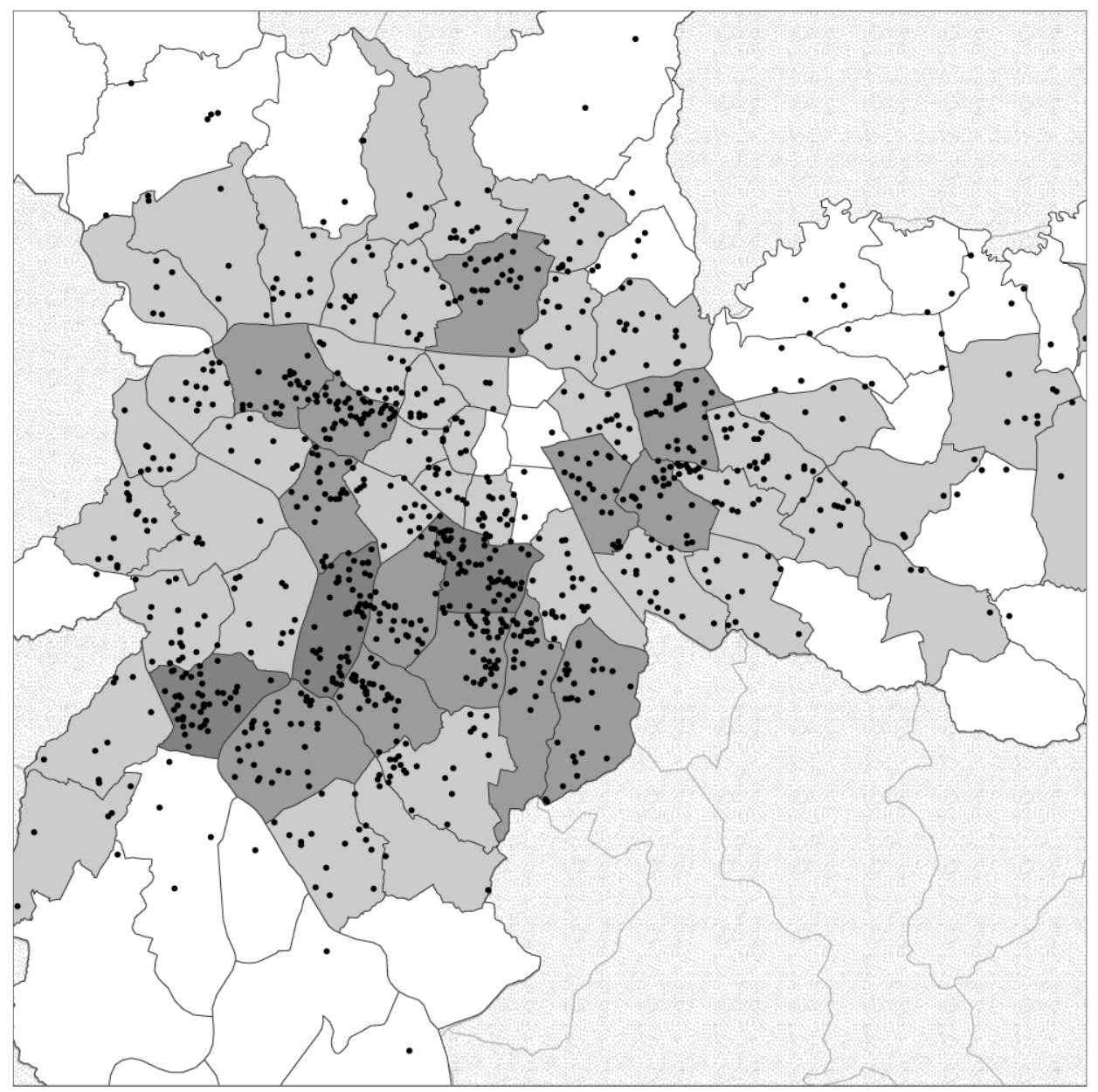

EMPREENDIMENTOS/DISTRITO

$\square-5$

$\square-25$

$26-50$
EMPREENDIMENTO

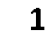

RMSP_Municípios 
2001-2005

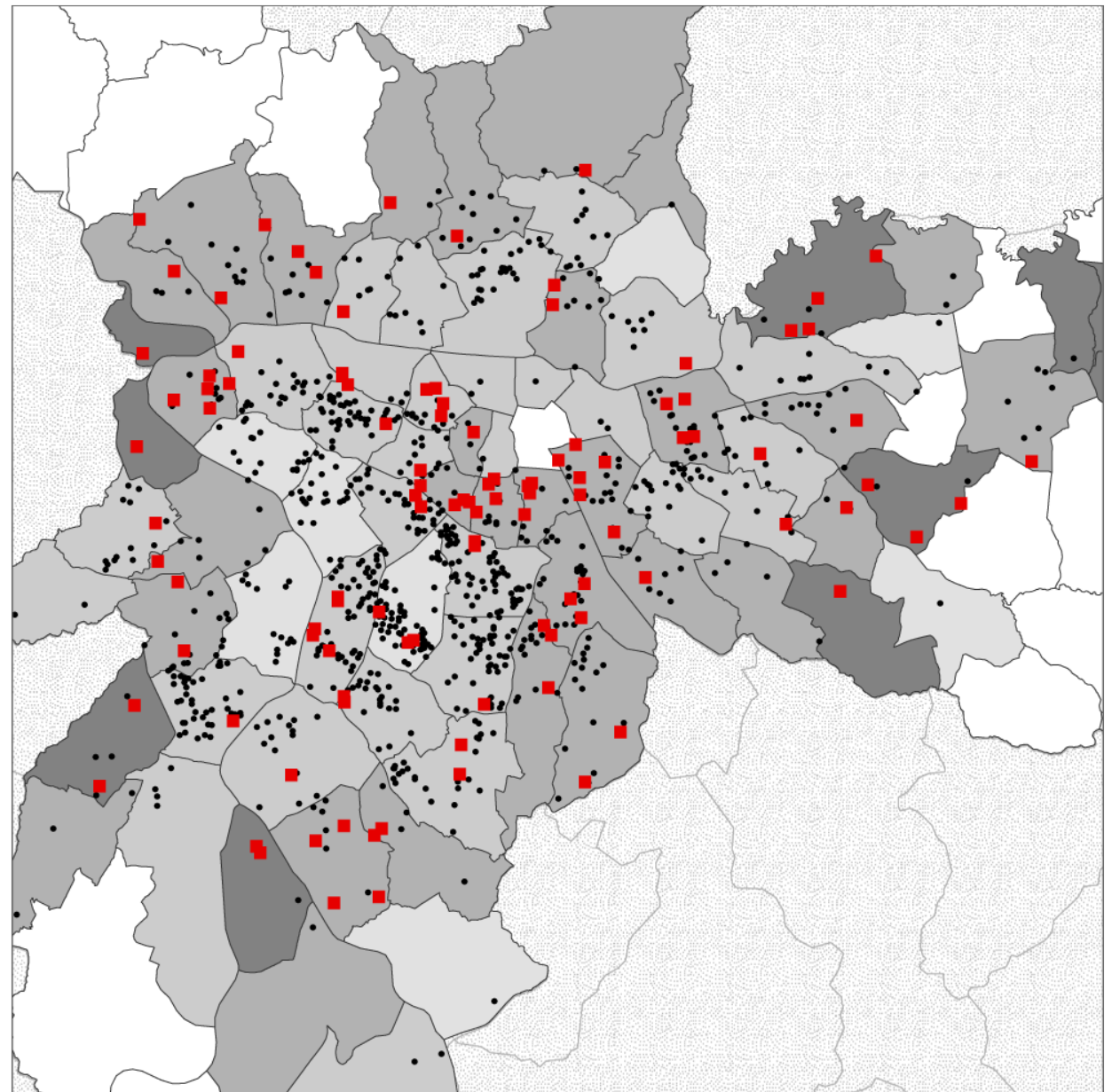

\section{6-2010}

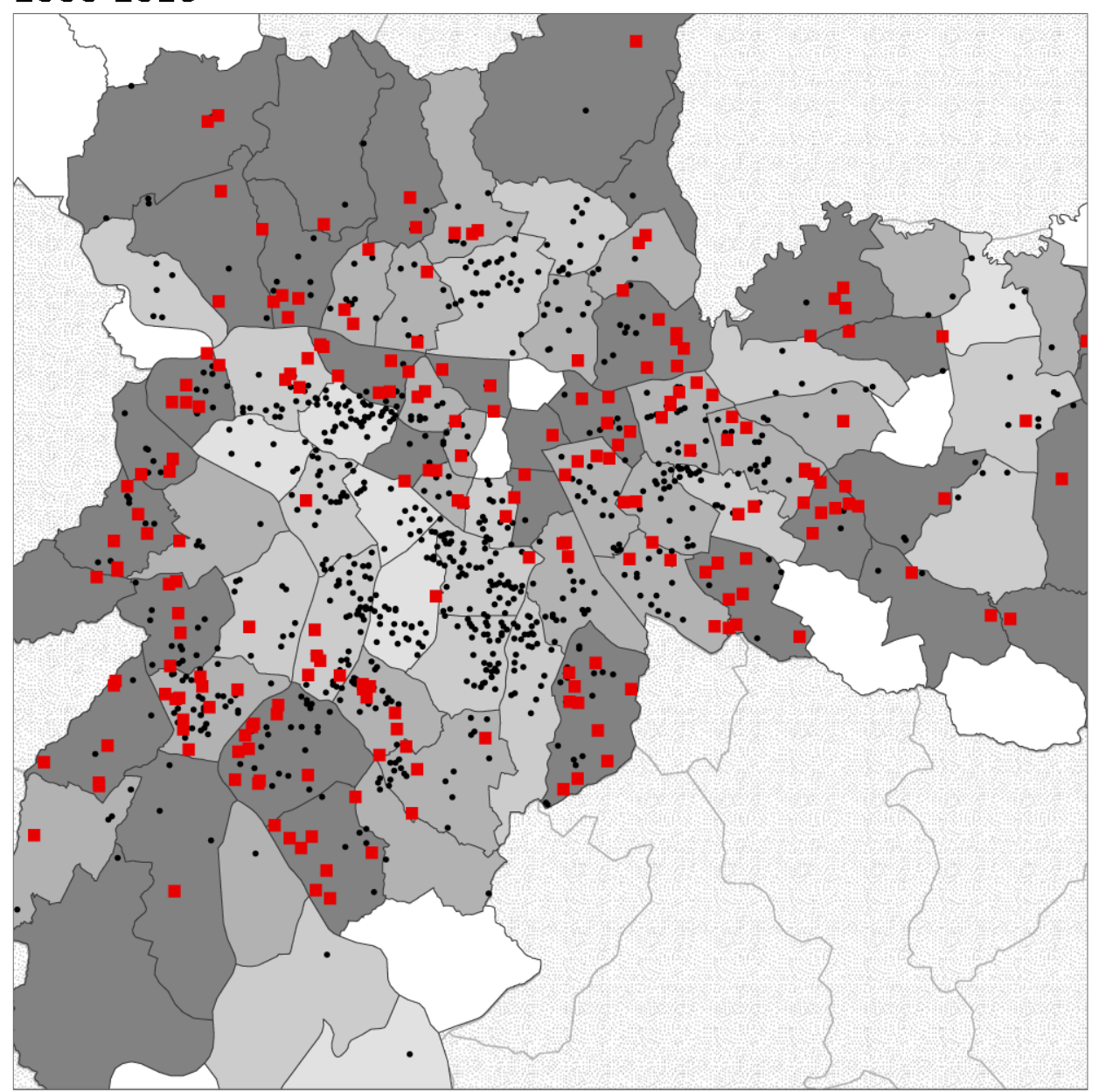

MÉDIA DE UHS POR EMPREENDIMENTO/DISTRITO

UHS / EMPREENDIMENTO

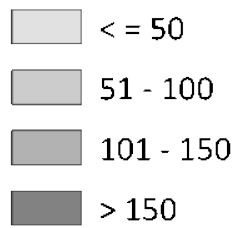

. $<200$

- $>=\mathbf{2 0 0}$

RMSP_Municipios 


\section{1-2005}

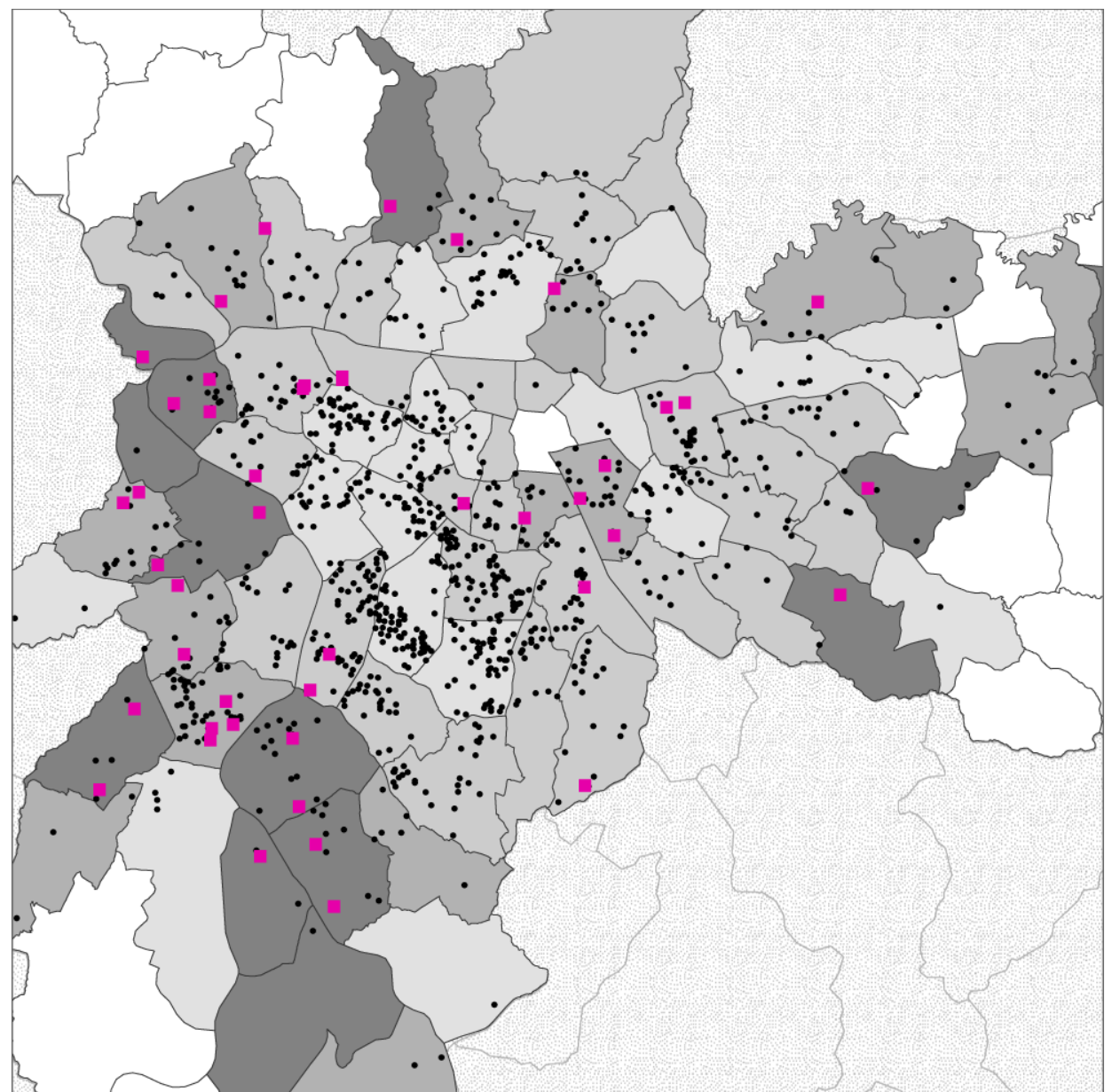

2006-2010

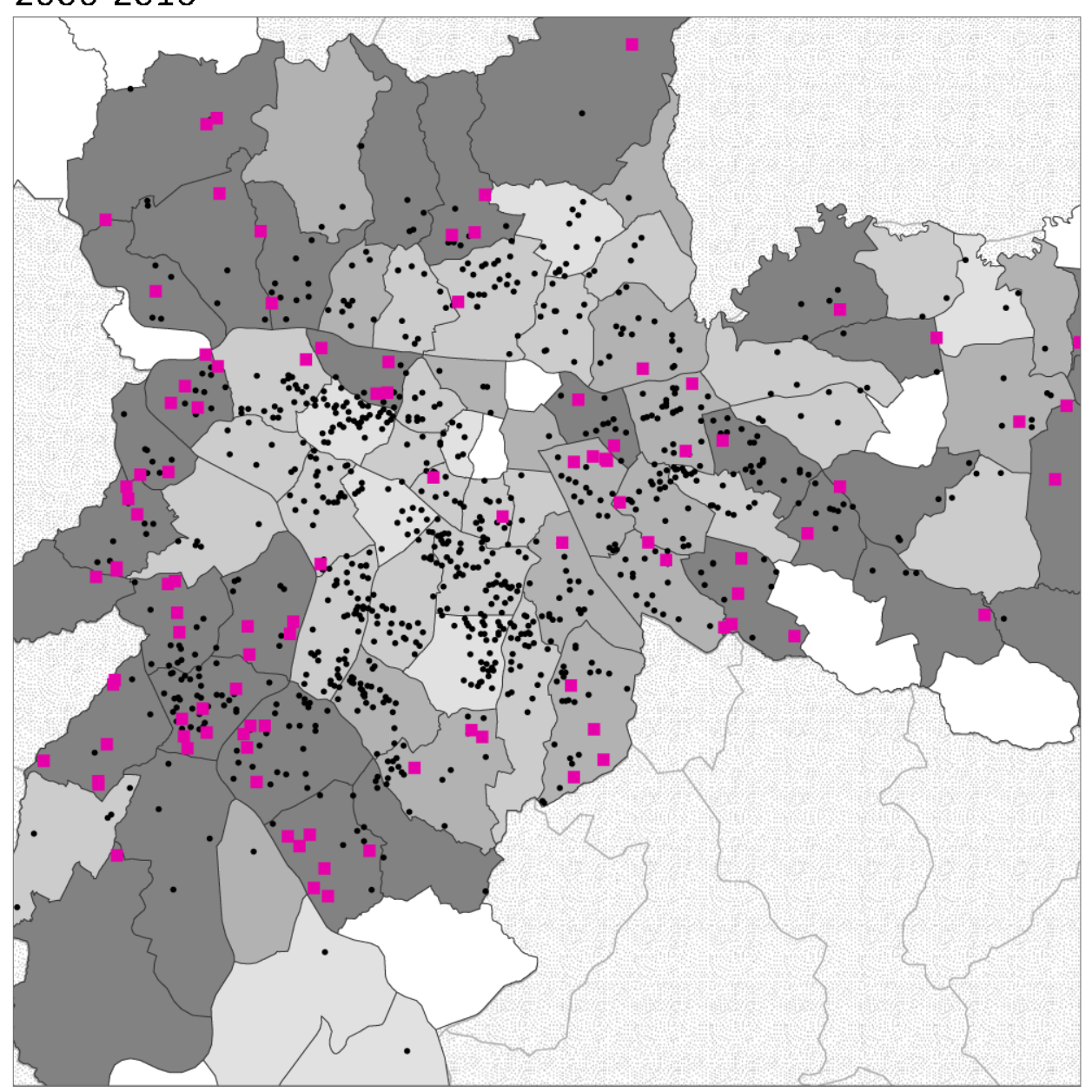

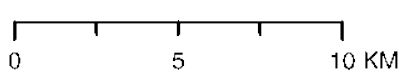

ÁREA MÉDIA DE LOTE $\left(\mathrm{M}^{2}\right)$ POR EMPREEND./ DISTRITO LOTE $\left(\mathrm{M}^{2}\right)$ / EMPREENDIMENTO
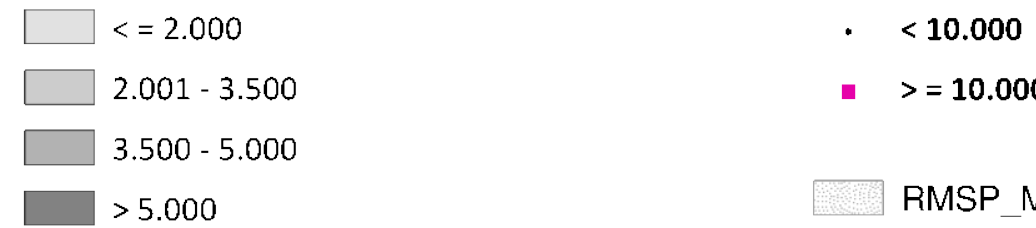

$>=10.000$ 


\section{EMPREENDIMENTOS RESIDENCIAIS VERTICAIS LANÇADOS NO MSP \\ VGV (R\$ MILHÕES) ***/ EMPREENDIMENTO \\ 08}

2001-2005

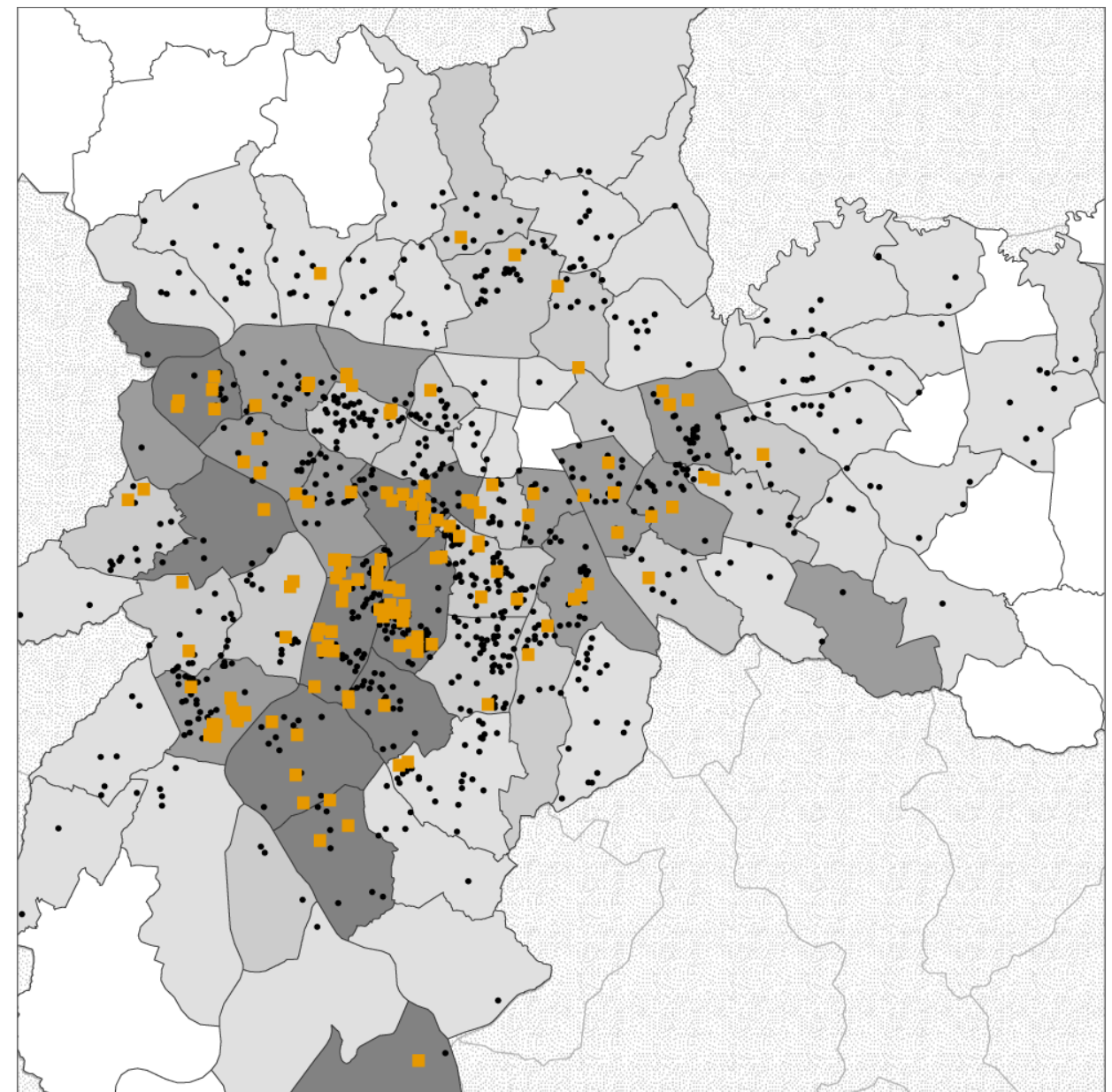

\section{6-2010}

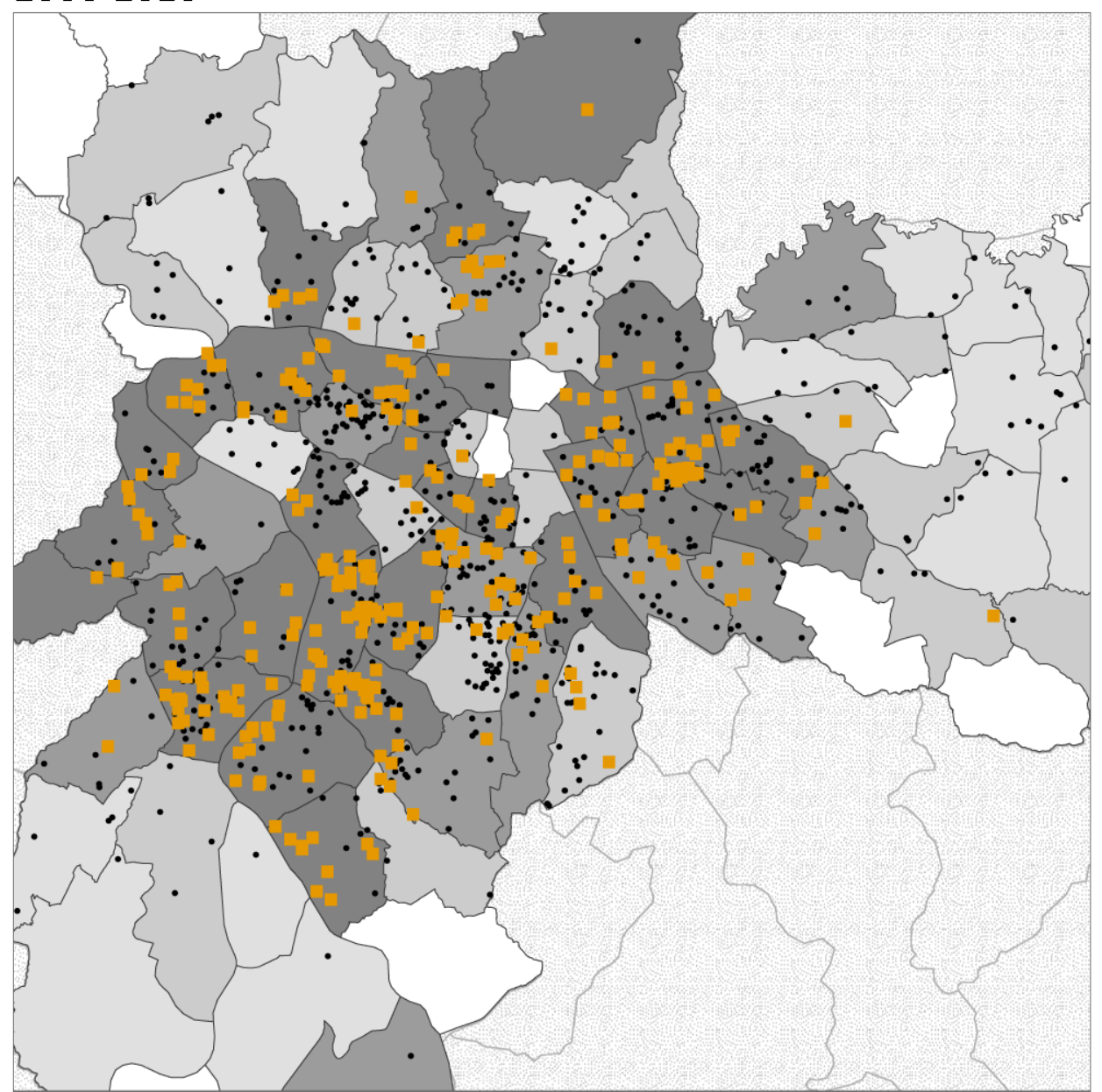

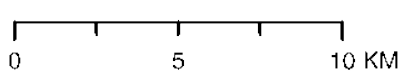

$\frac{\lambda}{N}$

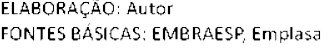

* Valor Geral de Vendas: semelhante a receita bruta. * Os valores foram trazidos a Valor Presente fVPy para marco/2009
Taxa de desconto utilizada: INCC.
VGV MÉDIO (R\$ MILHÕES) POR EMPREEND./ DISTRITO VGV (R\$ MILHÕES)/ EMPREENDIMENTO

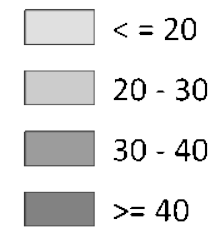

. $<50$

- $>=50$

RMSP_Municipios 


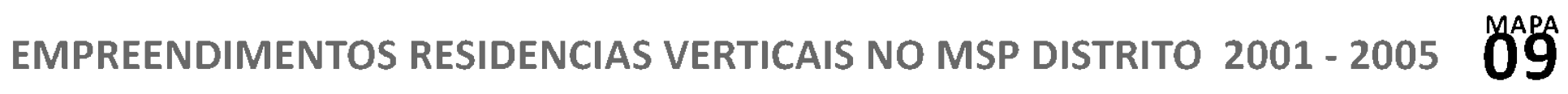
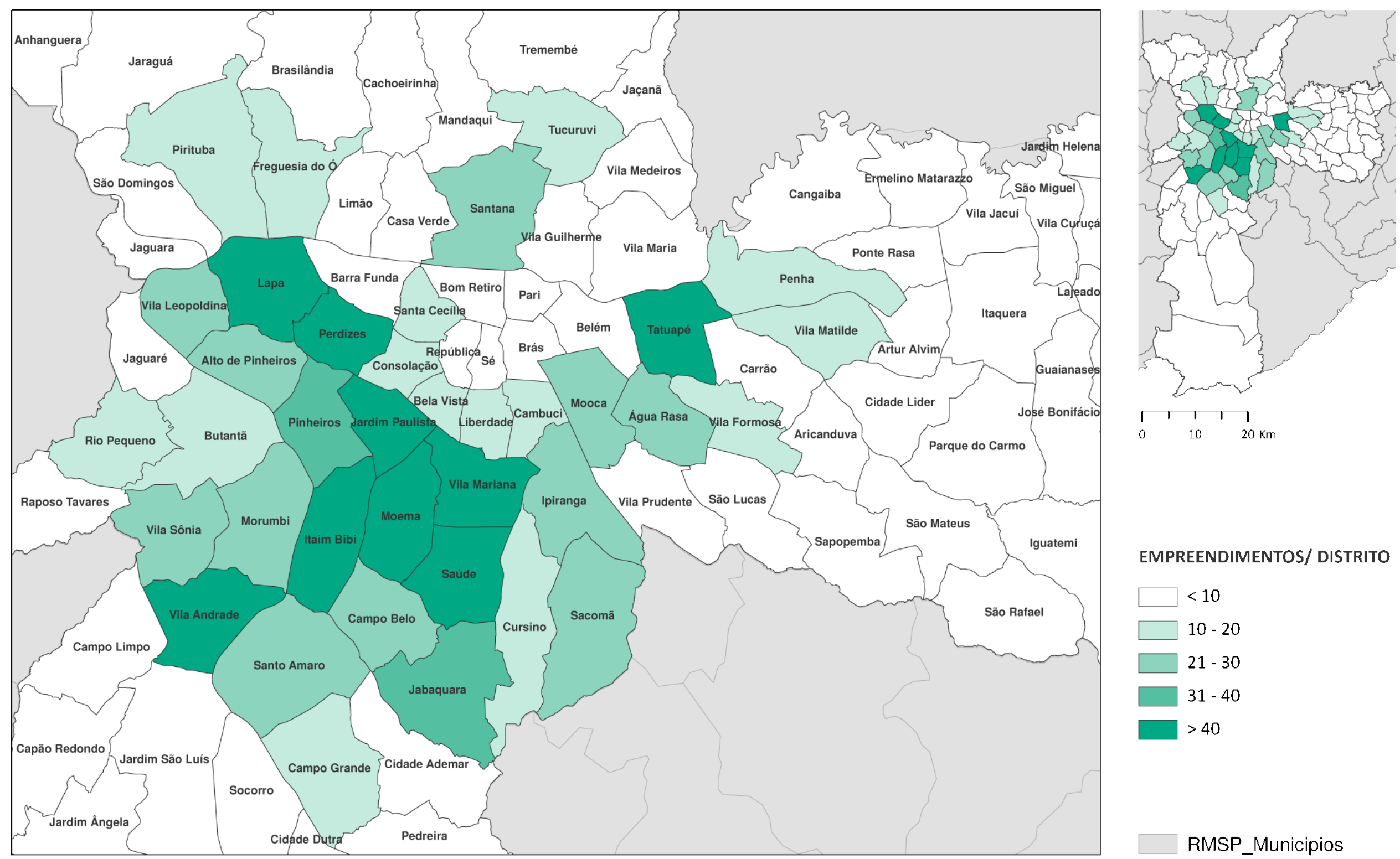

EMPREENDIMENTOS/ DISTRITO

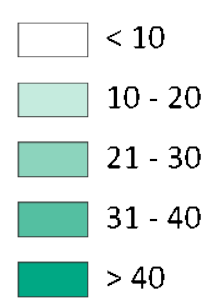

RMSP_Municipios 
EMPREENDIMENTOS RESIDENCIAS VERTICAIS NO MSP DISTRITO 2006 - 2010

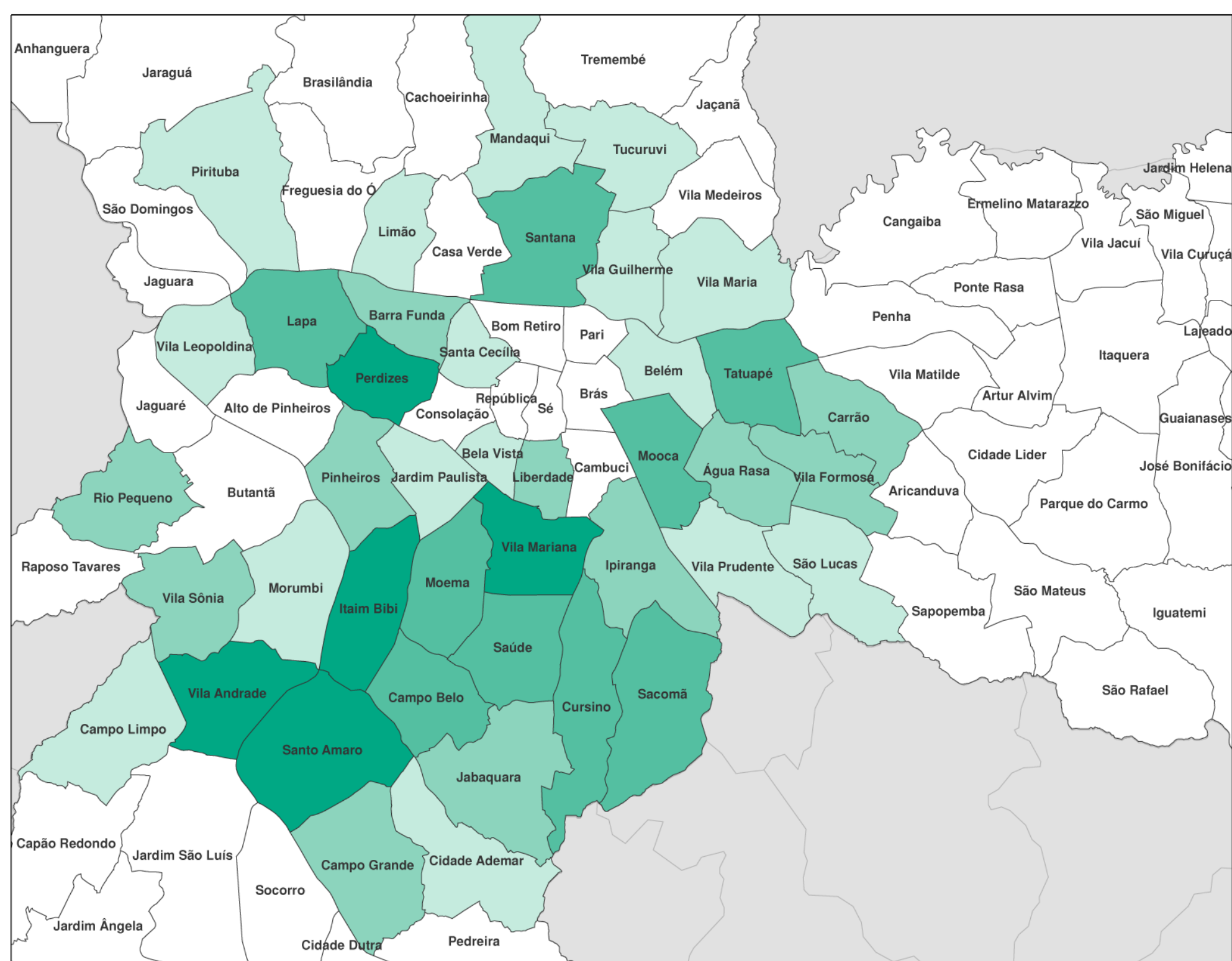

(10

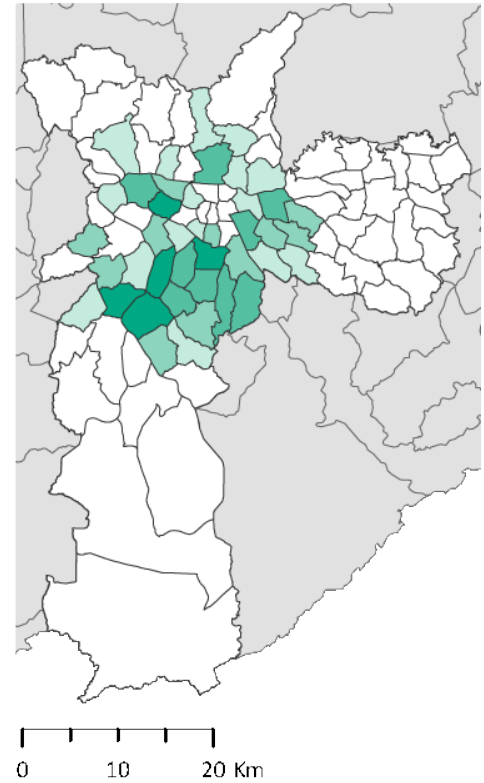

EMPREENDIMENTOS/ DISTRITO

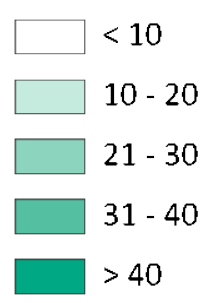

RMSP_Municipios 

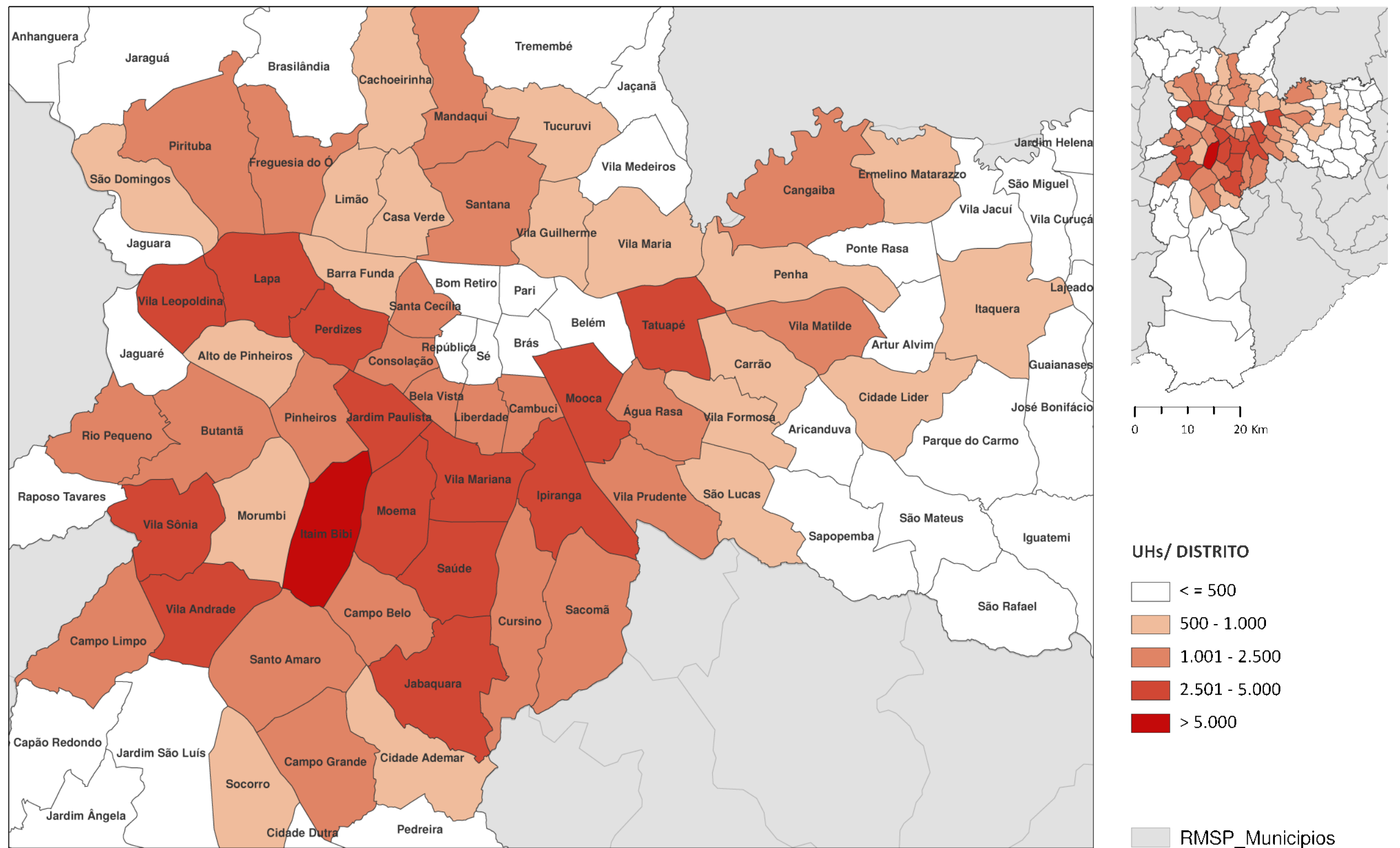

\section{UHS/ DISTRITO}

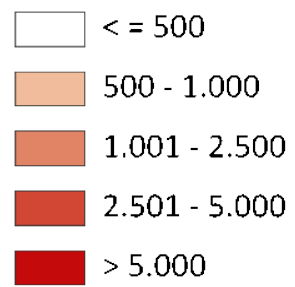

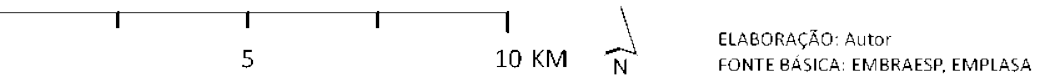




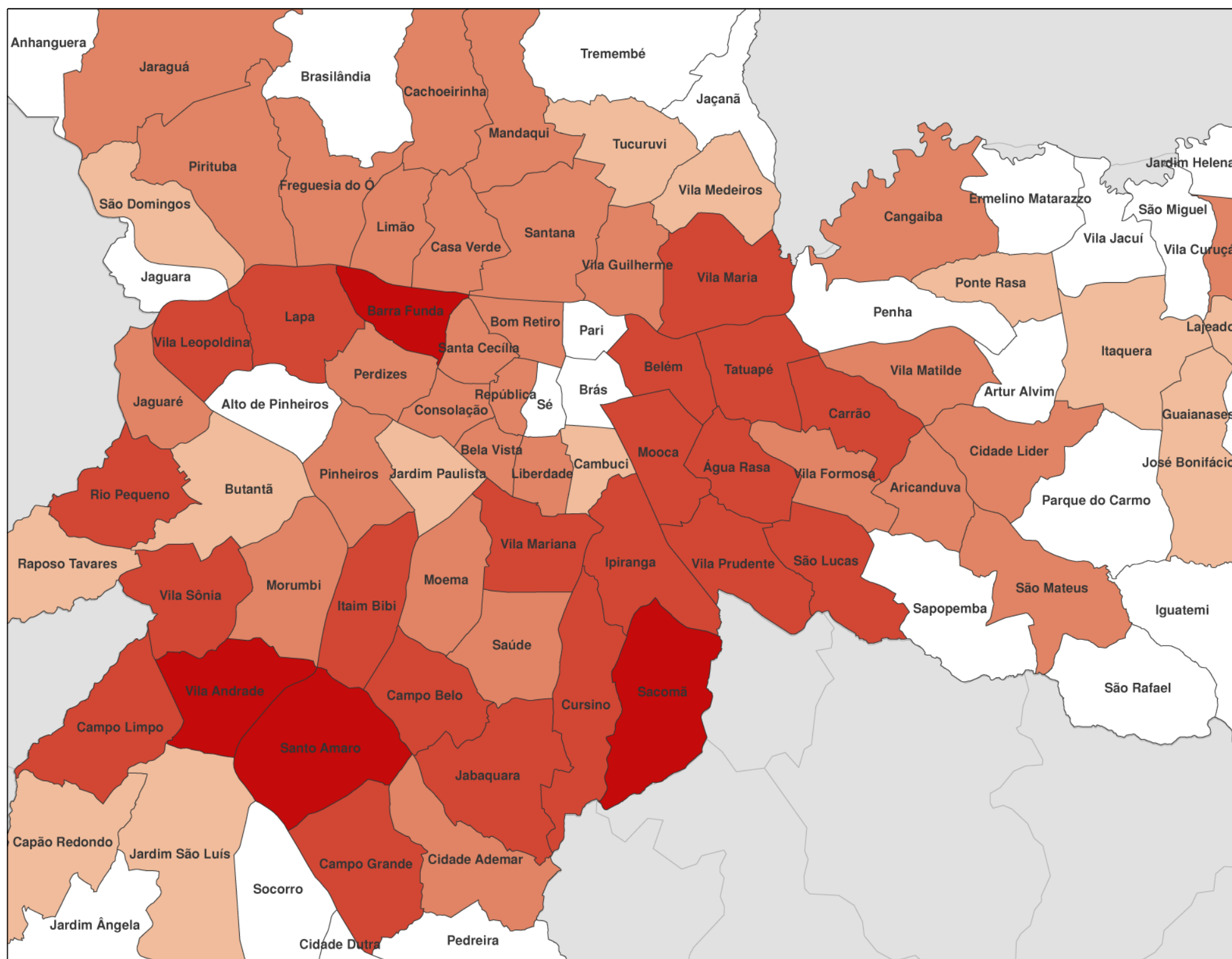

$10 J$ ELLBORAGAOA: AUtO

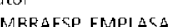

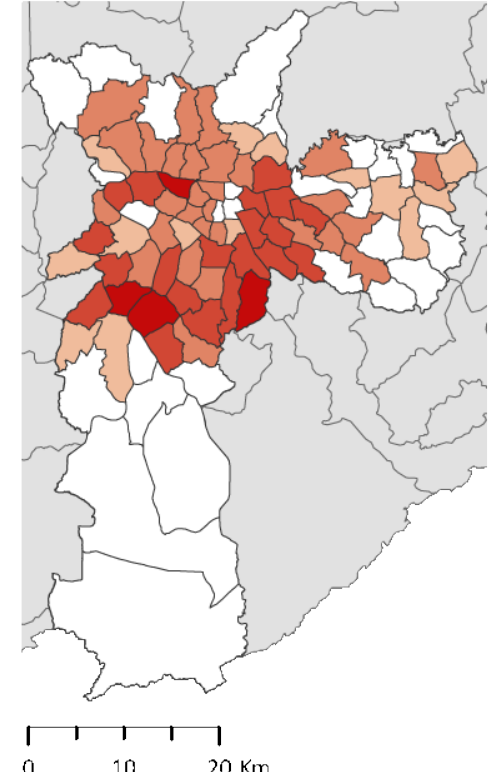

UHs/ DISTRITO

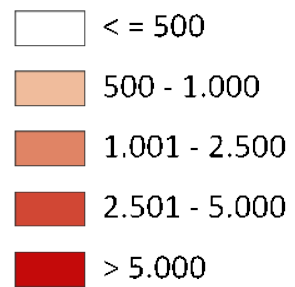

RMSP Municipios 


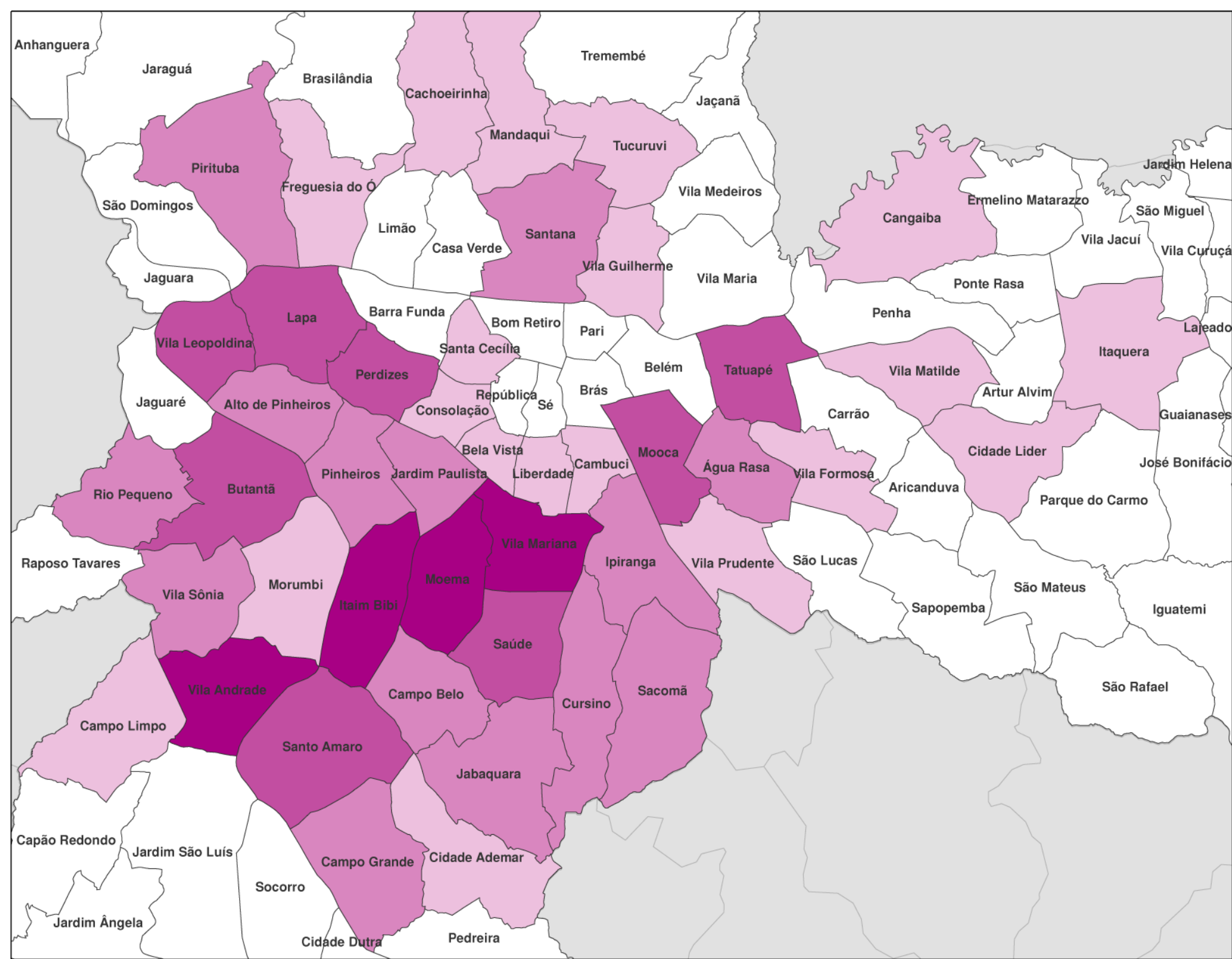

$10 \mathrm{KM} J$ Elaboraç̄o: Auto

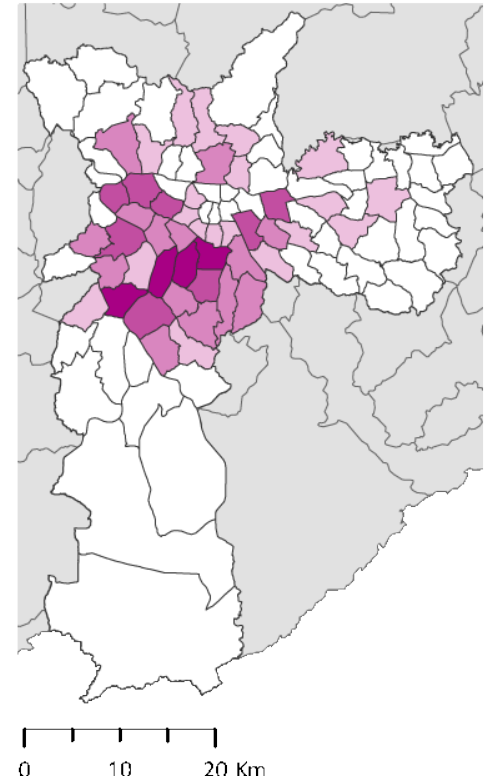

LOTES INCORPORADOS $\left(\mathrm{M}^{2}\right) /$ DISTRITO

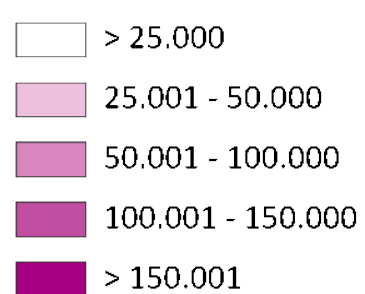

RMSP_Municipios 


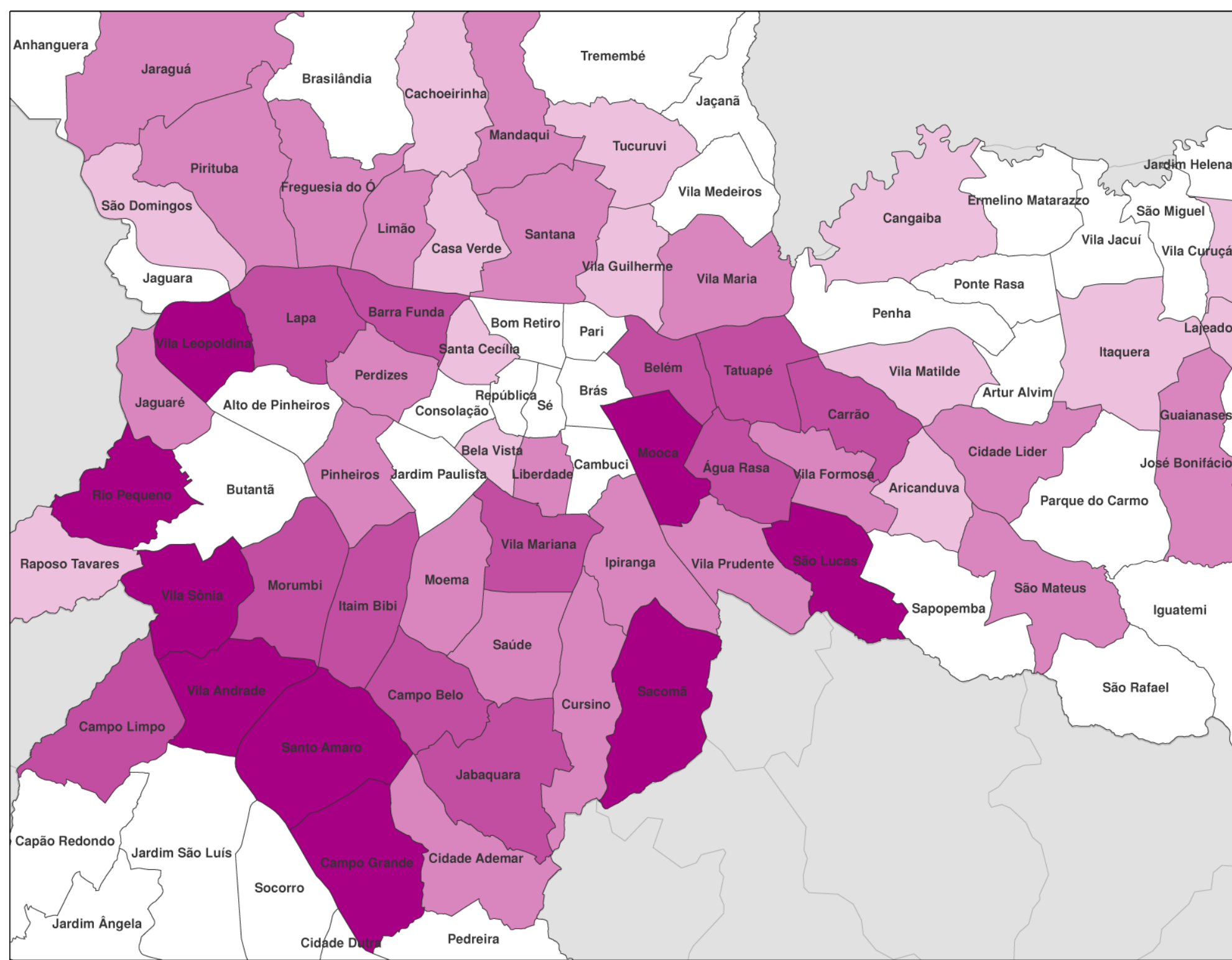

ELAGORAGäo: Autor

$10 \mathrm{KM} A$ ELABORAÇ̌̃O: Autor

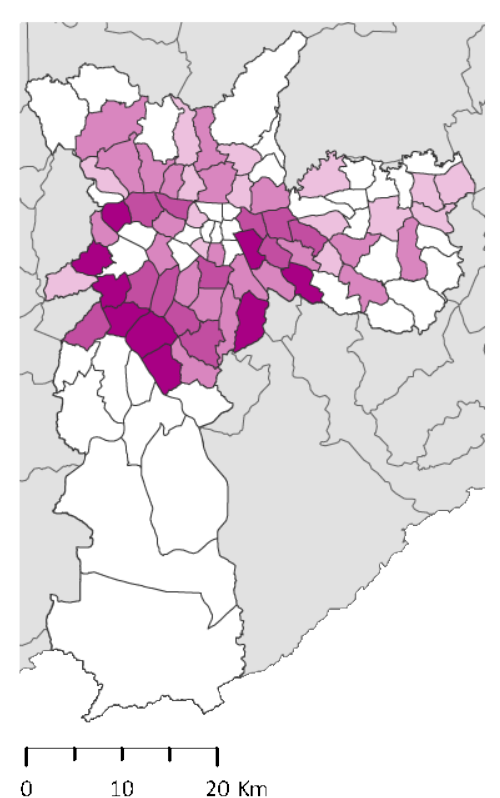

LOTES INCORPORADOS $\left(\mathrm{M}^{2}\right)$ / DISTRITO

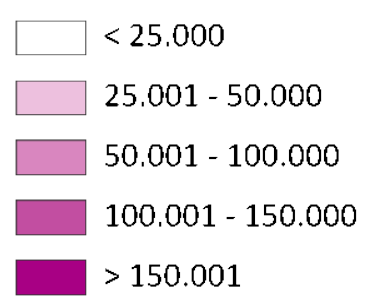

RMSP_Municipios 


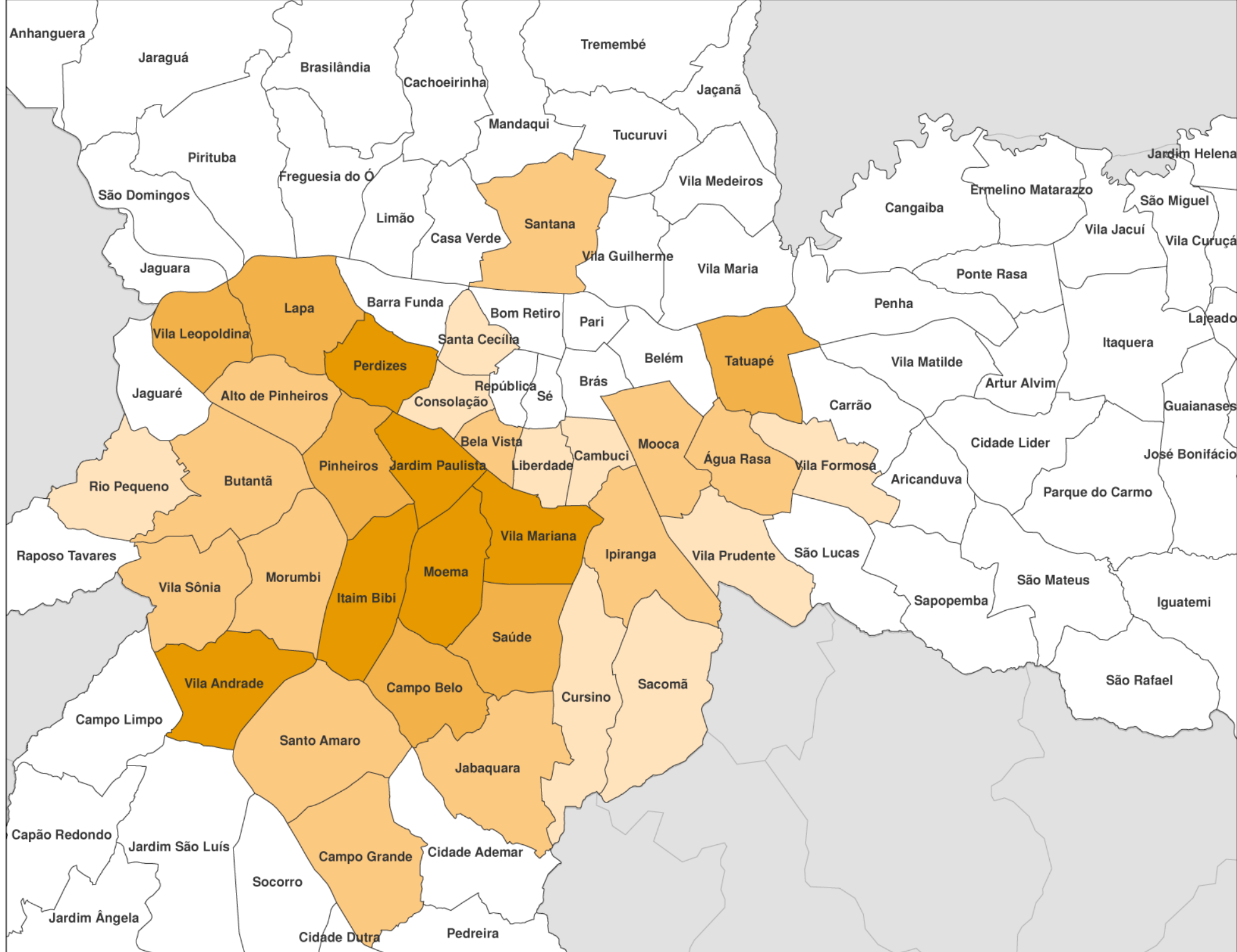

KM Elaboraça: Auto

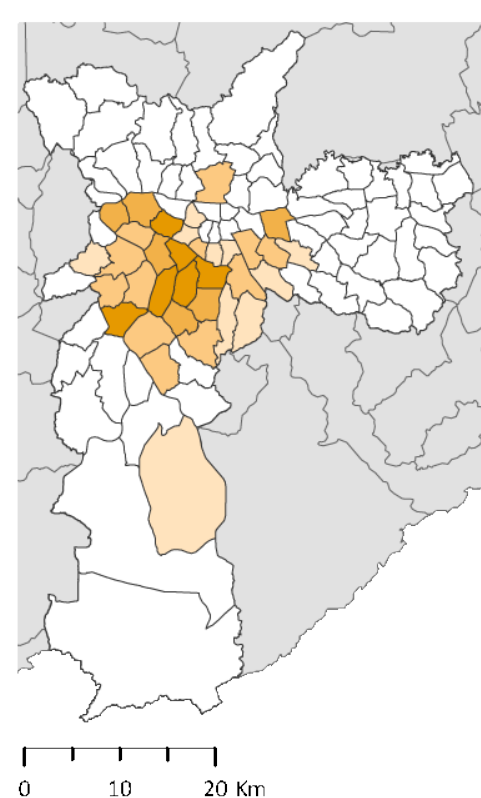

VGV (R\$̣ MILHÕES)/ DISTRITO

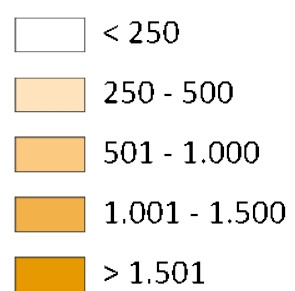

- Valar Geral de Vendas: semelhante a receita brut. OS valores foram trazidos a

Valor Presente (VP) para marco/2009. Taxa de desconto utilizada: INCC.

RMSP_Municipios 


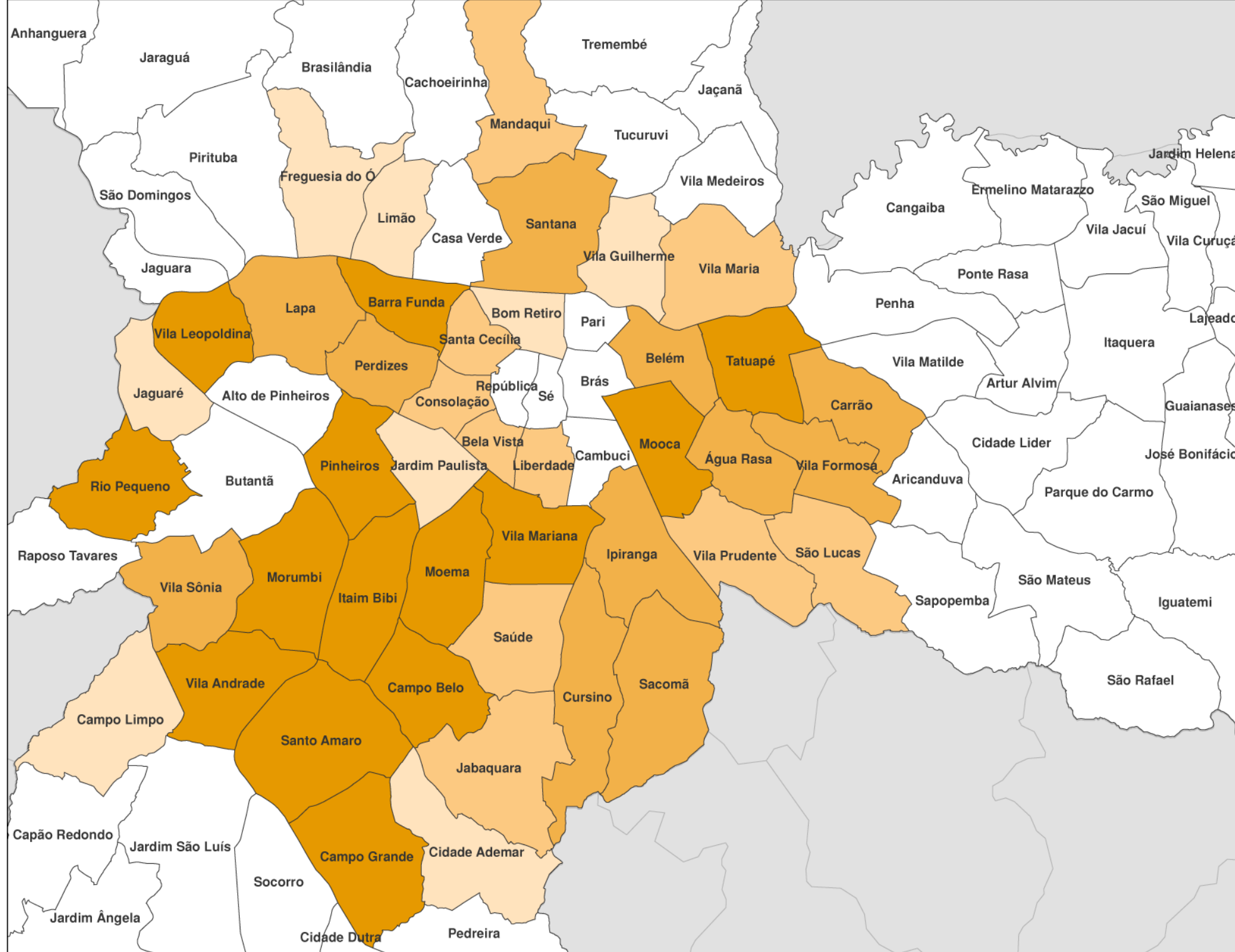

KM Elaboraç̃o: Auto

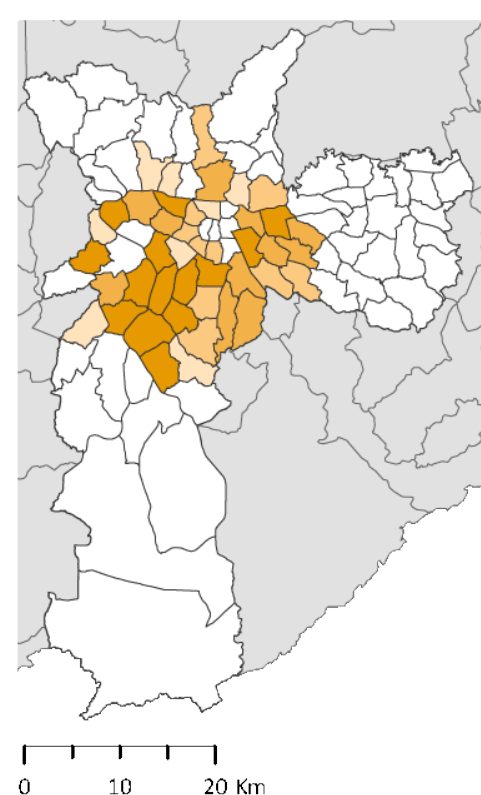

VGV (R\$̦ MILHÕES)/ DISTRITO

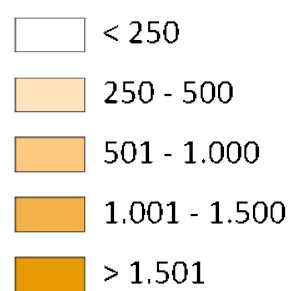

* Valor Geral de Vendas: semelharte a receita bruta. Vos valores foram trazidos

Valor Presente (VP) para marco/2009: xa de desconto utilizada: INCC.

RMSP_Municipios 


\section{CAPÍTULO 04 - A LÓGICA IMOBILIÁRIA E A LEI}

Se o cumprimento da lei por meio dos processos de aprovação e fiscalização é regra à atividade imobiliária, a simples existência dos supercondomínios é suficiente para afirmar, no mínimo, a conivência da legislação para com este modelo de empreendimento. Neste capítulo, mostramos que esta relação é menos de permissividade, o que já justificaria a sua discussão, mas de efetiva condução do resultado formal - dada a lógica vigente que orientou a atividade imobiliária durante o Boom.

O foco desta análise será específico às leis que incidem sobre a estrutura e o aproveitamento do lote e que se relacionam, direta ou indiretamente, com as tendências formais que caracterizam a expansão dos supercondomínios: aumento no porte dos lotes, aumento no número de unidades por empreendimento, e a oferta de espaços de uso comum. Destaco que o marco regulatório edilício relaciona-se com o fenômeno em diferentes níveis e com diferentes intensidades, que não àqueles ligados tão somente à concepção física do empreendimento. Por exemplo, no MSP, vemos que a disponibilidade de grandes lotes urbanos desocupados, matéria prima para a realização dos supercondomínios, esteve também relacionada à desmobilização das áreas industriais pelo governo estadual (Lei no 9.999/98), com o fim das restrições à ocupação, e pelo governo municipal (Lei Municipal 13.885/04 e 13.430/2002 - PDE), com a mudança do zoneamento. Leis que contribuíram para dar a dimensão territorial do fenômeno, mas não condicionaram a forma de apropriação do lote. 
As leis aqui discutidas se inserem em dois ramos do direito: o direito urbanístico e o direito ambiental; e nas esferas federal e municipal do governo - neste último restrinjo a análise à legislação dos municípios de São Paulo, Guarulhos, São Bernardo do Campo, por concentrarem cerca de $80 \%$ da produção habitacional na década de 2000. O direito urbanístico, ramo que compreende as leis de parcelamento do solo (LPS) e as leis uso e ocupação do solo (LUOS), entre outras, é aquele que exerce maior influência sobre a configuração da edificação e é onde concentro esta análise.

\section{1 - A LEI E O AUMENTO DA ÁREA DO LOTE}

Se a opção pela incorporação de lotes maiores durante o Boom imobiliário foi consequência de uma estratégia adotada pelos promotores imobiliários, esta não encontrou entraves na legislação edilícia.

A ausência de dimensões máximas para os lotes urbanos em geral, ou aqueles que servirão para a construção de condomínios residenciais verticais, é comum a praticamente a todas as leis que incidem na atividade imobiliária. Tem início nas leis de parcelamento do solo urbano (LPS), onde são originados os lotes, e passa pelas leis de uso e ocupação do solo (LUOS), onde é regulamentada a edificação. Qualquer uma delas que o tivesse feito teria sido suficiente para controlar (ou limitar) o aumento do porte dos empreendimentos.

A LPS federal no 6766/1979, revista pela Lei o 9.785/1999, é responsável por disciplinar o parcelamento do solo urbano por meio de diretrizes gerais, que poderão ser complementadas e parametrizadas pelos estados, distrito federal e municípios, segundo as particularidades locais. A respeito do porte do lote, esta estabelece que os lotes resultantes do parcelamento tenham área mínima de 
$125 \mathrm{~m}^{2}$ (Art.4ํ), podendo ser maior ou menor em caso de áreas para fins de interesse social, conforme decisão municipal, mas não regulamenta a área máxima do lote.

O Art. 7o indica que a Prefeitura Municipal ou o Distrito Federal, estabeleça, caso a caso, parâmetros formais específicos a serem seguidos pelo loteador; como traçado básico, localização de equipamentos urbanos, áreas livres de uso público e faixas sanitárias, mas novamente não menciona o dimensionamento máximo dos lotes como ponto a ser regulamentado. Esta fase de instrução do projeto de loteamento, chamada de fixação de diretrizes é inclusive dispensada para municípios com menos de cinquenta mil habitantes e para aqueles cujo plano diretor contemple diretrizes de urbanização.

No Município de São Paulo, o Plano Diretor Estratégico (PDE-MSP), Lei no 13.430/02, não especifica diretrizes gerais de parcelamento. Cabe à Secretaria de Habitação (SEHAB), através do Departamento de Parcelamento do Solo e Intervenções Urbanas (PARSOLO), a fixação de diretrizes de parcelamento, bem como aprovar o parcelamento do solo nas modalidades loteamento e desmembramento de gleba. O processo é regulamentado pela Lei $\mathrm{n}$ o $9.413 / 81$, onde não são mencionadas as dimensões máximas admitidas por lote, apenas que os lotes resultantes atendam às dimensões mínimas para a zona de uso na qual se localizam (Art. 14). A exceção fica por conta da Lei № 13.885/04, que estabeleceu normas complementares ao PDE, e limitou a área máxima do lote edificado é limitada a $10.000 \mathrm{~m}^{2}$ em Zonas Especiais de Interesse Social - 3 (ZEIS-3). Segundo Maria Lucia Tanabe, arquiteta da Secretaria de Habitação (SEHAB) da Prefeitura de São Paulo e diretora do PARSOLO quando ocorreu a revisão desta lei (2004), esta exceção decorreu de uma solicitação da Companhia Metropolitana de Habitação (COHAB-SP), na revisão da legislação de uso e ocupação do solo, 
após constatação de maior incidência de problemas de gestão em conjuntos habitacionais que superavam esta dimensão de lote - uma possível prova das consequências que o aumento dos supercondomínios pode trazer.

No Município de Guarulhos, a Lei no 6253/07, que regulamenta o Plano Diretor de Desenvolvimento Urbano, Econômico e Social do Município de Guarulhos (Lei no 6.055/04) prevê limitação de lote em $20.000 \mathrm{~m}^{2}$, apenas ao conjunto residencial horizontal, (categoria R3-II) sendo ilimitado no caso de conjunto residencial vertical (R4-II). Em São Bernardo do Campo, a Lei № 5716/07, que regulamenta o Plano Diretor do Município, (Lei no 5.593/06, em substituição da Lei Municipal № 4434/1996) também não define área máxima do lote.

Ainda que as LPS pareçam exercer menor influência na concepção dos supercondomínios que as LUOS, uma vez que, como observado na espacialização dos supercondomínios, este se caracteriza pela incorporação de áreas dentro da mancha urbana, loteadas há décadas, estas leis, ao não adotar a área máxima de lote, consentem a montagem de grandes lotes por meio do remembramento, uma das alternativas praticadas pelos promotores imobiliários para viabilizar a estratégia dos grandes VGVs, prática observada em distritos paulistanos como Vila Andrade, Vila Sônia e Morumbi.

No caso da legislação paulistana, observa-se ainda o incentivo ao remembramento de lotes, adotando como instrumento estimulador a concessão de potencial construtivo adicional gratuito. A Lei Municipal № 11.732/95, que aprova a Operação Urbana Faria Lima, teve como diretriz estimular o remembramento de lotes e, para isso, concedeu, de forma gratuita, um incentivo, em áreas de construção computável, igual a $20 \%$ (vinte por cento) da área do lote resultante do remembramento, 
quando os lotes originais tivessem menos de $2.000 \mathrm{~m}^{2}$ e resultassem em lotes acima de $2.500 \mathrm{~m}^{2}$ (Art. 14ㅇ), o que se repetiu na Operação Urbana Consorciada Água Espraiada (Lei municipal № 13.260/01 - Art.

4․ VII). Neste caso, aos lotes resultantes de remembramento acima de $2.500 \mathrm{~m}^{2}$ e $5.000 \mathrm{~m}^{2}$ seria concedida, de forma gratuita, área adicional de construção computável equivalente a $10 \%$ e $20 \%$ respectivamente, respeitando o coeficiente de aproveitamento máximo do Setor (Art. 16ㅇ). Premiar o remembramento de lotes também foi uma diretriz para a Área de Intervenção Urbana (AIU) 23 de Maio (Lei 13.885/04, Art. 72으. III): “incentivar o remembramento de lotes na AIU e a reconstrução nestes lotes".

\section{2 - A LEI E A OFERTA DE ESPAÇOS DE USO COMUM}

A influência da legislação na estruturação dos espaços livres que caracterizam os supercondomínios se dá de duas maneiras: regulamentando a área do lote ocupável que pode ou não ser ocupada, determinando a criação dos espaços livres; e exigindo o atendimento de programa de espaços e equipamentos específicos nos espaços de uso comum, qualificando (e, se necessário, suplementando) os espaços livres criados. No segundo caso, exigências que fundamentam-se no advento da propriedade em condomínio e, por isso, restringem-se aos conjuntos multifamiliares.

Para controlar a ocupação do lote, a LUOS faz uso de dois instrumentos principais ${ }^{74}$ : Taxa e de Ocupação (T.O.) e Coeficiente de Aproveitamento (C.O.). A T.O. indica a relação entre a área da projeção horizontal da edificação ou edificações e a área do lote; e o C.O. indica a relação entre a área construída

74 A legislação também define os recuos mínimos obrigatórios. Como estes tornam-se pouco determinantes, a medida que o lote aumenta, estes instrumentos secundários para a caracterização do fenômeno dos supercondomínios. 
computável de uma edificação e a área total do lote. Foi a parametrização destes índices, considerando o uso pretendido, mas desconsiderando o porte do terreno, que, em conjunto, levou à criação de extensas áreas livres nos térreos dos empreendimentos, em números absolutos, que estimularam a criação de praças, clubes e parques privativos nos supercondomínios.

No Município de São Paulo, a T.O. máxima permitida em zonas onde o condomínios residências verticais (R2V) são permitidos é, via de regra, 0,5. Em Guarulhos, a T.O. máxima varia de 0,5 a 0,7 para condomínios residenciais verticais (R4), dependendo da Zona onde se encontrem, e, em São Bernardo do Campo, a T.O. gira em torno de 0,7. Estas garantem que 50\% (na capital) ou 30\% (em Guarulhos e São Bernardo do Campo) do lote sejam espaços livres. Entretanto, observou-se que os supercondomínios conservam percentuais de ocupação bastante abaixo das T.O. máximas estabelecidas por lei.

No caso da capital, alguns autores atribuem este fato à vigência de um instrumento urbanístico conhecido como a Fórmula de Adiron, inicialmente regulamentado pela Lei no 7.805/72 (Art. 24으) e mantido no PDE-MSP (Art. 166ㅇ), tendo sofrido pequenas alterações desde a sua criação. O instrumento permite que, em zonas específicas, o C.A. básico estabelecido para o lote, possa ser beneficiado de acréscimo, limitado a 1,0 (um), sem o pagamento de contrapartida financeira, caso seja reduzida a T.O. ${ }^{75}$. Por exemplo, em zona Z2, onde o coeficiente básico seja 1 e o coeficiente máximo seja 2, a redução da taxa de ocupação de 0,5 para 0,25 permitiria que fosse utilizado o coeficiente máximo 2 , sem o pagamento de outorga onerosa. Entre as contrapartidas exigidas, 50\% da área livre resultante deverá ser

\footnotetext{
${ }^{75}$ Fórmula $\mathrm{CAu}=\mathrm{TO} / \mathrm{TO} \mathrm{x} \times \mathrm{CAb}$, onde $\mathrm{CAu}=$ Coeficiente de Aproveitamento a ser utilizado/ TOu = Taxa de Ocupação a ser utilizada/ TO = Taxa de Ocupação Máxima admitida/ CAb = Coeficiente de Aproveitamento Básico.
} 
ocupada por jardim e 15\% deverá ser mantida permeável, isto é, sem construção no subsolo. A LUOS de São Bernardo do Campo também prevê instrumento semelhante: "os coeficientes de utilização [semelhante ao C.A.] do terreno ou lote nas Zonas Comerciais "ZC", Corredores Comerciais "CC" e Zonas Especiais de Comércio 'ZEC', poderão ser aumentados até o limite máximo de 4 (quatro) vezes, [sendo o básico 2,5] desde que a taxa de ocupação do lote a ser adotada seja inferior ao máximo permitido para a zona (...)."(Art. 54 - Lei № 4446/ 1996).

ILUSTRAÇÃO 3: TAXA DE OCUPAÇÃO X ESTRUTURAÇÃO DOS ESPAÇOS LIVRES INTRALOTE

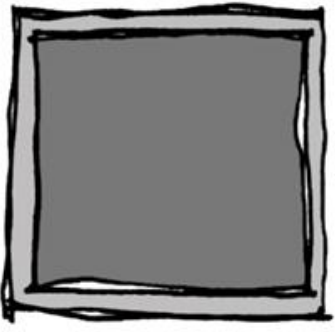

T.0. 100\%

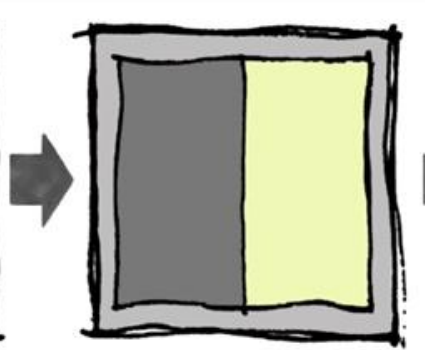

T.0. 50\%

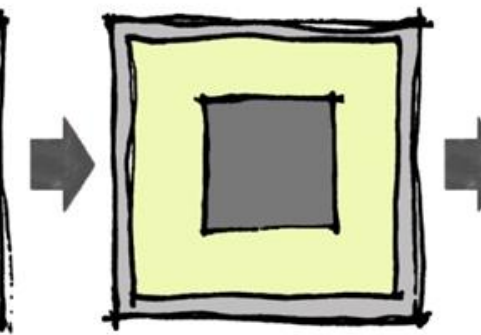

T.0. 25\%

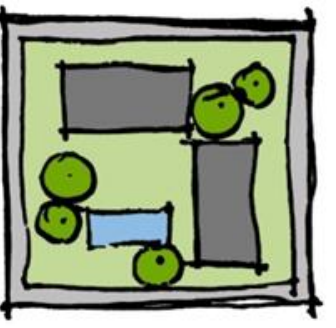

T.0. 25\%

ELABORAÇÃO: Autor

Como o aumento do C.A. costuma coincidir com o potencial imobiliário do terreno, a troca do potencial construtivo adicional pela redução da T.O. é atrativa para o agente imobiliário, particularmente 
para o proprietário do terreno, que definirá o valor de sua propriedade levando em consideração este potencial adicionável ${ }^{76}$.

Mas não são apenas as T.O. praticadas que explicam a liberação dos térreos. Estas seriam mais decisivas nas construções horizontais ou quando há a limitação do gabarito, que impeça uma maior verticalização. Com os C.A. máximos ao redor de 2 no MSP (alcançando 4 em alguns pontos específicos) e 4, em SBC e Guarulhos, nas zonas onde a construção de condomínios residências verticais é permitida, observou-se que, dada a preferência do mercado para a realização de prédios acima de 16 andares (justificando a adoção da alvenaria estrutural e reduzindo o percentual de áreas de uso comum no edifício nos térreos), quando é feita a opção pela verticalização, o aproveitamento total dos C.A. máximos estabelecidos pelas leis, levou a ocupação de pequenas porções do lote, muito abaixo das T.O. definidas. Exemplo disto são os supercondomínios apresentados na ILUSTRAÇÃo xX.

\footnotetext{
${ }^{76}$ Via de regra, o preço que o mercado atribui a um terreno está diretamente relacionado ao seu potencial imobiliário, que por sua vez, está diretamente relacionado à área vendável que ele comporta. Se um determinado lote consente a construção de dez apartamentos de um tipo, dificilmente será economicamente viável construir apenas cinco destes, já que o valor pago pelo terreno, baseou-se na venda dos 10 apartamentos, exigindo que o retorno financeiro das cinco unidades não construídas seja embutido no preço das cinco unidades construídas. Nesta formulação, o Coeficiente de Aproveitamento (C.A.) é o ponto de partida para definir a área vendável e o valor a ser pago pelo terreno: quanto maior o C.A., maior será este valor. No entanto, exigências de espaços de lazer, institucional, ou de vagas de carros, ou disponibilidade financeira reduzida da demanda, podem impedir que o C.A. máximo estabelecido seja alcançado, não sendo o único fator a ser considerado para a identificação do potencial imobiliário e precificação do terreno.
} 
ILUSTRAÇÃO 4: ESTUDO COEFICIENTE DE APROVEITAMENTO (C.A.) E TAXA DE OCUPAÇÃO (T.O.) NOS SUPERCONDOMÍNIOS

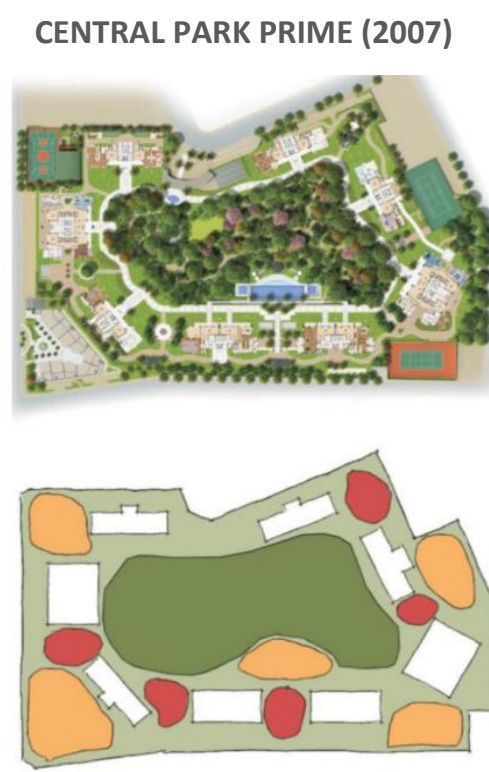

ÁREA : $33.640 \mathrm{~m}^{2}$

T.0.: 0,15

C.A.: aprox. 4
DOMÍNIO MARAJOARA (2007)
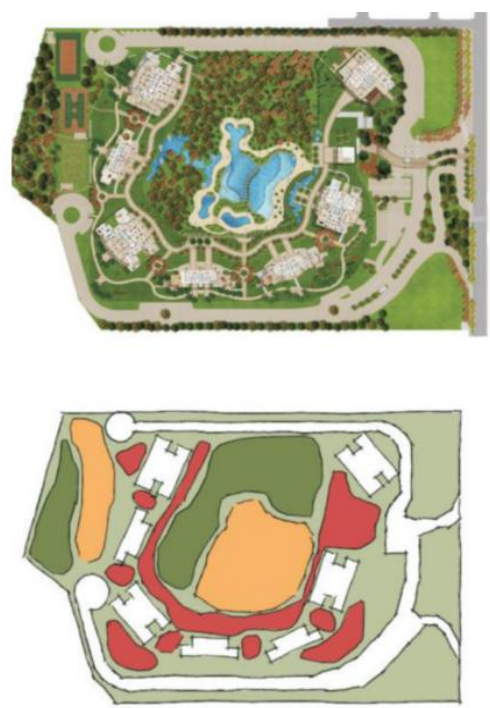

ÁREA : $66.000 \mathrm{~m}^{\circ}$

T.0.:0,1

C.A.: aprox. 2.5
ESPAÇO RAPOSO CLUBE (2006)
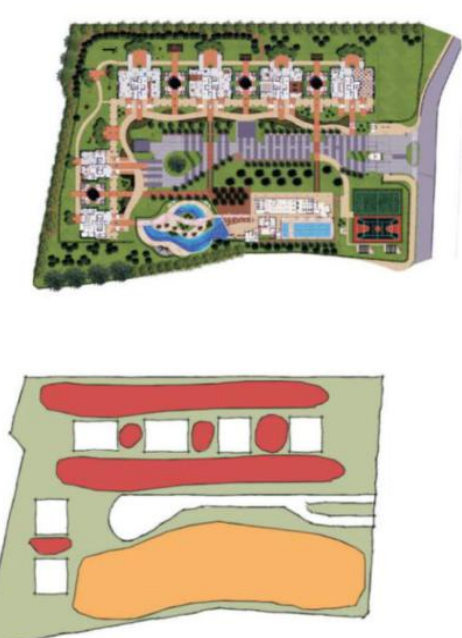

ÁREA : $43.700 \mathrm{~m}^{2}$

T.0.:0,1

C.A.: aprox. 2
VILA NOVO LEOPOLDINA (2008)
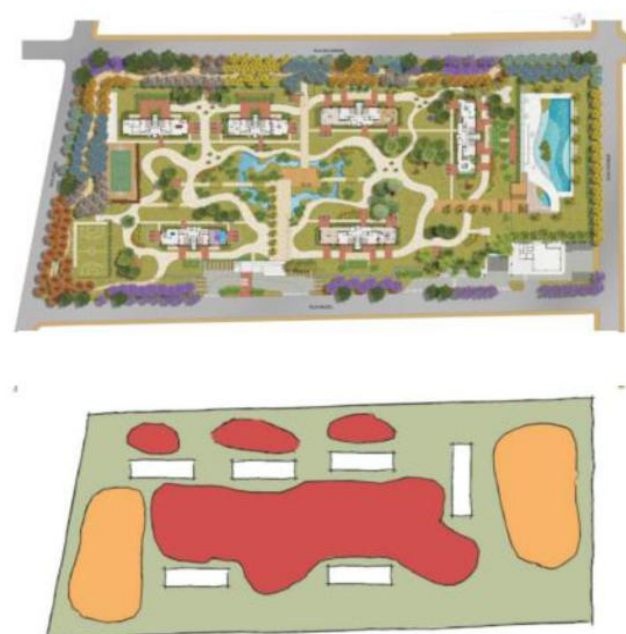

\section{ÁREA : $12.200 \mathrm{M}^{2}$}

T.0.: 0,08

C.A.: aprox. 2.5

ELABORAÇÃO: Autor - com base nas ilustrações realizadas por Guilherme Gabriel Alves. (ALVES, 2010)

CIRCULAÇÃO

ÁREAS ARBORIZADAS

EQUIPAMENTOS DE LAZER 


\section{A QUALIFICAÇÃO DOS ESPAÇOS LIVRES}

Em São Bernardo do Campo, a Lei no 5716/07 define que (art. 42) "os empreendimentos condominiais residenciais ou mistos implantados em terrenos com área de terreno igual ou superior a $10.000 \mathrm{~m}^{2}(\ldots)$ [deverão contemplar] reserva de área destinada ao lazer e recreação exclusiva dos condôminos, correspondente a 5\% (cinco por cento) da área total do empreendimento;".

Em Guarulhos, a Lei № 6253/2007, que regulamenta o Plano Diretor de Desenvolvimento Urbano, Econômico e Social do Município de Guarulhos (Lei no 6.055, de 30 de dezembro de 2004, define que (Art. 55): "A implantação de conjunto residencial vertical [R4]deverá obedecer as disposições da zona de uso na qual se localizar, além de [destinar], 10\% (dez por cento) da área total do lote ou gleba para uso comum do condomínio, sendo no mínimo 5\% (cinco por cento) para área verde e os demais 5\% (cinco por cento) para outras atividades;"

Estas exigências são mais incisivas no Município de São Paulo. A legislação separa os condomínios residências verticais em duas categorias (Art. 7 e 8, Decreto no 45.817/05): aqueles "com área de terreno ou terrenos inferior a $20.000 \mathrm{~m}^{2}$ (vinte mil metros quadrados) ou aquele com até 400 (quatrocentas) unidades habitacionais" e aqueles "com área de terreno ou terrenos superior a $20.000 \mathrm{~m}^{2}$ (vinte mil metros quadrados) ou aquele com mais de 400 (quatrocentas) unidades habitacionais", com exigências de espaços livres específicas para categoria, sintetizadas no QUADRO 6. 
QUADRO 7: EXIGÊNCIAS PARA A QUALIFICAÇÃO DOS ESPAÇOS EM CONDOMÍNIO PARA OS CONJUNTOS

RESIDENCIAIS VERTICAIS NO MSP (Lei no 45.817/05)

\begin{tabular}{|c|c|c|c|c|}
\hline CONJUNTO RESIDENCIAL VERTICAL: & ABAIXO DE DE & $0.000 \mathrm{M}^{2}$ OU 400 UHS. & ACIMA DE 20 & $\mathrm{OM}^{2}$ OU 400 UHS \\
\hline ÁREAS COMUNS (ART.7 E 8) & DESCOBERTAS & COBERTAS ou não & DESCOBERTAS & COBERTAS ou não \\
\hline ÁREAS VERDES, arborizadas e ajardinadas & & & $15 \mathrm{~m}^{2} / \mathrm{UH}$ & \\
\hline EQUIPAMENTOS DE USO COMUM (ART. 7) DE LAZER (ART.8) & $5 \mathrm{~m}^{2} / \mathrm{UH}$ & $3 \mathrm{~m}^{2} / \mathrm{UH}$ & $1 \mathrm{~m}^{2} / \mathrm{UH}$ & \\
\hline EQUIPAMENTOS COMUNITÁRIOS & & & & $2 \mathrm{~m}^{2} / \mathrm{UH}$ \\
\hline COMÉRCIO DE ABASTECIMENTO & & & & $4 \mathrm{~m}^{2} / \mathrm{UH}$ \\
\hline RESERVA ÁREAS INSTITUCIONAIS & & & & $4 \mathrm{~m}^{2} / \mathrm{UH}$ \\
\hline
\end{tabular}

ELABORAÇÃO: Autor. FONTE: Base EMBRAESP

Segundo esta lei, um empreendimento R2V de 300 UHs (coluna 2), será necessário a destinação de $1.500 \mathrm{~m}^{2}$ de área descoberta para equipamentos de lazer e $900 \mathrm{~m}^{2}$ de área coberta de equipamentos comunitários (destacando-se que a definição dos termos "equipamentos de lazer" e "equipamentos comunitários" não é clara na lei). Curiosamente, para empreendimentos com área de lote acima de $20.000 m^{2}$ ou 400 UHs, em referência à extinta subcategoria R3-02, presente nas Leis no 8.881/79, n은 8.001/73 e no 7.805/72, as exigências são ainda maiores. O expediente aprobatório abrange "o plano de distribuição interna para parcelamento do solo, nos termos do disposto nos artigos 3o e 6o da Lei no 9.413/1981", onde é exigida uma série de áreas de uso comum, referenciando as áreas de uso público dos loteamentos. 
Coube, inclusive, ao PARSOLO (departamento responsável pelo controle do parcelamento do solo) e não ao APROV (departamento de aprovação de projetos) estabelecer diretrizes, analisar a implantação e aceitar, tecnicamente, a infraestrutura destes conjuntos residenciais. Ao exigir a destinação das áreas de uso em condomínio, com base naquelas exigidas no processo de loteamento (áreas institucionais e comércio de abastecimento), a lei paulistana assume que a aprovação de empreendimentos acima do porte especificado não pode ser tratada como um conjunto residencial vertical convencional, mas configuram “condomínios com características de loteamento”, nas palavras da Arq. Maria Lucia Tanabe, refletindo um conflito no modo como estes supercondomínios são entendidos na legislação edilícia paulistana.

\section{A LEGISLAÇÃO AMBIENTAL}

Também contribuindo para ampla oferta de espaços de uso comum nos supercondomínios, estão as leis ambientais. Esta análise focou no Código Florestal, devido à evidência das Áreas de Preservação Permanente (APPs) nesta dinâmica.

A Constituição da Republica de 1988 determina que preservar as florestas, a fauna e a flora, são de competência comum da União, dos Estados, do Distrito Federal e dos Municípios. Legislar sobre florestas e o meio ambiente é tarefa da União, dos Estados, do Distrito Federal (Art. 24 CF), limitando a União ao estabelecimento de normas gerais. No âmbito federal, a regulamentação do uso e ocupação nas áreas de "floresta" é matéria do Código Florestal (Lei no 4.771/6577). Segundo o Código “As florestas

${ }^{77}$ A Lei no 4.771/65 foi revogada pela Lei no 12.727/ 2012. Como este trabalho concentra-se na produção realizada entre 20012010, análise se baseará na lei anterior. Entretanto, a nova lei não trouxe alterações significativas nos pontos aqui discutidos. 
existentes no território nacional e as demais formas de vegetação, reconhecidas de utilidade às terras que revestem, são bens de interesse comum a todos os habitantes do País, exercendo-se os direitos de

propriedade, com as limitações que a legislação em geral e especialmente esta Lei estabelecem." (Art. 1,

grifo nosso).

Para isso o código define a Área de Preservação Permanente (APP): "área protegida [...]coberta ou não por vegetação nativa, com a função ambiental de preservar os recursos hídricos, a paisagem, a estabilidade geológica, a biodiversidade, o fluxo gênico de fauna e flora, proteger o solo e assegurar o bem-estar das populações humanas". Ainda que a lei preveja exceções (Art. 4), na prática as APPs são áreas destinadas exclusivamente à proteção de suas funções ecológicas (FERREIRA, 2007. P.240).

Art. $2^{\circ}$ Consideram-se de preservação permanente, pelo só efeito desta Lei, as florestas e demais formas de vegetação natural situadas:

a) ao longo dos rios ou de qualquer curso d'água desde o seu nível mais alto em faixa marginal cuja largura mínima será: (Redação dada pela Lei no 7.803 de 18.7.1989)

1 - de 30 (trinta) metros para os cursos d'água de menos de 10 (dez) metros de largura; (Redação dada pela Lei n⿳⺈ 7.803 de 18.7.1989)

2 - de 50 (cinquenta) metros para os cursos d'água que tenham de 10 (dez) a 50 (cinquenta) metros de largura; (Redação dada pela Lei no 7.803 de 18.7.1989)

3 - de 100 (cem) metros para os cursos d'água que tenham de 50 (cinquenta) a 200 (duzentos) metros de largura; (Redação dada pela Lei no 7.803 de 18.7.1989)

4 - de 200 (duzentos) metros para os cursos d'água que tenham de 200 (duzentos) a 600 (seiscentos) metros de largura; (Redação dada pela Lei no 7.803 de 18.7.1989)

5 - de 500 (quinhentos) metros para os cursos d'água que tenham largura superior a 600 (seiscentos) metros; (Incluído pela Lei no 7.803 de 18.7.1989)

b) ao redor das lagoas, lagos ou reservatórios d'água naturais ou artificiais;

c) nas nascentes, ainda que intermitentes e nos chamados "olhos d'água", qualquer que seja a sua situação topográfica, num raio mínimo de 50 (cinquenta) metros de largura; (Redação dada pela Lei no 7.803 de 18.7.1989) 
d) no topo de morros, montes, montanhas e serras;

e) nas encostas ou partes destas, com declividade superior a $45^{\circ}$, equivalente a $100 \%$ na linha de maior declive

f) nas restingas, como fixadoras de dunas ou estabilizadoras de mangues;

g) nas bordas dos tabuleiros ou chapadas, a partir da linha de ruptura do relevo, em faixa nunca inferior a 100

(cem) metros em projeções horizontais; (Redação dada pela Lei no 7.803 de 18.7.1989)

h) em altitude superior a 1.800 (mil e oitocentos) metros, qualquer que seja a vegetação. (Redação dada pela Lei no 7.803 de 18.7.1989)

i) nas áreas metropolitanas definidas em lei. (Incluído pela Lei no 6.535, de 1978) (Vide Lei no 7.803 de 18.7.1989)

Parágrafo único. No caso de áreas urbanas, assim entendidas as compreendidas nos perímetros urbanos definidos por lei municipal, e nas regiões metropolitanas e aglomerações urbanas, em todo o território abrangido, obervar-se-á o disposto nos respectivos planos diretores e leis de uso do solo, respeitados os princípios e limites a que se refere este artigo.

Com a alteração do perímetro de atuação e o foco nos segmentos de padrão médio e econômico, a presença das APPs nos lotes disponíveis se tornou cada vez mais frequente. A corrida pela montagem dos landbanks também reduziu as possibilidade de opção, restando aqueles que nem sempre apresentavam as características ideais. Ainda que apresentassem um transtorno a ser superado, a existência de APP não significava a inviabilidade financeira. Apesar do uso restrito, o potencial constritivo referente a parte do lote em APP pode ser utilizado na parte do lote que esta fora da APP e os custos decorrentes das limitações são abatidos pelo mercado, fazendo que estes terrenos tenham preços reduzidos quando comparados àqueles em igual localização.

A existência de pequenos córregos a céu aberto, nos fundos ou ladeando estes terrenos tornouse comum, e com isso os parques ao longo destes. Com 30 metros de largura para cada lado, para cursos d'água de menos de até 10 metros de largura, as áreas de APP passaram a integrar o programa de espaços de lazer nestes condomínios - mesmo que de lazer contemplativo, dadas às restrições legais de edificação nestas áreas. O mesmo ocorreu a respeito das exigências de manutenção de maciços arbóreos, 
e compensação ambiental. Ao analisar os projetos dos espaços livres oferecidos nos supercondomínios, constatou-se que a "melhor qualidade de vida presente" na ideologia da "nova forma de morar", quando associada a uma maior "proximidade da natureza", se revelou menos uma escolha gratuita do incorporador, mas, frequentemente, uma obrigação devido às exigências legais de preservação e recuperação em áreas de Preservação Permanente.

ILUSTRAÇÃO 5: O USO RECREATIVO DAS APPS NOS CONDOMÍNIOS RESIDENCIAS VERTICAIS.

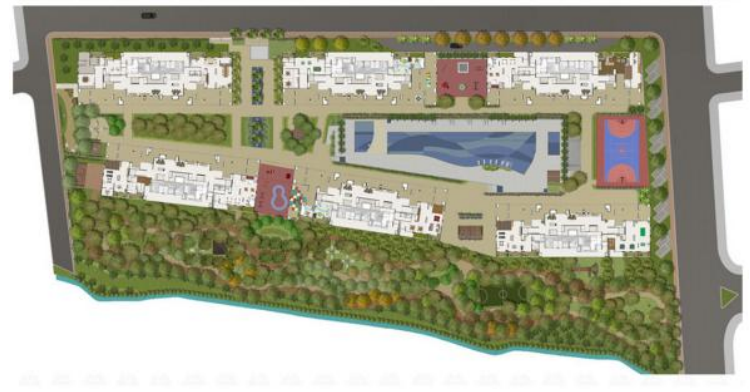

COND. ALEGRIA (2008) - GUARULHOS

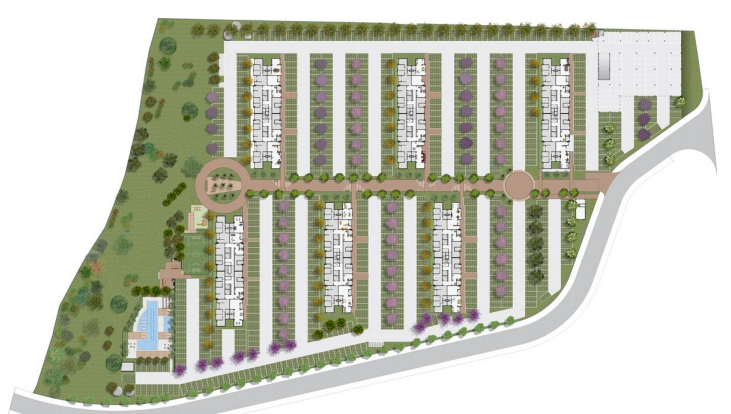

COND. FATTO SPORT FARIA LIMA (2009) - GUARULHOS ELABORAÇÃO: Autor.
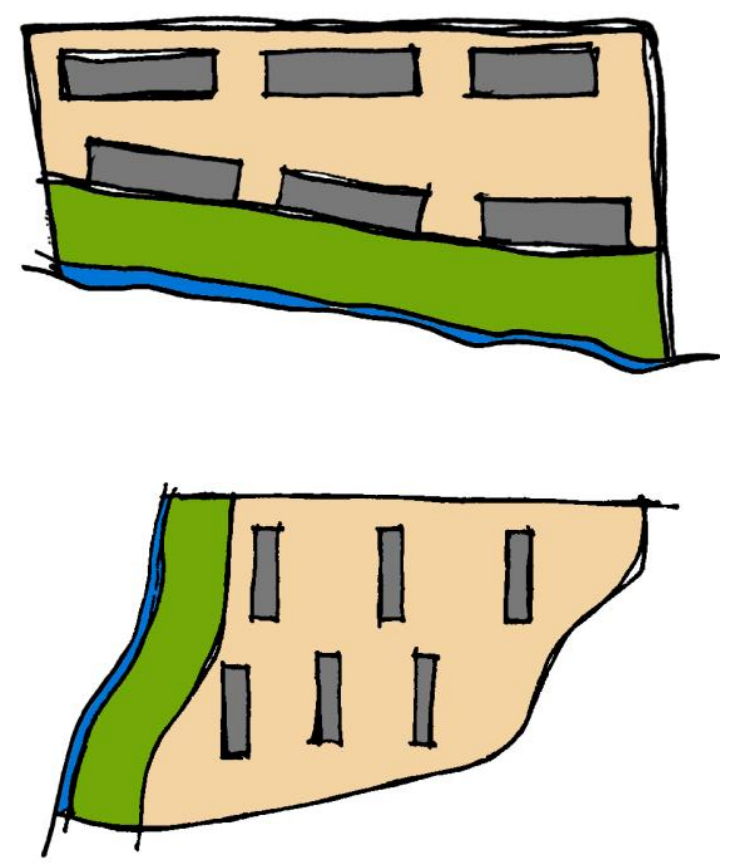

ÁREA DE APP

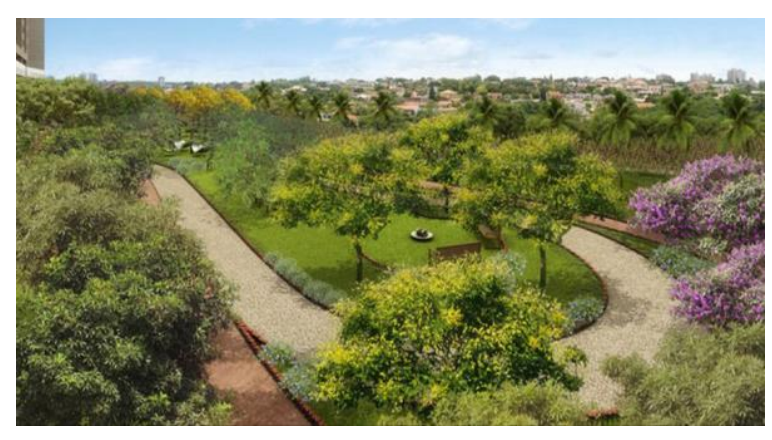

PERSPECTIVA APP

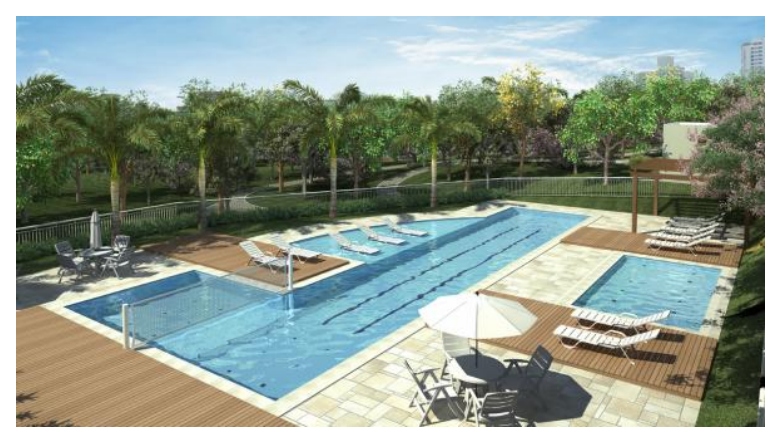

PERSPECTIVA PISCINA - APP AO FUNDO 
A ilustração 05 apresenta dois empreendimentos localizados em Guarulhos que, com parte do lote em APP, criaram bosques privativos ao longo dos corpos d'água. O Alegria (2008), realizado pela Incorporadora Gafisa, atende o segmento de padrão médio, totaliza 834 apartamentos em seis torres. A área de preservação que margeia o empreendimento serviu de mote para a campanha: "mais de 15mil $\mathrm{m}^{2}$ de terreno com estrutura completa e uma área de lazer dentro de um bosque privativo com mais de $6 \mathrm{mil} \mathrm{m}^{2}$ para você e sua família aproveitarem cada minuto ao lado da natureza"78. O Fatto Sport Faria Lima (2010), realizado pela Incorporadora Plano e Plano, totaliza 900 apartamentos em seis torres e foi comercializado dentro do programa habitacional do Governo Federal, PMCMV. Com vagas de carro ao tempo e sistema viário ocupando quase que todos os espaços livres (característica comum dos empreendimentos econômicos), a área de lazer, de pequenas proporções, foi estrategicamente localizada no fundo do terreno, integrando-a com a APP, que serve de "fundo" para as imagens dos equipamentos em condomínio. Em ambos os casos, a propaganda não leva em consideração o fato de que estas APPS urbanas se encontravam degradadas e precariamente arborizadas. Mesmo que a recuperação da vegetação estabelecida por lei seja um compromisso assumido pelo incorporador, tardará muitos anos para que a regeneração da área concretize os parques e bosques representados nas perspectivas.

\footnotetext{
${ }^{78}$ Frase utilizada no Website da empresa e nos matérias distribuídos na rua.
} 


\section{A LEI E OS SUPERCONDOMÍNIOS}

O trabalho mostra que, a incorporação de lotes cada vez maiores, foi estratégia desenhada pelos promotores e ratificada pela lei, devido à ausência de limites máximos de lote incorporável, ao desestímulo do desmembramento, e ao estimulo do remembramento. Com lotes maiores, as T.O e C.A. vigentes resultaram na disponibilidade de grandes espaços livres de uso comum, em valores absolutos, nos térreos destes edifícios, permitindo a concretização de "amplos" programas de espaços de lazer, fato acentuado devido à falta de leis e normas que definissem critérios mínimos de dimensionamento e desempenho destes espaços.

Neste contexto, a "mercantificação" dos espaços em condomínio surge como saída obvia. Se a sua reserva (e aparelhamento) não é opcional e, devido às características únicas de cada terreno, exigem projetos 'personalizados' (em contraposição às torres e aos apartamentos que, sob a lógica do controle de custos, são repetidos até a exaustão), caberá ao promotor imobiliário, com o apoio de seus colaboradores, dar às exigências legais a aparência de soluções "sob medida", tomadas por livre opção das incorporadoras, para a satisfação das necessidades e desejos dos potenciais compradores oferecendo uma nova forma de morar - conferindo identidade e agregando valor ao empreendimento. Isto significa que, mesmo que as características de "clube" propriamente ditas não estejam presentes, substituídas por uma nova "tendência" mais atual, sob o ponto de vista da estrutura forma, a lógica imobiliária vigente durante o Boom imobiliário, enquadrada do marco relatório vigente, levará, por a realização de empreendimentos residenciais verticais, com ampla oferta de espaços livres em condomínio. 
A associação entre a produção dos supercondomínios e o marco regulatório edilício não se deu pelas mudanças ocorridas na legislação na última década - pouco significativas para a observação do fenômeno - mas é fruto da relação de um marco regulatório edilício pré-existente com um novo cenário sócio econômico. Ainda que não seja escopo discutir as justificativas originais de cada instrumento ou lei - investigação atraente, mas desnecessária para provar os seus desdobramentos na produção atual ficará evidente que, individualmente, instrumentos e leis se explicaram - e ainda se explicam - por razões outras que não fomentar a produção dos supercondomínios.

O modo como cada instrumento previsto em lei condiciona a produção imobiliária, inibindo, estimulando, ou coibindo, depende menos de características própria, que das relações que estabelece com os outros instrumentos e, principalmente, com a lógica vigente do capital incorporador. Esta "condução" leva a formação de tendências projetuais, a exemplo do supercondomínios. No caso dos fenômeno dos supercondomínios, o fator que parece ter sido subestimado pela legislação, do ponto de vista da orientação do desenho urbano, é a potencialização, para o bem e para o mal, da criação dos espaços livres conforme aumenta o porte do lote.

A respeito da Fórmula de Adiron, na legislação do MSP, Martins (2011) afirma que o instrumento favoreceu unicamente ao promotor imobiliário, pois permite um ganho de área construída sem uma contrapartida de interesse coletivo ou ambiental. Incentivaria a construção de uma infraestrutura de lazer diferenciada, sofisticando o empreendimento, mas não atrelaria, por exemplo, a redução da impermeabilização do subsolo, utilizado para a construção de garagens. "Esse padrão, associado a 
imagens produzidas pelo marketing imobiliário e à escalada da violência urbana, construiu um padrão de moradia que nega o espaço público, a urbanidade e a diversidade dos centros urbanos" $(2011$, p.70)

O fato é que a criação do incentivo, e de outros instrumentos que acabaram por limitar a ocupação do lote, esteve amparada em uma série de premissas "técnicas" que permearam a elaboração e a revisão das LUOS no MSP durante a década de 1970 e 1980. Segundos estes, a insalubridade das casas e apartamentos, atestada pela iluminação e ventilação naturais deficientes, poderia ser resolvida pela lei através da redução da T.O. e do C.A. Sob esta ideologia, a redução suplementar da T. O. melhoria ainda mais a salubridade dos apartamentos, e dos lotes vizinhos, justificando o "premio" da área construída adicional oferecida. Constatação que não atesta a validade do instrumento, mas a necessidade de se circunscrevê-lo dentro de toda uma legislação construída sobre parâmetros pouco discutidos e pouco avaliados. 


\section{CAPÍTULO 05 - NOTAS FINAIS}

\section{1 - CONCLUSÕES}

O trabalho desenvolvido mostra que o aumento de supercondomínios lançados na RMSP na década de 2000 é, enquanto fenômeno, um acontecimento novo no processo de verticalização da metrópole paulistana, que não pode ser explicado como consequência apenas do sucesso comercial de uma suposta "nova forma de morar".

A origem do fenômeno dos supercondomínios reside nas transformações ocorridas no mercado habitacional brasileiro ao longo da década de 2000, criando uma janela de oportunidade que determinou a reestruturação operacional dos promotores imobiliários e a revisão das estratégias de atuação, evidenciadas a partir do Boom imobiliário (2006).

Verificou-se que em um contexto de risco financeiro reduzido, com oferta de crédito e demanda disponível abundantes, promotores imobiliários alcançaram o ganho de escala priorizando o desenvolvimento de empreendimentos de maior receita (VGV), medida que, nos segmentos de padrão médio e econômico, resultou em conjuntos habitacionais com maior área de lote e número de apartamentos, explicando a concentração dos supercondomínios nestes segmentos de mercado.

Este movimento foi liderado pelas empresas incorporadoras com ações negociadas em pregão, capitalizadas por meio da emissão de ações durante o período do Boom. Estas mantiveram área média de 
lote incorporado significativamente maior que a média de mercado, garantindo que os empreendimentos 'econômicos' oferecessem maior eficiência operacional, ao proporcionar volumes de negócios semelhantes àqueles de alto padrão.

A orientação à produção acessível levou à revisão do perímetro de atuação, englobando territórios característicos de classe média e baixa renda - necessidade motivada também pelo esgotamento dos lotes livres dos tradicionais territórios da elite.

Do ponto de vista da metrópole paulistana, observou-se a orientação do mercado para os municípios vizinhos da capital (RMSP-MSP), que entre 2006-2010 passaram a responder por 40\% do total de UHs lançadas na RMSP, contra 21\%, entre 2001-2005, com destaque para o município de Guarulhos. Juntos, mantiveram porte físico de empreendimentos significativamente maiores que a capital, o que fez com que nestes, o fenômeno dos supercondomínios se apresentasse, proporcionalmente, em maior intensidade.

No MSP, localidades vistas como de classe média pelo mercado até a década de 1990, a exemplo de Tatuapé, Itaim e Perdizes, tornaram-se o novo destino da classe média alta e estabeleceram-se como centro dos novos vetores de atuação do mercado. Intensificou-se a atividade ao longo do eixo do Rio Pinheiros e em distritos de baixa renda na Zona Leste e Zona Oeste.

A espacialização dos dados mostrou que o fenômeno dos supercondomínios está calcado na reprodução do solo urbano, ao contrário do fenômeno dos loteamentos fechados, ou 'condomínios fechados', característico da década de 1980. Situação observada tanto na capital como nas cidades vizinhas. 
Os supercondomínios surgiram em áreas já loteadas e dotadas de boa infraestrutura (questão central da discussão do fenômeno). A disponibilidade de grandes lotes nestas foi fundamental para o redesenho da estratégia de atuação dos promotores imobiliários. Assim, a procura pelos antigos distritos industriais e de galpões, como Barra Funda, Lapa, Vila Leopoldina e Jaguaré e Rio Pequeno na Zona Oeste, Mooca e Belém, no Centro e Santo Amaro e Campo Grande na Zona Sul da capital e pelos municípios de Guarulhos e $A B C$, em geral, é parte importante deste fenômeno, sediando a maior parte dos supercondomínios lançados na RMSP.

Os dados sugerem também que o fenômeno levou à redução dos vazios urbanos metropolitanos. A corrida para a montagem dos landbanks durante o boom imobiliário, fez com que os lotes ociosos ou subutilizados, mas bem localizados, alcançassem valores exorbitantes, levando à venda e à sua edificação, após décadas de especulação - relação que carece de um estudo mais detalhado.

\section{O PARADOXO DO OÁSIS URBANO}

O destaque dado aos espaços em condomínio, característica mais emblemática desta produção recente, esteve diretamente relacionado ao aumento do porte dos empreendimentos, em tamanho do lote e número de apartamentos. Se por um lado, em números absolutos, estes espaços são abundantes nos supercondomínios, por outro, considerando a proporcionalidade pelo número de apartamentos, não

há, necessariamente, uma maior oferta nestes quando comparados aos empreendimentos ditos 'convencionais'. 
A adoção de programas de lazer mais extensos, qualificando empreendimentos como 'parques', 'clubes' e 'vilas', explicou-se por duas outras razões: (i) lotes maiores potencializaram o aproveitamento dos espaços livres nos térreos dos edifícios, ao concentrá-los e diminuir a quantidade de espaços residuais, comportando, por exemplo, o uso vegetação de maior porte e (ii) a ausência de critérios de dimensionamento dos espaços em condomínio, em relação ao total de moradores previsto, possibilitou que em lotes maiores as opções de lazer crescessem em número - foco do argumento de vendas - e não em porte, prática que revelou o subdimensionamento dos equipamentos como uma característica recorrente nestes empreendimentos.

\section{LEI E A FORMA URBANA}

A avaliação do marco regulatório edilício sob a ótica da nova lógica financeira que pautou a atuação dos promotores imobiliários durante o Boom mostrou que, em conjunto, os parâmetros edilícios vigentes incentivaram a multiplicação dos supercondomínios. Destacaram-se as seguintes razões:

- Ao não restringir área máxima de lote incorporável e o número máximo de unidades por condomínios, desestimular o parcelamento, e estimular o remembramento de lotes, ratificou a estratégia de ganho de eficiência operacional por meio do aumento indefinido do porte físico dos empreendimentos, planejada pelos promotores imobiliários;

- Ao estabelecer índices de T.O. e C.A. independentes do porte físico do lote, a lei ignora o efeito potencializador destes, na produção de espaços livres, a medida que a área do lote aumenta. Se por um lado, os grandes lotes permitiram a realização de grandes torres verticais, ao gosto da eficiência construtiva, por outro, as baixas taxas de ocupação resultantes da aplicação da lei 
levaram à formação de grandes espaços não ocupados no térreo dos edifícios - que, enquanto negócio imobiliário, podem ser lidos como colateral (ou resíduo) próprio da operação que envolve a produção da habitação vertical.

- Ao definir exigências mínimas de áreas ajardinadas, equipamentos de lazer cobertos e descobertos em condomínio - e em proporções ainda maiores, em lotes maiores, a exemplo da legislação paulista (R2V) - sem estabelecer critérios para o dimensionamento dos equipamentos de uso comum e para assegurar as condições de salubridade dos espaços livres, a lei admitiu que os mesmos fossem utilizados como argumento de vendas, sem a garantia de que fossem satisfeitas as condições mínimas necessárias para o uso previsto.

- Ao condicionar a edificação do lote à recuperação e à conservação de áreas de preservação, e dada à recorrência destas no novo perímetro de atuação do mercado imobiliário, a legislação favoreceu a formação de áreas verdes privadas, sagazmente trabalhadas como bosques e parques privativos. 


\section{2 - DESDOBRAMENTOS}

A discussão de temas relacionados aos supercondomínios inevitavelmente levanta uma expectativa de posicionamento a favor ou contra a sua produção: este não é o caso. Justamente por acreditar que a mudança de cenário foi tamanha e que os argumentos antes levantados podem já não ser apropriados, assumiu-se como objetivo deste trabalho apresentar este novo cenário e organizar dados para instigar uma nova discussão. Arrisco-me aqui a propor um encaminhamento, entre os vários que as constatações levantadas sugerem, com foco no marco regulatório edilício, dado o seu protagonismo no fenômeno estudado.

Segundo os resultados alcançados, a lei exerceu um papel importante, para o estabelecimento do fenômeno dos supercondomínios. Ao ponto que uma simples mudança de diretriz na política urbana, federal ou local, - por exemplo, definindo o tamanho do lote máximo incorporável (uma vez que define o mínimo!)- seria suficiente para por fim a produção de novos supercondomínios. Contudo, identificar a ideologia presente na lei que justificaria o incentivo oferecido à produção dos supercondomínios parece ser a chave para compreender quais deficiências a lei procurou atender. Se a pergunta que orientou o desenvolvimento deste trabalho foi: porque ocorreu o aumento dos supercondomínios ao longo da década de 2000, a pergunta que segue é, qual a justificativa do incentivo exercido pela lei a este modelo de empreendimento?

Na cidade de São Paulo, os parâmetros de uso e ocupação vigentes em 2013 praticamente repetem as mesmas exigências da lei de 1972, quando a realização dos supercondomínios era exceção à regra e o aumento de sua produção, 30 anos depois, imprevisível. O incentivo exercido dependeu mais 
de uma relação que se estabeleceu entre a lei e um contexto socioeconômico favorável, uma conjuntura de mercado mais "moderno" e "eficiente", do que por uma intenção própria da lei quando foi concebida. Dito isto, no MSP, a Lei de 1972 e, posteriormente, a Lei de 2002, consentiu a realização dos supercondomínios e estabeleceu critérios para qualificá-los. A aprovação destes exigiu, em contrapartida, infraestrutura diferenciada de lazer e serviços interna ao condomínio (subcategoria R03, posteriormente substituída pela nomenclatura R2V).

Maria Lucia Tanabe, arquiteta da Secretaria de Habitação (SEHAB) da Prefeitura de São Paulo, que em 2002 participou ativamente da revisão da LUOS, quando era diretora do PARSOLOS, justificou o tratamento diferenciado dado a estes conjuntos habitacionais uma vez que estes constituíam "condomínios com características de loteamento" - recaindo assim em exigências semelhantes ao loteamento - revelando-se um conflito:

O processo de qualificação do território no processo de urbanização se dá em duas etapas. Na primeira, a etapa de parcelamento do solo, a qualificação se dá por meio da doação compulsória de áreas para a criação do sistema de espaços públicos, garantindo assim a provisão de equipamento públicos à demanda criada, e a conexão desta nova área ao tecido urbano consolidado, através da continuidade do sistema viário. Na segunda etapa, as leis de uso e ocupação do solo qualificam o espaço urbano ao regular a propriedade privada: são definidas Taxa de Ocupação (T.O.) e Coeficiente de Aproveitamento (C.A.), a fim de garantir condições de salubridade adequadas internas ao lote. Legalmente, condomínios não rivalizam com loteamentos, mas os sucedem: loteamento são forma de parcelamento e os condomínios não. Ao assumir que lotes urbanos (fruto de loteamentos) quando incorporados possuem 
características de loteamento, admite-se que o processo de parcelamento precedente foi insuficiente ou deficiente.

É fato que na cidade de São Paulo e também em cidades vizinhas a falta de planejamento nos estágios iniciais de urbanização gerou um passivo urbano difícil de ser superado. Antes mesmo que a lei federal no 6766/79 entrasse em vigência, exigindo a doação de 35\% da área no processo de parcelamento, o traçado viário e o sistema de áreas públicas já estavam definidos nos principais bairros da cidade, frequentemente em quantidade e qualidade insuficientes. Fato agravado pelo adensamento e mudanças de usos em zonas específicas da cidade e pela ocupação irregular das áreas livres existentes.

No parcelamento de bairros industriais, por exemplo, permitiu-se a redução das doações de áreas públicas, em razão do uso a que se destinavam. Com a decadência da atividade industrial e o crescimento da demanda habitacional, estes bairros, com disponibilidade de grandes lotes desocupados, propícios à realização de supercondomínios, tornaram-se estratégicos e definiram novos vetores de expansão da atividade imobiliária, sem que para isso fosse suplementado o sistema de áreas públicas existente, compatível com o novo uso residencial proposto. Isto é, não foram contemplados instrumentos para viabilizar uma doação complementar, medida justificável também pela valorização dos terrenos face a permissão do uso residencial. Na Vila Leopoldina, em São Paulo, galpões e fábricas ociosas deram lugar a dezenas de supercondomínios apesar da ausência de praças ou espaços necessários para a implantação de escolas públicas e postos de saúde que atendessem a nova demanda da região.

Estudos realizados no início da década de 90, pela Secretaria Municipal de Planejamento do Município de São Paulo (SEMPLA), (TAKIYA, 2002, p.10) indicaram que para a zona urbana, de um total de 
$31,3 \mathrm{~km}^{2}$ de áreas efetivamente doadas para áreas verdes, cerca de $10,6 \mathrm{~km}^{2}$ eram efetivamente ocupados por praças, canteiros, etc. Do restante, $5 \mathrm{~km}^{2}$ encontram-se vazios e $15,7 \mathrm{~km}^{2}$ foram ocupados por outros usos, sendo $10 \mathrm{~km}^{2}$ por favelas.

A relação de complementaridade entre parcelamento e ocupação do lote na qualificação do território é uma hipótese que encontra suporte na análise dos conjuntos habitacionais referenciados por arquitetos e urbanistas como "melhores práticas". Edifícios emblemáticos como o Copan e o Conjunto Nacional, na cidade de São Paulo, têm áreas em condomínio diminutas; T.O. elevadas, aproximadamente $45 \%$ e $100 \%$ respectivamente; e o C.A. muito superiores aos hoje permitidos no MSP, aprox. 20 e 12. Isto é, estão longe de atender, no que diz respeito à ocupação do lote, os padrões urbanísticos vigentes na lei, que supostamente garantiriam padrões mínimos de habitabilidade. Entretanto o que parece compensar as áreas comuns reduzidas e qualificá-los positivamente é a relação que estabelecem com os outros lotes vizinhos: cercados por espaços públicos e privados, comerciais e institucionais, que convidam ao convívio social.

Para aquele que se debruça sobre o tema, a requalificação do espaço urbano é um problema sem solução ideal aparente. Os lotes existentes derivam de loteamento que já contribuíram, precariamente ou não, com suas parcelas de áreas doadas. A possibilidade do reloteamento, ainda que referida na Lei federal no 6766/79 (art. 44)), é pouco conhecida, provavelmente pelos gigantescos entraves políticos e custos envolvidos que o processo de expropriação exigiria. As operações urbanas consorciadas, ainda que controversas, são uma alternativa e talvez por isso tenham se tornado instrumento tão popular entre 
arquitetos urbanistas. Mas a sua concretização depende do interesse de promotores imobiliários em investir maciçamente em uma única área, limitando a sua abrangência a bairros específicos das cidades.

Neste contexto, as exigências relativas aos espaços livres nos condomínios parecem justificar-se no desafio apresentado pela necessidade de requalificação do território: compensam com rigor na regulamentação de uso e ocupação (espaços privado) as carências decorrentes da falta de rigor no processo de parcelamento do solo (espaço público). Independentemente de substituírem ou não a experiência do espaço público, os supercondomínios acabam por oferecer aos seus moradores, e apenas a estes, cenários para a promoção do convívio social.

\section{UM INSTRUMENTO ALTERNATIVO}

A análise do marco regulatório edilício, sob a lógica do promotor imobiliário, oferece uma solução alternativa para uso do mercado imobiliário, enquanto ativo público, e dos promotores imobiliários, enquanto instrumento de mobilização deste ativo, para a requalificação dos espaços urbanos, que não através do estímulo à produção dos supercondomínios: a doação compulsória premiada.

Se a ocupação de lotes de porte elevado configura "condomínios com características de loteamento", justificativa para contrapartidas específicas da lei paulistana, uma proposta seria utilizá-los para a produção de espaços públicos. Exigir a doação compulsória de áreas públicas para lotes com área superior a, por exemplo, $10.000 \mathrm{~m}^{2}$, poderia ser uma maneira de corrigir as distorções que os grandes lotes geram no tecido urbano. 
Para o promotor imobiliário, a doação compulsória levaria, a princípio, à perda do potencial construtivo referente à área doada, como ocorre no loteamento ou quando há a desapropriação. Se isso ocorrer, as possibilidades de se por em prática este instrumento seriam reduzidas, por comprometer o valor do terreno (e assim, os interesses dos seus proprietários). Este entrave poderia ser resolvido se, ao invés de levar à perda do potencial construtivo, a doação destinasse este potencial à área remanescente, transformando a doação em um benefício para o proprietário do terreno.

ILUSTRAÇÃO 6: ESTUDO INSTRUMENTO URBANÍSTICO: “DOAÇÃO COMPULSÓRIA PREMIADA".

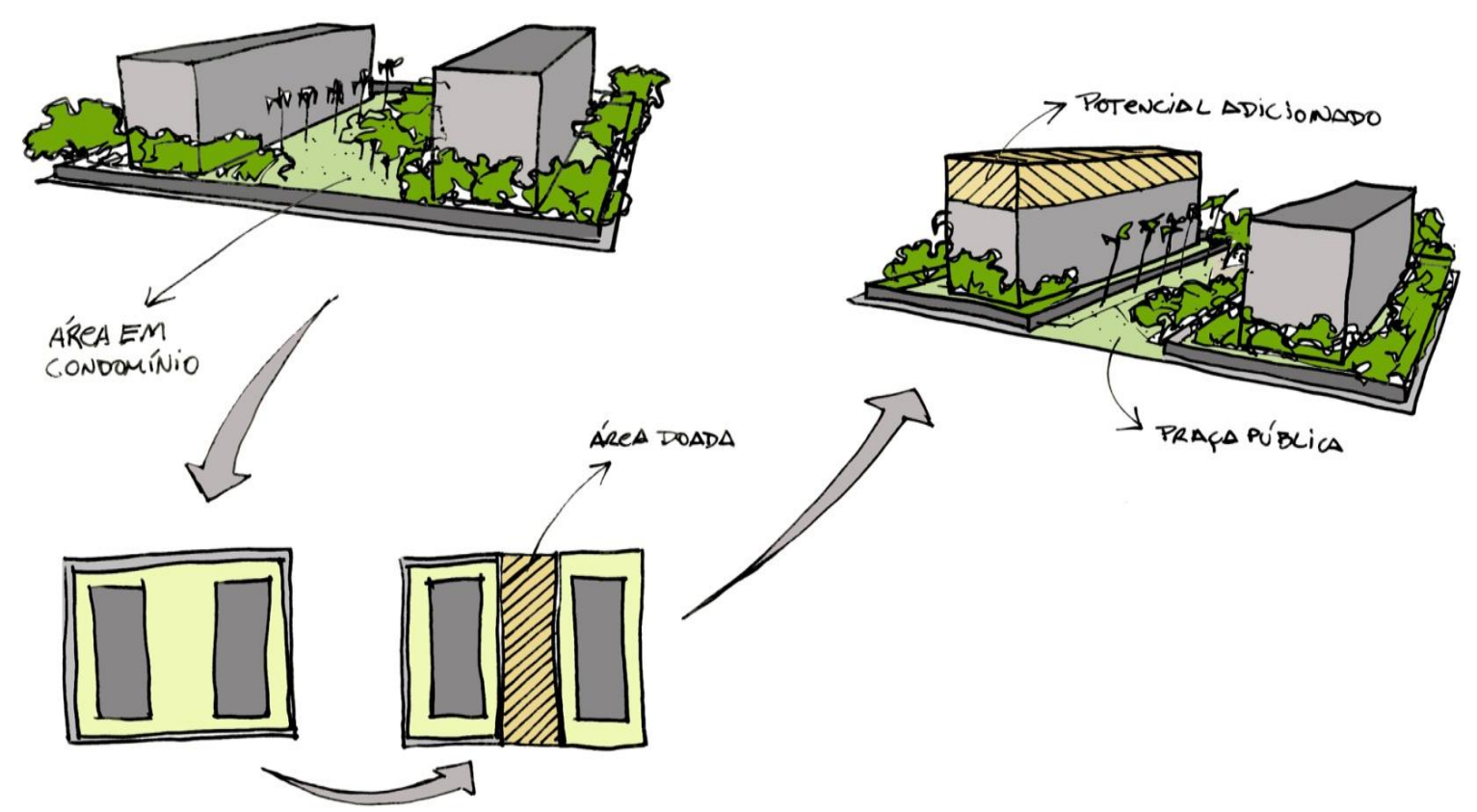

ELABORAÇÃO: Autor. FONTE: Base EMBRAESP 
Segundo a lógica econômica que orienta a atividade imobiliária, aumentar o potencial construtivo em áreas onde a oferta de terrenos é limitada e os custos da propriedade altos, apresenta grande atratividade ao permitir, por exemplo, que sejam produzidos mais apartamentos por lote. Provavelmente os benefícios em se alargar ruas e calçadas, ou criar praças, pequenos parques e novas ruas justifiquem o prêmio oferecido ao promotor e contribuiria enormemente para a maior permeabilidade, sob o ponto de vista da circulação urbana, um problema ressaltado na crítica que a academia faz aos supercondomínios. Mesmo os possíveis prejuízos em se permitir uma maior densidade construída final, decorrente do aumento do potencial construtivo, poderiam ser mitigados pela criação de um novo espaço público, trazendo mais benefícios à sociedade que a criação do mesmo espaço (praça, parque ou bosque) interno ao condomínio (ILUSTRAÇÃo 06).

Neste caso, a avaliação da área a ser doada, em quantidade e destinação - uma nova rua, um alargamento de calçada, bosque ou praça - caberia ao Município, em um processo de emissão de diretrizes equivalente àquele exigido ao parcelamento do solo (Lei 6766/79), responsável por garantir o interesse público na operação.

Como decorrência a medida reduziria o número de supercondomínios produzidos já, que como observado, estes tem relação direta ao porte dos lotes incorporados. No entanto este seria mais uma consequência indireta, já que o objetivo é a requalificação do sistema de espaços públicos. A princípio a medida poderia parecer pouco atrativa, pois comprometeria a oferta de grandes espaços em condomínio, e estes são o "objeto de desejo" da atualidade. Impasse que encontra, mais uma vez, resposta na afirmação de Villaça. A respeito do "capital produtor de moradias", o autor afirma que "em qualquer 
caso, ele desenvolve uma ideologia (a venda de um novo estilo de vida, mais moderno e seguro) em torno da 'nova' forma de morar." (VILLAÇA, 2005, p.184.)

\section{UM FENÔMENO AINDA POR CONHECER}

Quando propus o tema do aumento na produção dos supercondomínios, ainda não estava claro para mim a dimensão do fenômeno, que se mostrou maior do que eu imaginava.

Em 2012, os empreendimentos lançados alcançaram novos patamares de preços, reduzindo drasticamente o mercado consumidor. Com a desaceleração do mercado, a continuidade do fenômeno dos supercondomínios parece incerta. Se estes exigem grandes empresas (capazes de assumir o risco, mesmo que reduzido), e as grandes empresas se estruturaram baseada na abundância de capital e na demanda qualificada, o que ocorre quando esta retorna aos níveis anteriores ao Boom? Pode-se supor que as empresas voltarão a produzir empreendimentos com VGVs menores, que apresentem menor risco e atendam demandas mais pontuais e nichos de mercado, levando a redução da participação dos supercondomínios. Por outro lado, o porte que as empresas adquiriram nos últimos anos, e a necessidade de reprodução do capital que nelas foi investido, parece inviabilizar o retorno às pequenas empresas.

Todavia, o fenômeno está longe de poder ser compreendido em sua totalidade. Como é recente, as suas consequências ainda não podem ser observadas pela proximidade do fato. Com períodos de até três anos entre o lançamento (comercialização) e a entrega e ocupação das UHs, muitos dos empreendimentos estudados não foram sequer ocupados. Apesar do programa de espaços livres remeter 
a edifícios produzidos desde a década de 1950, o novo público, a nova localização, a escala da produção e o novo contexto econômico-financeiro, do qual faz parte a lógica imobiliária que orientou a expansão dos supercondomínios, são condições suficientes para que a crítica que se fez a este modelo de empreendimento no passado não possa ser utilizada para a crítica da produção recente, sem que se corra um grande risco. 


\section{REFERÊNCIAS}

ABRAHÃO, S. L. Espaço Público: do urbano ao político. São Paulo: Annablume: FAPESP, 2008.

ALIM, Pedro. IAPI: O seguro social; A indústria brasileira; O Instituto dos Industriários. Relatório do engenheiro Alim Pedro, presidente do IAPI no período, Rio de Janeiro, p.297.

ALVES, G. G. A configuração dos espaços livres nos grandes empreendimentos verticais da Grande São Paulo: As quadras- condomínio. Iniciação Científica. Orientador Silvio Soares Macedo. Faculdade de Arquitetura e Urbanismo da Universidade de São Paulo, São Paulo, 2010.

AMBROSIO, D. Construtoras já projetam crescimento maior este ano. Valor Econômico, 26 de Março de 2009. Disponível em: <http://oglobo.globo.com/economia/construtoras-ja-projetam-crescimento-maior-esteano-3133977>. Acesso em: 5 maio 2011.

AMBROSIO, D. Investidores estão de olho no caixa das construtoras. Valor Econômico, 18 de maio de 2011. Disponível em: <http://www.valor.com.br/ arquivo/ 888123/investidores-estao-de-olho-no-caixa-dasconstrutoras>. Acesso em: 5 maio 2011.

ANDRADE, L. T. de. Estilos de vida nos condomínios residências fechados. In: FRUGOLI, H. JR. \& ANDRADE, L. T. de \& PEIXOTO (org.). As cidades e seus agentes: práticas e representações. Belo Horizonte. Pucminas: EDUSP, 2006.

ANGEL, S. \& MAYO, S. Housing: enabling markets to work. Washington D.C.: The World Bank, 1993.

ARAGÃO, S. M. L. Espaços livres urbanos: a produção da caracterização das áreas de uso comum dos conjuntos de edifícios de apartamentos paulistanos (1990-2004). 2005. Tese (Doutorado) Faculdade de Arquitetura e Urbanismo da Universidade de São Paulo, São Paulo, 2005.

ARANTES, A. A. Paisagens paulistas: transformações do espaço público. Campinas: Imprensa Oficial: Editor Unicamp, 2000. 
BOECHAT, Y. Construtoras lançam R\$ 25 bi em imóveis. Valor Econômico, 28 de Março de 2008. Disponível em: <http://www.fazenda.gov.br/resenhaeletronica/MostraMateria.asp?cod=450696>. Acesso em: 25 de Fevereiro de 2013.

BONDUKI, N. Política habitacional e inclusão social no Brasil: revisão histórica e novas perspectivas no governo Lula. Universidade São Judas Tadeu. Mestrado em Arquitetura e Urbanismo: Revista eletrônica de Arquitetura e Urbanismo, $\mathrm{n}$-1, 2008. Disponível em: <http://www.usjt.br/arq.urb/numero _01/artigo_05_180908.pdf>. Acesso em 30 ago. 2012.

BONDUKI, Nabil. Origens da habitação social no Brasil: arquitetura moderna, lei do inquilinato e difusão da casa própria. 4. Ed. São Paulo: Estação Liberdade, 2004.

BORGES, A. Construção civil terá novo programa para treinar mão de obra. Valor Econômico, 27 Abril 2011.

Disponível em: <http://www.valoronline.com.br/impresso/especial/101/417921/construcao-civil-teranovo-programa-para-treinar-mao-de-obra>. Acesso em: 5 maio 2011.

BNDES - COUTINHO, L. M. Crédito Habitacional Acelera Investimento Residencial no País. Brasilia: no 18, 2006.

BRUNA, P. J. V. Os primeiros arquitetos modernos: habitação social no Brasil, 1930-1950. São Paulo: Edusp, 2010.

CALDEIRA, T. P. do Rio. Cidade de muros: crime, segregação e cidadania em São Paulo. São Paulo: Editora 34/Edusp, 2008.

CASTELO, A. M. et al. O Crédito Imobiliário no Brasil: Caracterização e Desafios. São Paulo: FGV projetos, 2007.

CATRO. F: Ibope corrige: 19\% da Classe C planeja comprar uma casa. Agência Estado, 6 de outubro 2010. Disponível em: <http://economia.estadao.com.br/noticias/not_37890.htm>. Acesso em: 5 maio 2011.

CHURCHILL Jr., G. A. \& PETER, J. P. Marketing: criando valor para os clientes. São Paulo: Saraiva, 2000.

DE MARCHI, P. M. Cidades em transição. Urbano em translação: o reuso de áreas industriais como metáfora da condição global. 2007. Tese (Doutorado) - Faculdade de Arquitetura e Urbanismo, Universidade de São Paulo, São Paulo, 2007.

D’ERCOLE, R. Brasil é o mercado de imóveis da vez. O Globo, 30 de outubro de 2006. Disponível em: <http://www.zap.com.br/revista/imoveis/fechando-negocios/brasil-e-o-mercado-de-imoveis-da-vez20061030/>. Acesso em: 25 de Fevereiro de 2013. 
D'OtTAVIANO, M. C. L. Condomínios fechados na Região Metropolitana de São Paulo: fim do modelo centro rico versus periferia pobre? 2008. Tese (doutorado)- Faculdade de Arquitetura e Urbanismo, Universidade de São Paulo, São Paulo, 2008.

EMBRAESP. Informativo imobiliário EMBRAESP. Caderno Residencial: 2001-2010. Empreendimentos residenciais lançados na região metropolitana de São Paulo.

ESPOSITO, M. Encol tenta acordo para terminar prédios. Folha de São Paulo, 24 de Maio de 1997. Disponível em: <http://www1.folha.uol.com.br/fsp/1997/5/24/dinheiro/8.html>. Acesso em: 25 de Fevereiro de 2013.

FELDMAN, S. Planejamento e zoneamento. São Paulo: 1947-1972. São Paulo: Edusp: FAPESP, 2005.

FERRAZ, G.. Warchavchik e a introdução da nova arquitetura no Brasil: 1925 a 1940. São Paulo: Museu de Arte de São Paulo, 1965.

FERREIRA, J. S. W. O mito da cidade global: o papel da ideologia na produção do espaço urbano. São Paulo: Vozes, 2007.

FIX, M. São Paulo cidade global: fundamentos financeiros de uma miragem. São Paulo: Boitempo, 2007.

FLORENZANO, Z. Condomínio e Incorporações: comentários à lei de estímulo à construção civil. Rio de Janeiro: Forense, 1966.

FOLHA ONLINE. Crise mundial gera perda de R\$ 871 bilhões na Bolsa brasileira. Folha Online, 29 de dezembro de 2008. Disponível em: <http://www1.folha.uol.com.br/folha/dinheiro/ult91u484204.shtml>. Acesso em: 5 maio 2011.

FONSECA, A. C. A Promoção Imobiliária Privada e a Construção da Cidade de São Paulo: 1970/2002. 2004. Tese (Doutorado)- Faculdade de Arquitetura e Urbanismo, Universidade de São Paulo, São Paulo, 2004.

FORTY, A. S., Pedro Maia (trad). Objetos de desejo: design e sociedade desde 1750. São Paulo: Cosac Naify, 2009.

FRANCO, R. E. D. Artacho Jurado: arquitetura proibida. São Paulo: Senac, 2008.

FUNDAÇÃO JOÃO PINHEIRO. Déficit habitacional no Brasil 2007. Brasília: Secretaria Nacional de Habitação, 2009.

G1. Construtoras brasileiras têm 7 dos 10 maiores lucros das Américas em 2010. G1, 6 de abril de 2010. Disponível em: http://g1.globo.com/economia/negocios/noticia/2011/04/construtoras-brasileiras-tem-maioreslucros-das-americas-em-2010.html. Acesso em: 5 maio 2011. 
GANDRA, A. Treze anos depois, Caixa volta a fornecer crédito mais barato para imóvel de classe média. Agência Brasil, 16 Novembro de 2005. Disponível em: <http://agenciabrasil.ebc.com.br/noticia/2005-11-16/trezeanos-depois-caixa-volta-fornecer-credito-mais-barato-para-imovel-de-classe-media>. Acesso em 30 ago. 2012.

GAVIÃO, M. M. F. Muito além do pavimento térreo: as áreas de lazer no mercado imobiliário em São Paulo. 2012. Dissertação (Mestrado) - Faculdade de Arquitetura e Urbanismo, Universidade de São Paulo, São Paulo, 2012.

GOVERNO FEDERAL. Manual Minha Casa Minha Vida. Brasília, DF. 2009.

GROPIUS, Walter. Bauhaus: novarquitetura. 5. ed. São Paulo: Perspectiva, 1997.

HEPNER, A. Desenho urbano, capital e ideologia em São Paulo: centralidade e forma urbana na marginal do rio pinheiros. 2010. Dissertação (Mestrado) - Faculdade de Arquitetura e Urbanismo, Universidade de São Paulo, São Paulo, 2010.

IBGE. Censo Demográfico 2000. Disponível em <http://www.ibge.gov.br/>. Acesso em 30 ago. 2012.

IBGE. Resultados preliminares da amostra do Censo Demográfico 2010. Disponível em <http://www.ibge.gov.br/>. Acesso em 30 ago. 2012.

JACOB, J. KAPLAN, L.B. The components of perceived risks. In: proceedings of the third Annual conference of the association for consumer research, p. 382-393, 1972.

KOTLER, Philip. Administração de Marketing. 10a edição. São Paulo: Prentice Hall, 2000.

LEFEVBRE, H. La production de l'espace. Paris: Éditions Anthopos,, 2000.

LEITE, L. R. P. Estudo das estratégias das empresas incorporadoras do município de São Paulo no segmento residencial no período 1960-1980. 2006. Dissertação (Mestrado) - Faculdade de Arquitetura e Urbanismo, Universidade de São Paulo, São Paulo, 2006.

LEVI, Rino. “Um prédio de apartamentos”. In Revista Politécnica, n. 120, jul. São Paulo, 1935.

LEVI, Rino. “Prédio de habitação do tipo semi-intensivo". In Revista Politécnica, n. 119, mar./jun. São Paulo, 1935.

MACEDO, S. S. Quadro do Paisagismo no Brasil. São Paulo: FAUUSP:Banco ITAÚ, 1999. 
MACEDO, S. S. São Paulo, paisagem e habitação verticalizada: os espaços livres como elementos de desenho urbano. 1988.Tese (Doutorado)- Faculdade de Arquitetura e Urbanismo, Universidade de São Paulo, São Paulo, 1988.

MANDL, C. Megainvestidor paga R\$ 135 milhões por 32\% da Gafisa. Valor Econômico, 10 de Maio de 2005. Disponível em: <http://noticias.uol.com.br/economia/ultnot/valor/2005/06/10/ult1913u31206.jhtm>. Acesso em: 5 maio 2011.

MARICATO, E. A produção capitalista da casa (e da cidade). São Paulo: Alfa-Omega, 1979.

MARINHO, E.; LINHARES, F.; CAMPELO, G. Os programas de transferência de renda do governo impactam a pobreza no Brasil?. Rev. Bras. Econ., Rio de Janeiro, v. 65, n. 3, set. $2011 . \quad$ Disponível <http://www scielo.br/scielo.php?script=sci \&lng=en\&nrm=iso>. Acesso em 30 ago. 2012.

MARTINS, Maria Lucia Refinetti. São Paulo, centro e periferia: a retórica ambiental e os limites da política urbana. Estud. av. [online]. 2011, vol.25, n.71 [cited 2013-02-24], pp. 59-72 . Disponível em: $<$ http://www.scielo.br/scielo.php?script=sci_arttext\&pid=S0103$40142011000100005 \&$ Ing=en\&nrm=iso>. Acesso em 30 ago. 2012.

MEYER, J. F. P. Demanda residencial: adequação da análise de mercado imobiliário, o caso de São Paulo. 2008. Tese (Doutorado) - Faculdade de Arquitetura e Urbanismo, Universidade de São Paulo, 2008.

MEYER, R. M. P. O espaço da vida coletiva. In Os centros das metrópoles: reflexões e propostas ara acidade democrática do século XXI. São Paulo: Editora Terceiro Nome: Viva o Centro: Imprensa Oficial do Estado, 2001.

MEYER, R. M. P.,GROSTEIN, M. D. \& BIDERMAN, C. São Paulo Metrópole. São Paulo: Imprensa Oficial do Estado de São Paulo, 2004.

MEYER, R. M. P. \& GROSTEIN, M. D. A Leste do Centro: territórios do urbanismo. São Paulo: Imprensa Oficial do Estado de São Paulo, São Paulo, 2010.

MEYER, R. M. P. O papel da rua na urbanização paulistana. In: Cadernos de história de São Paulo. Museu Paulista da Universidade de São Paulo. № 2, (jan-dez), 1993.

MILES, Mike E. Berens, Gayle. Weiss, Marc A. Real estate development: principles and process. 4.ed. Washington, D.C.: Urban Land Institute, 2007. 
MOURA, C. P. Ilhas urbanas: novas visões do paraíso. 2003. Tese (Doutorado) - Faculdade de Arquitetura e Urbanismo, Universidade Federal do Rio de Janeiro, 2003.

MOOS, Stanislaus von. Le Corbusier: elements of a synthesis. Boston, USA: The MIT Press, 1982.

MULDER, A. \& BROUWER, J. Transurbanism. Rotterdam: V2_Publishing/NAi Publishers, 2002.

NEGRI, B. Concentração e desconcentração industrial em São Paulo: 1880-1990. Campinas, SP: Editora da UNICAMP, 1996.

NERI, M. De volta para o país do futuro: crise européia, projeções e a nova classe média. Rio de Janeiro: FGV/CPS, 2012.

PEREIRA, P. C. X. . A reestruturação imobiliária em São Paulo como chave para o desvendamento da metrópole atual. In: ALESSANDRI CARLOS, A. F.; DE OLIVEIRA, A. U. (Org.). São Paulo 450 anos: geografia das metrópoles. São Paulo: Contexto, 2006.

PEREIRA, P. C. X. Reestruturação imobiliária em São Paulo (SP): especificidade e tendência. In: SILVEIRA, R. L. L. \& PEREIRA, P. C. X. \& UEDA. V. (org.) Dinâmica imobiliária e reestruturação urbana na América Latina. Santa Cruz do Sul: EDUNISC, 2006.

REIS, N. G. Notas sobre urbanização dispersa e novas formas de tecido urbano. São Paulo: Via das Artes, 2006.

ROLNIK, R. A cidade e a lei: legislação, política urbana e territórios na cidade de São Paulo. 3 ed. São Paulo: Studio Nobel, 2003.

SALGADO, Ivone. Caracterização dos promotores imobiliários que atuam na cidade de São Paulo : 1977 - 1982 . In: Espaço e Debates. no 21, 1987.

SAMPAIO, S. S. Indústria e território em São Paulo: a estruturação do multicomplexo territorial industrial paulista 1950/2005. São Paulo: Alínea, 2009.

SANTOS, C. H. M. Políticas federais de habitação no Brasil: 1964/1998. Brasilia: IPEA/ texto para discussão no 654 1999.

SANTOS, Milton. A urbanização brasileira. São Paulo: Edusp, 2008.

SCHERER, Rebeca (intr). Carta de atenas. São Paulo, HUCITEC: Edusp, 1986.

SEGAWA, Hugo. Arquiteturas no Brasil: 1900-1990. 2.ed. São Paulo: Edusp, 1999. 
SIMONSEN, M. H. Poupança e crescimento econômico: o caso brasileiro. In Ensaios Econômicos, n.178. Rio de Janeiro: EPGE, 1991.

SOUZA, M. A. A. de. A identidade da metrópole. São Paulo: HUCITEC; EDUSP, 1994.

SMOLKA, M. O. O Capital Incorporador e seus movimentos de valorização. Cadernos do IPPUR. UFRJ, Rio de Janeiro, 1 (3): 41-77, 1987.

SMOLKA, M. \& BIDERMAN, C. Housing informality: an economist's perspective on urban planning. In Handbook of Urban Economic and Planning, Oxford University Press, New York, pp.1-14. 2010

SOMEKH, Nadia. A cidade vertical e o urbanismo modernizador: São Paulo 1920-1939. 1994. Tese (Doutorado) Faculdade de Arquitetura e Urbanismo, Universidade de São Paulo, 1994.

SOWELL, T. The Housing Boom and Bust. Ed. Rev. Princeton: Basic Books; First Trade Paper Edition, 2010.

TAKIYA, H. Atlas ambiental do município de São Paulo. São Paulo; SMMA, 2002. Disponível em: $<$ http://atlasambiental.prefeitura.sp.gov.br/conteudo/cobertura_vegetal/veg_apres_02.pdf>. Acesso em 02/10/2012.

TARALLI, Cibele H. Ambiente construído e legislação: o visível e o imprevisível. 1993. Tese (Doutorado) - Faculdade de Arquitetura e Urbanismo, Universidade de São Paulo, 1993.

UN-HABITAT. Housing finance mechanisms in Brazil. Nairobi: UN-HABITAT, 2010.

VALOR ECONÔMICO. A nova onda imobiliária. Valor Econômico, 7 de fevereiro de 2006. Disponível em: <http://artigos.netsaber.com.br/resumo_artigo_30500/artigo_sobre_a_nova_onda_imobiliaria>. Acesso em 30 ago. 2012

VALOR ONLINE. Ex-vedete, segmento de baixa renda perdeu espaço no fim de 2010. Valor Online, 23 de março de 2011. Disponível em: http://www.valoronline.com.br/impresso/empresas/102/403663/ex-vedetesegmento-de-baixa-renda-perdeu-espaco-no-fim-de-2010>. Acesso em: 5 maio 2011.

VEDROSSI, A. O. A estrutura de Funding das Incorporadoras Imobiliárias após as ofertas públicas de ações. Revista construção e Mercado. Ed. Pini. Dezembro de 2008.

VEDROSSI, et all. O cenário pós-abertura de capital - Eficiência, eficácia e consolidação do mercado de real estate brasileiro na conjuntura do ciclo pós-IPOs. In: Notas reunião junho de 2010. Núcleo de Real Estate da Poli, 2010. Disponível em: <http://www.realestate.br/images/File/Comite/CM-Nota-240610.pdf> Acesso em 02 de outubro de 2012. 
VILLAÇA, Flávio. Espaço Intra-urbano no Brasil. São Paulo: Studio Nobel Editora, 1998.

TEIXEIRA, C. M. O condomínio absoluto. Belo Horizonte: C/Arte, 2009. 192p.

TOPALOV, C. Les promoteurs immobiliers: contribution à l'analyse de la production capitaliste du logement en France. Paris, Mouton, 1974.

Wiziack, J. Setor de construção civil começa a demitir. Folha Online, 06 de Novembro de 2008. Disponível em: <http://www1.folha.uol.com.br/folha/dinheiro/ult91u464816.shtml>. Acesso em: 5 maio 2011.

\section{LEGISLAÇÃO}

BRASIL. Lei federal n. 10.257, de 10 de julho de 2001. Estatuto da Cidade

BRASIL. Lei no 5.107 - de 13 de setembro de 1966.

Cria o fundo de garantia do tempo de serviço, e dá outras providências.

BRASIL. Lei 4.380, de 21 de março de 1964.

Criou o Sistema Financeiro da Habitação.

BRASIL. Lei no 4.591, de 16 de dezembro de 1964.

Dispõe sobre o condomínio em edificações e as incorporações imobiliárias.

BRASIL. Lei $n$ ㅇ 4.771, de 15 de setembro de 1965.

Institui o novo Código Florestal.

BRASIL. LEI № 12.651, DE 25 de maio de 2012.

Revoga as Leis nos 4.771, de 15 de setembro de 1965.

BRASIL. Lei no 6.766, de 19 de dezembro de 1979.

Dispõe sobre o Parcelamento do Solo Urbano e dá outras Providências.

SÃO PAULO (Município). Código de Posturas. 1886.

SÃO PAULO (Estado). Código Sanitário Estadual. 1918.

SÃO PAULO (Município). Lei no 2611, de 20 de junho de 1923 
Primeira que disciplinou a abertura de loteamentos.

SÃO PAULO (Município). Lei no 3.427 de 19 de novembro de 1929.

Institui o Código de Obras.

SAO PAULO (Município). Lei 7.805 de 10 de novembro de 1972.

Dispõe sobre o parcelamento, uso e ocupação do solo do Município e dá outras providências.

SAO PAULO (Município). Lei no 8.001, de 24 de dezembro de 1973.

Dispõe sobre o uso e ocupação do solo urbano, altera e complementa a Lei no 7.805 , de 1ㅇ de novembro de 1972, e dá outras providências.

SAO PAULO (Município). Lei no 8.881, de 29 de março de 1979.

Altera e complementa dispositivos das Leis nos 8.266, de 20 de junho de 1975, 7.805, de 1 o de novembro de 1972, 8.001, de 24 de dezembro de 1973 e 8.328, de 2 de dezembro de 1975, e dá outras providências.

SAO PAULO (Município). Lei no 9413, de 30 de dezembro de 1981

Dispõe sobre parcelamento do solo Município de São Paulo, e dá outras providências.

SAO PAULO (Município). Lei no 13.430 de 13 de setembro de 2002.

Institui o Plano Diretor Estratégico e o Sistema de Planejamento e Gestão do Desenvolvimento Urbano do Município de São Paulo. São Paulo: Prefeitura do Município de São Paulo.

SAO PAULO (Município). Lei no 13.885, de 25 de agosto de 2004.

Estabelece normas complementares ao Plano Diretor Estratégico, institui os Planos

Regionais Estratégicos das Subprefeituras, dispõe sobre o parcelamento, disciplina e

ordena o Uso e Ocupação do Solo do Município de São Paulo.

SAO PAULO (Município). Decreto n.o 45.817, de 4 de abril de 2005

Dispõe sobre a classificação dos usos residenciais e não residenciais.

SAO PAULO (Município). Resolução no 105, de 03 de setembro de 2008.

Uso do Solo - Categorias de Uso. Orienta sobre usos mistos. 
SÃO BERNARDO DO CAMPO (Município). Lei no 5716 de 23 de agosto de 2007.

Dispõe sobre o uso e ocupação do solo para o. Município de São Bernardo do Campo.

SÃO BERNARDO DO CAMPO (Município). Lei no 5.593 de 05 de Outubro de 2006.

Aprova o Plano Diretor do Município de São Bernardo do Campo

GUARULHOS (Município). Lei no 6253, de 24 de maio de 2007.

Dispõe sobre o uso, a ocupação e o parcelamento do solo no Município de Guarulhos e dá providências correlatas.

GUARULHOS (Município). Lei no 6.055, de 30 de dezembro de 2004.

Regulamenta o Plano Diretor de Desenvolvimento Urbano, Econômico e Social do Município de Guarulhos. 